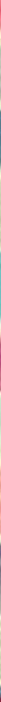

Routledge Research in Museum Studies

\title{
DIVERSITY AND \\ PHILANTHROPY AT AFRICAN \\ AMERICAN MUSEUMS
}

BLACK RENAISSANCE

Patricia A. Banks

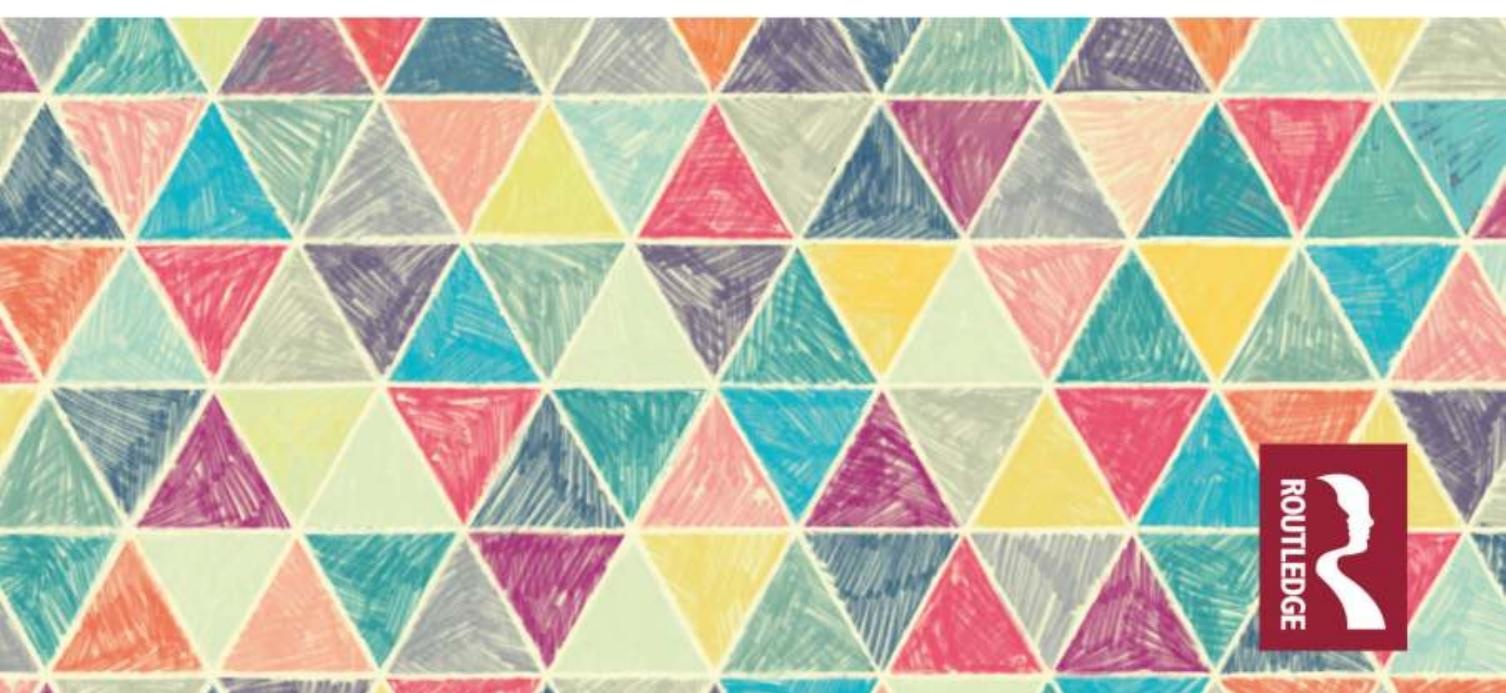




\section{Diversity and Philanthropy at African American Museums}

Diversity and Philanthropy at African American Museums is the first scholarly book to analyze contemporary African American museums from a multifaceted perspective. While it puts a spotlight on the issues and challenges related to racial politics that black museums collectively face in the $21 \mathrm{st}$ century, it also shines a light on how they intersect with corporate culture, youth culture, and the broader cultural world. Turning the lens to philanthropy in the contemporary era, Banks throws light on the establishment side of African American museums and demonstrates how this contrasts with their grassroots foundations.

Drawing on over 80 in-depth interviews with trustees and other supporters of African American museums across the United States, this book offers an inside look at the world of cultural philanthropy. While patrons are bound together by being among the distinct group of cultural philanthropists who support black museums, the motivations and meanings underlying their giving depart in both subtle and considerable ways depending on race and ethnicity, profession, generation, and lifestyle. Revealing not only why black museums matter in the eyes of supporters, the book also complicates the conventional view that social class drives giving to cultural nonprofits. It also paints a vivid portrait of how diversity colors cultural philanthropy, and philanthropy more broadly, in the 21 st century.

Diversity and Philanthropy at African American Museums will be a valuable resource for scholars and practitioners engaged with African American heritage. It will also offer important insights for academics, as well as cultural administrators, nonprofit leaders, and fundraisers who are concerned with philanthropy and diversity.

Patricia A. Banks is a sociologist of culture with a focus on the African diaspora. She is a 2018-2019 Mellon Fellow at CASBS at Stanford University, USA, and has previously been in residence as a Fellow at the Hutchins Center at Harvard University, USA. She is Associate Professor of Sociology at Mount Holyoke College, USA. 


\section{Routledge Research in Museum Studies}

19 Collecting and Exhibiting Computer-Based Technology

Expert Curation at the Museums of the Smithsonian Institution Petrina Foti

20 Biculturalism at New Zealand's National Museum An Ethnography of Te Papa

Tanja Schubert-McArthur

21 Museum Innovation and Social Entrepreneurship

A New Model for a Changing Era

Haitham Eid

22 Diversity and Philanthropy at African American Museums

Black Renaissance

Patricia Banks

23 The Private Collector's Museum

Public Good Versus Private Gain

Georgina Walker

24 Museums as Cultures of Copies

Edited by Brenna Brita

25 The Personalization of the Museum Visit

Art Museums, Discourse, and Visitors

Seph Rodney

www.routledge.com/Routledge-Research-in-Museum-Studies/book-series/ RRIMS 


\title{
Diversity and Philanthropy at African American Museums \\ Black Renaissance
}

\author{
Patricia A. Banks
}

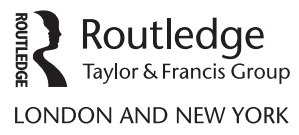


First published 2019

by Routledge

2 Park Square, Milton Park, Abingdon, Oxon OX14 4RN

and by Routledge

52 Vanderbilt Avenue, New York, NY 10017

Routledge is an imprint of the Taylor \& Francis Group, an informa business

(C) 2019 Patricia A. Banks

The right of Patricia A. Banks to be identified as author of this work has been asserted by her in accordance with sections 77 and 78 of the Copyright, Designs and Patents Act 1988.

All rights reserved. No part of this book may be reprinted or reproduced or utilised in any form or by any electronic, mechanical, or other means, now known or hereafter invented, including photocopying and recording, or in any information storage or retrieval system, without permission in writing from the publishers.

Trademark notice: Product or corporate names may be trademarks or registered trademarks, and are used only for identification and explanation without intent to infringe.

British Library Cataloguing-in-Publication Data

A catalogue record for this book is available from the British Library

Library of Congress Cataloging-in-Publication Data

A catalog record has been requested for this book

ISBN: 978-0-8153-4964-8 (hbk)

ISBN: 978-1-351-16436-8 (ebk)

Typeset in Sabon LT Std

by Newgen Publishing UK 
To my parents-Cherry A. McGee Banks and James A. Banks 



\section{Contents}

List of illustrations viii

Acknowledgments $\quad \mathrm{x}$

1 Diverse patrons, diverse values 1

2 African American/All-American 33

3 Doing well by doing good $\quad 82$

4 The connoisseur's eye 110

5 A new generation 145

6 Rethinking cultural patronage in a diverse age $\quad 174$

Appendix 1: African American museums:

Basic characteristics

192

Appendix 2: Methods 196

Index 200 


\section{Illustrations}

\section{Figures}

All figures by the author, unless otherwise indicated.

1.1 Oprah Winfrey (left), who donated over $\$ 20$ million to the National Museum of African American History and Culture, at the museum's opening ceremony, with the actor Will Smith (right). Leah L. Jones for the NMAAAHC

1.2 The television producer Shonda Rhymes (center), who donated \$10 million to the National Museum of African American History and Culture, at the museum's opening ceremony. Alana Donocoff for the NMAAAHC

1.3 Founding dates of African American Museums

1.4 National Museum of African American History and Culture, Washington, DC

1.5 Center for Civil and Human Rights, Atlanta, Georgia

1.6 The Studio Museum in Harlem, New York

1.7 Reginald F. Lewis Museum, Baltimore, Maryland

1.8 National Underground Railroad Freedom Center, Cincinnati, Ohio

1.9 Museum of the African Diaspora, San Francisco, California

2.1 Bill and Melinda Gates Foundation Concourse Atrium and Oprah Winfrey Theater, National Museum of African American History and Culture, Washington, DC

2.2 Mae's Millinery Exhibition, the National Museum of African American History and Culture

2.3 Photograph of Malcolm X (left) and Archbishop Iakovos of America (right) at the National Museum of African American History and Culture

3.1 Gift shop at the National Center for Civil and Human Rights, Atlanta, Georgia

4.1 Culture galleries in the National Museum of African American History and Culture 
5.1 The Millennial singer, rapper, and actress Janelle Monáe in a Black Girl Magic jacket at the opening ceremony for the National Museum of African American History and Culture. Leah L. Jones for the NMAAAHC

5.2 Protesters prepare to march in downtown St. Louis (Rahiel Tesfamariam, center, wearing a “This Ain't Yo Mama's Civil Rights Movement" t-shirt later donated to the National Museum of African American History and Culture). Rick Wilking

5.3 “This Ain't Yo Mama's Civil Rights Movement” t-shirt worn by Rahiel Tesfamariam at a protest commemorating Michael Brown. Collection of the Smithsonian National Museum of African American History and Culture, Gift of Rahiel Tesfamariam

5.4 Site of the assassination of Martin Luther King Jr., Lorraine Motel, National Civil Rights Museum, Memphis, Tennessee

5.5 Black Lives Matter t-shirts for sale at the Reginald F. Lewis Museum of Maryland African American History and Culture, Baltimore, Maryland

6.1 Lonnie Bunch, director of the National Museum of African American History and Culture, speaking at the Association of African American Museums annual meeting, 2017

6.2 Entrance to the International Slavery Museum, London, England

6.3 Opening of the Zeitz Museum of Contemporary Art Africa, Cape Town, South Africa

6.4 Entrance to the Apartheid Museum in Johannesburg, South Africa

\section{Tables}

1.1 Selected recent multimillion-dollar African American museum campaigns 


\section{Acknowledgments}

I am incredibly grateful to the museum patrons and staff who generously shared their thoughts and experiences about philanthropy with me. This research was moved forward by two sabbaticals and funding from Mount Holyoke College as well as insightful feedback from colleagues there. I was also fortunate to complete this book through funding and a residential Andrew W. Mellon Foundation Fellowship at the Center for Advanced Study in the Behavioral Sciences at Stanford University. Conversations with colleagues at the following conferences, workshops, and seminars were also tremendously beneficial: the "Blacks and African Americans: Exploring Memory, Affect and Segregation" session and a Consumers and Consumption session at the 2018 American Sociological Association Annual Meeting; the Class and Culture Mini-Conference at the 2018 Eastern Sociological Society Annual Meeting; a 2018 session of The B-Side podcast; the 2017 Fifth Exposure Seminar for The Dark Room: Race and Visual Culture Studies Faculty Seminar; the Elites Mini-Conference at the 2017 Eastern Sociological Society Annual Meeting; a session of the 2017 "Museums in Society" class at Smith College; the 2017 visit to the National Museum of African American History and Culture with the Smith College project "American History as African American History;" and, a session of the 2013 Northwestern Ethnography Workshop. Many thanks to staff at the Smithsonian Institution Archives, the Schomburg Center for Research in Black Culture, and the Northeastern University Archives \& Special Collections. I began to study cultural patronage and race while I was a graduate student at Harvard University. I continue to be grateful for the inspiration and support from my professors thereLawrence D. Bobo, William Julius Wilson, Michèle Lamont, and Prudence L. Carter. My sociological imagination was first sparked by Barbara Carter, Harry Lefever, Mona Phillips, Cynthia Spence, Bruce Wade, Darryl White, and my other professors at Spelman College. I also wish to express sincerest thanks to colleagues and mentors associated with the UNCF/Mellon Programs including Walter R. Allen, Cynthia Spence, and Sarah Susannah Willie-LeBreton. I am tremendously fortunate for the support of three other professors who also happen to be family-my father James A. Banks, my mother Cherry A. McGee Banks, and my sister Angela M. Banks. 


\section{Diverse patrons, diverse values}

It is around 10:00 a.m. on Saturday, September 24, 2016, and I am sitting on the grass by the Washington Monument for the dedication ceremony of the National Museum of African American History and Culture (NMAAHC). A gray overcast sky frames the jumbotron in the middle of the field that is broadcasting from the main stage. Between a speech by Mayor Muriel Bowser of Washington, DC, and a musical set by the African singer Angélique Kidjo, the screen flashes facts about the museum and inspiring words about the struggle for racial equality. While the quotations, including excerpts from Sam Cooke's song “A Change Is Gonna Come" (1964), speak to the unyielding spirit that guided the century-long effort to bring this museum into reality, ${ }^{1}$ the names of major donors projected onto the screen, such as the media mogul Oprah Winfrey, the basketball star Michael Jordan, the tech entrepreneur Bill Gates, and the television producer Shonda Rhimes are a reminder of the philanthropists who made the museum possible (see Figures 1.1 and 1.2).

Philanthropy is not only partly responsible for the establishment of the NMAAHC, it also undergirds the broader black museum renaissance during which hundreds of African American museums have opened across the United States since the 1960s and 1970s. ${ }^{2}$ While patrons are arguably the backbone of this museum boom, the motivations and meanings that surround their philanthropy are largely unknown. Drawing on more than 80 in-depth interviews with trustees and other patrons of black museums in 11 cities, as well as archival records, and firsthand observations, I provide an inside view of the philanthropy that fuels this renaissance. I find that though supporters share membership in the upper-middle and upper class, their philanthropic values vary in both subtle and considerable ways depending on race, generation, profession, and lifestyle.

Black and white patrons alike stand firm that African American museums are truly American museums. However, while the former are often especially conscious of the importance of African American museums within the black community, the latter are typically more cognizant about the roles that they play in the lives of whites. Supporters who work in business often 


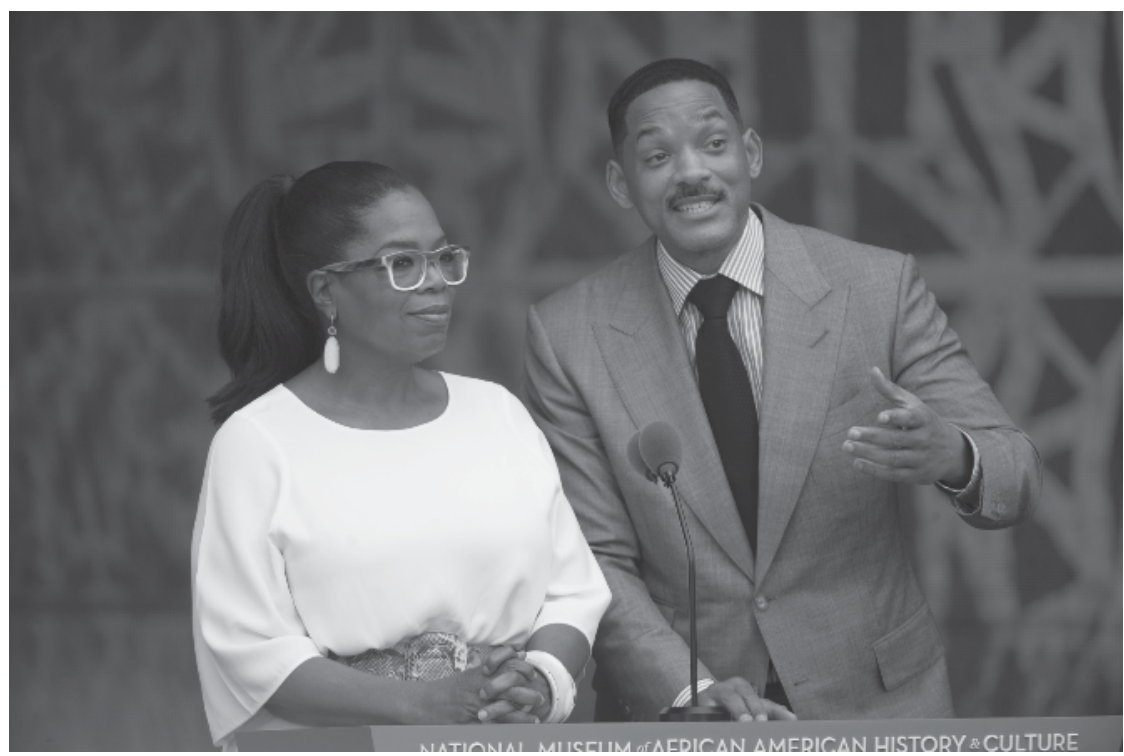

Figure 1.1 Oprah Winfrey (left), who donated over \$20 million to the National Museum of African American History and Culture, at the museum's opening ceremony, with the actor Will Smith (right). Leah L. Jones for the NMAAAHC.

view black museum philanthropy as a means to not only "do good" but also "do well" through promoting their careers, while supporters who work in other sectors are less likely to view giving as having direct professional benefits. Cultural connoisseurs typically see art and history as the lifeblood of black museums, yet cultural appreciators are often less interested in black museums as purely cultural institutions. And, although supporters across the generations share a concern with positioning African American museums as 21st-century institutions, it is often Generation Xers and Millennials who are the most committed to a focus on contemporary culture, politics, and technology.

In Diversity and Philanthropy at African American Museums one of my primary goals is to richly describe how these various types of supporters define the worth of black museums in assorted ways. However, my analysis also advances research and perspective on a much broader issue: museums and diversity. A common view of museum patronage is that it is ordered around a class divide between the lower and upper classes-or, that museums and other cultural institutions are the domain of the elite (Alexander 1996b; Bourdieu, Darbel, and Schnapper 1991; DiMaggio 1982a, 1982b; Ostrower 1999, 43-53, 2002). ${ }^{3}$ What gets lost in classcentric theories of museums is that there is a plurality of cultural values 


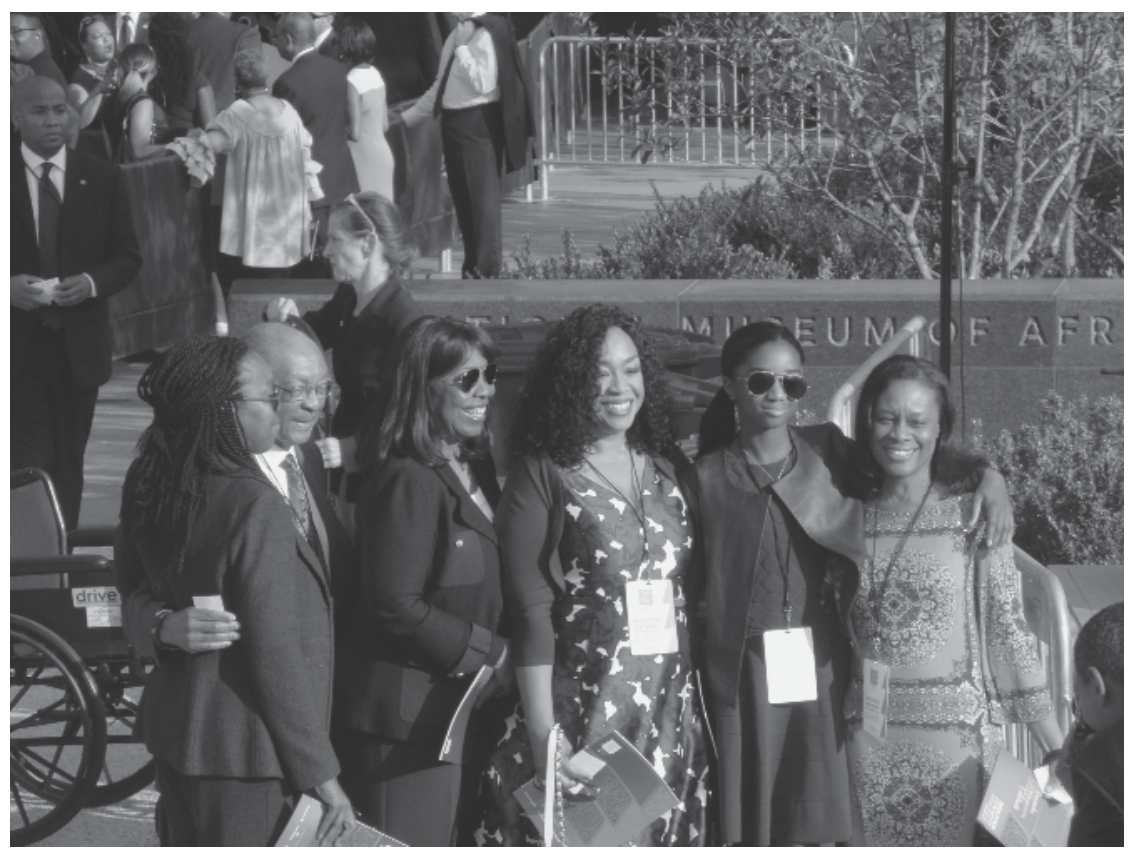

Figure 1.2 The television producer Shonda Rhymes (center), who donated $\$ 10$ million to the National Museum of African American History and Culture, at the museum's opening ceremony. Alana Donocoff for the NMAAAHC.

among the upper-middle and upper class. By elaborating how subgroups within the upper-middle- and upper-class value black museums in distinct ways, Diversity and Philanthropy at African American Museums sheds light on the intraclass divisions that mark museum patronage. It also offers new theoretical insights on the interconnections between social boundaries and cultural participation more broadly. Before delving into the world of philanthropy at black museums, it will be helpful to understand their trajectory of growth. In the next section, I provide an overview of the development of the field of black museums.

\section{The boom}

The earliest collections of black culture and history in the United States trace back to the 19 th and early 20th centuries. During this period, museums were founded on the campuses of Historically Black Colleges and Universities (HBCUs) such as Hampton and Howard Universities; historical societies were established, such as the Bethel Literary and Historical Association at the African Methodist Episcopal Church in Philadelphia, Pennsylvania; and 
cultural organizations, such as the Division of Negro Literature, History and Prints at the New York Public Library, opened. However, it was from the 1950s through the 1970s that the seeds of the black museum movement were planted. The black museum movement's political and cultural foundations were grounded in the civil rights, Black Power, and Black Arts movements (Ardali 1989, 1-73; Burns 2013; Fleming 2018; Mack and Welch 2018). The calls for black equality, self-determination, and cultural empowerment during this period were institutionalized through the founding of black museums.

The first museums established during this era were modest storefronts (Burns 2013). Museums in this storefront period often had meager budgets, volunteer staff, unassuming buildings, and informal acquisitions and exhibitions programs. For example, when the DuSable Museum of African American History (Chicago, Illinois) was founded by Margaret Burroughs in 1961, it was housed in an old mansion where her family lived, and it was maintained by an all-volunteer staff (Feldman 1981). Similarly, when the Charles H. Wright Museum of African American History was founded in 1965 , it was a grassroots affair that was housed in the founder's apartment (Burns 2013, 64). Although some museums, such as the African American Museum in Philadelphia founded in 1976, had grander beginnings (Dickerson 1989), even these were relatively small-scale institutions in comparison with what was to come in the next several decades. ${ }^{4}$ Over time, the field itself became more professionalized with the establishment of the Association of African American Museums (AAAM) in 1978 (African American Museums Association 1988, ix). The number of museums also swelled, and the scale of museums themselves shifted "from storefronts to monuments" (Burns 2013).

There were a dozen or so African American museums in the 1960s, but by the 1980s the number had reached close to 100 , and at the dawn of the 21st century they numbered around 230 (African American Museums Association 1988, 3; Austin 2003, iv). ${ }^{5}$ By 2016, there were more than 300 African American museums and related cultural institutions across the United States (see Figure 1.3). ${ }^{6}$ Although many are still best characterized as storefronts, there exists a critical mass of larger African American museums (see Figures 1.4-1.9). ${ }^{7}$ Over time, as the field matured, the number of museums ballooned, and so did the ambitions of their founders. Some African American museums established since the 1990s boast awardwinning buildings designed by famous architects, staff across a variety of organizational units, diverse collections with valorized objects, endowments, and multimillion-dollar campaigns to pay for it all. For example, in 2004 the \$110 million National Underground Railroad Freedom Center opened in Cincinnati, Ohio. The architects for the 158,000-square-foot building were chosen after a national design competition. Well-known figures in political life, such as Laura Bush, and celebrities, such as Oprah Winfrey, ${ }^{8}$ also attended the groundbreaking ceremony. The next year, in 2005, the 


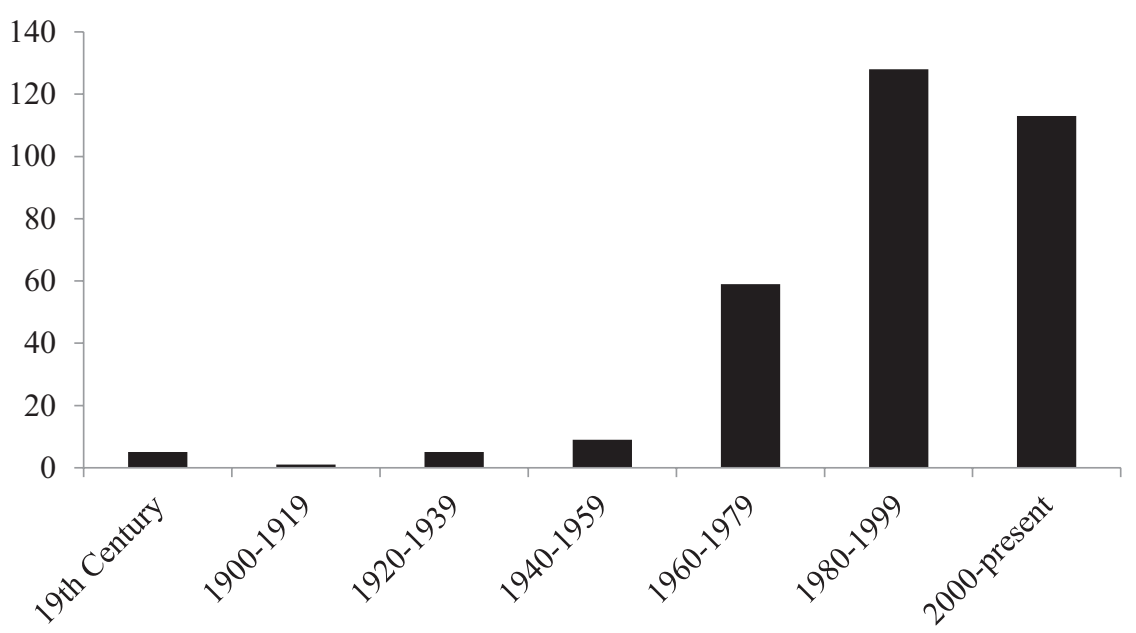

Figure 1.3 Founding dates of African American Museums.

\$34 million Reginald F. Lewis Museum of Maryland African American History and Culture opened in Baltimore. After the Reginald F. Lewis Foundation donated $\$ 5$ million to the effort, the museum was named after the deceased black business pioneer, who was born in the city. The 82,000-square-foot museum houses a gift shop, café, classrooms, and theater. Its architects, the celebrated Freelon Group (Edsall 2005), are also notable in that they are among the architects of choice for other monumental African American museums. The firm also worked on museums such as the $\$ 125$ million Center for Civil and Human Rights in Atlanta and the over $\$ 500$ million NMAAHC. The architecture firm Perkins and Will, which merged with the Freelon Group in 2014, designed Pittsburgh's multimilliondollar August Wilson Center for African American Culture and won a 2010 American Institute of Architects (AIA) award soon after the building opened.

The NMAAHC arguably represents the apotheosis of the black museum movement and the even longer efforts rooted in the 19th century to nationally institutionalize black culture and history. It is the monumental black museum super-sized. The distinct building was designed by celebrated architects (not only the Freelon Group but also the British "starchitect" David Adjaye). It has a world-class collection with 34,000 artifacts, a theater, educational space, a family resource center, and a restaurant led by the chef and television star Carla Hall. This era of the African American museum movement continues with multimillion-dollar fundraising efforts underway to build museums such as the International African American Museum in South Carolina, and major campaigns to upgrade existing museums such as the Motown Museum in Detroit, Michigan, and the Studio Museum in Harlem (SMH) (see Table 1.1). There are also proposals to 


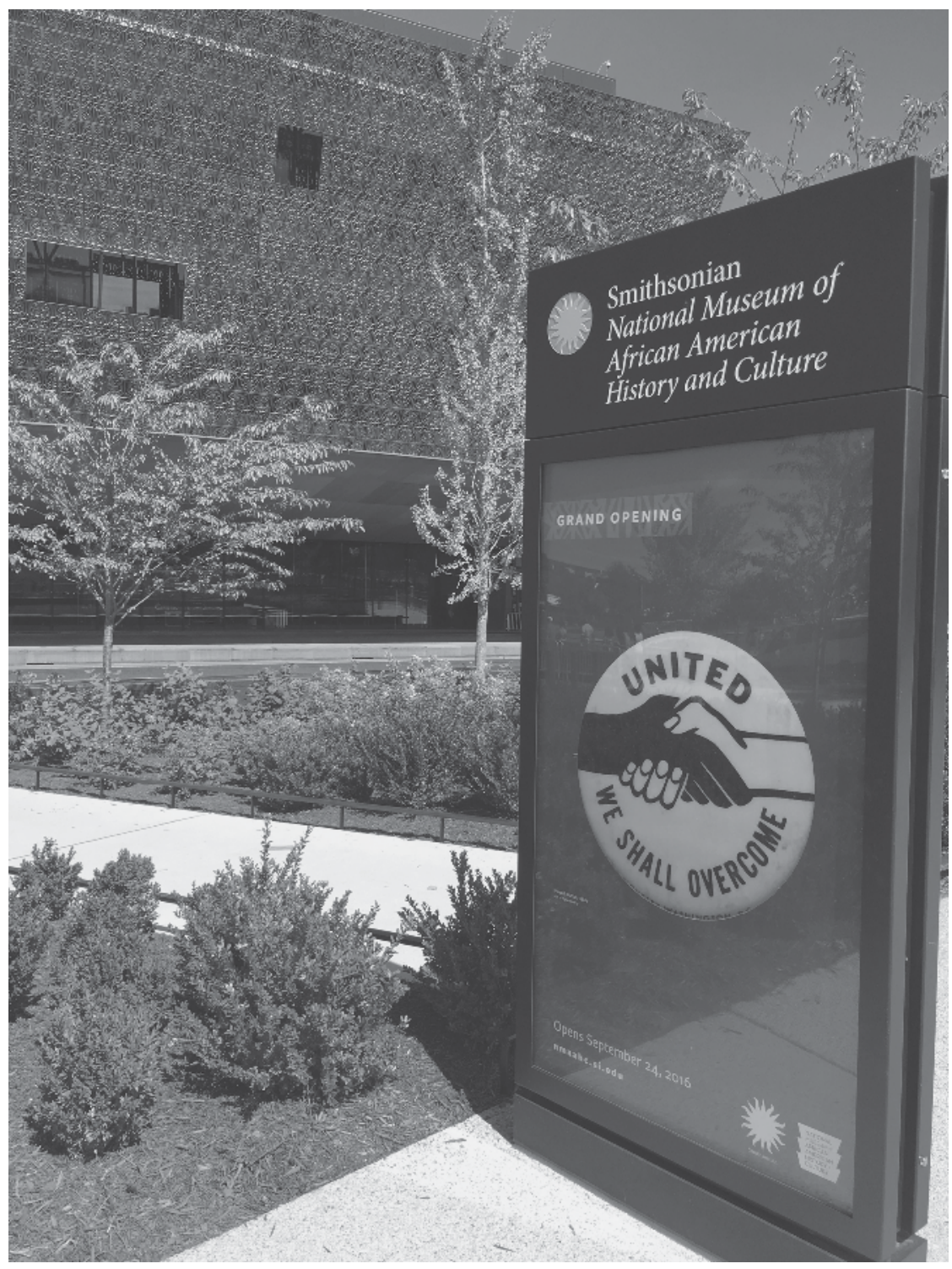

Figure 1.4 National Museum of African American History and Culture, Washington, DC.

build new black museums in states such as Florida, Georgia, and California (Harris 2018; McMorris 2018; Prabhu 2018).

Just as this has been the era of the big African American museum, it has also been a period during which several institutions have been riddled with severe financial crises. Some, such as the \$100 million United States National 


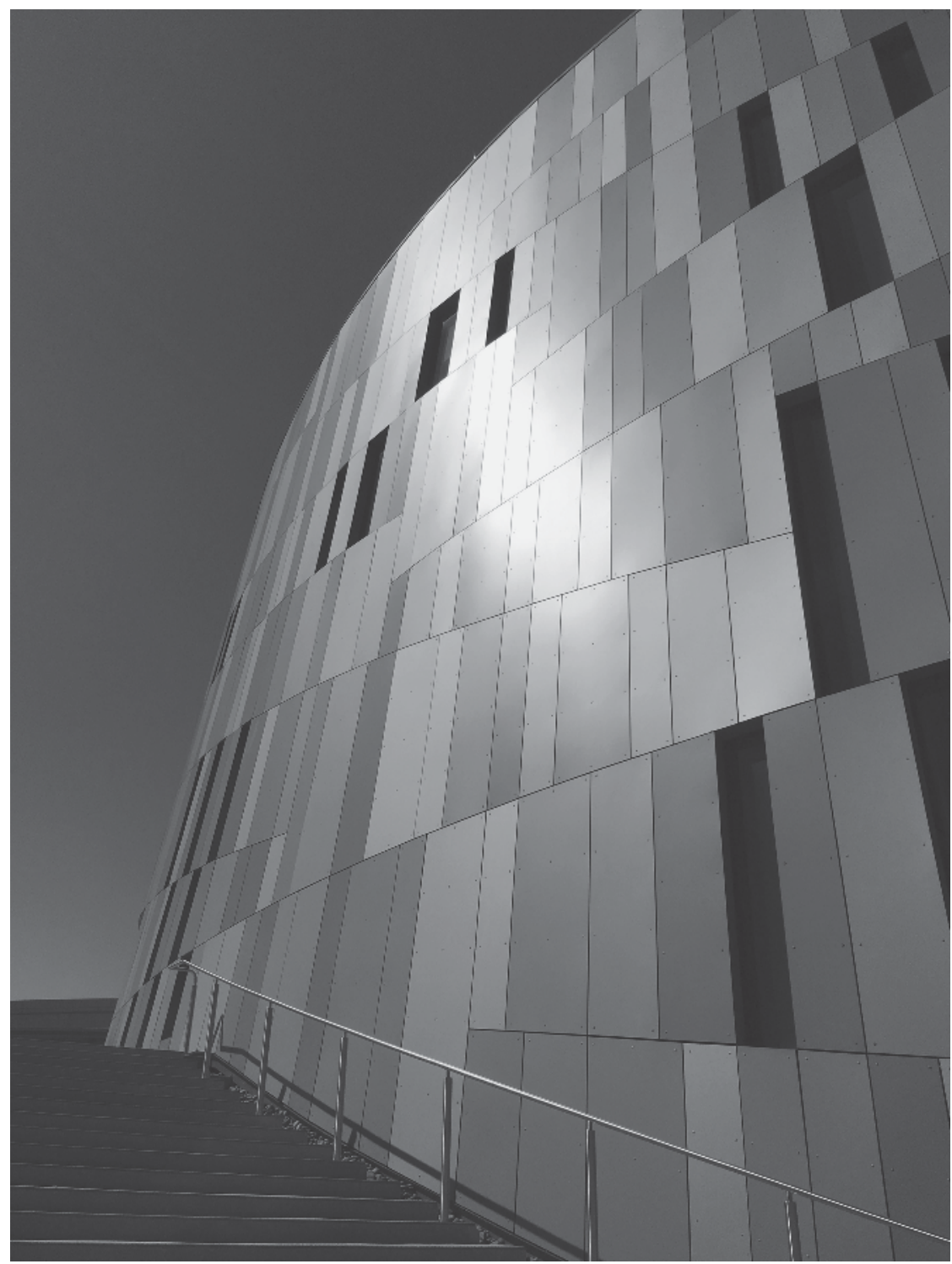

Figure 1.5 Center for Civil and Human Rights, Atlanta, Georgia.

Slavery Museum still have not gotten off the ground despite years of efforts (Manly 2016). Others had noteworthy capital campaigns yet quickly ran into financial challenges after opening. For example, soon after the National Underground Railroad Freedom Center opened, it faced a \$5.5 million deficit (Post Staff Report 2007). Similarly, four years after the August Wilson Center in Pittsburgh, Pennsylvania, opened to wide acclaim in 2009, it went 


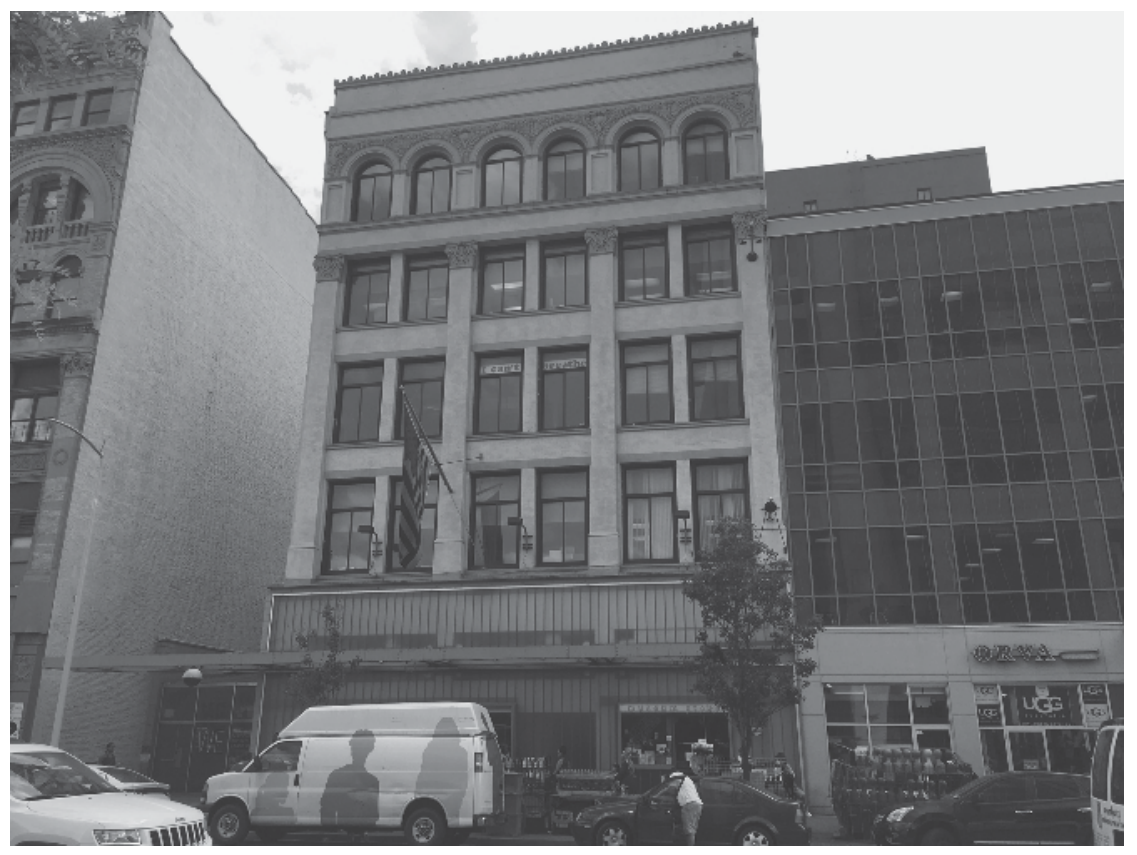

Figure 1.6 The Studio Museum in Harlem, New York.

into bankruptcy and closed. It reopened in 2014 after foundations in the city formed a consortium to raise funds and purchase the center (O'Toole 2015). Even old guard museums like the Charles H. Wright Museum of African American History have faced financial difficulties. In 2004, the Detroit institution needed emergency funding from the city to remain open (Montagne 2004).

These financial challenges emerge partly because the adage "If you build it, they will come" is not always realized. Some monumental museums attract donors to pay for multimillion-dollar start-up costs but cannot retain them to help pay for costly operating expenses. Ongoing philanthropy is necessary after buildings go up. Commenting on the continuing need for private funds, Lonnie Bunch, founding director of the NMAAHC, notes, "We need money for an endowment because the federal money is uncertain" (Trescott and Freedom du Lac 2012). ${ }^{9}$ When existing African American museums undergo renovations, the costs to run them can also increase. ${ }^{10}$ For example, to help prepare for the rising operating costs that are expected to accompany the Studio Museum in Harlem's \$175 million makeover, the organization's advancement infrastructure is being expanded. ${ }^{11}$

As it has been in other periods of cultural flowering, philanthropy is one driver of the black museum renaissance. Patrons provide the economic, cultural, social, and other forms of capital to establish and sustain these 


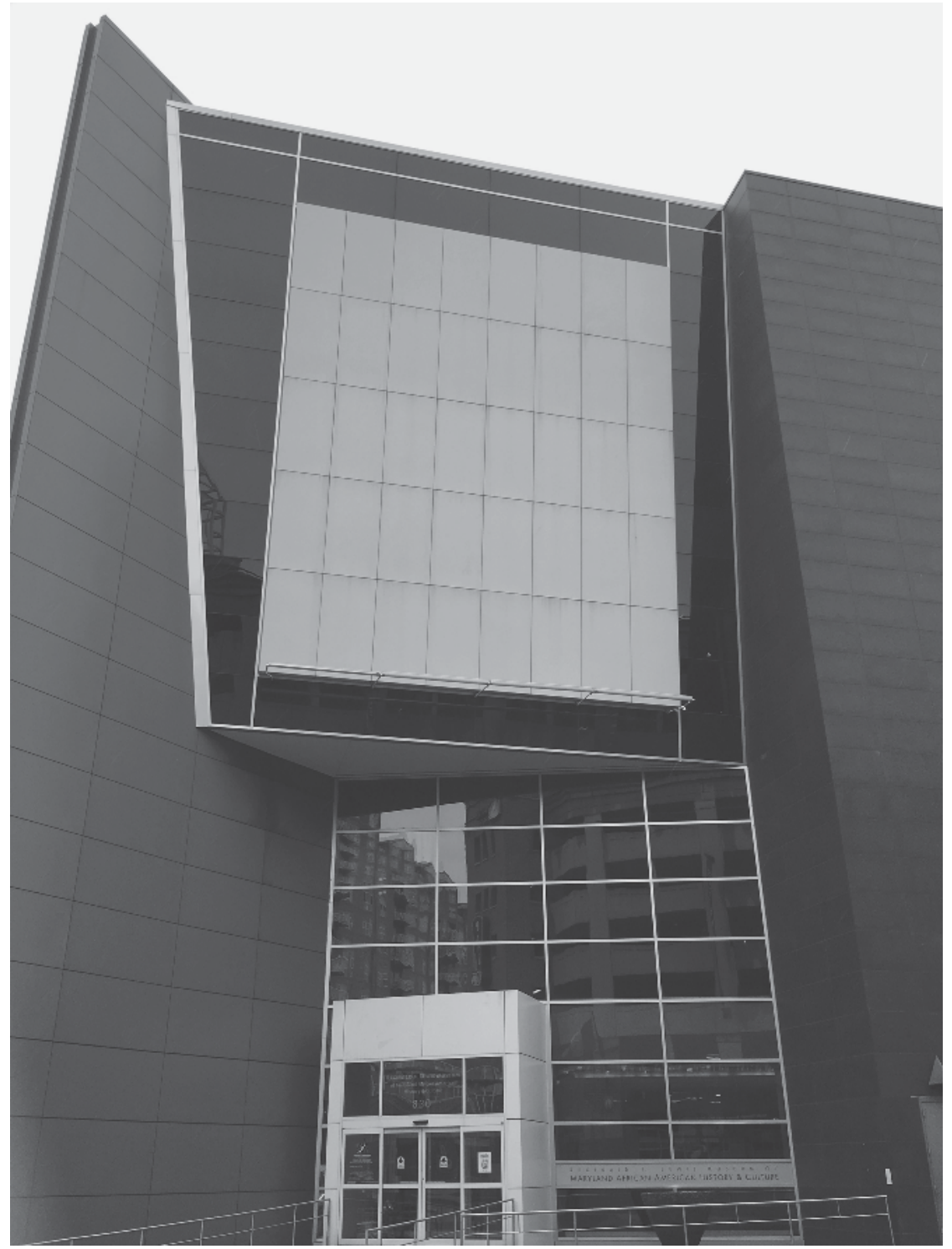

Figure 1.7 Reginald F. Lewis Museum, Baltimore, Maryland.

institutions. Understanding the meanings and motivations underlying their philanthropy can help us gain both insight into the development of this field of museums and broader perspective on social boundaries and cultural patronage. This line of inquiry can also offer practical insights that are important for the sustainability of black museums. ${ }^{12}$ 


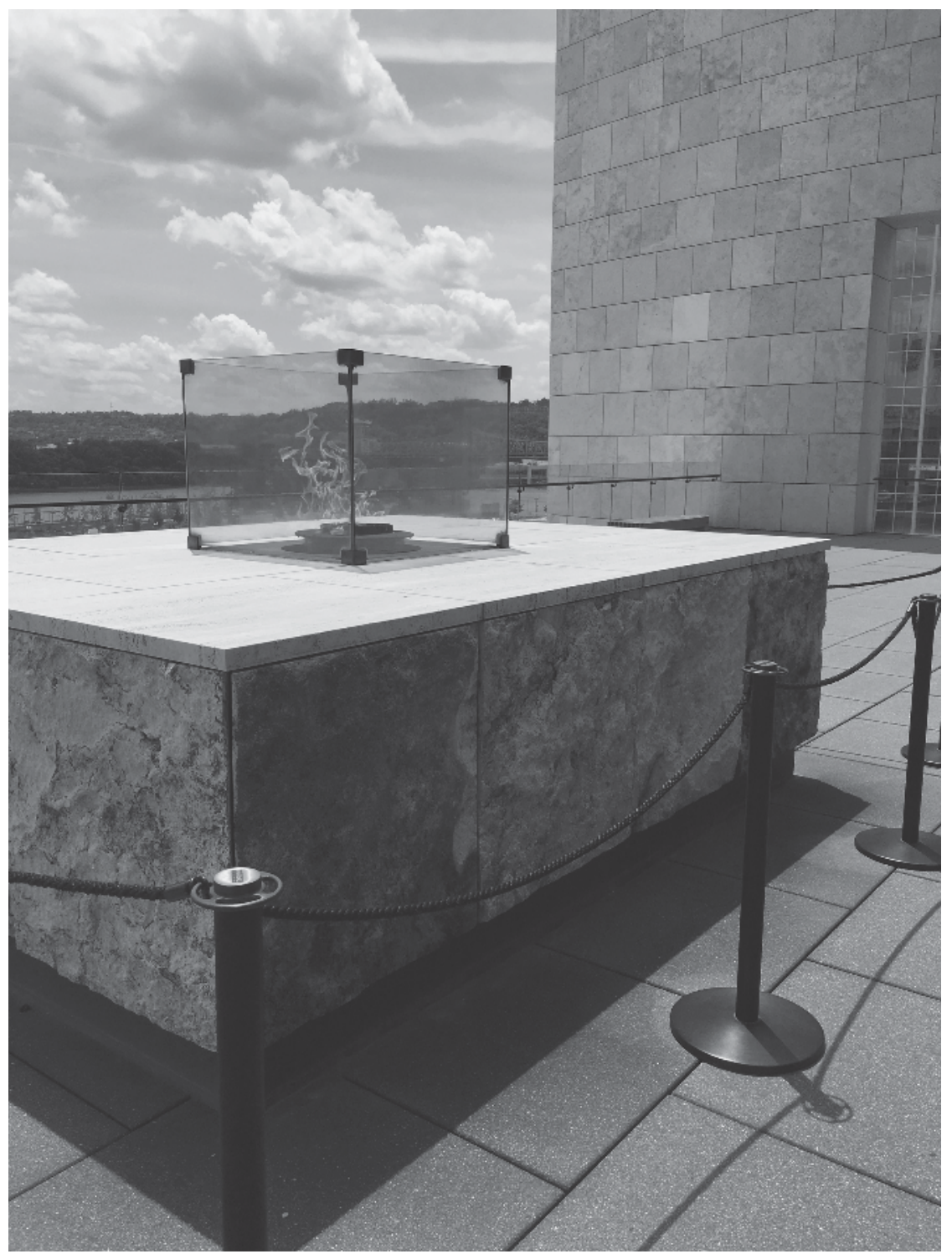

Figure 1.8 National Underground Railroad Freedom Center, Cincinnati, Ohio.

\section{Patrons and museums}

To understand patronage at African American museums, I draw on in-depth interviews with 84 supporters, participant observation at museums, and archival documents related to giving. ${ }^{13}$ Most supporters are trustees, with 


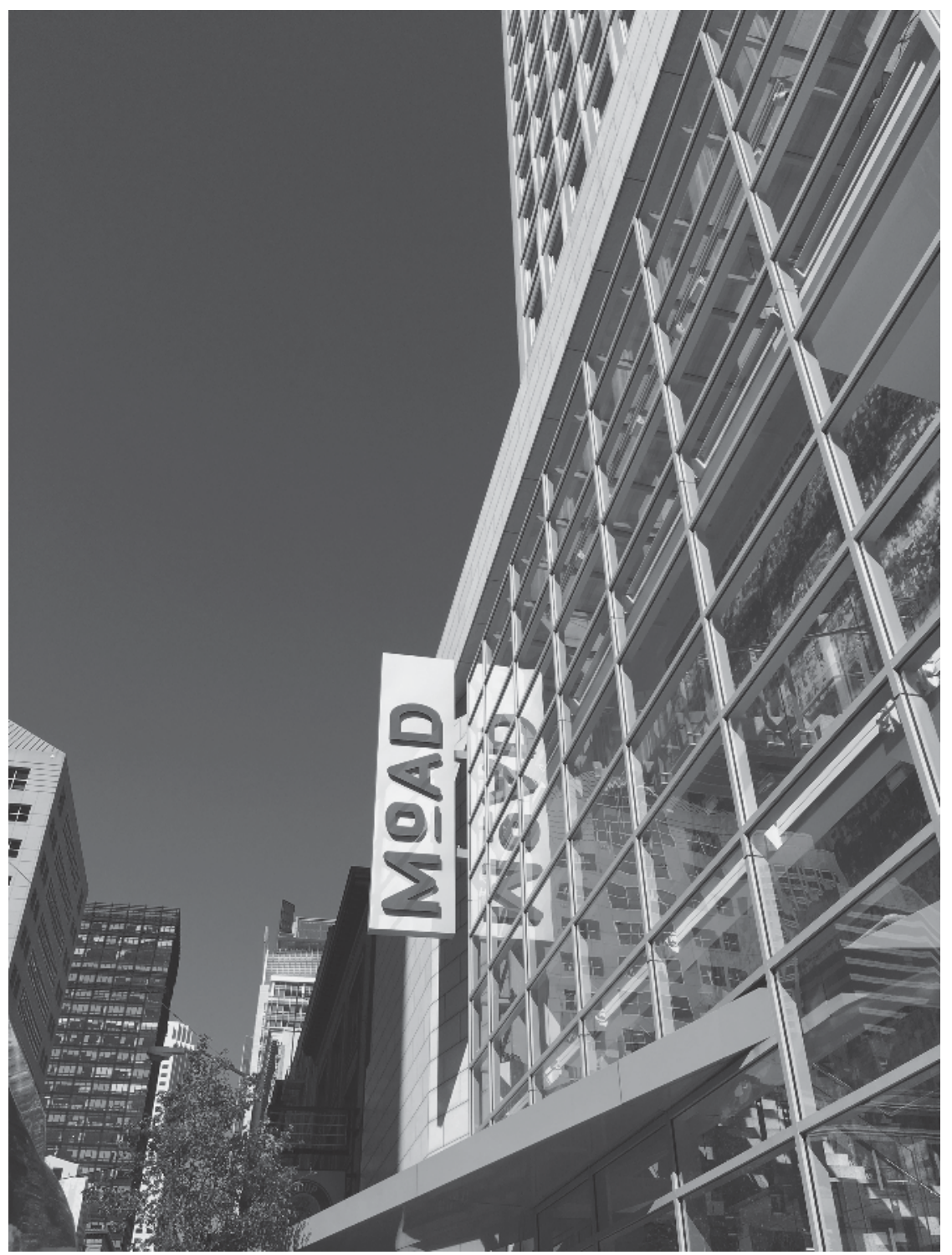

Figure 1.9 Museum of the African Diaspora, San Francisco, California.

the remaining mainly members of committees or friends groups. I identified the majority of participants from publicly available lists of supporters such as annual reports. The semistructured interviews typically took place in participants' offices, though in some cases I also met them in other places, such as museums, homes, and restaurants. Most often the interviews began 


\section{Diverse patrons, diverse values}

Table 1.1 Selected recent multimillion-dollar African American museum campaigns

\begin{tabular}{|c|c|c|c|}
\hline Name & Place & Purpose & $\begin{array}{l}\text { Fundraising } \\
\text { goal }\end{array}$ \\
\hline $\begin{array}{l}\text { African American } \\
\text { Cultural Heritage } \\
\text { Action Fund }\end{array}$ & $\mathrm{n} / \mathrm{a}$ & $\begin{array}{l}\text { preservation } \\
\text { projects }\end{array}$ & $\$ 25,000,000$ \\
\hline $\begin{array}{l}\text { African American } \\
\text { Museum in } \\
\text { Philadelphia }\end{array}$ & $\begin{array}{l}\text { Philadelphia, } \\
\text { Pennsylvania }\end{array}$ & $\begin{array}{l}\text { endowment fund, } \\
\text { programming, } \\
\text { build capacity, } \\
\text { technology and } \\
\text { marketing }\end{array}$ & $\$ 5,000,000$ \\
\hline $\begin{array}{l}\text { America's Black } \\
\text { Holocaust Museum }\end{array}$ & $\begin{array}{l}\text { Milwaukee, } \\
\text { Wisconsin }\end{array}$ & new building & $\$ 7,000,000$ \\
\hline $\begin{array}{l}\text { Hip Hop Hall of Fame } \\
\text { + Museum }\end{array}$ & $\begin{array}{l}\text { New York, } \\
\text { New York }\end{array}$ & new museum & $\$ 150,000,000$ \\
\hline $\begin{array}{l}\text { International African } \\
\text { American Museum }\end{array}$ & $\begin{array}{l}\text { Charleston, South } \\
\text { Carolina }\end{array}$ & new museum & $\$ 75,000,000$ \\
\hline $\begin{array}{l}\text { Harvey B. Gantt Center } \\
\text { for African-American } \\
\text { Arts + Culture }\end{array}$ & $\begin{array}{l}\text { Charlotte, North } \\
\text { Carolina }\end{array}$ & endowment fund & $\$ 10,000,000$ \\
\hline $\begin{array}{l}\text { Jackie Robinson } \\
\text { Museum }\end{array}$ & $\begin{array}{l}\text { New York, } \\
\text { New York }\end{array}$ & new museum & $\$ 42,000,000$ \\
\hline $\begin{array}{l}\text { Mississippi Civil Rights } \\
\text { Museumb }^{\mathrm{b}}\end{array}$ & $\begin{array}{l}\text { Jackson, } \\
\text { Mississippi }\end{array}$ & new museum & $\$ 17,000,000$ \\
\hline Motown Museum & Detroit, Michigan & new building & $\$ 50,000,000$ \\
\hline $\begin{array}{l}\text { National Museum of } \\
\text { African American } \\
\text { Music }\end{array}$ & $\begin{array}{l}\text { Nashville, } \\
\text { Tennessee }\end{array}$ & new museum & $\$ 25,000,000$ \\
\hline $\begin{array}{l}\text { National Museum of } \\
\text { African American } \\
\text { History and Culture }\end{array}$ & Washington, DC & new museum & $\$ 270,000,000$ \\
\hline $\begin{array}{l}\text { Studio Museum in } \\
\text { Harlem }\end{array}$ & $\begin{array}{l}\text { New York, } \\
\text { New York }\end{array}$ & new building & $\$ 175,000,000$ \\
\hline
\end{tabular}

Source: Author's documentary analysis. In some cases, fundraising goals changed over time.

Notes:

a This campaign through the National Trust for Historic Preservation focuses on preserving national historic sites including but not limited to museums.

b Includes private-sector campaign. Fundraising for this museum was combined with its partner museum, the Museum of Mississippi History. By December 2017, \$19,000,000 was donated by the private sector.

c Includes private-sector campaign. Ultimately, $\$ 320$ million was raised.

with me asking how and why patrons first got involved with supporting African American museums. This led to broader conversations about their views concerning the merits of and challenges surrounding African American museums, other philanthropic commitments, and personal backgroundsfor example, participation in other cultural activities, communities they grew up in, family involvement in nonprofits, and the like. At the end of interviews, participants also filled out a demographic questionnaire. 
As a whole, this is a group that is best described as upper-middle and upper class. The majority have graduate degrees and family incomes of at least $\$ 200,000$ or more. While their socioeconomic status generally places them in the upper-middle and upper class, they are a diverse group with respect to factors such as race and ethnicity, profession, generation, and lifestyle. Racially, most participants are black, but whites make up about 27 percent of the group. In addition, I talked with a small number of Caribbean Latinxs who also identify as members of the African diaspora. ${ }^{14}$ Professionally, most work in the private sector, but around one-third work for nonprofits or the government. In terms of generation, most participants were born before 1965 , but about one-third were born after and are members of Generation $\mathrm{X}$ or are Millennials. With respect to lifestyle, the group is about evenly split between cultural connoisseurs and cultural appreciators, with the latter being less involved with cultural activities, such as art collecting, more broadly.

Along with the formal in-depth interviews with supporters, on occasion I conducted formal interviews with museum staff. I also had many informal conversations with other supporters and staff over the course of my research. I also consulted several documentary sources, such as annual reports and published interviews with supporters. In addition, I visited archives that hold records for museums such as the NMAAHC and the Museum of the National Center of Afro-American Artists. My observations at African American museums, such as at fundraisers, and in the communities where they are located inform the analysis as well. In each city, I visited other cultural institutions and spent time in the surrounding neighborhoods. Because I try to visit African American museums whenever I travel, I also draw on observations and photographs from these visits. Finally, I created databases that include more than 2,000 donations of $\$ 25,000$ or more to African American museums and more than 500 black museum trustees.

In the tradition of ethnographic research, I use pseudonyms to keep confidential the identities of the people I interviewed and the museums that they support. ${ }^{15}$ Real names of supporters and institutions are used when information is garnered from publicly available sources. I also use the real names of institutions when I refer to my casual visits to exhibitions and the opening weekend of the NMAAHC. Because my visits to African American museums and analysis of archival and other documents cover a broader range of museums and supporters than the primary ethnographic research, it should not be assumed that any named individuals or museums are part of the ethnographic portion.

The in-depth interviews include supporters of seventeen museums in eleven cities, across each region of the United States. While most of the museums that these patrons support are among the larger African American museums in the country, they are a diverse group. They include museums with a range of focuses-history, art, history and culture, and so on-as well as sociodemographic contexts. ${ }^{16}$ Despite these differences, there 
was a consistent set of interests and concerns that emerged during the interviews. While dominant theories of museum patronage would assume that participants' takes on these issues would be shared by virtue of their common class position, I found that this was not entirely the case. In the next section, I discuss the scholarship on museum patronage and how the argument here advances it.

\section{Social boundaries and museum patronage}

There is a long tradition of sociological scholarship on museum patronage (Alexander 1996b; Balfe 1993; DiMaggio and Useem 1978a, 358-367; DiMaggio 1982a, 1982b; Zolberg 1974, 1981). For example, the influential cultural theorist Pierre Bourdieu argues that museums are mainly the province of members of the middle class not because they have a natural taste for fine art, but rather because social conditions-particularly, educational and family socialization-have habituated them to appreciate the art that is in these temples of culture (Bourdieu 1984; Bourdieu, Darbel, and Schnapper 1991). Similarly, Paul DiMaggio (1982a, 1982b) uses 19thcentury Boston Brahmin society as a lens to explicate cultural and class boundaries. He argues that through the establishment of the Museum of Fine Arts, Boston "cultural capitalists" not only formalized distinctions between high and popular culture but also strengthened their position as the ruling class. In other research on arts participation, DiMaggio and Michael Useem (1978c) also assert that institutional engagement with high culture, such as sitting on arts boards, nurtures social and ideological cohesion among members of the upper-middle and upper class. Similarly, Francie Ostrower's research $(1999,2002)$ highlights how museums are sites of class cohesion. She shows that by carving out a unique space within cultural organizations, specifically the space of philanthropy, upper-class relationships and identity are nurtured.

While various studies in this body of literature identify different mechanisms that link social boundaries and museum patronage, they generally share a focus on majority museums and a focus on class. ${ }^{17,18}$ More specifically, this scholarship emphasizes how middle- and upper-class engagement with museums is characterized by shared cultural values that emerge out of distinct class-based experiences. ${ }^{19}$ Given the disproportionate involvement of the upper-middle and upper class with cultural institutions, analyzing museum patronage through the lens of class is important. However, it is increasingly critical to also more thoroughly analyze how museum patronage is linked to other social divisions, such as race and ethnicity. While the upper-middle and upper class are overrepresented among museum patrons, there is increasing diversity within this group (Grams and Farrell 2008). Or, while museum patronage, such as trusteeship, is still a distinctively upper-middle- and upper-class practice, there is growing diversity among the upper-middle- and upper-class individuals who engage in it. For example, 
when major museums in the United States were founded in the mid-19th century, they were often governed by all-white boards. Although exclusively white cultural boards still exist, it is now more common for majority cultural organizations to have a small number of racial and ethnic minorities as trustees (Pogrebin 2017b; Bernstein 2016). ${ }^{20} \mathrm{~A}$ national report by the American Alliance of Museums and BoardSource finds that only 46 percent of museums boards are now all-white (BoardSource 2017, 9). ${ }^{21}$ Similarly, a recent study on diversity in New York City cultural organizations found that though whites make up the lion's share of board members, racial and ethnic minorities constitute around 20 percent of the city's cultural trustees (Schonfeld and Sweeney 2016, 27). The ranks of museum patrons are also becoming more diverse in other ways, such as age. For example, though most people on cultural boards are age 50 or older (Ostrower 2013), many museums are actively recruiting individuals in their $20 \mathrm{~s}, 30 \mathrm{~s}$, and $40 \mathrm{~s}$ to become members of special young professionals patron groups (Gelles 2014).

Not only has the diversity of museum patrons increased but also shifting demographics may accelerate this trend. With growth in the racial and ethnic minority middle and upper classes there is an increasing number of minorities who have the capital-economic, cultural, and otherwiseto participate in museum patronage. ${ }^{22}$ Understanding how a range of social identities intersect with cultural philanthropy is not only necessary because of shifting demographics, but also because of the growing mandate to diversify museum patronage. For example, in 2017 New York City released a cultural plan to encourage diversity, including board diversity, at the city's cultural institutions (Pogrebin 2017a). Some foundations also take board diversity into consideration when determining grants to cultural organizations and other nonprofits (Bertagnoli 2012). The pressure to diversify museum patrons also comes from within the field of museums itself (Facing Change, 2018). For example, the 2022 Smithsonian Strategic Plan includes a commitment to increasing board diversity (Goal 4, 2017). ${ }^{23}$ The growing concern with board diversity in the museum field is also evident by a national survey showing that 57 percent of museum directors believe that increasing board diversity is important (BoardSource 2017, 9). Similarly, when Johnnetta Cole (2015), then president of the Association of Art Museum Directors (AAMD), delivered a diversity-themed keynote address at the 2015 AAMD annual meeting, she made reference to the importance of philanthropic diversity noting that:

we cannot fully carry out the visions and the missions of our museums, and indeed our museums cannot continue to be of social value if we do not do what is required to have more diversity in ... the philanthropic and board leadership in our museums. ${ }^{24}$

While calls to diversify museum supporters generally focus on majority institutions, ethnic museums have also been addressed. At minority 
cultural institutions that typically have fewer resources than their majority counterparts, ${ }^{25}$ diversifying patronage is encouraged as a strategy to mobilize resources (DeVos Institute of Arts Management 2015, 16; Institute of Museum and Library Services 2004, 10). By having a more diverse philanthropic base, it is assumed, ethnic cultural institutions will have access to more money and other forms of capital. As Juanita Moore, CEO of the Charles H. Wright Museum of African American History asserts, racial wealth disparities mean that "African American museums cannot look solely to African American contributors" (Moore 2018, 87).

Globally, there are also stirrings to create a more diverse pool of museum patrons. For example, when the Zeitz Museum of Contemporary Art Africa opened in September 2017 in Cape Town, South Africa, critics voiced concern that its founder and major donor, Jochen Zeitz, is white and critiqued low black representation on the board (Sargent 2017; Suarez 2017). In the United Kingdom, the Arts Council England has supported efforts to increase diversity among museum board members across such lines as ethnicity and age ("Developing Sector Leaders" n.d.).

Demographic shifts, along with external and internal pressure, mean that it is critical to build theory and develop concepts that will allow us to better understand how a range of social boundaries intersect with museum patronage. However, as noted earlier, the sociological scholarship on museum patronage centers on one social boundary-class. We still know very little about how museum patronage varies within the upper-middle and upper class along lines such as race and ethnicity and generation. Diversity and Philanthropy at African American Museums departs from this conventional approach to studying museum patronage not only by analyzing African American museums, but also by analyzing in depth a range of social boundaries, including race and ethnicity, profession, lifestyle, and generation.

\section{Diversity and museum values}

I analyze diversity and philanthropy at black museums through the lens of what I term "museum values." I define "museum values" as the ways that patrons define what matters about the museums that they support. Museum values encompass broad understandings about why these museums should exist; specific perspectives about their strengths and weaknesses; and views about how they should be organized, governed, and adapted in the future. I explore how and why racial values vary among black and white patrons, professional values vary among patrons who work inside and outside of the business sector, cultural values vary among cultural connoisseurs and cultural appreciators, and contemporary values vary among older and younger supporters. I approach museum values as socially situated-or, as shaped by the environments and identities of supporters, as well as the cultural repertoires to which they have been exposed. ${ }^{26}$ Within this analytical 
framework, supporters' perceptions about what is peripheral or central to black museums can be understood as influenced by the beliefs and values of the various communities of which they are a part and their experiences and identities as members of those communities.

This explanatory approach engages the broader literatures on valuation and cultural reception. While Bourdieu's concept of the habitus, "a structuring structure which organizes practices and the perception of practices" (1984, 170), has been very influential in cultural sociology, more recent scholarship extends the concept beyond social class. In Bourdieu's formulation, class-related conditions of existence produce a set of universally coherent dispositions and competences. However, more recent research on cultural participation argues that class is only one of many social categories that structure taste and cultural engagement (Bennett et al. 2009; Banks 2010, 2017, 2018, forthcoming; Carter 2003; Dávila 2008, 2012; Gans 1999; Hall 1999). For example, in Culture, Class, Distinction, Bennett et al. (2009) preserve Bourdieu's concept of the habitus to explain cultural participation. However, they liberate the habitus from its sole focus on class to also account for categories such as ethnicity and age. Similarly, research on the cultural values of the upper-middle class also argues against Bourdieu's over-attentiveness to class. Critiquing Bourdieu's singular concern with class-related material conditions as a driver of values, as well as asserting that values are influenced not only by structure but also by culture itself, this research finds wide-ranging differences in how varying segments of the upper-middle class draw symbolic boundaries (Lamont 1992).

Research on cultural reception not only takes account of a range of social categories to understand cultural engagement, but it also puts a spotlight on how cultural objects acquire meaning at the time of reception (Griswold 1987; Hall 1980; Scott 2008). This approach asserts that, rather than being created solely at the time of production, the cultural meanings of objects, such as artworks and artifacts in museum exhibitions, emerge out of the process of consumption (Karp, Kreamer, and Lavine 1992). From this view, how audiences interpret or "decode" cultural objects is influenced by their lived experiences along with their preexisting beliefs and values. For example, in her research on natural history museums Monique Scott (2008) finds that visitors' interpretations of exhibitions vary across categories such as race and nationality and are influenced by their earlier experiences and ways of making sense of the world. Summarizing this approach, she writes, "Diverse individuals bring different understandings to museum exhibitions" (Scott 2008, 3).

Diversity and Philanthropy at African American Museums engages this scholarship by arguing that museum values are organized around a range of social categories and enabled by a combination of structural and cultural factors. Moreover, by centering patrons in the study of African American museums, the fluid meanings of these cultural institutions are revealed. 


\section{Overview of the book}

In the pages that follow I describe in depth how supporters of African American museums define what matters about these institutions. Each chapter presents a case study on how one domain of value-race, work, culture, and contemporaneity-is understood variously by different subgroups of supporters. While the analytic focus is on elaborating the distinct museum values of different segments of patrons, each chapter also considers the varying structural and cultural factors that can help to account for these differences.

Chapter 2 documents how patrons define the racial and ethnic value of black museums. I show how black and white patrons alike embrace a vision of African American museums as African American and allAmerican institutions. However, black patrons often slightly emphasize the former, and white patrons, the latter. I examine these differences in three contexts-philanthropic space, neighborhoods, and narrative. This chapter also examines how first- and second-generation African and West Indian supporters are often especially cognizant of African American museums as black diasporic spaces. Differences in how patrons define the racial and ethnic value of black museums are accounted for by factors such as individuals' varying racial and ethnic identities, social and organizational ties, access to racial ideologies, and experiences of racial and ethnic isolation. By illustrating how patrons from different racial groups place varying weight on the African American and all-American sides of black museums, Chapter 2 reveals the complexity of race at black museums.

Chapter 3 explores how patrons understand the value of African American museums in relationship to work. I describe how supporters who work in the for-profit sector, especially entrepreneurs, managers, and lawyers, have a heightened awareness of the professional value of African American museums. For them, giving to African American museums is appreciated not only for articulating values of corporate social responsibility that are espoused in firms and broader professional settings, but also as an avenue for enhancing professional relationships. On the one hand, giving reinforces understandings of the professional self as a moral community member, and on the other, it is recognized as an avenue for maintaining and enhancing professional outcomes. In contrast, supporters who work outside of business are less likely to see their patronage at black museums as part of a collective endeavor at their workplaces, or among their broader group of colleagues, to do good. It is also less common for them to see support of black museums as an opportunity to build relationships that will enhance their careers. The heightened emphasis on professional value among supporters in business is accounted for by factors such as the embeddedness of the business world in museum and other nonprofit philanthropy and the ideology of corporate social responsibility.

Chapter 4 explores the cultural side of African American museums. While research on cultural capital emphasizes how members of the middle and 
upper class share a deep enjoyment of high culture (Bourdieu 1984), a significant proportion of the supporters I interviewed are best described as appreciators rather than connoisseurs. While the latter are deeply engaged with culture in their broader lives, the former have a more distant relationship with culture. They enjoy culture and history, but it is not a defining feature of their lifestyles. I show how connoisseurs are distinguished from appreciators by paying particular attention to the cultural strengths and weaknesses of African American museums. Seeing themselves as cultural authorities, connoisseurs are comfortable making judgments about what African American museums must do to position themselves as leading cultural institutions. Their cultural eagle eyes are especially attentive to issues such as the legitimation of artists and the care of artworks and artifacts. I suggest that the social conditions associated with the lifestyles of connoisseurs enable their heightened focus on cultural value. With extensive exposure to culture, along with regular and intimate interaction with other cultural experts, connoisseurs have a high level of cultural competence that sensitizes them to the cultural dimensions of African American museums. Moreover, the conditions of their connoisseurship arm them with the knowledge and confidence to make authoritative cultural judgments about these institutions.

Chapter 5 turns the lens to contemporaneity. Like museums across the nation, staff at many African American museums are concerned with cultivating the next generation of supporters. To that end, museums such as the NMAAHC and the Museum of the African Diaspora (MoAD) have friends' groups for young professionals in their 20s, 30s, and 40s. In this chapter, I explore how these younger supporters place particularly strong emphasis on African American museums as contemporary spaces. While supporters across the generations are often attentive to positioning African American museums for success in the future, younger supporters are often most aware of, and open to, progressive shifts that will take them down this road. They are often especially adamant about the need for African American museums to be forums for dialogue about today's political issues, technologically savvy, and engaged with contemporary culture. Building on the sociological literature on generations, I discuss how these differences may be influenced by the distinct experiences and cultural exposures of older and younger generations, such as coming of age before or after the civil rights period and before or after the digital revolution and rise of hip-hop. This chapter brings to the fore not only how African American museums are engaged with recent political movements, such as Black Lives Matter, but also how they are aligned with contemporary culture, such as hip-hop music.

Although each substantive chapter centers on comparing patrons across one dimension of their identity-their race, generation, profession, or lifestyle-there are also differences within these categories. For instance, white and black connoisseurs assess the cultural value of black museums in varying ways, with the former often more concerned with issues such as 
black museums fostering a community of black collectors and hiring black staff. It is also the case that museum values vary across other social categories such as gender. For example, black women are often more focused on the role of black museums in the racial socialization of children. With the exception of ethnicity, which is analyzed in depth in Chapter 2, other identities and further within-group differences are occasionally noted but not extensively theoretically elaborated. ${ }^{27}$

Chapter 6 summarizes the book's empirical chapters, synthesizes the contributions for research on museum patronage and cultural patronage more broadly, and offers directions for future research. In particular, it elaborates how analyzing a range of social background characteristics provides a more complex understanding of the linkages between social and cultural boundaries. The conclusion also discusses findings in the context of practical concerns related to cultural patronage and diversity. While Diversity and Philanthropy at African American Museums focuses on patronage at black museums in the United States, the conclusion broadens the discussion to also address museums in other parts of the world, majority museums, and ethnic museums linked to other racial and ethnic minority groups. Since the conclusion highlights contributions related to cultural patronage, next I briefly outline the contributions to scholarship on African American museums.

\section{Rethinking African American museums}

In recent years there has been a small flowering of research on the establishment of black museums in the 1960s and 1970s (Burns 2008, 2013; Cahan 2016, 13-30; Wilson 2012). This scholarship makes visible how African American museums grew out of the broader movements for racial equality during this period. For example, it documents how founders' resolve to establish museums centered on black identity was in part a direct response to the absence of black history and culture in majority museums. From this angle of vision, African American museums appear as progressive counterpoints to majority museums. Diversity and Philanthropy at African American Museums contributes to the scholarship on African American museums not only by analyzing contemporary museums, ${ }^{28}$ but also by complicating the common understanding of the African American museum as the prototypical grassroots museum.

On the one hand, the values of patrons that are documented in this book do indeed reveal the progressiveness of today's African American museums. Among various subgroups of patrons there is heightened attentiveness to a host of issues that are progressive. This includes issues such as black membership on museum boards and museum engagement with contemporary political movements. Yet, other values of patrons reveal the establishment side of black museums. For example, just as some patrons at majority museums emphasize their value as institutions that anchor white upper-middle- and 
upper-class social life (Ostrower 2002), some patrons place value on black museums as contributing to social cohesion among the black middle and upper class. Similarly, just as patronage at majority cultural organizations is valued by some patrons as a career-enhancing activity (Useem 1984), it is also so valued by some supporters of black museums. In the same vein, just as some supporters at majority museums value them as vehicles to valorize culture that they personally deem worthy and have invested in (Zolberg 1974), so do some patrons at black museums. Finally, the hesitancy among some supporters to fully embrace the contemporary is in keeping with longstanding notions that the appropriate role for museums is to preserve the past (Altshuler 2005). These more conventional values of patrons reveal how rather than standing in pure opposition to majority institutions, African American museums are to a degree very "mainstream" themselves. In complicating the portrait of black museums as standing outside of the center, this book joins other recent scholarship on black museums. The sociologist Robin Autry (2017) argues that though black museums may appear to present alternative histories that are objective correctives of the past, the historical narratives that they put forward are in fact subjective and in some ways favor the status quo.

This book also advances the scholarship on black museums by shining a spotlight on how social boundaries other than race are negotiated within them. Focused on the emergence of black museums in the midst of the racial upheavals of the 1950s through 1970s, the existing literature highlights the racial politics that surround them (Burns 2008, 2013; Cahan 2016, 13-30; Wilson 2012). Diversity and Philanthropy at African American Museums adds to this scholarship by analyzing contemporary African American museums from a multifaceted perspective. While it elaborates the issues and challenges that black museums collectively face related to racial politics in the 21st century, it also reveals how they intersect with professional cultures, generational cultures, and varying styles of life. Given that cultural objects related to people of African descent-such as artworks produced by African Americans-are often understood through a purely racial lens (English 2010), it is critical that the extraracial meanings of African American museums are given more attention. As the next chapter demonstrates, race is fundamental to how African American museums should be understood. However, the subsequent chapters show the ways that other social boundaries are intertwined with these cultural institutions.

\section{Notes}

1 The efforts to establish a museum focused on African Americans on the National Mall date back to 1915 (Taft and Green Burnette 2003, 7-9).

2 I use the terms "African American museum" and "black museum" interchangeably to refer to museums and related cultural institutions in the United States with a significant focus on the history and/or culture of people from the 


\section{Diverse patrons, diverse values}

African diaspora. See Appendix 1 for a discussion of this category of museums. It should also be noted that while museums centered on culture and history from the African diaspora can be categorized according to this focus, they are also typically placed in other groupings depending on other relevant factors. For example, a museum such as the Museum of African American History in Boston can be categorized as both an African American museum and a history museum.

3 Sociological research on class and arts participation often distinguishes between the cultural engagement of the middle and working classes. At times, more finegrained distinctions are made such as distinguishing the upper-middle and upper class from all other classes or segments of the upper classes from one another (Bourdieu 1984; DiMaggio and Useem 1978b). Following other research on cultural patronage (DiMaggio and Useem 1978b, 359), I occasionally use the term elite to refer to members of the upper-middle and upper class.

4 Over the years, the names of these older black museums changed. The DuSable Museum of African American History, the Charles H. Wright Museum of African American History, and the African American Museum in Philadelphia were formerly known, respectively, as the Ebony Museum of History and Art, the International Afro-American Museum, and the Afro-American Historical and Cultural Museum. The Association of African American Museums (AAAM) was also founded under a different name-the African American Museums Association.

5 An important development in the field of black museums in the 1980s was the establishment of the National Afro-American Museum and Cultural Center in Wilberforce, Ohio in 1988. The museum didn't receive a federal allocation, but it was authorized by Congress earlier in 1981 (Ruffins 1998, 80).

6 This estimate is based on research that I conducted in 2016 to identify the population of black museums in the United States (see Appendix 1). As part of this research, I analyzed when the museums were founded. While on its face the founding date of a museum seems as if it is an objective fact, there are different understandings of what founding means. In museum histories, founding has a range of meanings, such as the date when a group first assembled to agree to open a museum, when an organization was granted 501(c)(3) status as a nonprofit, and when it opened to the public. Because of the variable definitions of founding, the dates that Figure 1.3 is based on refer to dates with a range of meanings. The general trend of more openings over time that is illustrated in Figure 1.3 broadly corresponds with other research on the development of the field (Association of African American Museums 2017, 18; Hayward and Werner 2008, 8; Hayward and Larouche 2018, 165).

7 Given that even the biggest African American museums today are relatively small compared to the largest "majority" museums (DeVos Institute of Arts Management 2015, 2), the classification of some black museums as "large" is a relative designation grounded in shifts in the historical evolution of the field.

8 Winfrey gave a million-dollar donation to the museum.

9 The need for sustainable philanthropy is also illustrated in the NMAAHC's 2017 budget request to Congress, which notes,

In 2017, strategic goals include planning and development strategies to include fund raising for support of Museum programs and research. Advancement staff will leverage visibility from the grand opening to 
motivate institutional and individual donors to fund the Museum's ongoing educational and public programs, exhibition development, and other activities.

(Smithsonian Institution 2016, 145)

10 Across the museum field there are examples of institutions of various types that have faced financial challenges partly related to costly building projects (Pogrebin 2011; Rich 2006; Whiting 2016).

11 This was noted in a grant application for the museum seeking \$1 million to help build capacity in "development, marketing/communications and earned revenue." It also notes that staff were "preparing to increase their income by approximately $\$ 1.5$ million over the current levels, from all sources, in the first year of the Museum's reopening" (New York Empowerment Zone 2016, 3).

12 A recent survey of black museums shows that staff describe funding as their biggest need (Association of African American Museums 2017, 7).

13 The interviews mainly occurred in three groups over the years from 2008 to 2016. Most took place in 2016. Other fieldwork and archival visits also took place during this period.

14 To provide perspective on the racial and ethnic composition of this sample, it is helpful to review the available evidence about who supports black museums more broadly. First, although there has been little systematic research comparing the racial and ethnic backgrounds of supporters of black and majority museums, available evidence suggests that there is a higher concentration of black supporters at the former (Banks 2017; Pogrebin 2004). Concerning trustees, though it is typical for large majority cultural organizations to have a white majority (Ostrower 2002,11), this does not appear to be a common pattern at black cultural organizations. For example, in a study of over 400 arts organizations across the United States, Francie Ostrower (2013) finds that while mainstream arts organizations tend to have majority white boards, most organizations with a majority black board focus on African American culture. Among a sample of trustees at fifteen large black museums analyzed for this study, only three have boards that are 60 percent or more white. In contrast, slightly over half have boards that are 60 percent or more black, and most of the remaining have boards with around a black-white split. Most supporters in this study give to black museums where the boards are 60 percent or more black. A smaller number of participants support museums where there is a roughly even split between black and white trustees. None give to museums with a majority white board. In the sample of trustees from large museums, there is not a high presence of Latinx, Asian, or Native American supporters. This is also the case among the black museums that interviewees in this study support. Concerning donations, there is also very limited systematic evidence comparing the race of donors to majority and black museums. As part of this study, I analyzed milliondollar gifts to the Smithsonian museum over the period 2005 to 2016. Gifts by blacks were overwhelmingly concentrated at the NMAAHC. I also analyzed gifts of $\$ 25,000$ or more at a sample of black museums. Here, I found that gifts by whites and blacks (rather than Latinx, Asians, and Native Americans) predominated, but it was more common for museums to have 60 percent or more of donations be from whites than to have 60 percent or more of donations be from blacks. 
15 In some cases, other identifying characteristics of individuals and institutions are altered to protect confidentiality. For example, names of cities and other geographic areas, as well as names of some artists and schools, are also often given pseudonyms when mentioned.

16 See Appendix 1 for an overview of how African American museums are defined and the types that exist in the broader population.

17 Across the literature there are varying definitions of what constitutes an "ethnic" versus a "mainstream" or "majority" cultural organization, and the preferred terminology used to refer to them (Matlon, Van Haastrecht, and Mengüç 2014, 36-38). I use the term "ethnic" museum to refer to cultural organizations that have an explicit focus on the history and culture of specific racial and ethnic groups, as well as institutions that have a significant focus on the history and culture of racial and ethnic minority groups. The former part of this definition captures any cultural organization that is explicitly named for a specific racial or ethnic group, such as the NMAAHC. The latter part of it speaks to organizations that do not include a specific racial or ethnic group in their name, yet the themes of concern significantly overlap with the history and culture of racial and ethnic minority groups. This includes organizations such as the National Civil Rights Museum and the proposed United States National Slavery Museum. Civil rights and slavery are not specifically African American subjects, yet they are themes that significantly overlap with the African American experience. In contrast, I use the terms "majority" and "mainstream" to refer to organizations that make claims of racial and ethnic universality, even if in reality the focus is on the history and culture of people of European descent. This includes organizations such as the National Museum of American History and the Museum of Modern Art in New York.

18 The focus on class and majority institutions is also common in research on other forms of patronage of such as music patronage (Accominotti, Khan, and Storer 2018).

19 Important exceptions to the focus on class are Ostrower's discussion of race and ethnicity in Chapter 3 of Trustees of Culture (2002), Ostrower's (2013) statistical analysis of racial and ethnic, age, gender, and occupational diversity on 476 cultural boards, and Diane Grams and Betty Farrell's Entering Cultural Communities: Diversity and Change in the Nonprofit Arts (2008), which investigates a range of forms of diversity.

20 The pattern of increasing board diversity is not unique to museums. In her research on the demographic profile of trustees at a range of nonprofits, including six museums, Rikki Abzug (1994, 116-117) finds that in 1931, just one organization in her sample had a nonwhite trustee. By 1961, boards were still 98.8 percent white. However, by 1991 , boards were only 86.7 percent white.

21 In her analysis of diversity on cultural boards, Francie Ostrower $(2013,8)$ finds that only 29 percent of the largest cultural organizations have all-white boards. While the percentage of all-white boards increases as the size of organizations becomes smaller, even a significant number of the smallest cultural organizationsaround 31 percent —are racially and ethnically diverse (Ostrower 2013, 8).

22 Although significant economic inequalities between racial and ethnic groups remain (Conley 1999; Oliver and Shapiro 1995; Shapiro 2005), there are improvements by some measures. In their research on the "power elite" in the United States, or those at the top of the class hierarchy, Richard Zweigenhaft 
and G. William Domhoff document how it has transformed to become more racially and ethnically diverse (Zweigenhaft and Domhoff 1982, 2003, 2011, 2018). For example, in 1955 the CEOs of all Fortune Magazine's leading 500 companies were white males; over time, this corporate elite added individuals from racial and ethnic minority groups to its ranks. In 2011, there were 15 Asian Americans CEOs and seven black CEOs, and in 2008 there were 13 Latinx CEOs (Zweigenhaft and Domhoff 2011). The boards of Fortune 500 firms have also diversified. For example, the first black became a board member of a Fortune 500 firm in 1964 (Zweigenhaft and Domhoff 2018, 88). By 2004, one estimate put the percentage of blacks on these boards at 8.1 (Zweigenhaft and Domhoff 2018, 95). Beyond the corporate sector, the class position of blacks improved dramatically between 1960 and 1980: for example, the number of blacks in white-collar jobs, a measure of middle-class status, increased by 124 percent (Collins 1997, 3). By 1970, one out of every four blacks could be considered middle-class, as opposed to one out of eight in 1960 (Landry 1987, $70)$. Although by some measures black class gains have slowed since this golden age, by 1995 almost half of all black workers could be considered middle-class (Pattillo-McCoy 1999, 3). Also, between 1970 and 2014 the proportion of blacks making six-figure salaries almost doubled, and the percentage of those making $\$ 75,000$ more than doubled. The percentage of blacks in these categories was 13 percent and 21 percent, respectively (Edsall 2017). Educationally, black college attainment has been in a long upward trend, with 23.3 percent of blacks 25 and over holding a college degree by 2017. In 1965 the figure was just 4.7 percent (US Census Bureau 2017).

23 Under Goal 4 in the Strategic Plan there is a commitment to "accelerating the diversification of our [the Smithsonian Institution's] constituents, boards, and workforces" ("Goal 4" 2017). A 2018 report is critical of Latinx trusteeship at the Smithsonian noting that "only 4 Latina/os have served on the Institution's Board of Regents; with no Latina/o representation on the Board since 2016" (Vera et al. 2018).

24 Also, in its online guide "Diversity, Equity, Accessibility, and Inclusion," the American Alliance of Museums (AAM) (n.d.) directs members to resources for building diverse boards. Similarly, in 2015, a blog post including a "primer" on "Art Museums, Diversity, and Leadership" was posted on the Association of Art Museum Directors (AAMD) website. Accompanying the post was a video conversation between Darren Walker, president of the Ford Foundation, which is a major funder of the arts, and Agnes Gund, president emerita of the Museum of Modern Art board. In their discussion they talked about the need to diversify museum boards ("Diversity in the Arts: Darren Walker and Agnes Gund" 2015).

25 Comparing the budgets of the largest African American and Latinx museums, theaters, and dance companies to the largest mainstream arts organizations in those categories, the DeVos Institute finds that those of the former are substantially smaller (DeVos Institute of Arts Management 2015, 2). A report from the National Center for Arts Research finds that after accounting for organizational age and sector, "culturally specific" and "mainstream" cultural organizations have budgets of similar size (Voss et al. 2016, 2).

26 In their research on ethnoracial stigma and discrimination, Michèle Lamont and her coauthors define cultural repertoires as "a set of tools available to individuals to make sense of the reality they experience" (Lamont et al. 2016, 21). 
27 While dimensions of value associated with each broad category-for example, race, work, culture, and the contemporary-are generally discussed in one dedicated chapter, given their overlapping nature they are also at times discussed in other chapters. For example, racial value is comprehensively discussed in Chapter 2. However, aspects of racial value are also implicitly and occasionally explicitly discussed in all other chapters. In general, black patrons tend to place greater weight on the significance of black museums for the black community across contexts such that there is more consideration among this group about black aspects of work, cultural, and contemporary value. Similarly, dimensions of value associated with culture are generally discussed in Chapter 4. However, in some cases they are also explored in other chapters. For example, racial narratives are explored in Chapter 2, and contemporary culture is analyzed in Chapter 5. While the distinct orientations of connoisseurs are systematically explored in Chapter 5, their greater emphasis on cultural value is typically evident across the board. Generally, black connoisseurs place more value on black narratives than do black appreciators, and younger generation connoisseurs are typically more concerned with certain aspects of contemporary culture-such as emerging visual artists-than are their younger appreciator counterparts.

28 Robin Autry's (2017) work is also among the new books looking at contemporary black museums.

\section{References}

Abzug, Rikki. 1994. "Variations in Trusteeship: A Six-City, Comparative Historical Study of the Evolution of Nonprofit Boards.” PhD diss., Yale University.

Accominotti, Fabien, Shamus R. Khan, and Adam Storer. 2018. "How Cultural Capital Emerged in Gilded Age America: Musical Purification and CrossClass Inclusion at the New York Philharmonic." American Journal of Sociology 123(6): 1743-1783.

African American Museums Association. 1988. Profile of Black Museums. American Association for State and Local History Book Series. Washington, DC: African American Museums Association.

Alexander, Victoria D. 1996b. Museums and Money: The Impact of Funding on Exhibitions, Scholarship, and Management. Bloomington: Indiana University Press.

Altshuler, Bruce, ed. 2005. Collecting the New: Museums and Contemporary Art. Princeton, NJ: Princeton University Press.

American Alliance of Museums. n.d. "Diversity, Equity, Accessibility, and Inclusion Resources.” Association of Art Museum Directors. Accessed June 21, 2018. www.aam-us.org/programs/resource-library/diversity-equity-accessibility-andinclusion-resources/.

Ardali, Azade. 1989. Black and Hispanic Art Museums. New York, NY: Ford Foundation.

Association of African American Museums. 2017. 2017 National Needs Assessment for the Association of African American Museums. Washington, DC: Association of African American Museums.

Austin, Joy Ford. 2003. National Survey of African American Museums: Prepared for the National Museum of African American History and Culture Plan for 
Action Presidential Commission. Washington, DC: National Museum of African American History and Culture Plan for Action Presidential Commission.

Autry, Robyn K. 2017. Desegregating the Past: The Public Life of Memory in the United States and South Africa. New York, NY: Columbia University Press.

Balfe, Judith H. 1993. Paying the Piper: Causes and Consequences of Art Patronage. Urbana: University of Illinois Press.

Banks, Patricia A. 2010. Represent: Art and Identity Among the Black Upper-Middle Class. New York, NY: Routledge.

- 2017. "Ethnicity, Class, and Trusteeship at African American and Mainstream Museums." Cultural Sociology 11(1): 97-112.

- 2018. "Money, Museums, and Memory: Cultural Patronage by Black Voluntary Associations." Ethnic and Racial Studies. https://doi.org/10.1080/ 01419870.2018.1540789.

—. Forthcoming. "High Culture, Black Culture: Strategic Assimilation and Cultural Steering in Museum Patronage.” Journal of Consumer Culture.

Bennett, Tony, Michael Savage, Elizabeth Bortolaia Silva, Alan Warde, Modesto Gayo-Cal, and David Wright. 2009. Culture, Class, Distinction. New York, NY: Routledge.

Bernstein, Jacob. 2016. “The Disrupters: Making New York's Cultural Boards More Diverse.” New York Times, July 30, 2016. Accessed August 10, 2016. www.nytimes.com/2016/07/31/style/diversity-cultural-boards-trustees-newyork.html.

Bertagnoli, Lisa. 2012. "Nonprofit Boards Slow to Diversify.” Crain's Chicago Business, November 3, 2012. Accessed January 10, 2017. www.chicagobusiness.com/article/20121103/ISSUE01/311039974/why-white-men-still-dominate-nonprofitboards.

BoardSource. 2017. Museum Board Leadership 2017: A National Report. Washington, DC: BoardSource.

Bourdieu, Pierre. 1984. Distinction: A Social Critique of the Judgement of Taste. Cambridge, MA: Harvard University Press.

Bourdieu, Pierre, Alain Darbel, and Dominique Schnapper. 1991. The Love of Art: European Art Museums and Their Public. Cambridge, UK: Polity Press.

Burns, Andrea A. 2008. "'Show Me My Soul': The Evolution of the Black Museum Movement in Postwar America." PhD diss., University of Minnesota.

- 2013. From Storefront to Monument: Tracing the Public History of the Black Museum Movement. Amherst: University of Massachusetts Press.

Cahan, Susan. 2016. "Electronic Refractions II at the Studio Museum in Harlem." In Mounting Frustration: The Art Museum in the Age of Black Power, 13-30. Durham, NC: Duke University Press.

Carter, Prudence L. 2003. 'Black' Cultural Capital, Status Positioning, and Schooling Conflicts for Low-Income African American Youth. Social Problems 50: 136-155.

Cole, Johnnetta Betsch. 2015. Keynote Address by Dr. Johnnetta Betsch Cole. 2015 American Alliance of Museums Annual Meeting, April 27, 2015. Accessed November 10, 2017. https://aamd.org/our-members/from-the-field/johnnettacole-museums-diversity-social-value.

Collins, Sharon M. 1997. Black Corporate Executives: The Making and Breaking of a Black Middle Class. Philadelphia, PA: Temple University Press. 
Conley, Dalton. 1999. Being Black, Living in the Red: Race, Wealth, and Social Policy in America. Berkeley: University of California Press.

Dávila, Arlene. 2008. "From Barrio to Mainstream: On the Politics of Latino/a Art Museums." In Latino Spin: Public Image and the Whitewashing of Race, 119137. New York, NY: NYU Press.

- 2012. Culture Works: Space, Value, and Mobility Across the Neoliberal Americas. New York, NY: NYU Press.

“Developing Sector Leaders.” n.d. Arts Council England. Accessed January 10, 2017. www.artscouncil.org.uk/funding/developing-sector-leaders.

DeVos Institute of Arts Management. 2015. Diversity in the Arts: The Past, Present, and Future of African American and Latino Museums, Dance Companies, and Theater Companies. Washington, DC: DeVos Institute of Arts Management.

Dickerson, Amina Jill. 1989. "The History and Institutional Development of African American Museums.” MA thesis, American University.

DiMaggio, Paul. 1982a. "Cultural Entrepreneurship in Nineteenth-Century Boston, Part 2: The Classification and Framing of American Art." Media, Culture, and Society 4: 303-322.

-1982b. "Cultural Entrepreneurship in Nineteenth-Century Boston: The Creation of an Organizational Base for High Culture." Media, Culture, and Society 4: 33-50.

DiMaggio, Paul, and Michael Useem. 1978a. "Cultural Democracy in a Period of Cultural Expansion: The Social Composition of Arts Audiences in the United States.” Social Problems 26(2): 179-197.

—. 1978b. "Cultural Property and Public Policy: Emerging Tensions in Government Support for the Arts.” Social Research 45(2): 356-389.

-1978c. "Social Class and Arts Consumption: The Origins and Consequences of Class Differences in Exposure to the Arts in America." Theory and Society 5(2): 141-161.

"Diversity in the Arts: Darren Walker and Agnes Gund." 2015. YouTube video, 4:53 min. Posted by ArtMuseumDirectors, September 21, 2015. www.youtube.com/ watch?v=bgcQZR7-Fsc.

Edsall, Margaret Horton. 2005. “Away We Go: African-American History Museum Opens Doors.” Capital, June 26, 2005. NewsBank.

Edsall, Thomas B. 2017. "Black People Are Not All 'Living in Hell." New York Times, April 27, 2017. Accessed May 10, 2018. www.nytimes.com/2017/04/27/ opinion/black-people-are-not-all-living-in-hell.html.

English, Darby. 2010. How to See a Work of Art in Total Darkness. Cambridge, MA: MIT Press.

Facing Change. 2018. Facing Change: Insights from the American Alliance of Museums' Diversity, Equity, Accessibility, and Inclusion Working Group. Washington, DC: American Alliance of Museums.

Feldman, Eugene Pieter. 1981. The Birth and the Building of the DuSable Museum. Chicago, IL: DuSable Museum Press.

Fleming, John E. 2018. "The Impact of Social Movements on the Development of African American Museums." The Public Historian 40(3): 44-73.

Gans, Herbert J. 1999. Popular Culture and High Culture: An Analysis and Evaluation of Taste. New York, NY: Basic Books.

Gelles, David. 2014. "Wooing a New Generation of Museum Patrons.” New York Times, March 19, 2014. Accessed April 10, 2017. www.nytimes.com/2014/03/20/ arts/artsspecial/wooing-a-new-generation-of-museum-patrons.html. 
Goal 4. 2017. "Goal 4: Understand and Impact 21st-Century Audiences." In Smithsonian 2022: Greater Reach, Greater Relevance, Profound Impact. Smithsonian Institution. Accessed June 10, 2018. www.si.edu/strategicplan/goal4.

Grams, Diane, and Betty Farrell. 2008. Entering Cultural Communities: Diversity and Change in the Nonprofit Arts. New Brunswick, NJ: Rutgers University Press.

Griswold, Wendy. 1987. "The Fabrication of Meaning: Literary Interpretation in the United States, Great Britain, and the West Indies.” American Journal of Sociology 92(5): 1077-1117.

Hall, John R. 1999. "The Capital(s) of Culture: A Nonholistic Approach to Status Situations, Class, Gender, and Ethnicity." In Cultivating Differences: Symbolic Boundaries and the Making of Inequality, edited by Michèle Lamont and Marcel Fournier, 257-285. Chicago, IL: University of Chicago Press.

Hall, Stuart. 1980. “Encoding/Decoding.” In Culture, Media, Language, edited by Stuart Hall, Dorothy Hobson, Andrew Lowe, and Paul Willis, 128-138. London, UK: Hutchinson.

Harris, Anita W. 2018. "Long Beach Considers New African-American Cultural Center.” Signal Tribune, May 31, 2018. Accessed June 10, 2018. https:// signaltribunenewspaper.com/37853/news/long-beach-considers-new-africanamerican-cultural-center/.

Hayward, Jeff, and Christine Larouche. 2018. "The Emergence of the Field of African American Museums." The Public Historian 40(3):163-172.

Hayward, Jeff, and Brian Werner. 2008. Assessment of the Field: African American Cultural Organizations. Northampton, MA: Association of African American Museums.

Institute of Museum and Library Services. 2004. African American History and Culture in Museums. Washington, DC: Institute of Museum and Library Services.

Karp, Ivan, Christine Mullen Kreamer, and Steven D. Lavine. 1992. Museums and Communities: The Politics of Public Culture. Washington, DC: Smithsonian Institution Press.

Lamont, Michèle. 1992. Money, Morals, and Manners: The Culture of the French and American Upper-Middle Class. Chicago, IL: University of Chicago Press.

Lamont, Michèle, Graziella Moraes Silva, Jessica S. Welburn, Joshua A. Guetzkow, Nissim Mizrachi, Hanna Herzog, and Elisa Reis. 2016. Getting Respect: Responding to Stigma and Discrimination in the United States, Brazil, and Israel. Princeton, NJ: Princeton University Press.

Landry, Bart. 1987. The New Black Middle Class. Berkeley: University of California Press.

Mack, Deborah L., and John S. Welch. 2018. “The State of Black Museums.” The Public Historian 40(3): 9-12.

Manly, Lorne. 2016. "Who Will Tell the Story of Slavery?” New York Times, June 19, 2016.

Matlon, Mina Para, Ingrid Van Haastrecht, and Kaitlyn Wittig Mengüç. 2014. Figuring the Plural: Needs and Supports of Canadian and US Ethnocultural Arts Organizations. Chicago, IL: School of the Art Institute of Chicago/Art Institute of Chicago.

McMorris, Frances. 2018. "Hillsborough Commissioners to Study Establishment of African-American Art Museum.” Tampa Bay Business Journal, May 14, 2018. Accessed June 10, 2018. www.bizjournals.com/tampabay/news/2018/05/14/ hillsborough-commissioners-to-study-establishment.html. 
Montagne, Renee. 2004. "Profile: Difficulties African-American Museums Are Facing to Raise Funds and Attract a Broader Audience." Morning Edition. National Public Radio, June 23, 2004.

Moore, Juanita. 2018. "Transitions in Time: Leadership and Governance in African American Museums." The Public Historian 40(3): 74-89.

New York Empowerment Zone. 2016. "New York Empowerment Zone Corporation Meeting of the Directors: Wednesday, September 21, 2016.” Board Materials, New York Empowerment Zone Corporation, New York, NY. Accessed November 10，2017. https://esd.ny.gov/sites/default/files/news-articles/09212016_NYEZ_ BoardMaterials.pdf.

Oliver, Melvin L., and Thomas M. Shapiro. 1995. Black Wealth/White Wealth: A New Perspective on Racial Inequality. New York, NY: Routledge.

Ostrower, Francie. 1999. "The Arts as Cultural Capital Among Elites: Bourdieu's Theory Revisited.” Poetics 26: 43-53.

- 2002. Trustees of Culture: Power, Wealth, and Status on Elite Arts Boards. Chicago, IL: University of Chicago Press.

—_. 2013. "Diversity on Cultural Boards: Implications for Organizational Value and Impact." Working Paper, National Endowment for the Arts, Washington, DC.

O’Toole, Christine H. 2015. “The August Wilson's 2nd Act.” Forum: The Pittsburgh Foundation Quarterly Fall 2015: 12-14.

Pattillo-McCoy, Mary. 1999. "Middle Class, Yet Black: A Review Essay." African American Research Perspectives 5: 25-38.

Pogrebin, Robin. 2004. "Many Arts Groups in City Lag in Naming Blacks as Trustees.” New York Times, May 2, 2004. Accessed August 25, 2016. www.nytimes.com/ 2004/05/25/nyregion/many-arts-groups-in-city-lag-in-naming-blacks-as-trustees. html.

. 2011. "Options Dim for Museum of Folk Art." New York Times, August 24, 2011. Accessed August 25, 2016. www.nytimes.com/2011/08/25/arts/design/ american-folk-art-museum-weighs-survival-strategies.html.

—. 2017a. "De Blasio, with 'Cultural Plan,' Proposes Linking Money to Diversity." New York Times, July 19, 2017. Accessed August 10, 2017. www. nytimes.com/2017/07/19/arts/design/new-york-cultural-plan-museums.html.

— 2017b. "It's a Diverse City, but Most Big Museum Boards Are Strikingly White.” New York Times, August 22, 2017. Accessed August 25, 2017. https:// nyti.ms/2vlbVw8.

Post Staff Report. 2007. "Freedom Center Names New CEO.” Cincinnati Post, February 24, 2007. ProQuest.

Prabhu,Maya T.2018. “Savannah Democrat Wants Georgia to Have an African-American Museum.” Atlanta Journal-Constitution, January 31, 2018. Accessed February 10, 2018. www.myajc.com/news/state-regional-govt-politics/savannah-democratwants-georgia-have-african-american-museum/VwZ5iYZy0VtyJCv2m90jhL/.

Rich, Motoko. 2006. "Build Your Dream, Hold Your Breath." New York Times, August 6, 2006. Accessed January 10, 2015. www.nytimes.com/2006/08/06/arts/ design/build-your-dream-hold-your-breath.html?mtrref=undefined.

Ruffins, Fath Davis. 1992. "Mythos, Memory, and History: African American Preservation Efforts, 1820-1990.” In Museums and Communities: The Politics of Public Culture, edited by Ivan Karp, Christine Mullen Kreamer, and Steven D. Lavine, 506-611. Washington, DC: Smithsonian Institution Press. 
1998. "Culture Wars Won and Lost, Part II: The National African-American Museum Project.” Radical History Review 70: 78-101.

Sargent, Antwaun. 2017. "Africa Gets Its First Major Contemporary Art MuseumBut Challenges Lie Ahead." Artsy, September 17, 2017. Accessed September 25, 2017. www.artsy.net/article/artsy-editorial-africa-first-major-contemporaryart-museum-challenges-lie-ahead.

Schonfeld, Roger C., and Liam Sweeney. 2016. Diversity in the New York City Department of Cultural Affairs Community. New York, NY: Ithaka S+R.

Scott, Monique. 2008. Rethinking Evolution in the Museum: Envisioning African Origins. London, UK: Routledge.

Shapiro, Thomas M. 2005. The Hidden Cost of Being African American: How Wealth Perpetuates Inequality. New York, NY: Oxford University Press.

Smithsonian Institution. 2016. Fiscal Year 2017 Budget Justification to Congress, Submitted to the Committee on Appropriations, Congress of the United States. Washington, DC: Smithsonian Institution.

Suarez, Cyndi. 2017. "The First Contemporary Art Museum in Africa Is Run by White Men.” Nonprofit Quarterly, September 21, 2017. Accessed August 10, 2017. https://nonprofitquarterly.org/2017/09/21/first-contemporary-art-museumafrica-run-white-men/.

Taft, J. Richard, and Alice Green Burnette. 2003. Final Report: Planning and Organization for a Private Sector Fundraising Campaign in Behalf of the National Museum of African American History and Culture. Smithsonian Institution Archives, Accession 07-172. Washington, DC: National Museum of African American History and Culture, Planning Records.

Trescott, Jacqueline, and J. Freedom du Lac. 2012. "African American Museum's Fundraising Models: King Memorial and Obama Campaign.” Washington Post, February 17, 2012. Accessed January 10, 2017. www.washingtonpost.com/ entertainment/museums/african-american-museums-fundraising-models-kingmemorial-and-obama-campaign/2012/02/09/gIQA5QW9JR_story.html?utm_ term $=.7 \mathrm{~b} 7 \mathrm{da} 774 \mathrm{a} 123$.

US Census Bureau. 2017. Table A-2. Percent of People 25 Years and Over Who Have Completed High School or College, by Race, Hispanic Origin, and Sex: Selected Years 1940 to 2016. Retrieved from www.census.gov/data/tables/2016/demo/ education-attainment/cps-detailed-tables.html.

Useem, Michael. 1984. “Corporate Philanthropy." In The Inner Circle: Large Corporations and the Rise of Business Political Activity in the U.S. and U.K., by Michael Useem, 118-125. New York, NY: Oxford University Press.

Vera, Daisy, Chon A. Noriega, Sonja Diaz, and Matt Barreto. 2018. Invisible No More: An Evaluation of the Smithsonian Institution and Latino Representation. Los Angeles: UCLA Chicano Studies Research Center. https:/ucla.app.box.com/ s/2as38f40oa8e4k5aep7jjxdas71lc6vl.

Voss, Zannie Giraud, Glenn Voss, Andrea Louie, Zenetta Drew, and Marla Rubio Teyolia. 2016. Does "Strong and Effective" Look Different for Culturally Specific Arts Organizations? Dallas, TX: National Center for Arts Research.

Whiting, Sam. 2016. “Asian Art Museum Rising to Put Tough Days Behind.” San Francisco Chronicle, April 16, 2016. www.sfchronicle.com/art/article/Asian-ArtMuseum-rising-to-put-tough-days-behind-7253168.php.

Wilson, Mabel O. 2012. Negro Building: Black Americans in the World of Fairs and Museums. Berkeley: University of California Press. 
32 Diverse patrons, diverse values

Zolberg, Vera L. 1974. "The Art Institute of Chicago: The Sociology of a Cultural Organization.” PhD diss., University of Chicago.

- 1981. "Conflicting Visions in Art Museums." Theory and Society 10(1): 103-125.

Zweigenhaft, Richard L., and G. William Domhoff. 1982. Jews in the Protestant Establishment. New York, NY: Praeger.

- 2003. Blacks in the White Elite: Will the Progress Continue? Lanham, MD: Rowman and Littlefield.

- 2011. The New CEOs: Women, African American, Latino and Asian American Leaders of Fortune 500 Companies. Lanham, MD: Rowman and Littlefield.

2018. Diversity in the Power Elite: Ironies and Unfulfilled Promises. Lanham, MD: Rowman and Littlefield. 


\section{African American/All-American}

The commission shall develop a fundraising plan for supporting the creation and maintenance of the Museum through contributions by the American people, and a separate plan on fundraising by the African American community.

(H.R. 3442 2001)

In 2003, after President George W. Bush signed into law the legislation that established the National Museum of African American History and Culture (NMAAHC), J. Richard Taft, president of the Taft Organization, and Alice Green Burnette, principal of Advancement Solutions, presented a report to Congress. The advancement consultants had been charged with developing a plan to raise more than $\$ 200$ million in private funds to help build the museum. Although they rejected the legislation's call to create wholly separate fundraising plans for different racial groups, ${ }^{1}$ they recommended that the campaign take heed of their findings concerning racial differences in response to the NMAAHC. In their report, which was based on over a year of study including focus groups and interviews with targeted donors, the consultants were cautiously optimistic about generating interracial support for the museum. Although prospective white donors were less excited about the NMAAHC than their black counterparts, Taft and Green Burnette advised that the former could be successfully cultivated by emphasizing the museum's interracial dimensions:

Our findings indicate that the case for support-as currently constituted-evokes a powerful response from African Americans and can be expected to motivate significant contributions at all levels in that community. Although enthusiasm from the non-African American community appears to be more restrained, this study suggests that it may be possible to build significant support among white Americans if the NMAAHC Museum campaign is depicted as "all American," featuring both African American and white American leadership and involvement.

(Taft and Green Burnette 2003, 6) 


\section{African American/All-American}

This chapter further examines how black and white patrons respond to African American museums. More specifically, I elaborate how members of both groups define the racial and ethnic value of these cultural institutions. I find that patrons often see black museums as having dual identities-one black and the other American. Indeed, it is not uncommon for patrons of all races to use phrases along the lines of "African American history is American history" or "African American culture is American culture" to describe why African American museums should be broadly supported. However, while blacks and whites alike generally embrace a vision of black museums as both "African American" and "all-American," black supporters often have a heightened awareness of their relevance for the black community, and white supporters often have a particular sensitivity to their significance for whites. ${ }^{2}$ This chapter centers on the African American/all-American duality, but the last section also introduces a further distinction: the African American museum as African American versus African diasporic. I document how first- and secondgeneration supporters of African descent often place particular emphasis on the latter. ${ }^{3}$ To understand these racial and ethnic variances, I draw upon the broader literature on the black and white middle and upper classes.

Since the 1960s, the class structure in the United States has transformed to include more middle- and upper-class blacks (Edsall 2017; Harvey Wingfield 2011; Landry and Marsh 2011; Watkins 2005, 260-267; Wilson 1980; Wingfield 2013; Zweigenhaft and Domhoff 2011). Although there is ongoing debate about the salience of race versus class in shaping opportunities (Willie 1979; Wilson 1980), research consistently shows that the life chances, understandings of self, and beliefs about the opportunity structure of middleand upper-class blacks and whites often diverge (Collins 1997; Dawson 1994; Hochschild 1995; Pattillo-McCoy 1999). For example, while legal barriers restricting opportunities for blacks have eroded, racial bias continues (Bobo, Kluegel, and Smith 1997; Bonilla-Silva 2010; Feagin and Sikes 1994). Similarly, black identity often remains a salient category of belonging for middle- and upper-class blacks (Lacy 2004, 2007; Tatum 1987; Willie 2003).

Sociologists have long argued that racially distinct structural and symbolic realities contribute to different patterns of cultural engagement among middleand upper-class blacks and whites. For example, in the 1950s E. Franklin Frazier (1997[1957]) asserted that the "black bourgeoisie" managed racially rooted status anxieties through imitating the lifestyle of elite whites. Although his work has been highly critiqued, one fundamental assumption underlying his research, that racial boundaries influence cultural engagement, is widely accepted. Like Frazier, contemporary researchers also explicate how middleclass blacks negotiate racial inequality through engagement with mainstream high-status cultural symbols (Lacy 2007, 72-113; Molnár and Lamont 2002, 88-111). However, there is also increasing analysis of their engagement with black culture (Banks 2010, 2017, 2018, forthcoming; Fleming and Roses 2007). In comparison to their white counterparts, middle-class blacks have higher levels of engagement with some forms of black culture (DiMaggio 
and Ostrower 1990; Halle 1993, 158-159). ${ }^{4}$ A desire to nurture their racial identity motivates some middle-class blacks to seek out black culture such as art by black visual artists (Banks 2010, 2019; Crockett 2017; Grams 2010). Although Francie Ostrower's Trustees of Culture (2002) theoretically centers class in interpreting cultural patronage, a section in one chapter also explores how race and ethnicity may influence the experience of minorities on museum and opera house boards. For example, a black trustee whom she interviews believes that he "sets the tone" for his organization's outreach to minority communities (Ostrower 2002, 50). This chapter builds on this literature by describing how race and ethnicity organize supporters' conceptions about the value of African American museums.

Although all supporters typically embrace African American museums as having worth for blacks and nonblacks, black supporters are particularly cognizant of the former, and white patrons are especially aware of the latter. I develop this argument by examining three dimensions of racial value: philanthropic space, neighborhoods, and narratives. Consistent with research demonstrating that black spaces and places (Lacy 2004), or organizations and neighborhoods, play an important role in black middle-class social and civic life, I find that black supporters are often especially aware of the function that African American museums play in the broader fabric of the black community. In line with research demonstrating that middle-class blacks seek out black culture to nurture black identities (Banks 2010, Banks 2018, forthcoming), I show how black patrons are often especially conscious of the worth of black-centered narratives in African American museums and their transformative power for black museum-goers. In comparison, I find that white supporters often place particular emphasis on the value of black museums as interracial spaces and places. It is also not uncommon for them to be especially sensitive to the value of black museums for articulating interracial narratives that can change the hearts and minds of whites. I posit that this interracial emphasis is enabled by both structure and culture. For example, structurally, white patrons are often entering black contexts, such as black neighborhoods and events, where blacks are in the majority. Through their very presence in these spaces—or by going over to the "other side"some whites see themselves as interracial bridges who link racial communities. I also propose that factors such as whites' racial and ethnic identities contribute to their heightened focus on black museums as spaces to highlight interracial narratives. In essence, varying past and present experiential realities and differential access to broader values, beliefs, and meanings related to race and ethnicity may contribute to black and white patrons having different degrees of clarity about the different racial sides of black museums. ${ }^{5}$

\section{Spaces}

Although it has long been understood that the space of cultural philanthropy is inhabited by the upper-middle and upper class, what is less 
recognized is that this space is also further divided along racial and ethnic lines. Across each city that I visited, the leading majority cultural institutions are supported mainly by whites, while black museums are disproportionately supported by blacks. This pattern, whereby white and black elites are segregated into different social worlds, is long-standing. Sociologists studying the black middle class across various time periods document a pattern of segregated organizational life that distinguishes members of the black middle class from their white counterparts (Frazier 1997[1957]; Graham 1999; Lacy 2004, 908-930; Landry 1987). There are parallel organizational spheres with specifically black and white middleclass organizations such as sororities and fraternities. ${ }^{6}$ One black trustee who describes his city as "fairly segregated" distinguishes the separate communities by race referring to them as "black Centersville" and "white Centersville." Although the range of separation varies from city to city and there is typically a degree of overlap, racial segregation is an ongoing reality in middle- and upper-class organizational life.

The separation in social and civic life maps onto the cultural world. For example, while black middle-class organizations, such as Sigma Pi Phi Fraternity (or the Boulé) and The Links, Inc., were million-dollar donors to the NMAAHC, no white social organizations were among large donors to the new museum (Banks forthcoming). ${ }^{7,8}$ Philanthropy at black museums is experienced by some black supporters as an extension of this broader black organizational life. In the past, formal racial barriers forced middle-class blacks to craft separate social, civic, and educational spaces, and today some middle-class blacks self-consciously seek out these spaces. Informal racial barriers continue, and black spaces can provide respite from them (Allen 1992; Lacy 2004; Pattillo 2007). Moreover, though blacks are a minority in the United States, upper-middle- and upper-class blacks are an even smaller minority. Black organizational spaces are an escape from being "the only one in the room," as one black trustee explains. When a Millennial supporter moved to her predominately white city, she became a patron to connect with other blacks there.

So, I moved to [Azure City] about four years ago, and one of the things I noticed when I first moved ... was [that there was] not a ... strong sense of black community here. Having gone to [an Historically Black College and University (HBCU)] I was not cool with that ... I couldn't grow and thrive and do what I wanted to do professionally and socially without a strong sense of community. So, that's basically what brought me to the museum.

Jennifer, a black supporter in another city, also casts light on the social dimensions of patronage when she describes how she first became involved with her local African American museum. "The types of events that they were sponsoring sparked my interest," she says. 
They had the Friday Jazz event. I would go and see African American art and meet other people who were interested in it. A good friend of mine [who is black] — she was my former boss and we became good friendsis very involved in the museum. Supporting some of the activities that she was participating in was sort of my introduction to the group. You have a friend, you try to support the friend, and before you know it, you say, "Hmmm, I might like this."

Social ties are at the heart of Jennifer's patronage. She recently commissioned a work by an African American artist for the museum. It was to honor the friend and colleague who introduced her to the organization. "My dear friend did something very nice for me, and one way for me to thank her was to try and find something that she likes and support that," Jennifer says. When I ask Jennifer whether she knows other patrons at the museum socially she shares that it is "probably 50-50."

I knew a couple of people from church and from other organizations that I've worked with or now work with. I knew a couple of neighbors as well. A lot of African Americans in the city belong to the same organizations. There are not a lot of organizations and so they belong to the same organizations. Every black person I know does something for, is a member of, is on the board, sponsors events at, or is a friend of the museum. It gets a lot of support. It has great community support.

Jennifer notes how she connects with blacks who are part of her broader network through involvement with the museum. This is in stark contrast to other philanthropic events in the city, where she is often the only black, or one of a few. "It's nice being around African Americans whom you have things in common with," Jennifer says, explaining why the museum's fundraisers are so appealing to her.

The first time that I went to the winter gala was last year, and there wasn't one thing there that I didn't like. Folks who are supporters donate art, and people bid on it. These are people I know in the community and who I like. For some reason, there was not one thing there that I wouldn't want. The whole point is to make a lot of money and run up the bids. Then for the [summer] gala, I just like parties. They have nice food, nice music. The night is great. I go to a lot of black tie events that are white-centric, and this is the one thing where you go and it's mostly black people, and it's beautiful, beautiful black people. It's like all of the pretty people are there. So, my husband and I, we like that. We've only been twice. I invited my sister, and she and her husband will come and join us. All the events are so classy. They're well done and well put together. The people that associate themselves with the museum are just very refined, decent, nice people that you want to be around. 
Echoing Jennifer's sentiment, a trustee at a black museum located on the other side of the country comments that the yearly gala offers "another place for African Americans to gather." "You see a lot of your friends and you're able to talk art over wine and feel pride," she reflects. When I attend a gala for one museum it is clear that it is a hub for bringing together the black middle and upper class in the city. The gala is held on a warm summer evening. A few hundred supporters are at the event. The women sport freshly coiffed hair, tasteful makeup, and elegant evening gowns, while the men wear formal suits and tuxedos. In a rotunda with modern and contemporary art, hors d'oeuvres are served and jazz plays in the background. An older crowd gathers here. In a courtyard, a DJ spins popular hip-hop hits as the younger crowd dances. The atmosphere is festive, and people interact with familiarity and ease. Throughout the evening, patrons greet friends and acquaintances with hugs and kisses. Well-known black middle-class social organizations and black civic organizations also have a formal presence as institutional supporters of the event. While there are some whites, and an even smaller number of Latinxs and Asian Americans present, for the most part it is a black crowd.

Museum staff also comment on how fundraisers are important for developing social ties-particularly social ties among blacks. When I ask one staff member if networking is common at her museum's major fundraiser she says,

Are you kidding? It [the Goldsville African American Museum gala] is the networking situation of the year. I think people do it just for the social connections. ... Not only do you see fabulous clothes, it's a good party. Is it like network central? Absolutely.

In contrast to attendees at other museum fundraisers in the city, the crowd at her museum's gala is primarily black. But, some prominent whites also attend. "Attending gives you prestige in the white community too," she explains. She recalls a gala a few years ago where she ran into one of her white neighbors. "I went there, and I met a woman who lived in my building. She said, 'I heard this was the place to come." While this staff member believes that the fundraiser helps to establish one's reputation within the city's upper-middle and upper class at large, she sees it as especially important for doing so among the community's black elite. "There's still a lot of segregation among communities in this country. So, I think you especially get prestige within the African American community," she says. A staff member at a different museum also comments on the role of black museum patronage in nurturing bonds and gaining recognition among the black middle and upper class in particular. "I think it plays this role within all communities," she acknowledges. "But, within the black community, definitely. It adds to things you can talk about... It has a lot to do with that. Being seen in the right places also helps.” 
At museum events, many of the middle- and upper-class blacks know one other and value their patronage for reinforcing these existing bonds. In contrast, Steven, who has served on the boards of the leading majority and black museums in his city, describes how the majority museum draws a different crowd. He is one of a few blacks in the community who have served on the board of the respected Blue City Art Museum. Historically, the board has been mainly composed of individuals from long-standing elite white families in the city. I ask him to compare patronage at the two museums. "There are some events at the Blue City Art Museum that I probably don't even know about," he says. "Why wouldn't you know about them?" I ask.

STEVEN: They're at private homes. Also, I'm not in some of their clubs. There are people who are very comfortable with me being on the board of the museum, but I've never been to their house.

PATRICIA: Why do you think that is the case?

STEVEN: Hello? I think racism is alive and well in America and in every class. PATRICIA: When you say every class, what do you mean?

STEVEN: From high to low, it is alive and well.

PATRICIA: Even among the people on the board?

STEVEN: There are certain things that are okay to do, but a lot of things

I don't know anything about. Like when you get into, well, thirdgeneration history. There are still a lot of old connections here. I just can't tune into it. There are also vacationing patterns and private clubs. There is the Fox Club. It is very Princeton-heavy. So to get in, to be non-Princeton, nonwhite, that's heavy. I was an exception period, and I know it. Period. But I am a former trustee of the museum, so if you're ever going to make an exception, well then ... [voice trails off].

In Digby Baltzell's (1964) research on the Philadelphia elite, he describes the intimate social ties among the old white Protestant families in the city. Their shared sense of honor and familiarity was bred through living in the same neighborhoods, joining the same social organizations, and attending the same prep schools and elite colleges. Writing in the 1950s, Baltzell notes how nonwhite and non-Protestant elites are excluded from this circle. Decades later, Steven sees similar bonds among his city's old-money elite. His membership on the board of the city's oldest art museum and in other organizations gives him some foothold in this world. Yet, if long-standing family ties are necessary for complete acceptance, it will never be a group where he is fully at home. In contrast, he is at the nucleus of the black elite that comes together at the African American museum.

For black patrons, African American museum events like galas are often a welcome aspect of their patronage. The opportunity to connect with middle- and upper-class blacks who are already in their social circles, as well as make new connections, is cherished. This is cast in relief when I look through society page photos of fundraising events at the major 
African American and majority museums in different cities. Inevitably, the black events have a concentration of blacks, while events for the majority museums picture few, or in some cases, none at all. Patrons like Steven who support majority and black museums in their cities directly experience this difference. It is within this context of having few opportunities to interact with blacks in the cultural world, as well as in other aspects of their lives, that they place value on connecting with other blacks at African American museums.

In his oft-cited essay “The Talented Tenth,” W.E.B. DuBois 1996 [1903] asserts, "The Negro race, like all races, is going to be saved by its exceptional men." While he later amended his thesis (Waite 2001), his beliefs concerning racial uplift and class had long taken hold among the black middle and upper class. This value, that middle- and upper-class blacks have a duty to help advance the race, is evident within the context of museum philanthropy. This belief, that the sphere of black cultural organizations is where middle- and upper-class blacks have a particular obligation for leadership, is fueled not only by broader racial uplift ideology but also by the perception that leadership at majority cultural institutions is in a sense "owned" by middle- and upper-class whites.

When I interview Lucy, the attachment that black patrons have to her city's African American museum is brought into relief when she talks about the tight connection that the white upper-middle and upper class have with the city's largest art museum. Like Steven, Lucy is a black patron who has served on the boards of the majority and black museums in her community. I ask her to describe differences between the two boards. She feels that white board members feel a sense of ownership of the majority museum. In her mind, they believe, "We're at the table, because we're supposed to be at the table. It's our turn to be at the table." Given the large contingent of board members who are 50 years and older I ask her if this attitude is primarily related to age. "Not entirely. It's a function of birthright," Lucy replies. "As African Americans, we have witnessed this all our lives."

Take a white person who is a vice president at his company. He feels that "of course, I'm supposed to be here. I'm used to being here. I don't know that you are supposed to be here. But, I'm supposed to be here. The art on the walls and the sculptures all represent who I am-European American. This museum represents who I am. Does it represent you? Should it represent you?" So, it's not age. It really isn't age in my opinion.

Lucy views white elites as feeling a racial and class connection to the majority art museum. From her perspective, they see it as "their museum." In contrast, for some black patrons, African American museums are valued as the institutions in the cultural world to which they are distinctly connected. These are organizations that black Americans have the opportunity to lead and that focus on culture from their racial group. A staff member describes this perspective, noting that 
for black patrons supporting her museum is important because there's "a sense of pride and support for something that belongs to them."

However, for black board members who take a leadership role in cultivating major gifts, it can sometimes be challenging to reconcile broader community expectations that blacks will play a central role in the philanthropic leadership of black museums with the harsh reality that wealth is still concentrated among whites (Conley 1999; Oliver and Shapiro 1997; Shapiro 2005). One former board chair who helped to secure a seven-figure donation from a white foundation in his city is sensitive to criticism from some segments of the black community that there isn't enough black "control" of the museum. He notes that though there have been commitments made by some black middle-class organizations in the city, as well as black families, the unequal racial distribution of wealth makes it challenging to realize the ideal of having black cultural uplift funded primarily by donations from blacks. "The biggest thing right now is trying to get a consistent funding base. I think that's our biggest challenge and I think most African American museums across the nation [have it too]," he explains.

I think we do have African Americans who give, but nothing in the sense of major multi-million dollar gifts and the like. At least I haven't seen too many... If you look at most of the signature African American museums [and cultural organizations], they're not driven by an AfroAmerican governing body that is the primary sponsor. At Alvin Ailey [a black dance company] it's the Weills [a wealthy white family]. ${ }^{10}$... When you really look at the top tier donors who are there, they're not AfricanAmericans per se, although you're starting to see some. We went to Alvin Ailey in December, and we saw some of the actors and stars who are our patrons. But big endowment funds, that big endowment fund that's totally managed and run by African Americans, I don't know too many. Now, that just might be my lack of knowledge, but that's what I think is missing. So, what we wind up doing ... is we have fundraisers. And, we solicit a lot. But, we are not necessarily getting what I call the big gifts, and consistent big gifts over time. Even the one that's going up in DC [the NMAAHC] has got its problems. If there isn't a big driver, it's going to ... need white America to help fund it. So, the big challenge is how do you get a community to consistently own it and make it a priority of their giving... If you can't get an endowment, or you don't have a large enough pool, you're spending too much of your time trying to raise what I call "small dollars," and that's our big challenge—can we get out from under having to do that so we can then direct dollars to programming.

I interviewed this trustee before fundraising for the NMAAHC was complete and all of the major gifts were reported. While the racial pattern of funding for this museum complicates his statements, it does not entirely contradict them. Analyzing million-dollar gifts to all of the Smithsonian 
museums for the years 2005 to 2016, I found that black donors were far more likely than white donors to give to the NMAAHC. Looking at funding for the NMAAHC among the wealthiest Americans offers further insight on racial patterns of support for the museum. In 2016 just two African AmericansOprah Winfrey and Robert Smith-were among the 400 wealthiest people in the United States. Both were founding donors of the NMAAHC. White billionaires, such as Bill Gates, were also founding donors to the NMAAHC, but their rate of giving to the museum-about 3 percent-was smaller than the 100 percent rate of support among the infinitesimally population of blacks in the group. Similarly, of the 20 wealthiest Black Americans in 2009-the most recent year this particular grouping was compiled by Forbes magazine-six, or 30 percent, ended up being founding donors of the NMAAHC. These patterns of funding suggest that wealthy blacks may be more likely than their white counterparts to donate to black museums. Yet, there is also evidence that whites are an important funding base for black museums. ${ }^{11}$ Even in the case of the NMAAHC, where the majority of large donations by individuals, families, and family foundations appear to have come from blacks, gifts from whites, such as gifts in the $\$ 10$ million and above category from the financier David Rubenstein and the Bill and Melinda Gates Foundation, amounted to a significant share of overall funds raised (see Figure 2.1).

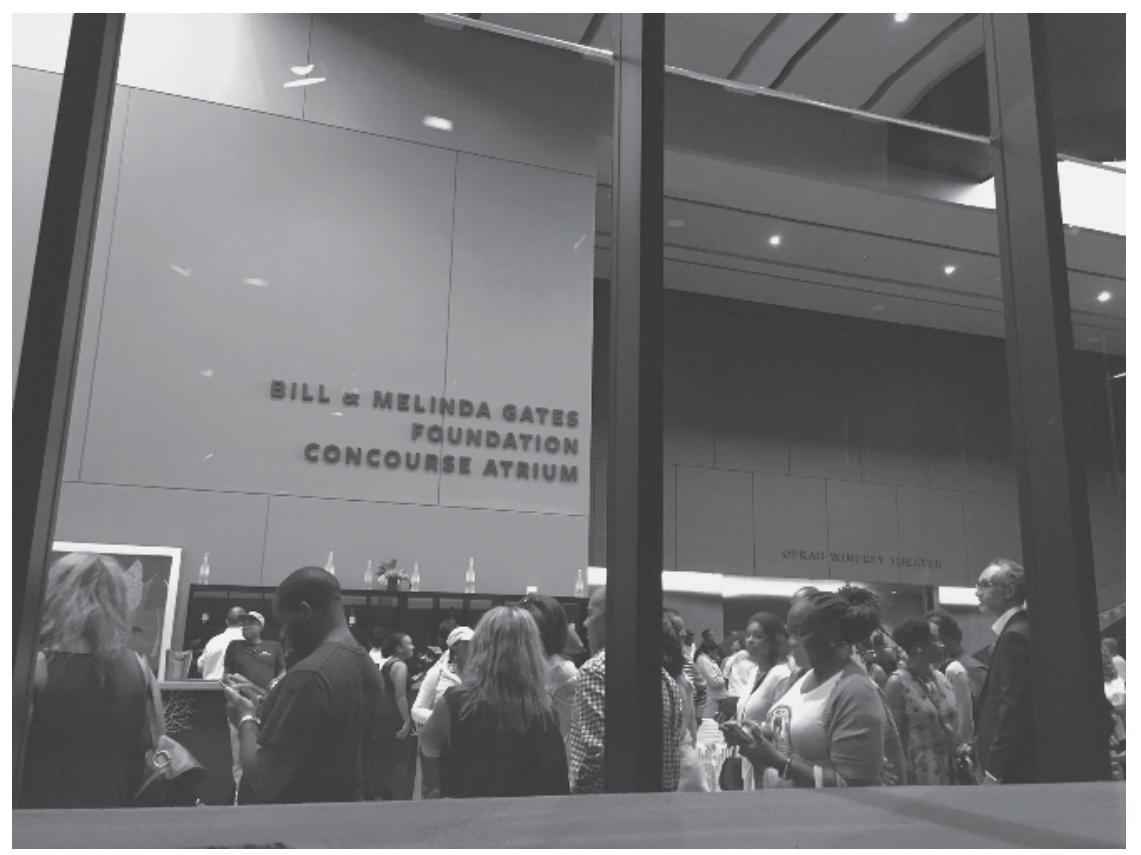

Figure 2.1 Bill and Melinda Gates Foundation Concourse Atrium and Oprah Winfrey Theater, National Museum of African American History and Culture, Washington, DC. 
While recognizing the practical and moral value of white philanthropic involvement, and also helping to secure major donations from his majority white workplace, Don, a black trustee, talks about personally advocating that his racially mixed board not institute a required level of giving for trustees. "A number of the board members-minority board members-felt that it was incumbent upon ourselves to ensure that if the museum is going to be funded, that it is funded from not just the corporate community, but also from the African American community," he explains.

We had a lengthy debate ... two board meetings ago because one of the board members wanted to establish a monetary threshold for board members to give in order to serve. ... But ... I personally thought that it would preclude some people who looked like me from serving on the board. So at the end of the day, the board member who was advocating it withdrew the motion. ... But, financially giving to the museum is extremely important from my perspective, as an African-American, because you can't have what I view as an African American treasure ... and African Americans are not meaningfully participating in the viability of that structure on a go-forth basis. That's not intended to be racist or otherwise. It's just a fact from my perspective. Meaning, that if your heritage is to be preserved, then you need to be a part of ensuring that it is being preserved in the right way.

Given that on average blacks have less wealth and lower incomes than whites (U.S. Census Bureau 2012, 40-41; Oliver and Shapiro 1997), this trustee worried that a minimum requirement for giving might preclude blacks from serving on the board. This concern for black participation in black museum philanthropy is consistent with black middle-class orientations towards not only uplift but also broader black traditions of self-help and giving (Carson 1993).

The question of black leadership also came to the fore as a national black museum in Washington, DC, was being debated. Over the decadeslong process that a national African American museum was under consideration, questions were raised about the appropriate level of involvement for the Smithsonian Institution. Although some of the reticence was grounded in general uneasiness about government oversight, it was also related to specific concerns around race and government control. In particular, there was apprehension that the predominately white leadership at the Smithsonian would marginalize a black museum under its jurisdiction (Brown 1991; Ruffins 1998, 78-101). In the early 1990s, the African American Institutional Study Advisory Committee was formed to determine the feasibility of a national black museum. During the second meeting museum professionals and other stakeholders, such as Tom Mack, an African American entrepreneur, were invited to speak before the committee. Mack played a central role in reigniting efforts to establish a 
national black museum in the 1980s. During Mack's testimony, he raised questions such as, who "should have the power and control over the new institution?" He asserted that the "proposed museum should be governed by the descendants of slaves, rather than the descendants of slave owners" (Brown 1991, 92).

Plans to establish a national black museum in this period ultimately failed, but by the next decade another committee was formed. Although Mack was not on the commission that wrote the draft legislation for a final bill to form the NMAAHC, the issue of black trusteeship was addressed in the legislative outline. The draft legislation stated that a slight majority of trustees, or 13 out of 25, "must be of African descent" (National Museum of African American History and Culture Plan for Action Presidential Commission 2003, 116). The final legislation (H.R. 34912003 ) makes no reference to the race of trustees. However, efforts to legislate the racial composition of the board for what would become the NMAAHC illustrate the concern that blacks will be shut out of the leadership at black cultural institutions.

While some black supporters are particularly attuned to the significance of black participation in the world of black museum philanthropy, it is not uncommon for white supporters to be especially aware of the meanings of white engagement within this realm.

Dan, a white trustee, has an interest in black culture. However, "it's not a passion for me like it is for some people on our board," he says. "That was not really the compelling factor in my decision to do it [join the board]." $\mathrm{He}$ describes his interest in joining this board, as well as the board of another black cultural organization in his city, as motivated by a desire to bridge a racial divide:

I'd been thinking about possibly joining the board of the Johnson [another black cultural organization in the community] because I was attracted to the fact that it was a very diverse board. I hadn't been offered that opportunity yet, but I wanted to get more involved in the city, and I had been involved in other not-for-profits in the city. I was curious about [the museum] and wanted to see it succeed so that was really a big part of it. ... If you know much about the city, I don't know how atypical it is, but the city is pretty segregated. I thought, "Well, maybe there's something that I could try to do about is as an individual." I mean my circle of friends was pretty lily-white, and I belong to an exclusive country club, and I went to an exclusive school. ... But at any rate, that was really more what was motivating me than the values. I enjoy [culture], but it really wasn't the urge that was dragging my interest.

I ask if anything in particular happened to spark his growing interest in fostering racial integration in his community. "No," he replies, "It was kind of a growing awareness. I was kind of involved in community activities, 
but not so overtly in a diverse environment.” For Dan, whose personal network is predominately white, joining boards of African American cultural institutions presents an opportunity to racially broaden his circle of acquaintances. When entering these philanthropic spaces with high concentrations of blacks, he sees himself as a bridge between racial communities. Grant, a white trustee at a black museum in another city, also describes his experience as a board member as a means of crossing racial boundaries. "So, why did you decide to get involved?," I ask. "Well, I guess that it was a feeling that this was a worthy undertaking that the white community hadn't fully supported and that I thought we should," he replies. "I had some experiences in my childhood, in my younger days, with the black community, that made me want to do it." When I ask him about the moment during his "younger days" that gave him the motivation to support an African American museum decades later, he describes a life-changing encounter when he was a 19-year-old college student. "When I was in college I thought that I was going to become a minister," he recalls:

I spent a summer after my sophomore year in Goldsville [a historic black neighborhood] at something called the [East Goldsville Protestant Parish], which was a group of four storefront churches. ... I spent August living right in the community and it was tough. It was tough living in those days. ... But, I found people that were just very, very genuine and very hardworking and good people. I don't know that it changed my view. It may just have really sort of reinforced my view that the white world didn't really understand the black world and appreciate its strengths.

I ask Grant about his social connections to other patrons at the museum. Outside of the museum he does not have a relationship with most of them. "I think that being involved with the museum has brought me into contact with a lot of people I wouldn't have otherwise known," he comments. "Why wouldn't you know them otherwise?" I ask. "Our worlds wouldn't have crossed," he replies. Grant elaborates on the separate spheres of the black and white elite in his city when we talk about one of the museum's signature events. "Far and away the winter gala is the biggest fundraiser," he says.

GRANT: But, that's really attributable to Mary Weaver [a black trustee who works in finance], who has been our board chair for the last, she would say, too many years. She keeps saying she's not going to do it anymore. But, she's a dynamo and because of her work she has connections to people who are involved in very substantial investments. She is a major partner of something called Sound Investments. I have the impression that it's a lot of African American money. You know, it saddens me because it seems to be something that separates the two worlds in a very large way. She's very successful, but most of my friends or acquaintances who are in the investment world, they have no idea. 
PATRICIA: About the company?

GRANT: Well yes, about her organization and how much they're doing. It's been written up in black magazines, many of which I had no idea about. I didn't even know they existed. But, it's a shame that somehow we don't get together. I am hopeful that President [Obama] will somehow be able to bring us more together.

Later, when discussing his contributions to the board and recruiting new members, Grant talks further about the separation between blacks and whites in his city.

GRANT: I don't have as many connections with the African American community, which is really the source of most of the board members. I think that's the way people want it. So, I don't really have many suggestions for new board members. I feel as though I'm deficient in that regard, but understandably. But, I think that I helped to get it [the governance committee which he chairs] together and make sure that we do follow the by-laws and that we grow it. We have an increasingly strong board. The organization has grown immeasurably in strength, in vitality, in financial security, and in the caliber of the board. I'm very impressed with the people.

PATRICIA: What do you look for when bringing people into the organization? GRANT: Well, I tend to look for commitment and a willingness to work. ... I really don't ... know enough about most of the people. I feel very sad that there are two parallel societies here. I think for the most part the white community doesn't understand that the black community is every bit as intelligent, educated, you know all those virtuous things. And, they just go on side by side without many overlaps. It really bothers me and saddens me.

PATRICIA: Do you think that's changing?

GRANT: Well, it hasn't really in the sense that we've only had, as long as I've been there, I think two non-African American board members. Given what the organization is about, and where it came from, it seems to me that that's probably the way it will be for a while. Maybe we should be trying harder to get others involved, but I do think that the leadership of this effort is invariably going to be the people who are closest to this.

Grant enters a black social world through giving to the museum. Not only are the people new to him for the most part, but the broader contexts that encapsulate their lives, such as black businesses and black media, are also not a part of his everyday reality. In contrast, black patrons are often wellacquainted with the people and contexts. For them, patronage at African American museums is a space where they can interact with others who have more intimate familiarity with their lives. 
The feelings of distance that some white patrons like Grant experience at African American museums reflect the very real boundaries between the white and black elite in the United States. However, there are also white patrons who are deeply embedded in the black community. For them, interracial ties forged at African American museums are appreciated as a typical rather than exceptional instance of personally bridging racial boundaries. For example, one white trustee attributes his being asked to join a local black museum board to his "special relationship with the black community." "My high school was 50 percent [black] and ... most of my employees ... are African American," he says. "Now in my adult life, even beyond my business, in all other aspects, my civic engagements, my charitable engagements, I intermingle with every level of the African American community. So, I am very comfortable with African Americans and empathetic."

Patronage events at African American museums are unique spaces in the broader cultural and philanthropic worlds. In "majority" spaces black patrons are typically in the minority, and they often have fewer social ties to other supporters than do their white counterparts. ${ }^{12}$ In the African American museum space, they are more often in the majority and highly socially integrated. On the other hand, when white patrons become involved in black museum philanthropy, they enter a context in which they are more often in the minority and other patrons are new to them. Still, there are some white supporters who often place, or find, themselves in contexts in which they are one of few whites, so crossing racial boundaries in the space of black museum philanthropy is a familiar experience.

For some white supporters, philanthropic involvement in black museums is understood as worthwhile not only because it allows them to actualize personal values concerning interracial ties, but also because it helps museums to meet external expectations for diversity. Some large funders have instituted implicit expectations or explicit requirements that grants will go to only nonprofits with diverse supporters (Bertagnoli 2012). Although these initiatives emerged mostly out of concern for limited racial and ethnic diversity at majority nonprofits, this new emphasis on diversity also affects black nonprofits. Board diversity is now a standard used to judge all nonprofits, with the belief that if they are not racially and ethnically diverse, they are not only in conflict with democratic ideals but also will function at a suboptimal level (Parkinson 2016). Some white supporters recognize that their presence at black museums addresses the pressure for racial diversity. One trustee notes this when he describes how he is often asked to participate in highly visible events, such as visits from dignitaries, at his museum. Reflecting on these events he says in jest, "So pardon the crass description, but I was like the white busboy because they always needed, they wanted diversity." He enjoys the events, but also recognizes that his whiteness signifies to the broader community that the museum is racially inclusive. Similarly, after mentioning that he's "the only white guy on the board," a patron at another museum describes how white supporters signal to the 
philanthropic community that black museums are in line with new diversity norms. He notes that in "management audits conducted by museum associations," typically the critique is, "You're all white. You'd better do something about that." But, in the case of his museum, it is, "You're all black and you better do something about that."

Okay, fine. They say in order to be successful you need to have a diverse board. If it's all black, it's not going to work. You really need to, regardless of the thematics of the institution, to reflect your community. But I'm very comfortable with it, if everybody else is. Whites, blacks, so that's cool.... It's really a question of do you bring the management and the leadership expertise to the issue to make the place successful. And I've never run into any issue, at least over anybody saying, "What's that white guy doing down here?"

Some white supporters understand that their involvement in black museums helps the organizations to comply with values emanating from the broader nonprofit environment that idealize, and as one patron notes, almost "fetishize" diversity. Although this is not a major motivator of their involvement, it is nonetheless a role that they recognize themselves playing by virtue of their race. White supporters are often entering spaces where they may be "temporary minorities," or at least much less in the majority than they are in the philanthropic space of majority cultural institutions. ${ }^{13}$ For many, this contributes to a heightened sense that what matters about giving to black museums is that it can be a site where racial divides are bridged. Next, I describe differences in how black and white patrons define the racial value of black museums in relationship to place.

\section{Places}

From the earliest years of the black museum movement, many African American museums, such as the DuSable Museum of African American History in the South Side of Chicago and the Studio Museum of Harlem, were established in black communities. In this way they are not only spatially close to where African Americans live but also part of a broader network of black institutions such as black churches, black schools, and black-owned businesses. Some black patrons view support of their local black museums as strengthening these spatial and symbolic black communities.

Kwame is an entrepreneur who lives and works in a historically black neighborhood. He moved to the neighborhood with his parents and siblings several decades ago. Though the neighborhood is now gentrifying, he sees the area as a model self-sustaining and self-sufficient black community. To him, it is a place where black nonprofits, like the museum where he is a trustee, along with black-owned businesses like his own, can thrive and contribute to the well-being of the still primarily African American population. 
Everything that he needs, as he says several times during our interview, is "within a one-mile radius." Kwame first became acquainted with the museum and its founder when he was growing up. It is part of a cultural center where his sisters, and later his daughters, took dance lessons. It's “only a block and a half away from where I live, so it's also in a one-mile radius. It's part of the community," he explains.

Several years ago, Kwame was approached by the museum's founder to do some sales-related work with the museum. In keeping with his philosophy to donate part of his business profits to community organizations, he made a gift to the museum after his work was complete. Subsequently, he was invited to join the museum's board. As Kwame talks about his initial work for and then subsequent donation to the museum, he describes his philosophy of black economic empowerment. "Well, typically when I make a sale, particularly if it's a large sale, I like to make a donation to the charity of the sellers' choice just ... to be appreciative of what they allow me to sell, to try to increase business for black businesses," he explains.

I take and then I give, because if I take and then I give, all of the money stays in the same circle and that's very important. So it may be small, but it's very important. My first sale was to an attorney. Then I made a sale to an electrician. I got the electrician to hire the lawyer to represent him ... and then I got the lawyer to hire the electrician to do some work in his house. So even though it might be small, the idea is not. And, when you continue and you get larger, it has more of an impact. Particularly the impact is felt if you stay in that small circle. If you do things 10 or 20 miles away from you it's not felt the same as when you do things within the small circle, because you can actually measure and see the quality of life changes. And, it can affect your personal quality of life and that was my goal.

There is a proposal to move the museum to a new area in the community. Since it is still within the boundaries of a one-mile radius, Kwame is not concerned about the move:

I am a local yokel as you might say. I am a local guy. I believe in living my life within this radius, taking and giving in the same radius. The reward that I receive is that I can actually see the effect because it's in such a small area. ... If you walk around the street you might see someone who is addicted to drugs come up and talk to me and you might see a minister, or a politician. There is a lot of love and a lot of respect when I walk down the street with my neighbors. ... I am happy to have the wealth that I have. Whatever wealth that I have, I attribute it to the same inner-circle one-mile radius. But, the money was not my goal. The goal was improving life, not being humiliated. That's very important to me. It's very important to me as a kid who grew up in 
the Jim Crow South—separate water fountains, back of the bus, being yelled at by people. I am a child and a white man is yelling at me about walking to the wrong bathroom. Those experiences of hate make me say, "Okay, you keep this. You want this. You got it. This little square right here belongs to me. Whoever steps on this property has to submit to my way of life and my way of thinking." And, I am going to do the very best that I can to make this square the very best that it can be.

In Kwame's eyes, supporting institutions in black neighborhoods helps to ensure that black people, including his own family, are able to enjoy a good quality of life in communities where they are subject to less racial discrimination and stigmatization. He emphasizes that his priorities for giving are to "myself and my family first, and the community in which we live because it's our home." "If I am not going to go out, then I must make change within if I want a better life tomorrow," he explains:

How do I make life better and avoid the indignities and humiliations that we suffer as a people when we are in the larger community? I would rather stay here with dignity and just cure the ills that are here as opposed to trying to change the larger community. That's going to be an everlasting task for us as a people and we are still trying. Our president [Obama] is humiliated. This guy is getting insulted and humiliated by all kinds of people, and here he is a fellow that graduated from a prestigious university and he's articulate, he's smart, he is honest... And so myself, I try to avoid these things that the highest person in the country suffers. To avoid this, I said, "Well, I will resort to just staying right here in this little village and make the best of whatever it is for me to have." And for me, it works.

In Kwame's eyes, the African American museum where he is a trustee is part of a broader black neighborhood ecosystem. By supporting the museum, he is also supporting a spatial and symbolic community where he lives and works. He regards the space outside of his gentrifying, but still predominately black, neighborhood as one where blacks are at risk of discrimination and stigmatization. By supporting black organizations, such as the African American museum, he sees himself as nurturing an oasis where blacks not only have shelter from racial humiliations and slights but also can enjoy the company and talents of one another.

Other black patrons with long-standing ties to the black communities where the museums that they support are located also describe the museums' value as community institutions. Some patrons do not actually live or work in the communities but they have other ties, such as growing up there, having family who live there, or attending church there. A black trustee who does not live in the black community where the local black museum she supports is located but has gone to church there for over two 
decades, describes the role that the museum plays in the broader neighborhood ecosystem - particularly for black youth. "So many kids still don't get beyond a certain geography, and certainly, having a black museum dedicated to art opens up their world of thinking about 'Well, there's more out there,'” she reflects.

While black museums are often founded in black neighborhoods, some communities later undergo a shift in racial makeup. Over time, the museums can end up being on the edge, or in the heart, of gentrifying communities. These shifts in racial composition are often part of broader city transformations where the communities are targeted for redevelopment. As is the case in cities around the world where art and culture are used to spur local economies (Dávila 2004, 2012; Grazian 2005; Lloyd 2010; Wherry 2008; Zukin 2014), black museums are sometimes also part of redevelopment plans. Some black supporters with long-standing ties to these communities welcome improvements to the neighborhoods and an infusion of resources to black museums as part of neighborhood revitalization. However, they also express nostalgia about black neighborhoods of yesteryear. Cynthia is a trustee who spent her early childhood in the segregated neighborhood where the black museum she supports is located. She reminisces about that period, recalling, "Folks were just out strolling and eating and having a good time, going in and out of the [black-owned] restaurants." When she describes how her trusteeship at the museum fits into her philanthropic ethos, she elaborates on what she views as an unintended positive side of past segregation. "It's [her philanthropy] all about the empowerment of our people," she explains:

I think that unfortunately we are having vivid demonstrations right now that what used to be just the way it was-that parents taught their children coping skills in order to make it in essentially a white world-a lot of that kind of fell off for various reasons. I think integration sent a false message that we didn't have to still know how to successfully navigate American culture. So, we saw a lot of our people become so frustrated and so disengaged and then the whole drug phenomenon. So, helping people with coping skills, and also helping them to develop sellable skills is something that I've always been a part of. ... So, as I look at my history of boardsmanship, it's always been about that. I think that our museums are ways to showcase who we are-the excellence, the passion, the beauty, the expression, all of that that is resident in our society. ... So that's one of the reasons that I really enjoy supporting the whole museum piece.

Currently there are efforts to revitalize the community where the museum is located. "I think it's very important," she says about the effort. But, she also questions whether the revitalization has to come at the expense of undermining the black fabric of the neighborhood: 
CYNTHIA: As you know, you can go all over the world, and if you say something about this area, there's a really good chance that the people you're talking to in these foreign locations have, at the very least, heard about it. So when you have something that valuable that is yours, and is physically located in your space, it needs to be viewed and treated that way. That's something that I think we need to do more work on.

PATRICIA: Do you expect the character of the community to change if there is more government and business investment in the area surrounding the museum?

CYNTHIA: I don't think that positive recognition and improvement has to necessarily be because gentrification has occurred. I think that too often it's viewed that way, which is why some of the older folk who remember the heyday get upset. Because it's like in some folks' minds, the only way that it can be improved, upgraded, raised to a higher lever-in the eyes of the general population-is that it has to be whitened. While that's a belief held by many, that doesn't have to be the reality. The reality should be that there is a richness and something worthy of understanding and embracing without you changing the culture, and without you changing the overarching physical makeup of the people who are there. So yes, I want us to be and to remain inclusive, but I don't think that we should have to subjugate the African American culture that founded it in the first place.

PATRICIA: What would it look like if you subjugate the culture?

CYNTHIA: Well, this is where you would have mainly white ownership of the businesses, where the music would be aimed particularly at the preferences of a specific audience. It probably would be where you would have more of your chain outlets up the street, as opposed to individually owned and flavored retail outlets, where a lot of the leadership of different things would not be as integrated as would be desirable.

Some other black supporters are cautious about change in the neighborhoods where the museums they support are located not because of personal memories of days long past, but because of the memories and experiences of blacks in their network. "I didn't grow up here. I don't work here. I live on the other side of town," one supporter notes. "But, I have close friends who make their living here and call it home. They've been here their whole lives. Change needs to happen and [the museum] should be part of it, but black people shouldn't be left behind."

Ben, a black patron who lives and works near the black museum he supports, also expresses caution about ongoing changes in the neighborhood. "This is my hood. I love it-born and raised," he says. The community is undergoing significant demographic shifts, and the museum itself is framed by some stakeholders as a vehicle that can help to enliven the local community and its cultural infrastructure. However, Ben wonders if the changes will compromise the cohesiveness and even physical and emotional 
safety of the area. "This is my community. I wouldn't trade it. I love being in the 'hood," he says:

No matter how much money I make, I feel safest here. I will try to develop my own 'hood as opposed to going around people who are working against my interests without even knowing. When you leave, when you go to spaces that are not safe, some of the people there are against you without even realizing and that's very, very dangerous.

He elaborates on safety in the area around the museum. "I would rather go down to the museum by the projects. I feel safer in the 'hood than I do in the Heights [a wealthy white area]. I went to school there [the Heights] and felt completely unsafe, but the 'hood is fine."

PATRICIA: So what do you mean by unsafe?

BEN: Well, when you are walking down the street and someone looks in your face, and you can tell that they don't necessarily see you as a human being. Just things like that and all of the other microaggressions that accompany it. That's what I mean by unsafe.

PATRICIA: So in this predominately African American space you don't get that? BEN: No. If somebody has a problem with you, it's probably because they have a problem with you particularly and not just because you exist. I'll live with that.

PATRICIA: Do you think that gentrification will alter the demographic profile of the museum's supporters?

BEN: I doubt it. I mean, the community has changed. Many of my neighbors are gentrifiers. However, you're not going to see them heavy in support [of the museum] because they don't care about it. When a hipster coffee shop opens, they flock to that because that's what they want to support. They're looking to support another hipster coffee shop, but they're not looking to support the museum. They are not looking to support [the museum] because they don't care. Because it's not theirs, they see no value. It doesn't mean community to them. It means nothing. So, I don't worry about the demographic of the museum changing too much... They [the gentrifiers] are not here to interact with the community. They are here to create their own community. They are not interested in acknowledging the lady that everybody for twenty years says good morning to. They are not interested in that. They are not interested in supporting and seeing how they can build these small businesses over here. They are interested in creating their own small businesses in their place. They don't see value and that's why the demographic of the museum won't change. Whether or not the museum exists in five years or ten years, that's the question. While it's here, the demographic is going to be the same. The same people are going to be supporting it. 
Ben sees the new residents populating his neighborhood as having little commitment to either its well-established black institutions, such as the museum, or its long-standing black residents. In his view, they also make the neighborhood less safe. "As the numbers grow and there becomes fewer black people and more gentrifiers, it is less of a safe space," he comments:

You know, when my neighbors are having a party I just try to go to sleep. I deal with the noise. I am not calling the police on my neighbors when you know they can experience violence. I've sat in community board meetings and just hear people, new residents of the communitygentrifiers-casually talk about calling the police on business owners or residents. There's a code here. You don't do that. You might as well hate somebody to do that. You could possibly be sentencing them to death by doing that, and so, no, it's not as safe anymore. It's not as safe.

Although Ben has lived in this community all of his life, his comments are resonant with middle-class blacks who move to black urban communities partly to seek respite from racial marginalization (Pattillo 2007). In his research on "the continuing significance of race," the sociologist Joe Feagin catalogues a range of discriminatory actions faced by middle-class blacks in public spaces. They include behaviors such as verbal epithets, poor service, and police harassment (Feagin 1991, 104). It is microaggressions and more explicit forms of intimidation like these that Ben feels less exposed to in the predominately black neighborhood where he lives and where the museum he supports is located. While some of these communities also suffer from challenges like declining infrastructure and crime, to a degree they serve as an oasis from some forms of racial marginalization. Black supporters like Ben with strong ties to these areas are often intimately familiar with these protective qualities of black communities. For this reason, some are wary of the gentrification taking place in the neighborhoods surrounding black museums.

For white supporters, who often have a very different relationship with these neighborhoods-one not atypically anchored by weak ties and entailing passage across an unofficial racial line that circumscribes the black side of town-it is not uncommon to be especially focused on the role that black museums can play in building interracial community spaces. Dan, who became a black museum supporter to help foster interracial ties via the board, also sees his museum as a vehicle that can do this more broadly by "helping with diversity in the community." Before he joined the board, he personally spent little time in the predominately black neighborhood where the museum stands. But he thinks that the museum can be a draw for whites to visit the community. He tries to bring white friends and colleagues to the museum as a reminder "that there really is a very strong cultural heritage here." 
It happens to be an African-American heritage, but it's an important heritage for the city, and I think a lot of people don't really appreciate it. ... I bring people down to the area on occasion. We have an annual fundraising luncheon ... preceded by tours of the museum, and it's been fairly effective. I bring people to that luncheon and so it's on an anecdotal basis, but maybe it's somewhat helpful.

While his friends and colleagues have generally welcomed their sojourns to the community, he recalls one disheartening response.

It's almost uniformly positive, but there are friends of mine who clearly live extremely suburban lives and are not accustomed to being in an urban diverse setting, and it's kind of disappointing to me. There is really one guy who I could just tell he hadn't been around African American people much. I mean he's been in business for years, but at any rate, I got him down there. Of course he doesn't know [the culture] so there was that aspect as well. So some people, it's just going to take a while. But most of the people, just about everybody else I've taken down to the museum, have really been surprised and enjoyed it.

Dan sees fears about neighborhood crime as one reason that some whites are reluctant to visit the area. "Where it is [the location] has a lot to do with it," he says. "There is still kind of, I am sure you run across it talking with others, this kind of concern about coming down to the inner city." Gregory, another white trustee, also describes how segregation in his city-and white perceptions about crime in the black part-deter white visitation. "It's part of the race problem that exists in the city," he says.

I think there are people who don't want to go east of Walton in the city and who are afraid to go to the [area around the museum]. That's part of it... In a lot of communities, particularly white communities, they don't really think about even venturing down there, except to go to Jake's [a popular restaurant]. ... I don't think it [danger from crime] is really a reality at all. But, there's a perception whites in the city have.

In his opinion, improved transportation that better integrates the black neighborhood with the city center, as well as more parking spaces near tourist attractions like the museum, will help to bring more traffic to the area.

I think you've got to make it easy for people to get there and feel like it's more of a controlled safe environment.... I think that [better public transportation] would turn that place around. If you just had a simple easy way to get over there.... Parking is sort of unclear in the neighborhood. I mean you're looking for parking spots in the street, and people 
don't want to stray far from [the main thoroughfare] and so I think that's an impediment.

John, who is also white, similarly comments about crime as an impediment to whites visiting the black museum where he is a board member. He does not live or work in the black section of the community where the museum is located. But, over the years, he has visited the area for its cultural attractions. Even before he joined the board, he made these sojourns. "I loved the diversity that was evident when you came here," he reminisces. "I always found that intriguing and I don't know why. But, I liked being immersed in a different culture. I felt super cool. What can I say?" Compared to the past, he sees the community as less "edgy" but safer now.

It's less edgy now, because it's more mainstream now. I don't feel the least bit threatened when I come here. It's very different now. Typically, when we [his group of friends] came to a club we would be the only white folks in the club. I didn't necessarily feel really safe here at the time. It's changed now because it's more gentrified, and there's a lot more substance here than there was then.

Despite feeling that the area is now safer, John describes how some white acquaintances are wary of the community because of concerns about crime. "Now, I'll tell you a story that I found very interesting," he recounts.

I was interviewing ... a white guy who's probably in his forties-and this is really kind of disappointing to me. He told me, "I was walking down the street with my son and I was on 11th street. As I passed Matey's-[a restaurant near the museum] —I realized, oh, oh, I'm getting over near Charles Street [the street the museum is located on], we need to turn around." He said, "I didn't want to make a big deal about it with my son, but I knew we had ventured too far." I thought, "No, you hadn't. You hadn't ventured far enough." But that's still something that we fight. ... I've had people tell me, "You know, you just need to move the museum over to a different area and it would flourish. You need to move it five blocks west of here." Well, that isn't going to happen. This is a [historic site], not five blocks west of here.

"Do you think that it [the museum] would thrive if that [moving the museum] was the case?" I ask. "I think it would do better ... but I'm not in favor of moving it," he responds.

But, I'm also not going to discount the fact that it's a hurdle that has caused some difficulty. ... Over the course of the years I've probably brought twenty people in. My hope would be that someday, when they're looking for something to do, and they've got guests in town or 
something, that they'll think about coming over here and that begins to break down the concerns that people have. The other thing that happens, that sets us back, is there have been shootings here. ... I've had people tell me. "So, how are things down there? Have you bought cocaine down there lately?" Well, you know I don't like hearing that, but that's what people do.

Right now, the community is transforming with more business and government investment. While these changes might shift the racial demographics and cultural spirit of the neighborhood, John sees them as improving the life chances of residents and bringing broader support to the museum.

As far as changing the area I guess I'm all in favor of making it a vital area. ... I don't care if it's strictly a black culture place, because I believe over time the cultures have to begin to meld. Hopefully, we'd always have the uniqueness of the culture. But, at the same time, I'd like to think that the cultures begin to blend a little bit better and with that you probably are going to change the area. But, I don't see that as a problem in the long term.

Other supporters echo his belief that though segregation helped to create unique black cultural traditions, gentrification will ultimately be a positive development for the community's people and organizations. One white trustee, who says he was a "casual appreciator" of the neighborhood prior to joining the board, favors investment that he hopes will bring in more tourists and others. "It was a fully thriving community, and then for a variety of reasons it went into ... a sort of fallow, nonthriving state," he says.

We can't bring it back, nor should we even think about bringing it back as an engine of black life. ... No way, we bring it back as a connected part of the city that people use and enjoy for what it is, whether it's nightlife, or business areas, or the historic research that can be done in the museum. So we bring it back that way. That's really the path that we are on now, which is really exciting.

Jacob, a white trustee who describes himself as "just peripherally" linked to other organizations in the historically black community where he is a museum trustee, is also enthusiastic about neighborhood revitalization there. Although he is an avid supporter of revitalization efforts, he recalls a news report in which black residents voiced concerns about gentrification. "People think it's the wealthy people just coming down here and wanting to take over.... It's from my vantage point totally irrelevant and not true," he says. But, he admits that "there's a lot of history, things that took place 30, 40, 50 years ago. Things that I barely know about." In his eyes, business investment will increase visitation to the museum and improve the 
community as a whole. But, he fears that businesses will come only if more government funds are directed to the area.

If you come down here, you see structures that don't look good. They don't look stable. A commercial developer looks at that and says "Am I going to be able to succeed if I come down and start a restaurant or start a dry cleaner, or whatever?"

Ultimately, he believes that the museum's future depends on fully integrating it into the city's "business and tourist infrastructure."

These white supporters are especially attuned to the role of black museums as vehicles for building interracial communities. While many do not have deep structural ties to black neighborhoods, they typically see their interactions in these areas as positive and encourage other whites' involvement. Being exposed to unfiltered fears from white friends and acquaintances that black neighborhoods are dangerous, they are also particularly sensitive to the reality that white visitation to these museums may be held in check until concerns about crime in the surrounding neighborhoods are allayed. In their eyes, gentrification is a tool that will help to increase museum visitation and improve the quality of life of residents. Among black supporters there is also strong interest in infrastructural changes that will upgrade black museums and their surrounding communities. Black supporters are also typically keen on creating a museum environment where all people, regardless of race and ethnicity, feel welcome. However, they also more often have a heightened awareness, derived from personal experiences and the experiences of black family, friends and acquaintances, of racial marginalization that can accompany gentrification. Moreover, personal experiences within, and collective black memories of, self-sufficient black communities of yesteryear also contribute to deeper nostalgia for thriving black communities. In the next section, I compare how black and white patrons define the value of black museums in relationship to racial and ethnic narratives.

\section{Narratives}

Tucked into a corner on the third floor of the NMAAHC is a white sign with maroon writing that reads, "Mae's Millinery" (see Figure 2.2). The surrounding glass cases are filled with intricately designed hats and accessories created by Mae Reeves. In 1941, after moving to Philadelphia from Georgia during the Great Migration, Reeves opened what would become a thriving hat shop. Her grandson Joel Limerick was partly motivated to join the Ambassadors at the NMAAHC - a young professionals patron group for individuals who give between $\$ 5,000$ and $\$ 24,999$ - because of the familial connection (Building Blocks 2014). Commenting on his patronage he notes that, "This is a chance for us to be part of something that generations after us will thank us for" (Building Blocks 2014). 


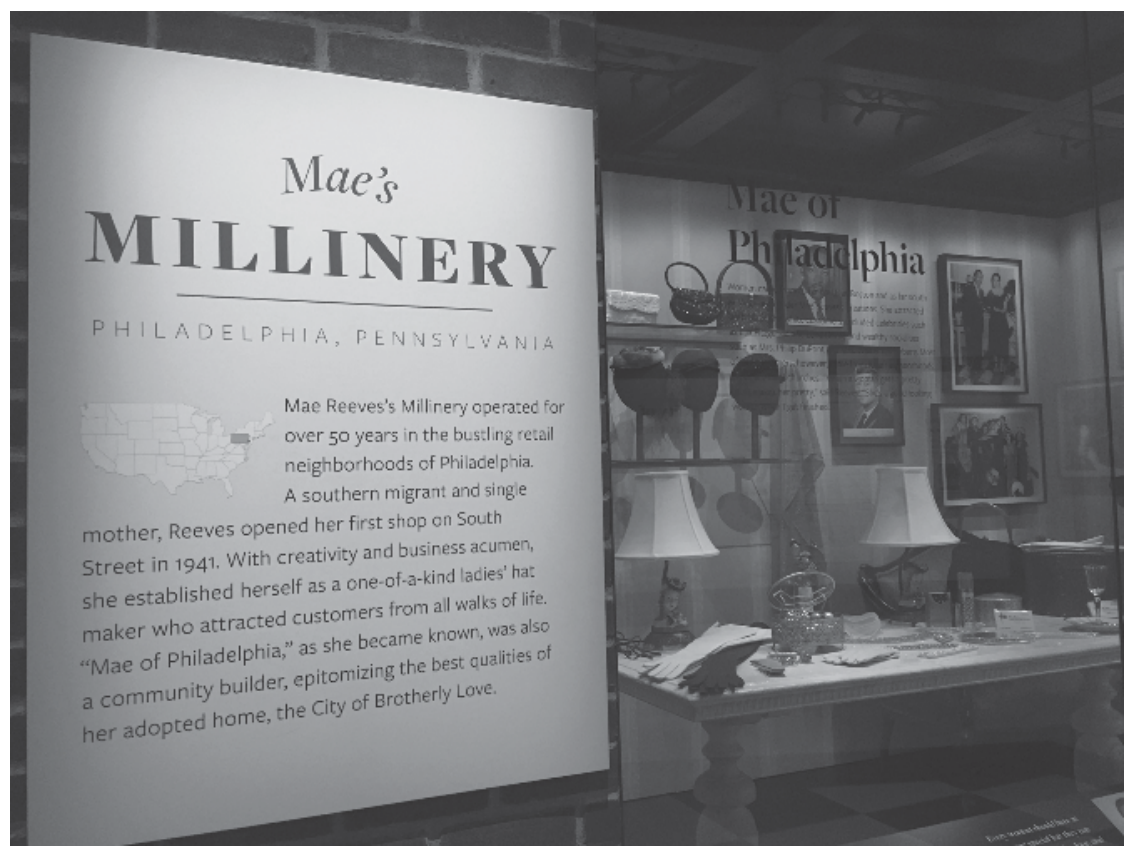

Figure 2.2 Mae's Millinery Exhibition, the National Museum of African American History and Culture.

Black supporters often describe the value of black museums in relationship to preserving personal histories characteristic of the black experience. While they may be intimately familiar with family histories and have held onto cherished family heirlooms, they view black museums as spaces that can protect and publicly memorialize these legacies. Donating or loaning family artifacts to, and providing financial support for, African American museums allows them to help preserve these legacies. The Boyd family not only gave a million-dollar gift to the NMAAHC, but they also donated artifacts from their family business started by Richard Henry (R.H.) Boyd in the 19th century. The family history is documented in an exhibition in the museum's Community Galleries. At the top of the exhibit case there is a quote from the family patriarch, the publishing magnate R.H. Boyd, that reads, "Will you help the young Negro be a self-respecting man by putting the Periodicals of his father's organization in his hands?" The display holds objects such as a black-and-white family portrait from the 1890s, a metal printing plate used from 1959 to 1979, and a printed Baptist Sunday school lesson from 1926. T.B. Boyd III, R.H.'s great-grandson, describes the personal and broader cultural significance of his family's heirlooms and philanthropy at the NMAAHC (Smithsonian Campaign n.d.): "We need a repository for African American 
history in this country. A lot of our great stories have not been told ... I grew up with these beautiful artifacts. Now, they'll be shared by millions."

These family stories, often involving success against the odds, are embraced as personally inspiring narratives that can also motivate a broader public. When I interviewed black supporters in their homes, they often showed me heirlooms that serve as aide-mémoires for recollecting family histories. Some patrons also display these objects in their offices. After I interviewed one black trustee in a conference room at his family business, we went upstairs to his office. A copy of a cherished 19th-century family document hangs on the wall there. He went over the history of the document in detail. In the process of describing this artifact, he told a broader story about his family's upward mobility, mentioning "several generations of college-educated folks on both sides and ties to Booker T. Washington." "Looking at people like my ancestors ... that history insulates you," he says.

Once you understand that kind of stuff, it allows you to deal with all of these other modern challenges. ... Whenever we have some challenges [in the business], I just look at this up on my wall.... You look at that, and you say, "Wow, these guys did incredible things, and we can do it as well." Not in any way standing others up, but it has to make you feel good about yourself.

For black supporters who deeply value tangible and intangible family cultural patrimony, African American museums are often lauded as institutions that can aid in protecting and preserving it. There is often recognition that these narratives and objects are among a sea of others relating to African Americans that have been largely hidden from public view. However, there is also often the belief that if these artifacts and narratives are introduced to the public they can empower others, just as they have been a source of inspiration and strength in their families. While these narratives and objects that center African Americans are valued for how they can empower all people, there is often a particularly clear and concretized understanding of how they perform this function for blacks. Black patrons' personal experiences, and the experiences of their families, give them intimate knowledge of how they can motivate and embolden African Americans.

The cultural engagement of Michael Moore, the president and CEO of the International African American Museum (IAAM), helps to further illustrate this point. Moore is a direct descendant of Robert Smalls, a politician who served in the South Carolina legislature in the middle to late 19th century. Smalls, who was once enslaved, gained fame and recognition after commandeering a Confederate ship and sailing to freedom. Moore's family has preserved his legacy through helping to produce a traveling exhibition that has been shown in museums across the United States, including the Museum of African American History in Boston. Moore references this family legacy when talking about fundraising for the multimillion-dollar IAAM (Knich 2014). The 
museum will stand on the shores of Gadsden's Wharf in Charleston, which was an entry point for an estimated 100,000 enslaved Africans. Most African Americans today, including Moore, likely had an ancestor pass through there. Robert Small's enslaved grandmother is believed to have taken her first steps on Gasden's Wharf. Knowledge about his family history helped to strengthen Moore as he was growing up in the 1970s. "Having a connection to Robert Smalls really was a great counterbalance to help me kind of feel a little bit better about my identity and everything," he says. "But, there are a lot of those stories. We just need to tell them" ("Michael B Moore" 2016).

The black billionaires Oprah Winfrey and Robert Smith, the two most generous donors to the NMAAHC, with gifts in the category of $\$ 20$ million and above, also discuss their gifts in relation to African American pride: "This museum says that we African Americans are at the center of it all," Smith says (Alexander 2016). Winfrey comments similarly,

Everybody will get to hear how there's a shared story we, as African Americans, all have. And we'll get to see ourselves rooted in that story in such a way that it can do nothing but lift us to be better and to do better.

(Davis 2016)

The basketball star Michael Jordan also describes his gifts to the NMAAHC in the frame of collective black pride. His \$5 million donation was memorialized in a named section of the sports gallery, the Michael Jordan Hall: Game Changers. He also donated his 1996 NBA Finals jersey to the museum. "I felt it was an honor to get involved with the museum," he said about his gifts. "It's going to be a special place, one where African Americans can take pride in our heritage, kids can learn about our history, and were we can find hope and inspiration" ("Game Changer" 2016, 7).

Winfrey and Jordan are not alone in noting the importance of African American museums for black youth. Some black patrons, especially women, describe patronage of African American museums as part of their personal efforts to socialize their children to develop positive black identities. This inclination falls in line with findings in the literature on black middle-class families, noting that the positive racial socialization of children is a common child-rearing goal (Banks 2012; Barnes 2016; Tatum 1987; Lacy 2007). Marion Hawkins, a mother of two young girls, talks about why she and her husband decided to donate to an African American museum in their community. After learning about the fundraising efforts through her job, she later discussed making a gift with her husband:

I went home and I said, "We have to do something. We have to do this. We have to get involved." And of course he [Martin her husband] signed on. "We have to do this for our daughters," he said, "and our legacy." So that's how my initial participation came about. 
Ultimately, the young couple decided to give $\$ 25,000$ to the museum. Marion describes how an ethos of racial uplift, along with a desire to ensure that her daughters have a positive self-concept and understanding of their cultural heritage, motivated the family's gift.

Racial uplift has been kind of drilled into me from a young age. Attending an HBCU, you know how it is, it's drilled into you every day-not only by your family, but by the professors, by your community-that we have to uplift our race. ${ }^{14}$ We have to continue to do whatever we can to uplift our race and to help our race, no matter what. So growing up, Martin and I just believed that wholeheartedly. ... We live in the Dotson area. It's very segregated, not very diverse at all, and Melissa [the couple's oldest daughter] is the only African American in her classroom. Sarah, our three-year-old, is the only one in her preschool as well. Growing up, I was one of maybe two or three in the Advanced Placement classes, and it was the same with my husband. He was maybe one of two or one of three. That was one of the reasons why our parents were like, "No, you're going to [an HBCU] because you need that foundation first before you go on to [graduate] school." So, because our children are growing up in kind of similar circumstances in terms of being "the only" in classroom settings and camp settings, it's important for them to get that foundation from us first. We teach them. We read to them. ... This [the museum] is the only place they're going to get it from. So, we have to help build this museum. Not only will they learn from it, but whenever we go into the city and they pass the museum site ... Melissa will say, "That's our museum. You guys are building that museum. They're brown like us." So she knows, and Sarah pretty much is three, so she just repeats what Melissa says. We want them to have that understanding, that knowledge, but also to be proud. We want them to have pride in who they are as African American girls, not only as Hawkins's but as African American girls. As African Americans this is what we're doing to better our race and to not only better our race, but to educate the world about African Americans and our contributions that made this country possible.

Some black mothers' commitment to African American museums as a site of black identity socialization for their children is practiced through involvement with Jack and Jill of America, Inc. Established in 1938, and with chapters across the United States, Jack and Jill is a black family organization for mothers and children (Lacy 2004, 908-930; Graham 1999). It focuses on children's social development and civic engagement. Jack and Jill is part of the broader set of black middle-class social organizations that are engaged with African American museums. Indeed, the national organization, along with one local chapter, gave large gifts to the NMAAHC and are listed on the donor wall. When I was at the NMAAHC opening, I noticed a 
Jack and Jill chapter wearing matching t-shirts touring the exhibits. Other chapters, including the Rockland Orange Chapter from New Jersey, also attended and posted photos on their Facebook page. In one photo, the group is posed in front of the Robert Frederick Smith Corona Pavilion holding a sign with its chapter name. Under the chapter name, the phrase "The Power to Make a Difference" is lettered in cursive. The caption on Facebook reads, "The Takeover: JJROC visited the National African American Museum of History \& Culture in Washington DC. 33 mothers, 4 dads and 37 children (Tiny Tots to Senior Teens)!"

Among black supporters particular emphasis is often placed on the role that African American museums play in preserving, interpreting, and exhibiting heritage that centers and empowers African Americans. There is typically deep appreciation that African American museums also highlight how the history and culture of African Americans is intertwined with those of other racial and ethnic groups, such as whites, and that the heroism of African Americans can inspire all people. Yet, they and many of their forebears have experienced the United States as African Americans, and so black patrons are often especially attuned to the value of African American museums for institutionalizing the history and culture of the nation through a black lens and transforming the black psyche. In comparison, white supporters are often particularly attuned to the interracial dimensions of black museum stories and their relationship to whites' feelings and understandings surrounding race.

There are multiple lenses through which to view the past. All pasts involving people categorized as black can be understood through a lens that makes visible those who are nonblack. For example, Jeff, a white patron, describes his interest in the black museum he supports as related to his broader interest in the Civil War. When he talks about the role of the museum in illuminating the lives of significant figures of the past, each person he names, such as Abraham Lincoln, is white. His interpretation of the past is an implicitly interracial one in that the broader institutional context is black, but his angle highlights white figures. More commonly, the emphasis on an interracial narrative by white patrons is not articulated through implicit black absence but rather an explicit discussion of the interconnections between whites and blacks as a whole, or between specific white ethnic groups and blacks. For example, a white trustee who is very involved in music, praises the museum he supports for highlighting historical patterns of cultural interaction between blacks and whites. "The reality is that black and white people were playing music together," he says.

The image is they never crossed paths. They never played together. Well, they did, and we have a fabulous collection here ... where you can see that the races played together. They were very creative about it. It's about the psychology of us figuring out how to mature our country and come together. In spite of current rhetoric and our political happenings, 
we do a much better job of coming together than we give ourselves credit for, and we will get much better at it in the future.

For him, black museums are notable for telling lesser known stories about the interconnections between blacks and whites. The interconnections between African Americans and whites are also made manifest in a statement from the private foundation of the white hedge-fund billionaire Louis Moore Bacon about his $\$ 1.5$ million donation to the NMAAHC. Bacon, an environmental conservationist, made the donation to support an exhibition about rice fields in South Carolina's Lowcountry. He is a direct descendant of Roger Moore, who owned a rice plantation cultivated by enslaved blacks. In a press release from Moore's private foundation, through which the gift was made, the conservationist's family history on the Orton Plantation is interwoven into the discussion of the gift (Moore Charitable Foundation 2016):

Recent archaeological excavation efforts at Orton Plantation revealed for the first time the remains of the lost Kendal Plantation, a site originally founded in the 1720 s by Moore. The site is also a testament to the heartache, sacrifice and accomplishment of all enslaved African Americans.

By contextualizing the seven-figure gift within Moore's ancestors' involvement with slavery, this statement emphasizes the interconnections between African Americans and Moore's cultural and economic inheritance. Other white supporters emphasize interconnections between white ethnic groups and blacks through their giving. For example, Andreas Dracopoulos, who was born and raised in Greece but now lives in the United States, gave a million-dollar donation to the NMAAHC. He is the great-nephew of the late shipping magnate Stavros Niarchos and co-president and director of his great-uncle's foundation, the Stavros Niarchos Foundation (SNF), which gave a two-million-dollar donation to the museum. The two donations were covered widely in the Greek newspaper the National Herald and announced on the SNF website. In one press release about the foundation's gift, there is a photograph of Dracopoulos smiling and standing next to Kobe Bryant, who is also seven-figure donor to the NMAAHC. Dracopoulos's personal gift and the foundation's donation were made to honor Archbishop Iakovos, the former primate of the Greek Orthodox Archdiocese of North and South America. ${ }^{15}$ Iakovos, who was involved with the civil rights movement, marched with Martin Luther King, Jr., in Selma, Alabama. A black-andwhite photo of Iakovos is displayed in the museum's Reflection Area, next to a series of photos of other social activists, including Booker T. Washington, Ida B. Wells, Dorothy Height, and Malcolm X (see Figure 2.3). Dracopoulos describes the donation in relationship to this revered figure in the GreekAmerican community (TNH Staff 2015). He was inspired to give to honor Iakovos "who dared under very difficult conditions of that time to 


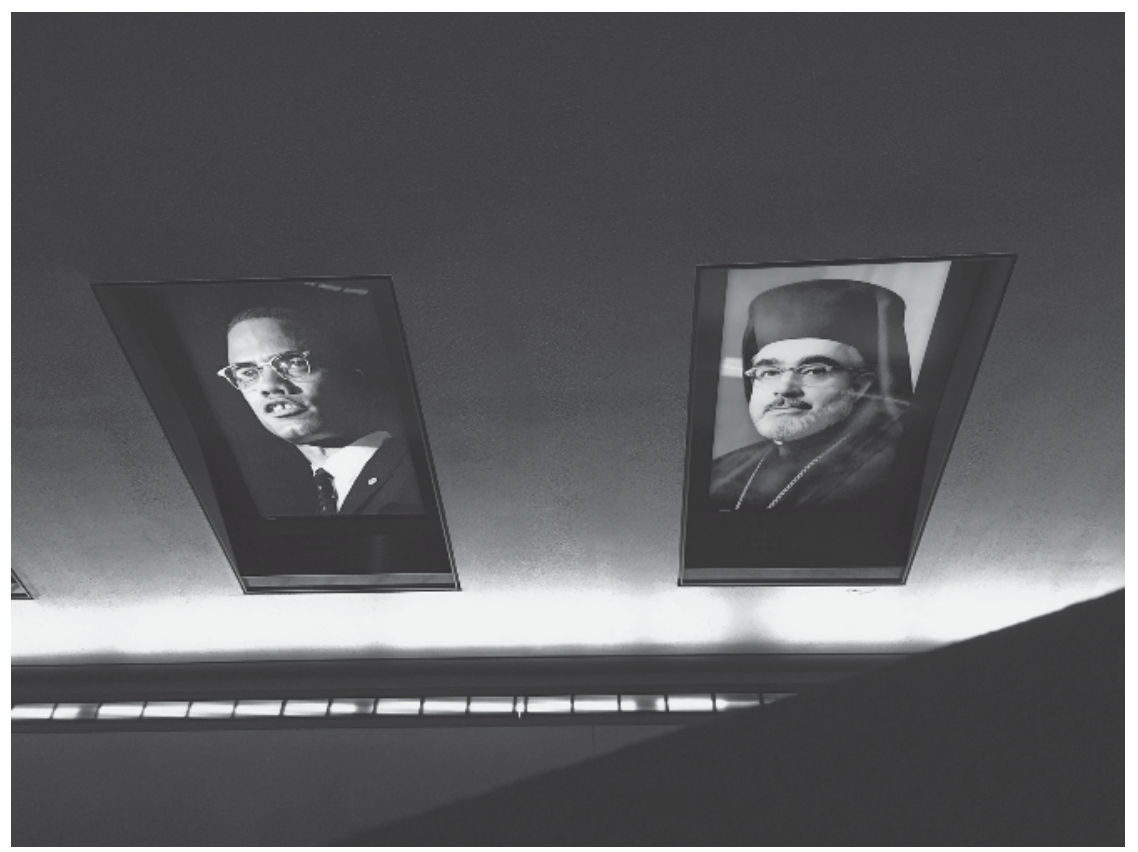

Figure 2.3 Photograph of Malcolm X (left) and Archbishop Iakovos of America (right) at the National Museum of African American History and Culture.

march alongside Dr. Martin Luther King Jr. in the 1965 Selma, AL, civil rights march.” The Greek Orthodox Archdiocese of America also released a statement heralding the donations noting, "These grants were made in honor of Archbishop Iakovos' leadership and legacy in the area of civil and human rights ..." (Greek Orthodox Archdiocese of America 2015).

Intersections between the Greek and African American experiences are emphasized in these comments. Among some Jewish supporters, parallels between the black and Jewish experiences are especially significant aspects of their black museum patronage. In addition to being a longtime trustee at his local African American museum, Bernard also supports Jewish cultural organizations. He believes that slavery is the central experience that the black museum he supports should emphasize. "I think it's absolutely a vital part of the story," he says. His view that slavery should be at the center of the museum's narrative is framed in reference to the Holocaust.

I have to go back for a minute and talk about Judaism, and the Jewish experience, which is different than the African American experience, but there are some similarities. You know about the Holocaust. There was great resistance to creating a Holocaust museum. Why? Because people 
were ashamed of it. They were embarrassed by it. They felt we hadn't done enough. The people there weren't smart enough. They were led like sheep to the slaughter. We here had a level of guilt in those days. Our voices were very muffled. We spoke quietly because in those days, this was before your time, there was a great deal of anti-Semitism that was out in the open, and we weren't in the big banks, insurance companies, law firms, hospitals, universities. There were strict quotas. So that's the era that I was born into and grew up, and now we have this wonderful new world where Jews at least are almost on an equal footing and are so much on an equal footing that we are starting to disappear by inner marrying, which is another whole-we won't get in to that.

Bernard goes on to describe his vision for his local black museum. It is a vision where slavery is placed at the center of the historical narrative. "I tell you, I have not gotten a real reception with the people [at the museum] over the years and I've said this to them also. But so far, nobody has glommed on to it."

I think just like with Jews when the idea of the Holocaust museum came up, “That's ugly, let's bury it, that's ancient history. Let's strive to forget about it." But you know, we don't want to forget about it. It's what has impacted this country in a negative way. It's impacted the black community. It's impacted the white community. It needs to be exposed and then tried to deal with it at a societal level. Society needs to deal with it.

In Bernard's eyes, Jewish Americans and African Americans both have a defining historical experience of collective trauma that has been difficult to publicly memorialize in some contexts. In her research on memory, the sociologist Arlene Stein explains the rise of Holocaust consciousness. How is it that memorials of the Holocaust were largely hidden from broad public view prior to the 1980s, but by then "the destruction of European Jewry, the subject of numerous documentaries and Hollywood films, was widely recognized as a moral touchstone"? she asks (Stein 2014, 3). While the assertion that there were no Holocaust memorials until this period is a myth, she describes how anti-Semitism and a collective American reluctance to turn an eye towards suffering kept widespread acknowledgement of the Holocaust at bay. Stein argues that the memorialization of the Holocaust at large emerged within a broader cultural and political context in which public consciousness surrounding the marginalization of other groups, for example around African Americans and slavery, coalesced (Stein 2014, 5).

In an interview about his family foundation's $\$ 2$ million gift to the NMAAHC, Peter Kovler references the United States Holocaust Museum, to which his foundation also gave a seven-figure donation (Thompson 2016). Kovler's gift was earmarked for an exhibit on Emmett Till, a teenager who was murdered in 1955 after being accused of whistling at a white woman. The exhibition includes the 14-year-old boy's casket. He comments that 
The Holocaust museum is about mortality, lethality and human ugliness but this casket really speaks to that. ... The Smithsonian and the mall can be about the glory of things but it can also be about the worst of human behavior as is illustrated in parts of this museum.

Some Jewish supporters also explicitly reference not only the Holocaust but also the broader experience of Jewish marginalization in describing the value of black museums. One patron describes his commitment to racial equality in relationship to his family's long commitment to dissolve racial boundaries:

I come from an East European Jewish family. My grandparents came at a young age from Russia, from Poland. ... [T] hese Jewish refugees who came from Poland and Russia, they saw that the treatment of blacks in this country was worse than the treatment of Jews over there. "How could that be?" So it's in the DNA of my family I guess and part of the Jewish mission. Like [Elie] Wiesel who just died said, "The mission of the Jew is to make the world more human, not to make it more Jewish." So my family has always been keyed into that. We've always been taught that there are two types of people in the world, not just black, white or Jew, gentile, or man, woman, but decent and indecent, and to strive to be decent. So when you see indecency you're supposed to stand up, not just stand by it, and that's really what I try to do every day.

For these patrons, the black past is one where the intersections with white and white ethnic experiences are particularly salient. They relate to the African American experience by drawing parallels with white and white ethnic experiences and making visible points of interchange between the groups. But it is not only that the interracial dynamics of black pasts are especially salient to some white supporters, but also that the importance of these narratives for recasting white attitudes are particularly highlighted.

John, who brings white friends and colleagues to the black museum that he supports, emphasizes how the visits have the potential to make whites more racially tolerant. After visiting, he says, his guests "tell me they have a shift in perception."

They tell me they do, and I think it's usually true. I'll give you an example. I brought one couple in here twice ... and about a year ago they invited me down to Café BBT [a nearby bar and club] in the afternoon because there was a musician that they thought I should see. So, that was them inviting me back into the community. I guess I should say that I have had some success. I had never really thought about that until right now. There was some kind of a little bit of a circle.... I don't think you can overstate the importance of it particularly in our time right now. It seems to me that everybody's pulling back into their tribes and 
feeling intolerant. Maybe it's the media, but I feel like there's a growing intolerance in this country among the different tribes, and so I think it's hugely important that we get back to becoming one community. I don't like what I see going on right now. I'd like to think that when you come here, if you have a prejudice against African Americans, I'd like to think that when an African American extends his hand and greets you and welcomes you when you walk into the museum-and they do-that you feel, “Wait a minute. This isn't what I thought I was going to see here. I thought I was going to see antagonism. I thought I was going to see a backlash, 'Like, what's this white guy doing here?"' and there's none of that. I think that that can begin to build bridges. Maybe I'm naïve, maybe I'm living in a dream world, but I have to believe that it has some impact. A minor wind, but maybe it grows.

While John emphasizes the potential of the black museum that he supports to open the hearts and minds of whites in his circle, Anne, a white trustee at a black museum in a different city, describes how she has personally become more informed about race as a result of her interactions on the board. "It's like anything, the more you learn, the more you learn," she says about her experience as a trustee.

It's interesting, I suppose, as a white person. As a woman coming up in the corporate world, I was usually the only woman, but at least they were all white. At our museum, I'm usually one of the only. There were maybe two or three white people on the board. So, I'm a minority in those settings, and it's really kind of interesting to feel. But I don't feel isolated. I suppose that's just a typical white person who's dominated everything. I think ... that there is a world here that we think we understand as white people that we don't really. ... But I think you probably talk more about race relations with people of different races than you do all in one. So, I think it has helped that. ... I do think that organizations that can help people see a fuller picture are all for the good. It's very, very, very important. I think as a white person, I need to help do what I can, and I just think that's an important thing. I really do. So, that's why I'm doing it [serving on the museum board].... I don't mean to be Pollyannaish, but it's just obvious. Whenever you limit yourself, you really limit yourself. ... I have tried very hard because I'm white, I'm really white, to listen and to really try to say, "I'm wanting to go more than 50 percent of the way," and that's the way I conduct myself.... That is something that I can do in my little corner to bring better relations and just to have fun. I don't know, we had fun at this dinner party the other night [a dinner for the museum where she and her husband were in the racial minority]. I started, I don't even know how we got into it, astrological stuff. We just had fun as people. So, I have all these endless conversations. But, at least I think it's important to be aware of racial 
divides and racial tensions in the effort to end them and I do believe that eventually it will.

In an editorial for the Washington Post on the NMAAHC, the columnist Petula Dvorak, who is white, also articulated the view that a primary function of African American museums is to teach tolerance to whites. It begins, "My fellow white people: Listen up, please" (Dvorak 2016). She goes on to encourage whites to visit the museum even if it might induce feelings of shame:

Some of what you see might make you feel ashamed at parts of our past. But now you know. And in knowing, that shame will give way to the deep respect and pride that we should have in all our fellow Americans.

Dvorak's comments are reminiscent of some white patrons' heightened sensitivity to the role that black museums can play in decreasing white prejudice and discrimination and also their awareness that some "fellow white people" are reluctant to confront the nation's racist past. Chris, a white trustee who has had difficulty soliciting donations from his wealthy white clients, says,

I think that many within the white community here, those who took the time to come here, left here seeing this as a slavery museum. The thinking was, “Okay, I get it. I've seen how bad this is. I've seen it once. I don't need to go see it again. ... The perception is that the message that's communicated here is that slavery is bad and that you caused it. I don't agree that that's what's being said here, but that's the interpretation."

Chris's comments speak to how some white visitors to black museums get the sense that even if their families were not directly involved in slavery that they are viewed as guilty by association by virtue of their race. As one white supporter shared, some of his extended family members have little interest in visiting a local African American museum because of their belief that their ancestors who immigrated to the United States after Emancipation "had nothing to do with slavery" and that "they shouldn't be blamed for racism." In his view, this sentiment leads to an irony that "whites who may learn the most from a visit are the least likely to come."

White supporters are often particularly attuned to the interracial dimensions of the black past and the potential for white transformation through engagement with black museums. This emerges from their especially intimate familiarity with white and white ethnic realities and lived experiences as whites and white ethnics. The racial and ethnic value of black museums cannot only be articulated within interracial and black frames but also within a frame that emphasizes the African diaspora. Next, I describe how first- and second-generation supporters from Africa and the Caribbean 
place particular emphasis on the value of African American museums for these groups.

\section{The African diaspora}

Most blacks in the United States are descendants of enslaved Africans who were brought to the Americas during the transatlantic slave trade. However, in the last several decades, the black population in the United States has become more ethnically diverse. Shifts in immigration law, along with other global political and economic changes, have increased immigration from Africa and the West Indies (Imoagene 2017; Thomas 2014, 1-18). ${ }^{16}$ Across the nation, immigrants constitute only around 10 percent of the black population (Imoagene 2017, 5). However, in some areas, such as New York and Massachusetts, they constitute over a quarter (Smith 2014, 10). Moreover, 18 percent of blacks are now either immigrants or the children of immigrants (Anderson and López 2018). On the one hand, immigrants of African descent are often racialized as black, so their experiences and identity overlap with native-born blacks in some ways. On the other hand, even into the second generation their ethnic identities and cultural practices often remain salient, along with structural ties to ethnic community members and institutions (Dávila 2008, 2012; DiMaggio and Fernández-Kelly 2010; Imoagene 2017; Pierre 2004, 2010; Vickerman 1999; Waters 1999).

In the context of philanthropy and black museums, this orientation towards communities of origin is articulated in first- and second-generation supporters' emphasis on the interconnectedness of black museums with broader African Diasporic communities. One way that this manifests itself is that these supporters' philanthropic commitment to African American museums is often coupled with a commitment to giving to issues and organizations that specifically address ethnic communities. For example, one first-generation supporter from the West Indies describes how after moving to the United States she started to take on an African American identity. "Coming to America, I think I'm identifying more with African Americans. Most of my new friends are African Americans," she says. Yet, she continues to have a strong West Indian identity. Her sense of connection to both communities is articulated through giving through her family foundation. "We [focus on] kids with African American and West Indian heritage," she says. This donor and other first- and second-generation supporters from Africa and the West Indies often emphasize how their giving to African American museums is intertwined with philanthropic commitments to their ethnic communities.

Sarah is also from the West Indies, though she is second generation. She is a trustee at her local African American museum and on the board of an ethnic-focused professional organization that is directed at nurturing relationships within, and empowering, the ethnic community. Sarah works 
in the culture industry and describes how she organized an event at the museum for the ethnic professionals group. "I was on a lot of boards, so it's connecting those dots," she explains.

I was the president of one of the organizations, the Caribbean Professionals, and we wanted to do a fundraiser. "Why not do it in the museum," I said. So, my board connection is, "Oh, I'm on a board. I can rent out the museum and make money for the museum." While making money for the museum, I'm also giving my audience a nice look in terms of arts and culture.

At the event, which was focused on a celebration of the West Indian nation where Sarah was born, event-goers were served ethnic cuisine and given a tour of the museum. This event took on significance for Sarah not only as a potential business booster but also because of its relationship to the Caribbean and African American communities to which she is committed. It helped to nurture the space of philanthropy at the museum as a specifically West Indian space for the evening of the event.

It is not only a heightened concern with coupling African American museum philanthropy with philanthropy in ethnic communities that distinguishes some immigrant supporters, but also a particular concern with the museums being a part of diasporic neighborhoods. As the population of immigrants from Africa and the West Indies grows, the spatial landscapes of communities in the United States are also changing. The historically black neighborhoods where some African American museums are located have experienced an increase in African and West Indian immigrants. One secondgeneration patron with relatives who live in the community where the black museum she supports is located describes the immigrant world of her family. "It's all immigrants—friends, church, stores, everything," she explains. While the African American museum is part of the physical matrix of their community, her relatives are not directly involved with it. "Sometimes I question if we [the museum] do enough to reach out them," she says. "The African American focus is fine but there is room for branching out more. Just in terms of something as simple as labels-they're all in English. I have some relatives who aren't [fluent in] English," she says. In the streets surrounding some African American museums, the sounds of people speaking in accented English and other languages, such as Spanish, are part of the broader cacophony of voices. These voices testify to the ethnic diversity in the communities of some African American museums. In the mind of this supporter, her museum will not be fully integrated into its changing neighborhood until it begins to place more emphasis on the culture of its ethnically diverse neighbors. In particular, she highlights the lack of bilingual texts as a barrier for engagement.

First- and second-generation supporters also often display a particular interest in narratives in black museums that center broader African 
Diasporic communities. While there is often a centering of the African American experience within African American museums, many also feature exhibitions that highlight the broader diasporic experience. For example, museums with sections on slavery often begin the story of the transatlantic slave trade in Africa. It is also not unusual for contemporary art exhibitions to include artists from across the African diaspora. Some museums also display traditional African art, and still others have mounted exhibitions that focus on black immigrant groups in the United States. Bikila, who is an African immigrant, praises the museum where he is on the board precisely because it addresses the distinctiveness of the recent immigrant experience in its exhibitions. Along with serving on the museum board, he is active in his local ethnic community and in international philanthropy directed at his country of birth. He praises the museum for telling a story of global black migration that begins with the Middle Passage and continues into the 21st century. "In the last 25 to 30 years ... several immigrants from Africa have come and made this area their home," he says.

Now, there are over 50,000 people that are in this area, whereas 20 years ago there was probably 20 or 30 . So, that's a big change in terms of the culture and the historical perspective.... They [the African immigrants] came either of their own will or they came running away from oppressive governments. As such, when they come here, the cultural connection is still there because they have families there. But, at the same time, now they have children in this country. How are you going to pass on that cultural connection to your children and also inform others around you in your new community? ... So, at the museum we had an exhibition [on the immigrants] which I think is really great because it taught two things. It taught the immigrants. We appreciate what the forefathers have done because they came here and they sweat[ed] blood, faced oppression and because of their movement, because of their struggling to really get us to where we are now, we are benefiting as productive members of the society. Within that, you've got the Americans who were born in this country, and the immigrant children who were also born in this country, coming from two different sides of the story. So, the way you can really create a bonding between these two, and learn and share, would be by preserving all the culture and the history - the arts, music and culture ... to really open up a better dialogue.

For Bikila, this exhibition has significance as a didactic and honorific tool that can be used within the immigrant community to nurture memories about the past and reverence for forebears. However, he also places value on the role that it can play in reciprocal education, or helping the immigrant and native black communities learn more about one another. In the eyes of, Rosa, a second-generation Afro-Latinx from the West Indies, even the African American focus of the museum that she supports speaks to 
the immigrant experience. Both of her parents were born in the Caribbean, and though her mother "was on the opposite side of the spectrum," her father has a strong black identity. "I grew up with my dad teaching me so much black stuff," she says. "My dad taught me the words to the African American anthem. He took me to see black movies. He introduced me to black culture and black music. He identified as a black man." While the 19th-century African American historical narratives that are featured at the museum she supports do not generally highlight the specific ancestral pasts of recent immigrant families like her own, she sees them as identifiable via their broader arc of encountering and overcoming inequity. "The museum can be a space that represents home and represents self-determination for so many of us," she says.

I think about the immigrant experience and how much war has been fought, and is still being fought, to create space, and have space for ourselves and for our families, and for our futures. The museum represents a community [African American] that has that ability, and that has done that, despite all of the challenges that were presented at that specific point in history [the 19th century].... I just feel like there is a framing that can be done to invite several different types of communities to that space that is housed on shared grounds.... There is a need to make this relevant to everyone because it is. There is a very proactive approach that we have to take to inviting communities that we weren't traditionally engaging with because we didn't see them as being part of this conversation.

In her view the African American story of overcoming challenges is one that is shared with immigrant communities. While she thinks that more outreach is needed to help her museum better connect with its increasingly first- and second-generation neighbors, she does not think that the basic mission of the museum is inherently at odds with their experiences. She believes that by highlighting how the immigrant community faces different versions of the African American experience, the museum can help to draw in this audience.

These first- and second-generation supporters from Africa and the West Indies are especially sensitive to African American museums as situated within the broader African diaspora. Their philanthropic priorities are often particularly attuned to their communities of origin, such that giving to African American museums is balanced with these other interests. As members of multiple communities, they often feel a commitment to philanthropic leadership across these spaces. Moreover, lived experiences and close ties to others with lived experiences as immigrants often attune first- and second-generation supporters to how various aspects of black museumssuch as the narratives featured in them or the languages used in them-do or do not connect with broader African diasporic communities. 


\section{Conclusion}

This chapter highlights how the value of African American museums is defined by supporters in relationship to race and ethnicity. At the most basic level, supporters see these museums as both African American and all-American institutions. However, awareness of and sensitivity to these different sides of black museums are conditioned by the material and cultural realities of their supporters' lives, which themselves vary by race and ethnicity. This means that while black and white patrons alike typically insist on the racial and ethnic specificity and universality of these institutions, black patrons are often especially attuned to the functions and contributions of these cultural institutions for blacks, and whites are often particularly cognizant of the institutions' role in the lives of whites. Still further, it is first- and secondgeneration African and West Indian supporters who often have a heightened awareness of the position of African American museums as black diasporic institutions. I account for these differences by structural factors, such as the distinct lived experiences of patrons from various racial and ethnic groups, along with cultural factors, such as their various identities.

This chapter builds on the sparse sociological literature on race and ethnicity and museum patronage. Although class is at the center of Ostrower's (2002) study of trustees at majority museums and opera houses, she finds that some black and Latinx board members make sense of their board roles in connection with their racial and ethnic identities. Here, I extend Ostrower's analysis not only by examining the links between race, ethnicity, and patronage at African American museums, but also by examining a more diverse range of identities. I elaborate how consciousness of one's racial and ethnic identity informs how not only minority patrons define what is important about museums, but also white patrons. In this context, whites are often highly conscious about their race and ethnicity, and this awareness is intertwined with how they assess what matters about black museums. Also, while Ostrower's analysis considers that black patrons may approach cultural patronage in ways that vary from their white counterparts, here we see how black patrons' museum values vary from one another based on ethnicity.

As we saw in this chapter, some supporters, such as the black entrepreneur who redirects a portion of his business profits to black organizations in his neighborhood, see a close link between their support of African American museums and their professional lives. In the next chapter, I take an in-depth look at these ties by exploring the world of work and giving to African American museums.

\section{Notes}

1 This bill, H.R. 3442, was introduced by Representative John Lewis of Georgia and focused on the formation of a special commission to put together a course of action to establish the NMAAHC. As noted in the legislation, the commission was directed to create racially specific fundraising plans. 
2 I also discuss whites' greater emphasis on black museums for specific white ethnic groups such as Greeks.

3 In making this argument, I build on the sociologist Peggy Levitt's (2015) research on the cosmopolitan-nationalism continuum at museums. Levitt argues that museums often fall along a spectrum of emphasizing either the collectivity of the nation or the humanity of all people. In her analysis, these are objective differences between museums that are a function of the broader historical and cultural contexts in which they are embedded. Here, I extend Levitt's research by turning the focus to a particular type of museum, the African American museum, and exploring the balance between African American and all-American, as well as the weight of African American and African Diasporic. Moreover, instead of analyzing objective differences between museums themselves in these orientations, I focus on perceptual distinctions among patrons.

4 Research on museum-going also finds that race organizes cultural consumption. For example, in her research on natural history museums, Monique Scott (2008) finds that black visitors are more likely to emphasize Africa as an important site of cultural heritage and to offer more critical interpretations of exhibitions.

5 Highlighting race and ethnicity as poles of difference render internal variations within racial and ethnic groups less visible. These differences do exist, and some, such as gender, are explicitly touched on in this chapter. Others, such as profession, are not formally accented but are manifest in the discussion. While intraracial and intraethnic differences in understanding racial and ethnic value do exist, the focus on intergroup variations highlights patterns of evaluation that are more or less common within particular categories.

6 Black fraternities and sororities are foundational organizations in black middleclass life (Graham 1999, 83-100). These organizations are highly active outside of colleges and universities. Individuals who pledge in college often maintain active membership after they graduate. In addition, it is common for members to join these black fraternities and sororities after graduation.

7 The role of black museums in black middle-class life is also illustrated by the fact that in my sample of more than 2,000 donations of $\$ 25,000$ or more to black museums, all of the gifts from social organizations are from black middle-class social organizations.

8 These are both single-sex professional and social organizations. The former is for men, and the latter for women.

9 Lucy's comments are brought into further context when considering the sociologist Milton Gordon's work on race and class (Banks 2017). In his research on assimilation, Gordon (1964) distinguishes group boundaries based not only on racial and ethnic "vertical stratifications" but also on social class "horizontal stratifications." He describes groups created by these intersecting boundaries as "ethclass" groups. Under Gordon's classification, the middle and upper class are subdivided into specific ethclass groups such as the black upper-middle class and the white upper-middle class. According to Gordon, while the middle and upper class "tend to act alike and have the same values even if they have different ethnic backgrounds" (1964, 52), social participation within the middle and upper class, including primary relationships and organizational affiliations, is concentrated within the ethclass group. Put into Gordon's terms of ethclass groups, Lucy emphasizes that for the black elite, African American museums are a central organization that facilitates ethclass bonds. In contrast, majority museums bring together the white elite. 
10 For twenty years, Joan Weill was a trustee of the Alvin Ailey American Dance Theater, serving as board chair from 2000 to 2014. Over several years she and her husband Sandy donated over \$50 million to the organization, including onetime pledges of $\$ 18.4$ million and $\$ 16$ million. The former gift by the white couple was the single largest donation to the organization to date. In recognition of the gift, the company's new Manhattan building was named the Joan Weill Center for Dance (Catton 2014).

11 In an analysis of more than 2,000 donations of $\$ 25,000$ or more to a small sample of black museums, I found that at most museums it was more common for 60 percent or more donations from individuals (including family foundations) to come from whites than blacks.

12 There are also exceptions to this pattern. For example, there is a black patron at the Goldsville African American Museum who is highly integrated into the city's white elite, even extending to the prep school that she attended as a youth.

13 In educational research, the term "temporary minorities" has been used to refer to white students who attend Historically Black Colleges and Universities (Strayhorn 2010).

14 The couple met while attending a Historically Black College and University (HBCU). Their school is an elite HBCU that is part of the black middle-class organizational network (Graham 1999, 63-82).

15 In November 2015 when historical photographs were projected onto the NMAAHC's facade, one image showed Iakovos standing next to King.

16 The major immigration law contributing to this shift is the Hart-Cellar Immigration Act (1965), which eliminated national quotas favoring Europeans.

\section{References}

Alexander, Keith L. 2016. “'Who Is This Robert Smith?’: A Quiet Billionaire Makes Some Noise with \$20 Million Gift to the African American Museum.” Washington Post, September 24, 2016. Accessed January 10, 2017. www.washingtonpost.com/ national/who-is-this-robert-smith-a-quiet-billionaire-makes-some-noise-with-20million-gift-to-the-african-american-museum/2016/09/23/547da3a8-6fd0-11e68365-b19e428a975e_story.html?utm_term=.07de1b9a4ba4.

Allen, Walter. 1992. "The Color of Success: African-American College Student Outcomes at Predominantly White and Historically Black Public Colleges and Universities." Harvard Educational Review 62(1): 26-45.

Anderson, Monica, and Gustavo López. 2018. "Key Facts About Black Immigrants in the U.S.” Pew Research Center, January 24, 2018. Accessed February 10, 2018. www.pewresearch.org/fact-tank/2018/01/24/key-facts-about-black-immigrantsin-the-u-s/.

Baltzell, E. Digby. 1964. The Protestant Establishment: Aristocracy and Caste in America. New York, NY: Random House.

Banks, Patricia A. 2010. Represent: Art and Identity Among the Black Upper-Middle Class. New York, NY: Routledge.

- 2012. "Cultural Socialization in Black Middle-Class Families." Cultural Sociology 6(1): 61-73.

- 2017. "Ethnicity, Class, and Trusteeship at African American and Mainstream Museums.” Cultural Sociology 11(1): 97-112. 
2018. "Money, Museums, and Memory: Cultural Patronage by Black Voluntary Associations." Ethnic and Racial Studies. https://doi.org/10.1080/ 01419870.2018 .1540789$.

- 2019. "Cultural Justice and Collecting: Challenging the Underrecognition of African American Artists." In Race in the Marketplace: Crossing Critical Boundaries, edited by Guillaume D. Johnson, Sonya A. Grier, Kevin Thomas, and Anthony Kwame Harrison. London: Palgrave.

—. Forthcoming. "High Culture, Black Culture: Strategic Assimilation and Cultural Steering in Museum Patronage.” Journal of Consumer Culture.

Barnes, Riché J. Daniel. 2016. Raising the Race: Black Career Women Redefine Marriage, Motherhood, and Community. New Brunswick, NJ: Rutgers University Press.

Bertagnoli,Lisa.2012. "Nonprofit Boards Slow to Diversify.” Crain's Chicago Business, November 3, 2012. Accessed January 10, 2017. www.chicagobusiness.com/article/20121103/ISSUE01/311039974/why-white-men-still-dominate-nonprofitboards.

Bobo, Lawrence, James R. Kluegel, and Ryan A. Smith. 1997. "Laissez-Faire Racism: The Crystallization of a Kinder, Gentler, Antiblack Ideology.” In Racial Attitudes in the 1990s, edited by Steven A. Tuch and Jack K. Martin, 15-42. Westport, CT: Praeger.

Bonilla-Silva, Eduardo. 2010. Racism Without Racists: Color-Blind Racism and the Persistence of Racial Inequality in the United States. Lanham, MD: Rowman and Littlefield.

Brown, Claudine. 1991. Final Report of the African American Institutional Study. Smithsonian Institution Archives, Accession 07-172. Washington, DC: National Museum of African American History and Culture, Planning Records.

Building Blocks. 2014. "Building Blocks: Black Philanthropy and the National Museum of African American History and Culture." Uptown, February 4, 2014. Accessed January 10, 2017. www.uptownmagazine.com/2014/02/blackphilanthropy-and-the-national-museum-of-african-american-history/2/.

Carson, Emmett Devon. 1993. A Hand Up: Black Philanthropy and Self-Help in America. Washington, DC: Joint Center for Political and Economic Studies Press.

Catton, Pia. 2014. “Joan Weill Brought Ailey to Center Stage.” Wall Street Journal, November 30, 2014.

Collins, Sharon M. 1997. Black Corporate Executives: The Making and Breaking of a Black Middle Class. Philadelphia, PA: Temple University Press.

Conley, Dalton. 1999. Being Black, Living in the Red: Race, Wealth, and Social Policy in America. Berkeley: University of California Press.

Crockett, David. 2017. "Paths to Respectability: Consumption and Stigma Management in the Contemporary Black Middle Class." Journal of Consumer Research 44(3):554-581.

Dávila, Arlene. 2004. Barrio Dreams: Puerto Ricans, Latinos, and the Neoliberal City. Oakland: University of California Press.

- 2008. "From Barrio to Mainstream: On the Politics of Latino/a Art Museums." In Latino Spin: Public Image and the Whitewashing of Race, 119137. New York, NY: NYU Press.

Davis, Marcia. 2016. "An Interview with Oprah Winfrey: 'I Come as One, but I Stand as 10,000.' Washington Post, September 15, 2016. Accessed January 10, 2017. www.washingtonpost.com/lifestyle/magazine/an-interview-with-oprahwinfrey-i-come-as-one-but-i-stand-as-10000/2016/09/14/25f34b94-4a11-11e6bdb9-701687974517_story.html?utm_term=.b9a236a4b506. 
Dawson, Michael C. 1994. Behind the Mule: Race and Class in African-American Politics. Princeton, NJ: Princeton University Press.

DiMaggio, Paul, and Patricia Fernández-Kelly. 2010. Art in the Lives of Immigrant Communities in the United States. Rutgers Series: The Public Life of the Arts, edited by Paul DiMaggio and Patricia Fernández-Kelly. New Brunswick, NJ: Rutgers University Press.

DiMaggio, Paul, and Francie Ostrower. 1990. "Participation in the Arts by Black and White Americans.” Social Forces 68(3): 753-778.

DuBois, W.E.B. 1996 (1903). “The Talented Tenth.” In The Future of the Race, edited by Henry Louis Gates and Cornel West, 133-157. New York, NY: Knopf.

Dvorak, Petula. 2016. "Why White People Need to See the Searing New African American Museum Right Now.” Washington Post, September 22, 2016. Accessed January 10, 2017. www.washingtonpost.com/local/why-white-people-need-tosee-the-searing-new-african-american-museum-right-now/2016/09/22/f76fc65c80d0-11e6-8327-f141a7beb626_story.html?utm_term=.0de94b9a4e79.

Edsall, Thomas B. 2017. "Black People Are Not All 'Living in Hell." New York Times, April 27, 2017. Accessed May 10, 2018. www.nytimes.com/2017/04/27/ opinion/black-people-are-not-all-living-in-hell.html.

Feagin, Joe R. 1991. "The Continuing Significance of Race: Antiblack Discrimination in Public Places.” American Sociological Review 56(1): 101-116.

Feagin, Joe R., and Melvin P. Sikes. 1994. Living with Racism: The Black MiddleClass Experience. Boston, MA: Beacon Press.

Fleming, Crystal M., and Lorraine E. Roses. 2007. "Black Cultural Capitalists: AfricanAmerican Elites and the Organization of the Arts in Early Twentieth Century Boston." Poetics 35(6): 368-387.

Frazier, Edward Franklin. 1997[1957]. Black Bourgeoisie. New York, NY: Free Press. “Game Changer: Gifts Are Changing Our Very Footprint, Michael Jordan.” 2016. Impact: Smithsonian Campaign Newsletter, September11, 2016.

Gordon, Milton M. 1964. Assimilation in American Life: The Role of Race, Religion and National Origins. New York, NY: Oxford University Press.

Graham, Lawrence Otis. 1999. Our Kind of People: Inside America's Black Upper Class. New York, NY: HarperCollins.

Grams, Diane. 2010. "Distinction of the Black Middle Class." In Producing Local Color: Art Networks in Ethnic Chicago, edited by Diane Grams, 81-87. Chicago, IL: University of Chicago Press.

Grazian, David. 2005. Blue Chicago: The Search for Authenticity in Urban Blues Clubs. Chicago, IL: University of Chicago Press.

Greek Orthodox Archdiocese of America. 2015. "Stavros Niarchos Foundation Honors Late Archbishop Iakovos' Pioneering Contribution to Civil Rights.” Greek Orthodox Archdiocese of America, December 17, 2015. Accessed January 10, 2017. www.goarch.org/-/stavros-niarchos-foundation-honors-late-archbishopiakovos-pioneering-contribution-to-civil-rights.

Halle, David. 1993. Inside Culture: Art and Class in the American Home. Chicago, IL: University of Chicago Press.

Harvey Wingfield, Adia. 2011. Changing Times for Black Professionals. New York, NY: Routledge.

Hochschild, Jennifer L. 1995. Facing Up to the American Dream: Race, Class, and the Soul of the Nation. Princeton, NJ: Princeton University Press. 
H.R. 3442. 2001. National Museum of African American History and Culture Plan for Action Presidential Commission Act of 2001, Public Law Public Law 107106, 107th Congress (2001): 1009-1011.

H.R. 3491. 2003. National Museum of African American History and Culture Act, Public Law 108-184, 108th Congress (2003): 1-8.

Imoagene, Onoso. 2017. Beyond Expectations: Second-Generation Nigerians in the United States and Britain. Berkeley: University of California Press.

Knich, Diane. 2014. "Dig Finds Remnants of Slavery Wharf Site of Future AfricanAmerican Museum was Entry Point for Over 100,000." The Post and Courier, November 29, 2014. Accessed January 10, 2017. www.postandcourier.com/ archives/dig-finds-remnants-of-slavery-wharf-site-of-future-african/article_ 8c910069-b5fa-5615-9755-265a64bbb57e.html.

Lacy, Karyn R. 2004. "Black Spaces, Black Places: Strategic Assimilation and Identity Construction in Middle-Class Suburbia." Ethnic and Racial Studies 27(6): 908-930.

- 2007. Blue-Chip Black: Race, Class, and Status in the New Black Middle Class. Berkeley: University of California Press.

Landry, Bart. 1987. The New Black Middle Class. Berkeley: University of California Press.

Landry, Bart, and Kris Marsh. 2011. "The Evolution of the New Black Middle Class." Annual Review of Sociology 37: 373-394.

Levitt, Peggy. 2015. Artifacts and Allegiances: How Museums Put the Nation and the World on Display. Oakland: University of California Press.

Lloyd, Richard. 2010. Neo-Bohemia: Art and Commerce in the Postindustrial City. 2nd ed. New York, NY: Routledge.

"Michael B Moore-Charleston International African American Museum.” 2016. YouTube video, 8:21 min. Posted by bounce charleston, June 28, 2016. www. youtube.com/watch? $\mathrm{v}=\mathrm{XObNvPN} 27 \mathrm{Xg}$.

Molnár, Virág, and Michèle Lamont. 2002. "Social Categorisation and Group Identification: How African-Americans Shape Their Collective Identity Through Consumption." In Innovation by Demand: An Interdisciplinary Approach to the Study of Demand and Its Role in Innovation, edited by Andrew McMeekin, Mark Tomlinson, Ken Green, and Vivien Walsh, 88-111. Manchester, UK: Manchester University Press.

Moore Charitable Foundation. 2016. "The Moore Charitable Foundation Pledges \$1.5 Million to the National Museum of African American History and Culture." Moore Charitable Foundation, September 23, 2016. Accessed January 10, 2017. http://moorecharitable.org/9-23-2016-the-moore-charitable-foundationpledges-1-5-million-to-the-national-museum-of-african-american-history-andculture/.

National Museum of African American History and Culture Plan for Action Presidential Commission. 2003. The Time Has Come: Report to the President and to the Congress. Smithsonian Institution Archives, Accession 07-172. Washington, DC: National Museum of African American History and Culture, Planning Records. Oliver, Melvin L., and Thomas M. Shapiro. 1997. Black Wealth/White Wealth: A New Perspective on Racial Inequality. New York, NY: Routledge.

Ostrower, Francie. 2002. Trustees of Culture: Power, Wealth, and Status on Elite Arts Boards. Chicago, IL: University of Chicago Press. 
Parkinson, Alexander. 2016. Better Together: Why a United Front Can Propel Diversity and Inclusion and Corporate Philanthropy in the United States. New York, NY: The Conference Board.

Pattillo, Mary E. 2007. Black on the Block: The Politics of Race and Class in the City. Chicago, IL: University of Chicago Press.

Pattillo-McCoy, Mary. 1999. "Middle Class, Yet Black: A Review Essay.” African American Research Perspectives 5: 25-38.

Pierre, Jemima. 2004. "Black Immigrants in the U.S. and the 'Cultural Narratives' of Ethnicity." Identities: Global Studies in Culture and Power 11(2): 141-170.

- 2010. "Racial Americanization: Conceptualizing African Immigrants in the U.S." Letters: The Semi-Annual Newsletter of the Robert Penn Warren Center for the Humanities Vanderbilt University 18(2): 1-4.

Ruffins, Fath Davis. 1998. "Culture Wars Won and Lost, Part II: The National African-American Museum Project.” Radical History Review 1998(70): 78-101.

Scott, Monique. 2008. Rethinking Evolution in the Museum: Envisioning African Origins. London, UK: Routledge.

Shapiro, Thomas M. 2005. The Hidden Cost of Being African American: How Wealth Perpetuates Inequality. New York, NY: Oxford University Press.

Smith, Candis Watts. 2014. Black Mosaic: The Politics of Black Pan-Ethnic Diversity. New York, NY: New York University Press.

Smithsonian Campaign. n.d. "Family's Gifts Tell Story of Four Generations." Smithsonian Museum. Accessed September 9, 2017. https://smithsoniancampaign. org/unit/national-museum-african-american-history-and-culture\#story-3.

Stein, Arlene. 2014. Reluctant Witnesses: Survivors, Their Children, and the Rise of the Holocaust Consciousness. Oxford, UK: Oxford University Press.

Strayhorn, Terrell L. 2010. Majority as Temporary Minority: Examining the Influence of Faculty-Student Relationships on Satisfaction Among White Undergraduates at Historically Black Colleges and Universities. Journal of College Student Development 51(5): 509-524.

Taft, J. Richard, and Alice Green Burnette. 2003. Final Report: Planning and Organization for a Private Sector Fundraising Campaign in Behalf of the National Museum of African American History and Culture. Smithsonian Institution Archives, Accession 07-172. Washington, DC: National Museum of African American History and Culture, Planning Records.

Tatum, Beverly Daniel. 1987. Assimilation Blues: Black Families in a White Community. Contributions in Afro-American and African Studies, Vol. 108. New York, NY: Greenwood Press.

Thomas, Kevin J. A. 2014. "Race, Ethnicity, and African Immigration to the United States." In Diverse Pathways: Race and the Incorporation of Black, White, and Arab-Origin Africans in the United States, edited by Kevin J. A. Thomas, 1-18. East Lansing: Michigan State University Press.

Thompson, Krissah. 2016. "'How Can You Fail to See the Links Between Current Events ... and the Brutal Death of Emmett Till All Those Years Ago?'” Washington Post, September 24, 2016. Accessed January 10, 2017. www.washingtonpost. com/lifestyle/2016/live-updates/arts-entertainment-news/the-african-americanmuseum-opens/how-can-you-fail-to-see-the-links-between-current-events-andthe-brutal-death-of-emmett-till-all-those-years-ago/?utm_term $=.874 \mathrm{~b} 050 \mathrm{e} 8 \mathrm{~d} 9 \mathrm{f}$.

TNH Staff. 2015. "Archdiocese Spotlight Stavros Niarchos Foundation's Iakovos Donation.” National Herald, December 24, 2015. January 10, 2017. www. thenationalherald.com/109527/archdiocese-spotlights-snf-donation-iakovos-honor/. 
U.S. Census Bureau. 2012. "Selected Characteristics of Racial Groups and Hispanic or Latino Population: 2009," Table 36. 2012. In Statistical Abstract of the United States: 2012, 40-41. Washington, DC: Government Printing Office.

Vickerman, Milton. 1999. Crosscurrents: West Indian Immigrants and Race. New York, NY: Oxford University Press.

Waite, Cally L. 2001. "DuBois and the Invisible Talented Tenth." In Feminist Engagements: Reading, Resisting, and Revisioning Male Theorists in Education and Cultural Studies, edited by Kathleen Weiler, 33-46. New York, NY: Routledge.

Waters, Mary C. 1999. Black Identities: West Indian Immigrant Dreams and American Realities. Cambridge, MA: Harvard University Press.

Watkins, Celeste. 2005. "Tale of Two Classes: Socio-Economic Inequality Among African Americans Under 35." In Race and Ethnicity in U.S. Society: The Changing Landscape, edited by Elizabeth Higginbotham and Margaret L. Anderson, 260267. Belmont, CA: Thomson Wadsworth Press.

Wherry, Frederick F. 2008. Global Markets and Local Crafts: Thailand and Costa Rica Compared. Baltimore, MD: Johns Hopkins University Press.

Willie, Charles Vert. 1979. The Caste and Class Controversy. Dix Hills, NY: General Hall.

Willie, Sarah Susannah. 2003. Acting Black: College, Identity, and the Performance of Race. New York, NY: Routledge.

Wilson, William Julius. 1980. The Declining Significance of Race: Blacks and Changing American Institutions. Chicago, IL: University of Chicago Press.

Wingfield, Adia Harvey. 2013. No More Invisible Man: Race and Gender in Men's Work. Philadelphia, PA: Temple University Press.

Zukin, Sharon. 2014. Loft Living: Culture and Capital in Urban Change. New Brunswick, NJ: Rutgers University Press.

Zweigenhaft, L., and Domhoff, GW. 2011. The New CEOs: Women, African American, Latino and Asian American Leaders of Fortune 500 Companies. Lanham, MD: Rowman and Littlefield. 


\section{Doing well by doing good}

\section{Introduction}

June 12, 2016, is marked on the Wilson family's calendar. That evening Phil Wilson, an executive at Simpson, Inc., and Elaine Wilson, a professor in the sciences at Johnson College, will attend the annual fundraiser for the Green Valley African American Museum. Although they will attend the same gala, Elaine and Phil describe the fundraiser in different terms. In Phil's words, the evening will be a "work" event, while Elaine summarizes it as a "social" function. Indeed, it will be a work event of sorts for Phil. Simpson, Inc., is a sponsor of the gala, and Phil will be among a large group of executives from the firm who are in attendance. "We are representing [Simpson]," Phil explains. As a sponsor, Simpson received several tickets to the gala, and they were distributed to managers like Phil. While Elaine may "run into a few people from work" at the fundraiser, they will not be attending through any affiliation with her employer. Her employer is not a sponsor this year, and as far as Elaine knows has never been a sponsor of the annual event.

Phil and Elaine are typical of other black museum patrons who place varying emphasis on the importance of black museums in their work lives. This chapter builds on this theme by elaborating how supporters who work in the private sector, especially managers, lawyers, and entrepreneurs, place more emphasis on the professional value of giving to African American museums than those who work in government and nonprofits. ${ }^{1,2}$ Patrons who work in the private sector tend to place more emphasis on giving as a practice that professionally supports "doing well" and "doing good." On the one hand, members of this group often place significant weight on the ethical components of giving. Giving is an articulation of corporate social responsibility in which business resources, such as money, and skills and knowledge in areas like marketing and management are leveraged on behalf of the nonprofit sector. At the same time, these patrons also appreciate philanthropy at black museums as a practice that can strengthen the position of business. For example, relationships with coworkers and clients are nurtured. In contrast, non-private-sector supporters are less likely to emphasize direct and salient links between their work lives and their engagement with black museums. 
I suggest that the heightened emphasis on profession among patrons who work in the private sector is enabled by distinct structural and cultural features of the contexts in which they work. The high level of embeddedness of businesses in the space of museum philanthropy means that patronage is important for maintaining work ties and identity. The ideologies of corporate social responsibility and enlightened self-interest in the business sector, as well as the strong overlap between the skills and knowledge that museums need and business professionals have, likely further strengthen the emphasis that patrons who work in the for-profit sector place on black museum patronage as a practice that is good for society and good for their careers.

Exploring professional variations in how patrons of black museums define the work value of black museums has important practical and theoretical implications. Increasing the representation of corporate executives on the boards of African American museums has been used as a strategy to augment institutions' access to money and other resources (Datcher 2015; Dingle 2012). However, there is, to my knowledge, no systematic scholarly exploration of the specific perspectives that supporters who work in the private sector bring to black museums. This chapter also advances the scholarship on museum patronage and class. Theory on museum patronage emphasizes how the upper-middle and upper class value museum engagement because of its role in solidifying their class position. By analyzing museum patronage through the lens of profession, this chapter offers deeper insight into how the class-reinforcing effects of museum patronage are variously valued among different types of upper-middle- and upper-class workers. In the next section, I further outline the underlying mechanisms that may contribute to the salience of professional value among supporters who work in business.

\section{Business and culture}

Across a range of contexts, sociological research on valuation and evaluation finds heterogeneity in how professionals from various fields assess worth (Lamont 1992, 2009). These differences are accounted for by the distinct structural and cultural features of those professions. Engaging this research, I propose that the high level of structural embeddedness of corporations in the philanthropic space of museums and other nonprofits, the skills and knowledge overlap in these sectors, along with the ideologies of enlightened self-interest and corporate social responsibility, all contribute to a higher emphasis on the professional value of giving to black museums among patrons who work in businesses.

There has long been an intimate relationship between business and cultural institutions. In the 19th century, it was often titans of industry and their family members who founded major museums and other cultural organizations across the United States. Individual capitalists directed 
business profits to build an institutional base for high culture in cities such as Boston and New York (DiMaggio 1982a, 1982b). The business-cultural institution tie became especially strong in the 1960s. In this period, the philanthropic base of museums shifted from being centered on individuals who made or inherited their fortunes via business to a more diverse mix of supporters, including institutional funders such as corporations (Alexander 1996a, 1996b; Martorella 1990, 1996). Individual firms begin to fund cultural organizations at an unprecedented level, for example through supporting special exhibitions, while the business community initiated more efforts to collectively support the arts. In 1967 Nelson Rockefeller, scion of the Rockefeller family, helped to found the Business Committee for the Arts (BCA) ("Business Group" 1968; "Business Committee" 2018). This organization, which is still in place today, brings together leaders in the business community to encourage corporate support of the arts. Not only have institutional alliances between firms and cultural organizations become more common since the 1960s, but corporations have also increasingly formed their own art collections (Martorella 1990).

The relationships between firms and cultural organizations are part of the broader business/nonprofit philanthropic nexus where the profits of business are transferred to nonprofits and business executives serve on the boards of nonprofits. These relationships are supported not only through industry-wide initiatives such as the BCA, but also by the numerous corporate arts sponsorship programs that are centered at cultural institutions themselves. At majority museums this includes programs like the Corporate Patron Program at the Metropolitan Museum of Art, which was established in 1976, and the Corporate Membership program at MoMA. At black museums it includes programs such as the Corporate Partnership Program at the National Underground Railroad Freedom Center and the Corporate Sponsorship program at the Charles $\mathrm{H}$. Wright Museum of African American History.

This high level of structural embeddedness may enable corporate patrons' stronger emphasis on work value in a few ways. First, the high concentration of corporate workers in the philanthropic sphere of museums and other nonprofits means that giving is an important part of work identity. ${ }^{3}$ It also means that managers are embedded in networks where norms of reciprocity around giving to museums and other nonprofits are important for maintaining relationships. The high presence of corporate professionals in the philanthropic space of museums also means that there are numerous opportunities for them to establish and maintain strategic relationships with one another there.

There is also a distinct set of cultural repertoires within the business sector that may encourage a higher emphasis on work value among corporate professionals. Within individual firms and the field of business at large, the view that giving to nonprofits, including cultural nonprofits, is a responsibility is highly institutionalized. This perspective is captured in the ideology of corporate social responsibility (Barman 2016; Galaskiewicz 1985, 1997). It is a way of thinking that is structured into firms and the business field with 
special initiatives that organize giving. For example, at the professional level, I already discussed the BSC. At the organizational level, some firms, especially those that are large, produce special corporate social responsibility reports and support nonprofits through company-sponsored foundations and direct giving programs. Yet, just as the ethic of corporate social responsibility is salient, so is the related ideology of enlightened self-interest. This ideology holds that while philanthropy is good for society, it is also good for business in the long term (Galaskiewicz 1989; Stendardi 1992, 21-30). This ethic dictates that business support of cultural and other nonprofits helps stakeholders, including local communities, consumers, workers, and suppliers, and also protects the long-term interests of firms. Exposure to these ideologies may contribute to the higher emphasis on the work value of giving to black museums among corporate patrons in a couple of ways. First, these ethics offer a script for thinking about black museum patronage as a professional duty. Enlightened self-interest also offers a framework for emphasizing the professional benefits of black museum patronage.

Finally, the overlap between the skills and knowledge of corporate patrons and those needed by museums may also play a role in corporate patrons' higher emphasis on the professional value of giving to black museums. More and more, the management practices of businesses are being incorporated into museum administration (Janes and Sandell 2007, 1-14; Ostrower 2002, 79-80; Zolberg 1981, 103-125). This means that there is a growing need for the skills and knowledge of corporate professionals in areas such as finance, law, and marketing. Thus, there is an objective reality whereby the professional skills and know-how of entrepreneurs and executives are increasingly aligned with museums' needs. This may also contribute to business patrons' stronger framing of giving to African American museums as having professional value.

In the next several sections I elaborate the often heightened emphasis that corporate supporters place on the work value of black museum patronage. We will see how understandings of giving in relation to work are often highly concretized, rooted in professional ties, and encompassing of both altruism and self-interest. In the final section of this chapter, I briefly describe how professionals who work outside of business lightly reference work in their explanations of the value of giving to African American museums; these references tend to be more individualistic and generalized.

\section{Doing good: Jobs}

For some trustees and other patrons who work in business, supporting African American museums takes on significance as an extension of their jobs. More specifically, their commitment to giving is inextricably linked to their firms' commitments to giving. One manifestation of this shared worker/ firm commitment is sitting on the board of trustees. Some firms have a longstanding relationship with a particular African American museum, so that an 
executive at the firm typically sits on the board. While this firm seat is not formally designated in museum bylaws, there is a shared informal understanding that when someone at the firm vacates their seat it will be inherited by another executive at their workplace. In some cases, this board inheritance has existed since the museum's establishment: not just the individuals who work at the firm, but the firm itself is considered part of the museum's founding team. In other cases, the inheritance takes place not because of a shared expectation that the firm will have a seat on the board, but rather through more informal network mechanisms such as the recruitment of trustees via professional ties. One trustee describes how he came onto the board in this fashion. "The partner who brought me into the firm, we knew each other for a long time. He was on the board and he had me replace him," he explains.

A lawyer describes how her law firm has a long history of engagement with the local community. Because of that involvement, one of the firm's founders was also a founding member of the museum board. She replaced him after he rotated off.

Henry Johnston [the firm's founder] was on the board. When I joined the firm, he had been on the board for a while, I guess, and was interested in rotating off. But, [he] felt it was important for someone in our firm to keep the connection, and they [the museum] of course like to have a lawyer on the board, and he [Henry] suggested me.

Passing down board seats within firms is in some ways analogous to the inheritance of museum trustee positions within families (Ostrower 2002, 12) ${ }^{4}$ Here, inheritance takes place within the firm. Even during the relatively young existence of the National Museum of African American History and Culture (NMAAHC), there is evidence of firm reproduction on its board. Brian Cornell, the CEO of Target, joined the advisory board in 2015. His tenure began after Gregg W. Steinhafel, the previous chairman and CEO of the company, served from 2010 through 2014.

Part of the reason that executives are recruited to black museum boards in the first place is the expectation that they will view their personal service as part of their firm's service to the community. Or, that by recruiting executives, they are also de facto recruiting firms. This means that museums will have access to not only the personal resources of executives but also the organizational resources of their firms. A long-standing adage on cultural and other nonprofit boards is "Give, Get, or Get Off" (Ostrower 2002, 66-68). Board members are expected to donate money and other resources themselves and/ or recruit others in their network to give. A failure to do so means that it is appropriate for them to be replaced. One place that business supporters turn to for "getting" is the firms that they own or that employ them. As one trustee explains, "Typically, you know that when you're being asked [to join a board] that you're going to be asked to commit some resources, either personally or corporately." A trustee who serves as an executive at a large corporation in 
her city, and who has brokered major donations from her firm to the African American museum where she sits on the board, describes how trustees are recruited with this ethos in mind: "There are some people on our board who everyone acknowledges are on the board because of a particular reason," she says. "Maybe they're at a company and that company is really important to us, and the company is a big contributor and so we need that person there."

A partner at a law firm explains how firms like his own will support the philanthropic activities of employees:

The rule of thumb typically at this firm, and I think most law firms, is that if you're on the board of an organization, then the firm will help you to support that organization, almost whatever the organization is. You have to be out of pocket some yourself, and then the firm will help support it.

Participants who work in business often emphasize how supporting African American museums is part of the broader commitment their firms make to supporting the public good. They describe how their firms exist in a broader ecosystem and have a responsibility to contribute financial and other resources to ensure that it functions optimally. This philosophy of corporate social responsibility is seen as an important cultural trait of their firms. When I asked one trustee about the relatively high level of support that his museum receives from the corporate community, he notes that it is motivated by a corporate social responsibility ethos. "Most of the funds that they give come from their foundations, and it's in keeping with that notion of being public citizens," he says.

By supporting African American museums, patrons who work in business give life to this ideal of their firms. They personally become the vehicles through which their firms manifest the value of corporate social responsibility. However, for many the significance of giving is not only wrapped up in being a representative of the firm's goodwill toward the community, but it is also linked to an overlap between their firm's pledge and their personal commitment to service. As the following exchange with a Dan, a corporate lawyer, indicates, sharing a giving ethic with their workplace is especially meaningful for some participants because it aligns their personal values with the values of their firms.

PATRICIA: Has this firm supported the museum at all?

DAN Yes, we've been continually supportive. I mean pretty generous too. Probably $\$ 5,000$ to $\$ 8,000$ or $\$ 10,000$ a year.

PATRICIA: And do you play a role in that?

DAN: Yes, and thankfully I've got an "in" with the current managing partner in the Lanham City office, I say facetiously. I mean it's always been very supportive. But Jeff Simon's the head of our office right now in Lanham, and he's got the purse strings for stuff like this.... One of the reasons 
I'm here, is [the law firm's] history of giving back to the community. The support, the importance they place on civic and community involvement, it's always been a part of it. We're now 100 years old in the city, and from the get-go, people who have been the leadership of the firm have felt it sort of integral to who we are-that we're a part of the community. So that's what we do.

Given his personal interests in community engagement, this trustee appreciates that his law firm shares this commitment. For supporters like him, a personal-workplace overlap in philanthropic interests deepens their sense that giving to black museums is an activity that is linked to their jobs. An ethos of corporate social responsibility also underlies the black museum trusteeship of Harry, who is a manager in his family-owned firm. His father began the business in the 1960s, and now Harry, as well as some of his siblings, helps to run it. Harry describes his philosophy of corporate social responsibility for black-owned businesses. In his view, they have a specific duty to support organizations in the black community. His family business is "involved a lot" with organizations like the Urban League and NAACP. They also support the museum where he is a trustee. "As the company grows, part of my vision is to have us more involved [in the museum]," he says. "I think it's really important that businesses, particularly in our community, support our institutions across the board. So it's not just the NAACPs, the Urban Leagues-it's not just the HBCUs [Historically Black Colleges and Universities], but it's also what I call cultural museums and cultural entities that help our advancement," he reflects. Harry's perspective aligns with other evidence suggesting that for black entrepreneurs corporate social responsibility is often particularly defined in relationship to the black community (Edmondson and Carroll 1999). For example, in a Wall Street Journal survey of 472 black business owners, 86 percent answered "Yes," that as "a black businessperson" they have a "special responsibility to contribute to the black community" (Carlson 1992, R16).

For supporters who work in business, the moral imperative to "give back" is not only often framed in relationship to their workplaces, but also their broader professions. Next, I discuss how the broader professional contexts that corporate patrons are embedded in are linked to how they define the value of black museum patronage.

\section{Doing good: Professions}

For many patrons who work in business, the ethos of corporate social responsibility is understood not only in reference to their workplaces, but also to their professions at large. More specifically, they view giving to black museums as articulating collective professional values and as nurturing professional relationships. When I interviewed Janet, who is an executive in a 
large corporation, she said that one of the central reasons that she was asked to join the board was that she is "a top executive with one of our major local companies." Clarifying why being in the corporate community is an asset for the museum, she notes that it gives her access to "money and the ability to pick up the phone and call other business leaders."

Janet understands that she is valued for bringing money to the boardnot only the money that she can personally give but also money that she has access to by virtue of being an executive. As a member of the business community in her city, she can mobilize the resources of the sector on behalf of the museum. Earlier I discussed how supporters in business understand their role as getting donations from their firms. Here, we see that another dimension of patrons' informal and sometimes formal obligations to raise money for museums is to get money from the broader corporate community. They leverage their relationships with executives outside of their firms to raise this money. For example, one of the board members of the NMAAHC, Robert L. Wright, began the stream of large corporate gifts to the museum when he helped to broker a one-million-dollar gift from Aflac. Wright, who at the time was the CEO of Dimensions International and chairman emeritus of Sentel Corporation, was also a board member at Aflac. The firm made the pledge in 2002, and it was the first major corporate gift to the museum (Trescott 2002).

Research on corporate interlocks describes how the business elite are interconnected with each other through service on corporate boards (Domhoff 2013[1967]). Corporate boards are a pipeline through which information and other resources are exchanged and shared values are nurtured. Michael Useem's (1984) research on the "inner circle" specifically delineates how these networks are a vehicle through which norms about corporate philanthropy in the arts are established. For corporate trustees who sit on the boards of other firms, their ties are an important source of social, and ultimately economic, capital for African American museums. As Pierre Bourdieu (1986) describes in his research on the various forms of capital-for example, cultural capital, economic capital, and social capitalone form of capital can be transformed into another. In this case, corporate social ties, a form of social capital, are transformed into economic capital, or donations to African American museums.

Even beyond corporate boards, ties in the corporate community can facilitate black museum patronage. One trustee who is an entrepreneur describes how he was recruited to his museum after attending an event put on by an organization for business professionals in his city. "I came to the museum to listen to a talk by David, who is the former CEO of TLA," he recounts.

It was a Corporate View [a local professional business association] luncheon. It just happened that they rented a space in the museum to do the luncheon. During the course of the luncheon, David, who at that time was probably still a board chair, invited anyone who ... wanted to 
learn more about the museum to contact him.... Over the course of the lunch, I was telling him about my involvement with an international nonprofit. I was very active here at the local level. One of the challenges that I had in working with people who needed some kind of emergency assistance was taking them from being in a position where they were receiving need, to one where they would be inspired to be able to take care of themselves. So in that conversation with David, I said, "I'd love to be able to pursue something along those lines as a part of the museum story." David Howe is known for making snap decisions, and that's the first time he had ever met me. He didn't know anything else about me other than what I had said, and he said, "Would you like to be on the board?" The rest is history.

A central ethos of the business community in this trustee's city is that members are socially responsive. Or, they act collectively for the public good. By serving on the museum board, this trustee is participating in this shared moral endeavor and thereby deepening his own links to his profession. Peter, a lawyer, describes a similar collective commitment to doing good among colleagues in his city. A few years ago, a professional group he belongs to established a fund in his honor at a local black museum. "The creators that made a contribution to the fund were colleagues of mine ... and they knew of my interest in civil rights," he says.

As a consequence they honored me with that contribution a number of years ago, and we began using it for educational purposes. It was called the Nadel Fund, and the purpose was to educate the community, mostly the younger people, of the civil rights movement. ... So, that really is how I became interested in the museum, more specifically. I'd always been interested in it, but that was the real beginning of my involvement.

Years later, when the museum was undergoing a major capital campaign, he helped to spearhead a fundraising drive among other professionals in the area. His firm was among several in the city that supported the effort with a financial donation. "My law firm gave $\$ 75,000$ or $\$ 80,000$ itself," he notes. "I'd say 75 or 80 , but a lot of us gave individually in addition to that. A lot of us in the firm gave. We had a significant number of individual contributions." A friend at another firm who also participated in this initiative notes how it was embraced by colleagues across the city. "Everyone was interested and then when they found out the other ones were interested, then they were very interested. You know how competitive we all are," she says lightheartedly.

An executive who is responsible for his corporation's philanthropic endeavors also notes the shared ethos of giving back in his city's corporate community. He joined a black museum board at the urging of a colleague who works at another business in the city. "I got involved at the invitation 
of one of my colleagues who sat on the board. Bria ran community outreach for Eastern Bank, so one of our competitors, but [we are] colleagues as well," he explains. Both his firm and the competitor firm have made donations to the black museum. Working with other firms in the community around philanthropy is not an atypical aspect of his job. In fact, he consults with colleagues at other firms to decide where they will lend their support. "We've partnered on a number of different things and this [involvement with the museum] was just an extension of that partnership," he explains.

Oftentimes, there is just too much work to be done by a single organization. So the work that I am doing in corporate social responsibility and community outreach is probably one of the few areas where [firms in this industry] are collaborators and not competitors. Since we all have the ambition where we are trying to create prospering economies where we live and work and play, we find it sometimes good that we can work together. There are a lot of synergetic opportunities that bring us together. Either because we see that there is a problem and there's not enough resources. Or, there are compelling regulatory reasons why we should be joining force. But in either track, we typically find ways to work together. ... We do believe that culture and arts are part of the cultural fabric that builds our communities, and to some extent, [are] as important as some of the more traditional endeavors around economics.

Useem (1984) describes such inter-firm collaboration around philanthropy as "contribution setting." Executives across different firms identify the appropriate nonprofits to support and the levels at which they should be supported. Given its collective nature, "caring capitalism" (Barman 2016) is a practice that comes to define membership in the professional community. ${ }^{5}$ To not give to nonprofits in their local communities would compromise executives' and firms' moral standing, and ultimately their legitimacy, with their corporate peers.

The strong sense of professional community that business executives and owners often describe in relationship to black museum patronage is often not as great among their peers who do not work in management. This is illustrated by the comments of a technical professional who works in a corporation. While this technical professional works at a business that sponsors activities at the local African American museum where he is a member of a support group, he complained of not being invited to a major fundraiser that is spearheaded by the city's business elite. As a collector he is keen to be involved in the full range of events at the museum. But, because he does not work in the executive ranks, he feels excluded from some events. "They [the museum administrators] have a gala, which we [he and his wife] aren't permitted to go to. It's just for the business community," he says. 


\section{Doing well by doing good}

They are trying to attract the businesses. We have complained about that, but so far to no avail. They [museum staff] said we could go, but we have to buy this table of ten. That is a bit too pricey. This idea of let's go after the corporate sponsors and ignore the people in between kind of bothers me, but I still support them. Everybody should be invited to all of their events and have equal opportunity to participate.

Even though he works at a for-profit organization that supports the museum, his lack of invitation to this major fundraiser emphasizes a feeling that he is not at the center of the business community. Other professionals also mentioned that it is executives who are the most integrated in their firms' philanthropic activities and who have the most power to make decisions about which nonprofits receive firm money.

For supporters who work in business, access to firm money and membership in the corporate community are not the only lenses through which they perceive the value to their work lives of giving to black museums. They also understand the value of their giving in relationship to the distinct professional skills and knowledge that they can offer to black museums. Museums rely on a range of skills and knowledge to function optimally. Some of this know-how overlaps with corporate professionals. Exhibitions must be marketed to the public, funds must be managed, and staff must be organized. Supporters who work in business can offer these skills to African American museums. Janet, who earlier stated that one of the reasons she was asked to join the board was because she could provide money further elaborates how skills and knowledge are part of the distinct package of resources that corporate supporters bring to African American museums and other nonprofits.

For any nonprofit, you look to try to have business leaders on your board for a number of different reasons. One, they bring certain talents to the table depending on the nature of their work, like HR, for example. Money. If the Civil Rights Cultural Center has a gift from Green Enterprises [her company] that lets them leverage that by going and sitting down and talking to another corporation. Volunteers. Depending on the nature of the organization, a volunteer base. So there's any number of reasons that you would want corporate members on your board.

Janet's point is brought into focus by the comments of a marketing executive who describes how her unique contribution to her local black museum board is her marketing skills and know-how. "I know so much about marketing and communications and public relations with advertising that I use that to support the organization," she reflects.

I have tried to participate in helping write a strategic plan for the whole organization. Keisha Cook [another board member] and I kind of 
partnered to really look at, "Why should the museum exist? What are we trying to do now and in the future, and What are the things we need to do to get to that future?" We tried to articulate this vision. ... It was really kind of branding. I tried to lead a branding thing without spending millions of dollars or even hundreds of thousands of dollars to really articulate who we are, what we want to do, and to create a look and feel that would communicate the distinctive nature of the organization. So, it's those kinds of things that I try to help bring and do. We came up with a new logo.... A very important part of getting people to give is to communicate visually the image and spirit of an organization so that people feel this sense of connection, and also that it's beautiful. It's an emotional bond. So anyway, I tried to contribute to that and to put together a plan.

This board member sees her marketing skills as a unique contribution to the museum. An entrepreneur who works in staffing sees his specific contribution to the museum where he is a trustee as falling in his area of expertise. He describes how he has helped the museum with hiring and firing employees. "In general, most nonprofits lack the resources to attract talent. Because they're nonprofits, they just generally don't pay well. So I currently head up our HR [human resources] committee," he explains.

Myself and the former chair of the board are the two members of the HR committee. There's been a lot of turnover. We had [a staff member] leave for a position in Boston in the last five or six months, so we hired a new person. We had to hire someone from the New York market, and we had to talk about our compensation package, what we offer her, how we bring her on-whether it was a contractor ... an employee. We've had to terminate people. I'm in the employment business and so that's the value that I've been able to add [to the board] from my perspective and what I do on a day-to-day basis.

These trustees view the black museums that they support as relying on their professional expertise. Entrepreneurs and executives in the forprofit sector also often note how they are in an optimal position to offer guidance about how to run African American museums. During the course of interviews, it was not uncommon for them to offer commentary related to how museums should be managed. Areas such as the productivity of staff and level of attention to the bottom line were at times critiqued or praised.

One trustee describes how a "corporate view" is essential for good management at black museums. In his mind, the black museum where he is a trustee has not been operating at an optimal level. However, because the board now has more people with a corporate perspective, he is cautiously optimistic about the museum's future. "There's enough people who are 
now involved that understand the corporate side of it-where it's objectives, where it's measurable, accountable, all those things. It's not just a nice feeling," he reflects.

I think there's at least an interest in moving in that direction. ... We haven't reached that point where the rubber kind of meets the road, but I think there are going to be some board members that are going to self-select or be selected off and there's probably going to be some staff members that are going to self-select or be selected off. But, it's the objectives. The objectives that we want are going to drive our activity, and it's purely about meeting the objectives. That's what I'm hoping to instill in our movement going forward. ... My goal is for us to be really, really good at what we do. Exemplary exhibits, exceptional sense of service and customer service, strong financial background, and aggressive marketing and fundraising.

Other supporters in business also emphasize the value of focusing their professional lens on operations at African American museums. Some see bringing insights into how museums can generate profit as their unique contribution. One supporter who works in sales talks about how her museum could bring in essential revenue through sales-related activities (see Figure 3.1). "We need to develop more strategies to increase earned income," she says. In her mind, charging more for facilities rentals and opening a café are ideas to consider for boosting income. An executive who sees the "business perspective" that she brings to her trusteeship as an important asset also reflects on increasing earned income. "I also think that we have to have a better earned income strategy," she says.

That's my whole entire thing coming from a business perspective. I'm like, "How are we self-funding?" I think every recession is a great reminder to ask, "What are we doing to generate revenue?" I think that has to be a very important piece of the dialogue.... All museums across the country need to ask, "How are we self-funded so that we can sustain during good and bad?" I think one of the things that we experimented with was our store. For so many years, that was something that was neglected by previous individuals. They just didn't see it as a big thing. ... But, we saw such a big pickup because we are like, "No, no, no we want unique high-end stuff-things that you can't get everywhere." And we did extremely well. ... It tripled what we originally anticipated that it would get just because we were very strategic.

This supporter has faith that a better approach to sales and marketing will improve the financial situation of her museum. A patron who works in sales also emphasizes how the museum he supports should apply the market principles that he has honed at work. "When we come in here, it has to be business," he explains. "We have to push hard and strong and fast, and be 


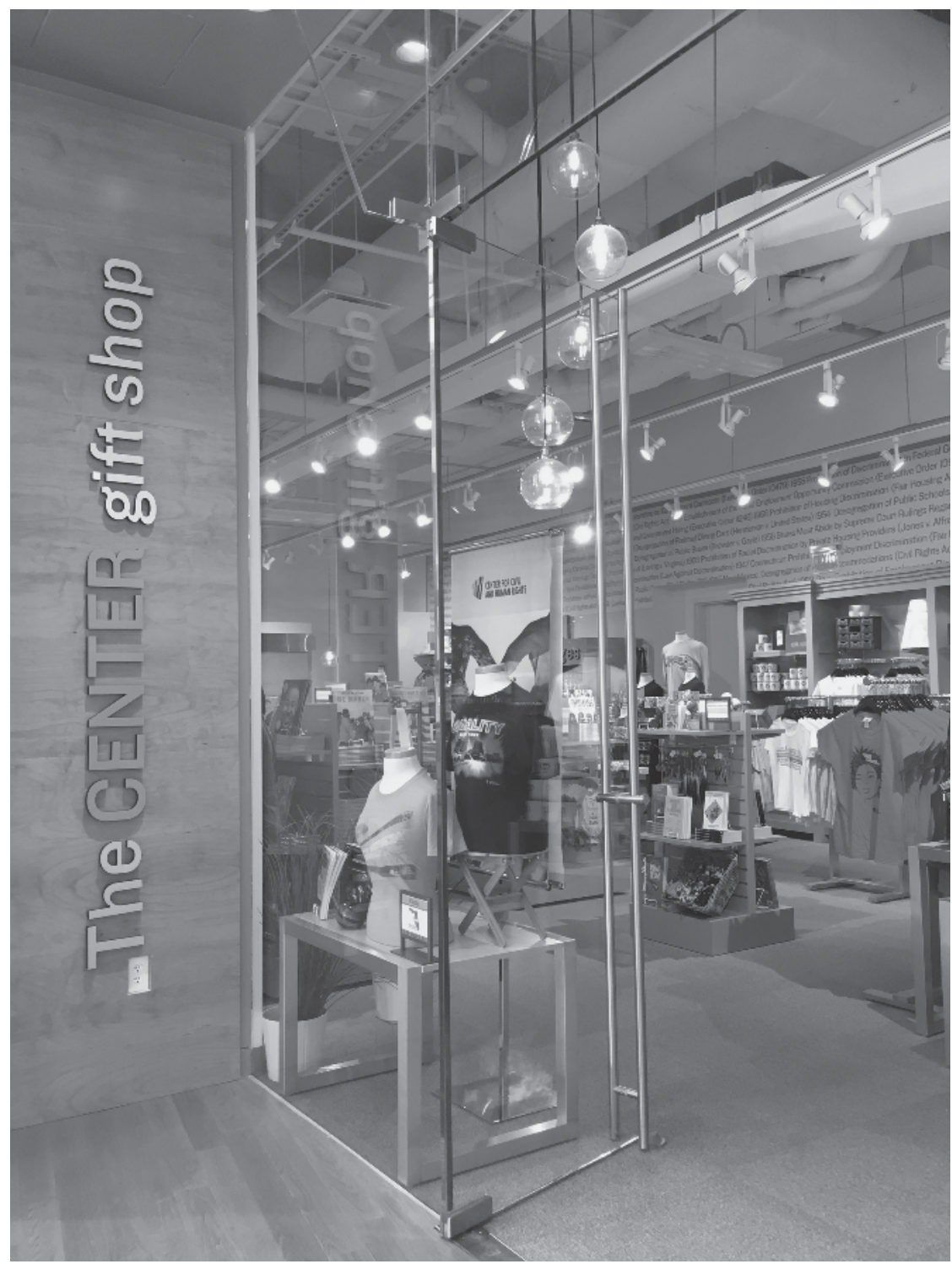

Figure 3.1 Gift shop at the National Center for Civil and Human Rights, Atlanta, Georgia.

all about the customer-tracking data on our visitors and how many visitors we are going to get the next time."

Across the nonprofit world there is increasing emphasis on using a for-profit corporate model to manage and evaluate nonprofits. This view emphasizes that nonprofits should be transparent, efficient, and market 
oriented (Strom 2010). Having a market orientation means not only that close attention needs to be paid to income, but also that audience members and donors are a kind of customer that museums need to satisfy. One major development in the field that both reflects and reinforces this shift is GuideStar. Founded in 1994, GuideStar aggregates IRS 990 Forms from thousands of nonprofits, including museums, on its site. Drawing on this and other data, reports are produced about each nonprofit. The reports include facts and figures detailing financial and other information. "With GuideStar and the like, nonprofits can't hide anymore and that's good," one entrepreneur commented. Independently, some museums meet expectations for transparency by posting in-depth organizational information, such as annual reports, on their websites. One trustee who works in business expresses frustration that the museum he supports is not one of these nonprofits. "The public needs to see that the museum is viable to make a substantial investment," he says. In his view, a well-functioning organization, with transparency about its financial and overall health, is what gives potential donors confidence that they are making an investment in a museum that will thrive. $\mathrm{He}$ believes that disclosing and widely disseminating financial information, through means such as putting annual reports online, is essential for building public confidence.

\section{Doing well}

On the one hand, supporters who work in business often emphasize how their support of African American museums is linked to broader values of corporate social responsibility. Through giving they articulate an ethos of "caring capitalism" and contribute to the well-being of their communities. Yet, social value is not the only frame through which corporate supporters understand their philanthropy. There is also often recognition that their patronage can indirectly and directly positively affect their careers. ${ }^{6}$ As one supporter succinctly said, "Giving is good for everyone-the community and the company." The first part of his comment is reminiscent of statements that we encountered earlier: philanthropy by the corporate community is driven by a desire to contribute to the public good. However, the latter part of his statement shines a light on the other side of this giving. While on its face philanthropy in the corporate community may seem entirely altruistic, it is also motivated by a desire to protect the welfare of executives and firms.

Some supporters who work in the for-profit sector see patronage at African American museums as protecting their career interests by encouraging networking. A museum staffer described how making professional contacts via her museum is especially important to corporate supporters. For some, patronage is "more of a networking kind of situation. The artwork is still sort of secondary," she explains. Prospective patrons who are considering whether or not to participate in museum events "want to know 
who is going to be there because they are thinking about their business career," she reflects.

Networking often takes place at museum fundraisers. Earlier I described how there is an understanding that those in business will leverage their personal ties to fundraise for the museum. However, relationships that are nurtured in the context of black museum patronage are also a form of social capital that can be of professional value to corporate supporters and their firms. First, supporting these institutions is one mechanism through which relationships with others at the same firm can be reinforced. This became clear when I asked Daryl, who works in finance, whom he invites to museum fundraisers. Daryl, who is in his early 40s, explained that while he now sees the major fundraiser for the museum where he is a board member as an opportunity to "kick it with his homies," in the past he saw events like this as a chance to forge connections with those at his workplace.

PATRICIA: So you were saying that one of the things that happens with some of the events is that you buy tables. Who are the types of people you would invite?

DARYL: I think in the past it was more strategic: "Who do you want to get to know? For whom would this be a sort of a mutually advantageous relationship?" ... Yesteryear, I might have tried to get somebody from a different division who I wanted to get to know. "Hey, I have a table. Here are two seats for you and your wife. Let's get to know each other."

As his career has matured and is more secure, Daryl feels less of a need to use the event for strategic networking. "Today I have no room for that," he reflects.

If our paths are crossing organically that is [great], but I am not forcing it and I am not trying to smile for the camera. ... I am not in that place in my life where I am courting people who I don't know for a strategy. No, I'm all past that. There is a time and a place for that. When I was 24, I didn't know anybody. ... I think that's a process that everybody kind of goes through. I feel like I went through that in a deliberate way such that now I am home. I am home. I have enough life and career progress just from my own affiliations and I believe in that.

Unlike Daryl, Wilson, a member of a friends' group, does currently use his patronage to cultivate professional relationships. Wilson describes how he was introduced to the museum that he supports by a colleague who also works in management at his firm. "We share a lot of common interests, and she thought this would be something I would be interested in, and she's absolutely right," he recalls. Becoming involved with the group not only nurtured his relationship with his colleague but also brought about "opportunities for collaboration on a professional front" with others in his field. 
"I make it a point to make one contact at each event and then to follow up later," he explains. Other corporate supporters also describe how patronage at African American museums has helped them to connect with colleagues outside their firms. A newly appointed trustee who works in business notes how his museum's recent gala was an event where attendees were "all there for a good cause" but also there "to do some networking."

I wasn't a part of the gala committee so I didn't know about some of the sponsors-some of the companies-that were going to be part of the evening. But, Jacob Hills, the CEO of Hillstop, was there. To actually run into somebody from there, just to have a conversation about our [mutual interests] was really cool. ... The gala created a situation where it was very easy to network. If you felt like having a conversation and meeting some new people, you could. If you felt like just enjoying the vibe, you could do that as well.

When I ask him if he will follow up with these new contacts he responds, "No, I actually should have gotten their information. I probably could have done a bit of a better job actually networking, but I think there will be another opportunity. I know I'm going to see these people again.” Although this supporter did not formalize any professional connections at the event, an entrepreneur describes how his business mentor encouraged him to join the black museum board where he is a trustee to build his professional network. When I asked him how he first got involved in the board, he responded that it was at the urging of "a mentor of mine" who has "been on the board." "He's a successful businessman on the board of many museums ... and so he was trying to encourage me to get involved in more art institutions, and we thought this museum would be appropriate," he explains.

He basically suggested it might be a good idea for me to be on the board, and he introduced me to the current chair of the board. So, you find your mentor, and you kind of listen to what they say and take their advice. I thought it was a great opportunity that he presented by suggesting I join and introducing me to the chair of the board. I met with the president of the board and got a sense of what the museum was about. I [also] met with the CEO of the museum and took a tour of the museum. I tried to understand what they were trying to do and how that might fit with my experiences and how I'd be able to help.

He further clarifies why museum trusteeship is helpful for building his professional network. "As a business owner here, or anywhere else, you're always trying to build relationships," he says. "You want to develop more relationships to grow." One reason in particular that he sees this museum as useful for building his professional network is that the board has regular events with trustees of large majority museums in the city. These boards 
are led by the city's business elite. "With my business interests in this city, it made sense to get involved with the museum because of the relationships that I would form with the Greenston Museum of Art [a majority museum and the largest fine art museum in the city]," he clarifies.

For example, we had a board meeting on Thursday. After our board meeting, we had a mixer with the board of the Greenston Museum of Art. We've done that with the Museum of Modern Art, Greenston as well. So the boards of the museums often get together and socialize with each other. Our board is not functioning in isolation. We keep in contact and have relationships with boards of other art museums and art institutions in the city. So, there's a community of board members from the different art museums that have a chance to interact.

This supporter joined the board not only to build his professional network, but by taking the advice of his mentor, he was also nurturing their relationship too. Corporate supporters also describe how relationships with clients can be forged through museum events. One trustee whose path onto a museum board was via a business relationship says that while it is not the case for him, it is common for others to actually join to form such ties.

The specifics of how I became involved with the museum in an official capacity came about as a long-standing relationship I have with an attorney, Jack Stapper, who's been on the board for I think a year longer than I have been on the board. I've worked with him in lots of different client situations, and he was the one that really called and asked me if I'd be interested. First, he brought me to some events, and then he said, "Would you be interested in stepping onto the board?" ... Since that event one of my clients has now joined the board. So, I do have business relationships on the board although that was not my intention and continues to not be my purpose here. I think a lot of people join boards so they can sign up everybody on the board to be their clients. I don't make any attempt to do that. I don't have any interest in doing that. If it happened, it would happen. But ... no one would feel like they had been approached by me to do any work for them. ... That's not why I'm here.

Black museum patronage is considered by corporate supporters not only as an activity that nurtures professional ties by physically bringing them together with colleagues and clients, but also as a way of embedding them in a system of reciprocal philanthropy. One trustee describes how in his city there is a kind of philanthropic quid pro quo that operates in the corporate community. If a client or colleague asks you to contribute to a nonprofit for which they are fundraising, it is expected that you will give. ${ }^{7}$ However, it is also expected that down the road, when you ask them to give to a cause that you support, that they will contribute. In this way, philanthropic gifts flow 
through networks of exchange that reinforce professional relationships. "Sometimes, even if you don't want to do it [donate], if the client asks, you do it," a corporate supporter explains.

I'd say as a firm [we] get hit up all the time with our corporate clients saying, "We are going to support this and we expect you guys to support this." So we do. You know how that works. So that happens a fair amount. ... I have been able to get some of my friends to support the museum, and in some cases, it's a quid pro quo. I'll do this for you, if you'll do that for me. Not always, but sometimes. There is this one guy in particular, he roped me into supporting the YMCA... They have an annual golf tournament, and it's not inexpensive. I did it for him, so I've been roping him in to supporting the museum.

In cases like these, solidarity is forged within the business community by entering owners, workers, and clients into a system of reciprocal philanthropy. It is a form of gift exchange where the recipients are asking not for themselves, but rather for their chosen nonprofit. To not reciprocate is to risk a loss of not only face but also the relationship. ${ }^{8}$ A trustee who spoke at length about an ethos of community responsibility at her law firm also noted how her firm's founder saw philanthropy as a strategy for building business. "I think Mr. Johnston thought that, number one, it was your obligation as a lawyer to do it [join a nonprofit board] because lawyers are useful," she says.

There is not a nonprofit board around that can't use a little free legal advice. So, it's always nice to have a lawyer on a board because they can advise on legal matters. I like to think most of us are logical thinkers, so he thought that it was important that we had ... a part to play in that. But, he also thought that you really couldn't be a good lawyer if all you did was practice law. You needed to be out in the community to know what the issues were. It was a way of getting business. Being down in the community and meeting people of like minds, that kind of thing. I think it's really a tremendous benefit to all of us that he felt that way. I remember when I was a young lawyer and he was still alive he was in a snit one day and he said, "I want every single lawyer in this firm to send me a list of the community activities that you are involved in, because if you are not, if you are not involved in any, you better get involved." Luckily, I was. I had a couple of things that I could put on my résumé so I wasn't too scared. But, he just felt very strongly about it and there is really nobody here who doesn't get involved in something.

The leadership at her firm takes a position that building a customer base requires not only making connections with potential clients in the community, but also reading the pulse of the public. Both, in their view, are facilitated by nonprofit trusteeship. A law firm partner further elaborates on 
the role that giving can play in building clientele. "Some people look at it [serving on nonprofit boards] as just rubbing elbows with people who can become clients," he explains.

That's part of it. [Also], the goodwill will mean something. So, when people think of our law firm, they think of it positively because of things that we do in the community. ... Whenever I have clients who have any interest, we go down [to the museum]. A lot of my clients are from out of town. We try to go there. So, I've done that many times. It's a point of pride for this city, and if we have shared interests it's sort of building a relationship based on something other than what I'm doing for them in the business world. They just love it. ... They have a special opportunity, because generally speaking when I do that, I have the head of the museum provide a tour where everything comes to life. I'm not sure if someone off the street who walks in there is going to have the same experience because they won't have the right person showing them around.

It is with wooing clients in mind that another supporter lauds the new meeting rooms at the museum where he is a board member. "If [a corporation] is bringing in a group of its execs or management folks, and they want to have a meeting off-site, they can do it there at the museum," he explains. "The corporations will rent space in the museum now that we have adequate meeting space, and as part of renting space they can get the private tours of the museum." Professional ties can be deepened by bringing coworkers and clients to museums for meetings and private tours. But, as David, a trustee who works in sales, describes, sponsorships can also facilitate relationships with future clients. "[Sponsorship] is exposure for me as a businessman," he says.

I actually sponsored an event where [an artist] came to the museum. ... They let me thank everyone for coming, and I met a woman there. She came in two weeks later with her husband, and they were so happy to actually know someone at the retailer before they got there.... They had been obviously debating getting a [car] for a while. The guy bought a $\$ 90$ thousand [car] from me, and we made, I made, way more money than I did sponsoring the event. You don't know who's looking for your product or who's in the market for a [car]. It's why the mattress companies are in the newspaper every week or every day. You know what I mean? People are constantly in and out of that market. As a [car] company, you don't know who's going to be in the market. The woman who initially hooked me up with the first woman, she's bought two [cars] since then. And, one person who's a donor to the museum, he's on committees there. He's not actually on the board of the museum, but he is on the Capital Campaign Committee for the museum. He bought 
two [cars] from me in the last year, and his network has bought literally seven. Every one of them are over $\$ 110$ thousand, every one of them. So, you've got to be around. ... Being there for the fundraiser is the perfect thing to be at to just soft pitch and meet great people.

We have now seen how corporate supporters often frame the importance of giving to African American museums within the context of work. Philanthropy at African American museums is partly valued as an expression of corporate social responsibility that is grounded in firms and the broader business community. It is also given meaning as part of the system of reciprocal philanthropy that nurtures professional relationships in the corporate sector and as a tool to build instrumental career ties. Next, we will turn briefly to supporters who work outside the business sector.

\section{Noncorporate supporters}

In comparison to their corporate counterparts, noncorporate supporters tend to place less emphasis on the professional value of giving to African American museums. First, whereas the former often see giving to African American museums as part of a collective responsibility of their workplaces and professions to support cultural institutions and other nonprofits, noncorporate supporters are less likely to interpret their support as part of a shared obligation among their colleagues. For instance, they less often describe supporting black museums because it is a long-standing tradition where they work. When asked if anyone else in their offices gives to black museums, they often make comments such as "not that I know of" and "not that I can recall." The less work-centered patronage of noncorporate supporters is also indicated by their comments about inviting coworkers to fundraising events. As one noncorporate supporter explains, "I don't typically invite anyone from my office."

Fred is a trustee who works as an educational administrator. As is fairly typical of other noncorporate supporters, his workplace is not an institutional supporter of the museum..$^{9}$ Moreover, he does not describe his giving as part of a shared endeavor among professionals in his field. Rather, the link between work and his trusteeship is more philosophical and highly personal. ${ }^{10} \mathrm{He}$ describes how mentoring children is part of his life mission and professional calling. Through serving on a local black museum board, he is pursuing that charge. "I look at it [black museum patronage] from an education standpoint, because as you know, I am an educator by trade. So, I want to be a part of influencing the education programming throughout this community to help expose the next generation to black culture," he reflects.

I want to be a part of sharing that story. So that's why ... I approached them [the museum] and they said, "Come on the board.” ... I've always been a part of giving back in certain ways, especially when it comes to 
mentoring. I've always mentored young men throughout the community, especially when I worked in schools. I ran schools for twelve years prior to coming downtown to the central office. So with that I've had numerous mentoring initiatives that have been successful. ... I have been to numerous schools and at each point it was life-changing for kids. So I've always seen the value of giving back and seeing the world not just through a "me standpoint," but "What's my duty and role to society? How do I help others?" So, I do that on an individual basis-working with children. But, I've also always wanted to give back to the community in a larger context. Some can say that I do that with my job. But, that is a job. I think through the volunteering at the museum, that is where I am able to give back, and in a way we [African Americans] can tell our own story. That is really what I want to do because you don't need permission to share the story, and to capture it, and bring all the exhibits through. It is for African Americans, supported by African Americans.

Fred links his black museum trusteeship to personal and professional goals to serve the black community through education. Yet, unlike some of the corporate supporters we encountered earlier, he does not view engaging in museum philanthropy as a shared endeavor among his professional colleagues or as an activity that is instrumental for his career. He even sharply differentiates his employment and trusteeship by saying that while both are related to education, the former is a "job" and the latter is "volunteering."

For Nelson, who has worked as a judge and is a longtime supporter of one of the black museums in his city, the link between his patronage and job is also less salient than it is for some of the corporate supporters. In his free time Nelson is deeply involved in the arts as a musician, playwright, and art collector. At the museum, he is a trustee and involved with musical events. Nelson does not describe his museum patronage as part of a broader collective project of his workplace or professional colleagues. Instead, he links it to his personal passion for the arts and his belief that an "uplifted spirit" is necessary for community well-being. This is an ethos that he brings to his work and one that he sees the museum nurturing by giving him an outlet for his artistic interests and by exposing youth and others in the community to "emotionally engaging" art. This is apparent when he talks about his "law side and art side." "Oh, they go so well together. I am telling you," he says.

I believe that the art side is about community. It's about bringing people together. I think at least for the law side, that's about criminal justice, and all of that. What is the thing that is lacking in most people's lives who are involved in crime in the community? It's that belonging, that yearning to be accepted in your individuality-not tolerated, but accepted. I used to begin every day when I was on the bench-I would 
be in my lobby-and I would sing before I went on the bench ... so when I got on the bench, I would be ready for whatever came and nothing would bother me. I think that I would also try to transfer that spirit to all who were around me-the audience, the court workers, the attorneys, and the defendants.... But, I feel like the arts in me informed my feeling about justice and judging and lawyering and everything that I did.

Nelson views music as part of his repertoire of work tools. In this way, his cultural patronage and work life are intimately connected. However, in contrast to many corporate supporters, for him the link between his professional life and museum activities is largely individualistic. He has a personal philosophy about his identity—he has a "law side" and an "art side." His art side is cultivated via museum patronage and integrated into his everyday work practices in an individualistic fashion. He sings, and he sings alone. Also, in contrast to corporate supporters who describe highly objective career benefits to black museum patronage, for Nelson the career benefits are more indirect and diffuse. Black museum patronage is in line with his career goals in so far as it reinforces a dimension of his identity that he feels makes him a more effective worker. However, he does not see patronage as a vehicle to build instrumental relationships that will benefit his career.

It is not the case for Nelson or for many other noncorporate supporters that their museum patronage is understood completely outside of their work lives. However, the connection between their professional selves and black museum philanthropy is one that is more often highly personalized and less likely seen as bringing concrete benefits. For example, one patron mentioned that after becoming involved with her local black museum, she recognized an artist's work that was reproduced in some of the framed posters that hang in her office complex. "I was walking by them every day, but I didn't really notice or know the artist," she explains. While this newfound recognition could potentially help her to bond with others at work-such as talking about the reproductions with coworkers-she has not brought up the artist or posters with any of her colleagues. "It's just something that I noticed in passing," she shared.

Noncorporate supporters are also less likely to describe norms of reciprocity in their professional networks dictating that they support colleagues' favored nonprofits and vice versa. One noncorporate supporter who could not remember a recent time that she had been asked by a professional colleague to give to their chosen nonprofit was even surprised when I asked if she solicited colleagues to give to the local black museum that she supports. It is most often friends that she solicits for support. Noncorporate supporters also generally place less emphasis on their professional skills and knowledge as being an important resource that they offer to African American museums. For noncorporate supporters in certain fields, such as healthcare, there is simply little need for their professional capital in this 
setting. Even more broadly, the increasing emphasis on business being the best model for nonprofits also means that the skills and knowledge of corporate professionals are seen as especially important in this setting. For example, even though Fred works in an administrative position in education, he did not talk about his management skills and knowledge as something that he brings to his museum board.

Finally, noncorporate supporters diverge from their corporate counterparts by placing less emphasis on networking as a professional benefit of their black museum patronage. For noncorporate supporters, particularly those who are black, networking via African American museums is more often understood within the frame of connecting with other professionals or black professionals (the upper-middle and upper class as a whole, or specifically the black upper-middle and upper class), rather than building strategic relationships with people in one's specific profession. For example, an African American educator shared that he enjoys attending his museum's events because he meets other black professionals. "It's good to connect with other successful African Americans in the city," he remarks. However, he does not think about the museum as a place to build relationships with his colleagues at work. In fact, to his knowledge, he is the only person from his workplace that supports the museum in a substantial way.

To summarize, while noncorporate supporters may view giving to black museums as having a degree of connection to their professional lives, the emphasis that they place on the work value of black museums is typically less than their corporate counterparts. For example, they are less likely to describe fundraising events as a collective ritual for their workplaces. Similarly, they more often see giving to black museums as reinforcing workplace identities that are more individualistic in nature.

\section{Conclusion}

This chapter describes how supporters of African American museums think about the professional value of patronage. In comparison to other supporters, those who work in the corporate sector, especially executives, entrepreneurs, and lawyers, tend to place greater emphasis on its work value. Corporate supporters tend to describe giving to African American museums as an articulation of an ethic of community responsibility grounded in their workplaces and professions, as well as a practice that returns dividends in their careers. In contrast, noncorporate supporters' understanding of the professional value of giving to African American museums is more muted and personalized. Also, among noncorporate supporters an emphasis on "doing well" via networking is a less common frame and when applied is often understood as meeting others in the professional class as a whole rather than cultivating strategic ties that will bear fruit in one's specific field. I suggest that the distinctive emphasis on professional value among corporate supporters is partly grounded in the higher 
embeddedness of the corporate world, particularly the executive ranks, in African American museums and other nonprofit philanthropy. I also suggest that it is a function of the distinct cultural features of business, such as the ethics of corporate social responsibility and enlightened self-interest, and the skills and knowledge repertoires of corporate workers, particularly entrepreneurs, managers, and lawyers.

This chapter offers important new insights on class and culture. While the broader research on class and cultural capital distinguishes corporate workers from other members of the upper-middle and upper class, there has been less focus on profession within the scholarship on museum patronage. In Bourdieu's (1984) conceptualization of social class, classes are distinguished by both volume and composition of capital. Corporate managers are distinguished from other members of the upper-middle and upper class, such as professors, by their higher volume of economic capital relative to cultural capital (Bourdieu 1984). It may be the case that the high class status of corporate executives rests more on their stocks of money than of culture. However, this chapter demonstrates how, relative to some other types of upper-middle and upper-class professionals, corporate workers see museum patronage as more important for their jobs. Thus, while theory on museum patronage emphasizes how it is a practice that nurtures membership in the upper-middle and upper class, this chapter shows that, from the perspective of supporters, the class benefits of giving to museums are not uniform. It is corporate supporters who see themselves as getting the biggest professional returns for their patronage. In the next chapter, we turn our attention to another frame of value through which black museums are assessed: cultural value.

\section{Notes}

1 Supporters in cultural fields-for example, individuals with jobs directly connected to culture and/or history - who work outside of business also place high emphasis on giving to African American museums in relationship to work. However, given that cultural professionals' engagement with history and/or culture is typically part of a broader lifestyle of deep cultural engagement, I exclude them from the analysis in this chapter. Thus, this chapter compares patrons who do not work in cultural fields. While not a significant focus in this chapter, workers in the private sector, such as entrepreneurs, managers, and lawyers, tend to place more emphasis on work value than certain types of professionals such as engineers. The heightened focus on work value among the former is likely influenced by factors such as it is among the executive ranks that involvement in the nonprofit sector is especially high.

2 Although not all patrons who work in the private sector specifically work at corporations, for shorthand I sometimes refer to them as "corporate patrons" or "corporate supporters." At times, I use the terms "noncorporate patrons" and "noncorporate supporters" to refer to patrons who work in government and the public sector. 
3 In her research on over 400 cultural boards Francie Ostrower (2013) finds that business is the most common employer for trustees.

4 In her research on museum and opera trustees, Francie Ostrower $(2002,12)$ finds that some women take on board seats previously occupied by their husbands.

5 The sociologist Emily Barman uses the term "caring capitalism" to refer to corporate pursuit of “both money and mission” $(2016,1)$, or corporations' efforts to make a profit and a better society.

6 In 1970, the economist Milton Friedman wrote an essay for the New York Times Magazine that laid out an argument against corporate philanthropy. In the essay, Friedman argues that the core responsibility of corporations is to make money. Therefore, any gifts that compromise economic returns to shareholders are unethical. He does acknowledge that in some cases firms cloak self-interested philanthropy in the dress of social responsibility.

7 In his research on corporate philanthropy in Minneapolis, Joseph Galaskiewicz $(1985,1997)$ also finds that giving is influenced by peer pressure from other managers.

8 Research on gift-giving more broadly describes how it is a practice that builds social bonds and obligations (Mauss 1966).

9 In my sample of more than 2,000 large donations to African American museums, just a fraction of donations were from schools. A much larger proportion are from the corporate sector.

10 Although some supporters who work in education mentioned their schools' engagement with black and other museums for educational purposes-for example, to enhance school curriculum related to history and/or culture-it was much less common for them to describe high levels of involvement of their schools in museum philanthropy.

\section{References}

Alexander, Victoria D. 1996a. "From Philanthropy to Funding: The Effects of Corporate and Public Support on American Art Museums." Poetics 24(2-4): 87-129.

. 1996b. Museums and Money: The Impact of Funding on Exhibitions, Scholarship, and Management. Bloomington: Indiana University Press.

Barman, Emily. 2016. Caring Capitalism: The Meaning and Measure of Social Value. New York, NY: Cambridge University Press.

Bourdieu, Pierre. 1984. Distinction: A Social Critique of the Judgement of Taste. Cambridge, MA: Harvard University Press.

- 1986. "The Forms of Capital." In Handbook of Theory and Research for the Sociology of Education, edited by John G. Richardson, 241-258. New York, NY: Greenwood Press.

"Business Committee for the Arts Committee Members." 2018. Americans for the Arts. Accessed June 19, 2018. www.americansforthearts.org/about-americansfor-the-arts/business-committee-for-the-arts/business-committee-for-the-artscommittee-members.

“Business Group Formed to Rally Support for Arts.” 1968. New York Times, February 1, 1968. 
Carlson, Eugene. 1992. "Battling Bias: A WSJ Survey Finds that Barriers and Stereotypes Exist.” Wall Street Journal, April 3, R1-R16.

Datcher, Mary L. 2015. "Perri Irmer: A New Chapter for DuSable Museum.” Chicago Defender, September 23, 2015. ProQuest.

DiMaggio, Paul. 1982a. "Cultural Entrepreneurship in Nineteenth-Century Boston, Part 2: The Classification and Framing of American Art." Media, Culture, and Society 4: 303-322.

—. 1982b. "Cultural Entrepreneurship in Nineteenth-Century Boston: The Creation of an Organizational Base for High Culture." Media, Culture, and Society 4: 33-50.

Dingle, Derek T. 2012. “The \$250,000,000 Mission to Preserve Black History.” Black Enterprise, June 1, 2012. Accessed January 10, 2017. www.blackenterprise. com/the-250000000-mission-to-preserve-black-history/.

Domhoff, G. William. 2013[1967]. Who Rules America? The Triumph of the Corporate Rich. New York, NY: McGraw-Hill Education.

Edmondson, Vickie Cox, and Archie B. Carroll. 1999. "Giving Back: An Examination of the Philanthropic Motivations, Orientations and Activities of Large BlackOwned Businesses." Journal of Business Ethics 19(2): 171-179.

Friedman, Milton. 1970. "The Social Responsibility of Business Is to Increase Its Profits.” New York Times Magazine, September 13, 1970, 32-33, 122-124.

Galaskiewicz, Joseph. 1985. Social Organization of an Urban Grants Economy: A Study of Business Philanthropy and Nonprofit Organizations. Orlando, FL: Academic Press.

- 1989. "Corporate Contributions to Charity: Nothing More Than a Marketing Strategy.” In Philanthropic Giving: Studies in Varieties and Goals, edited by Richard Magat, 246-260. New York, NY: Oxford University Press.

—. 1997. "An Urban Grants Economy Revisited: Corporate Charitable Contributions in the Twin Cities, 1979-81, 1987-89." Administrative Science Quarterly 42(3): 445-471.

Janes, Robert R., and Richard Sandell. 2007. "Complexity and Creativity in Contemporary Museum Management.” In Museum Management and Marketing, edited by Robert R. Janes and Richard Sandell, 1-14. New York, NY: Routledge.

Lamont, Michèle. 1992. Money, Morals, and Manners: The Culture of the French and American Upper-Middle Class. Chicago, IL: University of Chicago Press.

- 2009. How Professors Think: Inside the World of Academic Judgment. Cambridge, MA: Harvard University Press.

Martorella, Rosanne.1990. Corporate Art. New Brunswick, NJ: Rutgers University Press. . 1996. Art and Business: An International Perspective on Sponsorship. Westport, CT: Praeger.

Mauss, Marcel. 1966. The Gift: Forms and Functions of Exchange in Archaic Societies. London, UK: Cohen and West.

Ostrower, Francie. 2002. Trustees of Culture: Power, Wealth, and Status on Elite Arts Boards. Chicago, IL: University of Chicago Press.

—. 2013. "Diversity on Cultural Boards: Implications for Organizational Value and Impact.” Working Paper, National Endowment for the Arts, Washington, DC.

Stendardi, Edward J. 1992. "Corporate Philanthropy: The Redefinition of Enlightened Self-Interest.” Social Science Journal 29: 21-30.

Strom, Stephanie. 2010. "To Help Donors Choose, Web Site Alters How It Sizes Up Charities.” New York Times, November 27, 2010. ProQuest. 
Trescott, Jacqueline. 2002. "African American Museum Plan Given \$1 Million Boost.” Washington Post, November 4, 2002. Accessed January 10, 2017. www.washington post.com/archive/lifestyle/2002/11/05/african-americanmuseum-plan-given-1-million-boost/d60ba9b3-3a7d-45d0-b4e0-f06a3f52da78/ ?noredirect=on\&utm_term=.0e71878550ce.

Useem, Michael. 1984. The Inner Circle: Large Corporations and the Rise of Business Political Activity in the U.S. and U.K. New York, NY: Oxford University Press.

Zolberg, Vera L. 1981. "Conflicting Visions in Art Museums." Theory and Society 10(1): 103-125. 


\section{The connoisseur's eye}

Kara Walker. Kerry James Marshall. Wangechi Mutu. The art collection of Marcus and Jacqueline Marshall includes work by these and other wellregarded artists. ${ }^{1}$ I spot some of the works when I walk into their brick home for our late morning interview, and they show me others during a tour before I leave. The Marshalls are collectors with a deep interest in contemporary art from the African diaspora. They spend their leisure time away from their busy jobs visiting galleries, hosting art events, and attending museum exhibitions. A central goal of their support of African American museums is to help remake the visual art canon so that it is more racially inclusive. Tom Kelly, who is also a black museum supporter, does not share the Marshalls' passion for art. He displays family photographs and signed sports memorabilia in his office, where I interviewed him. Other than his family membership at one of the majority museums in the city, Tom's position as a trustee at an African American museum is his most extensive involvement in the cultural world. And, unlike the Marshalls, whose black museum patronage is partly directed towards fostering the aesthetic mobility of black artists, Tom did not have rewriting the canon on his mind when he accepted the position to serve as a trustee. "I don't know too much about art," he confesses. "I really can't offer any expertise in that area."

This chapter explores how cultural connoisseurs like the Marshalls understand the cultural value of African American museums in contrast to cultural appreciators like Tom Kelly. Connoisseurs are distinguished from appreciators by their greater involvement in culture beyond patronage at African American museums. This lifestyle category includes individuals such as collectors of fine art and/or historical objects and those who work in cultural fields, such as gallerists and curators. Connoisseurs are typically motivated to become engaged in philanthropy at African American museums because of cultural interests, and they evaluate the cultural dimensions of these institutions with an eagle eye. In contrast, culture is a less central motivator of appreciators' involvement with black museums. Although they certainly evaluate African American museums along cultural lines, appreciators' judgments are less authoritative and lack the specificity of connoisseurs' opinions. ${ }^{2}$ 
By making this argument, this chapter contributes to several strands of sociological research on museum patronage. First, it offers a critique of the museum patron as connoisseur. Though some supporters are cultural experts, the connoisseur is just one type of African American museum philanthropist. This chapter also offers important insight into the evolution of African American culture as "high culture" and as a commodity. According to Paul DiMaggio (1982a; 1982b), the "cultural capitalists" who founded major cultural institutions in the 19th century not only contributed to social boundaries between classes but also established boundaries between various forms of culture. Fine arts institutions played a major role in sorting culture into that which is deserving of respect, or so-called high culture, and that which is unworthy and designated as "low culture." I suggest that there are parallel processes here in the context of patronage and black museums. Through the work of philanthropists to support African American museums, particularly that of connoisseurs who hold them to the highest cultural standards, African American culture is heterogenized and some cultural objects and producers are vaulted into the arena of the worthy. Moreover, through the lens of connoisseurs who emphasize the role of black museums for certifying the economic value of black cultural objects, we also see new connections between museums and markets.

\section{The love of culture}

In The Love of Art: European Art Museums and Their Public (1991), the French sociologists Pierre Bourdieu and Alain Darbel attempt to explain the puzzle of why art museums that are presumably accessible to all so often have an audience that is disproportionately composed of the "cultivated classes." They conclude that "the love of art," which is so often understood as a natural gift, is in fact shaped by socioeconomic status. Or, artistic competence-familiarity with the classificatory schemes of art and the ability to decipher its underlying symbolic codes-depends on family upbringing and education. Without the ability to decode the work displayed in museums, less educated audiences experience unease and reject museumgoing altogether. Sociological work on upper-middle- and upper-class museum philanthropists also typically emphasizes their connoisseurship. In her research comparing various types of museum funders, Victoria Alexander describes individual patrons, in contrast to government, foundation, and corporation patrons, as particularly motivated by a passion for art. "Traditional patrons are interested in the art itself," she writes. "They are connoisseurs and collectors who are interested in objects-or the status or monetary value that can be derived from objects" (Alexander 1996, 92). Similarly, in her research on patronage, Vera Zolberg (1981) argues that in the early years of fine art museums in the United States, aesthetic authority was in the hands of wealthy patrons rather than professionally trained staff. 


\section{The connoisseur's eye}

These and other studies cast museum patrons as sharing a deep appreciation for, and understanding of, culture. However, in her research on trustees on the boards of art museums and opera houses, Francie Ostrower (2002) challenges this characterization of the cultural philanthropist as connoisseur. She notes that though it is typical for trustees to have a general appreciation of art, they do not all share an identity as connoisseurs. For example, one trustee whom she interviewed said, "I don't know much about art. I'm no art historian. And my taste is only as refined as I know what I like when I see it" $(1999,47) .{ }^{3}$ While Ostrower rejects the idea that all cultural philanthropists are connoisseurs, she does not delve in depth into the distinct ways of valuing museums among the subset who are. In this chapter, I divide cultural philanthropists into two categories, cultural connoisseurs and cultural appreciators, and describe how their valuations of African American museums vary.

Connoisseurs have extensive knowledge about, passion for, and engagement with "legitimate" culture. As Herbert Gans (1999) in his classification of the "high culture" taste public notes, this is a group that includes both a "user-oriented" and "creator-oriented" segment, with the former including collectors, and the latter including artists and others employed in high culture fields. In contrast, appreciators correspond more closely, though not entirely, with Gans' “upper-middle culture.” Gans describes upper-middle culture as "the taste culture of the vast majority of America's upper-middle class, the professionals, executives and managers and their wives who attended the 'better' colleges and universities” (1999, 79-89).

Although well-educated, they are not trained as creators or critics, and like the user-oriented public of high culture, they are not creatororiented, but unlike the latter public they do not find high culture satisfying. They want culture and want to be cultured, but prefer a culture that is substantive, unconcerned with innovation in form, and uninterested in making issues of method and form a part of culture.

Although appreciators' participation in museum philanthropy is perhaps at odds with Gans' delineation of the purveyors of upper-middle culture not finding fulfillment in high culture, his description of this group as being lightly to moderately interested in, and engaged with, high culture does fit. For example, appreciators may display a few collectible works of art or historical objects in their homes and have an art book or two on their bookshelves. However, in contrast to connoisseurs, they have no or only a passing interest in building a museum quality collection or amassing an expansive library of art or history books.

Despite sharing the status of being philanthropists of African American museums, connoisseurs and appreciators vary in how they understand cultural value in the context of these institutions. The former emphasize cultural value more heavily, and their evaluations related to culture are more 
authoritative and refined. These differences are likely a function of the varying social conditions of their lifestyles. With extensive exposure to art and artifacts, along with regular and intimate interaction with other cultural experts, connoisseurs have a high level of cultural competence, which sensitizes them to the cultural dimensions of African American museums. Moreover, the conditions of their connoisseurship also provide them with the knowledge and confidence to make authoritative and substantive cultural judgments about these institutions. In the next several sections I describe in depth the distinctive cultural frame of connoisseurs. Following, I present a brief portrait of the cultural orientations of appreciators.

\section{Connoisseurs}

\section{Becoming supporters}

The "first involvement" narratives of connoisseurs, or the stories that they tell about why they became patrons of African American museums, generally lead back to culture. For example, a connoisseur who collects African American historical artifacts along with his wife says,

Well, we have always enjoyed going to museums, and when we heard that this particular collection [of privately owned African American artifacts] had been bought by the [museum], we thought that was interesting. So, we started attending whatever meetings they had, and that is how we got involved.

In cases like this, museum philanthropy offers an opportunity for connoisseurs to deepen their involvement with a pleasurable dimension of their lifestyle. A desire for others to have intimate encounters with art also motivates some connoisseurs to become patrons of black museums. "I know that we're really blessed," one collector says about his family.

I wake up every day and I get to live in a space where I can see the work. There's not a security guard. There's not someone standing over it. There's no barrier to the experience. My children get to grow up in a household with that. So, I'd love for other people to have that same kind of experience and approach with the arts.

For these connoisseurs, a love of culture motivates their support of black museums. For others, culture is also the reason for their philanthropy, but it is cultural expertise as much as cultural appreciation that motivates their involvement. A trustee who is a collector emphasizes how his cultural knowhow motivated him to serve on the board. "Having a chance to serve on a museum board was really important [to me]," he says. The museum not only "needs collectors' art" he explains, but also needs their "skills and 


\section{The connoisseur's eye}

knowledge." A member of the staff at a majority museum who serves as a trustee at a black museum describes how it is his knowledge about cultural organizations that makes him a good fit for the board. "I know why I was asked to be on [the board] and that's because of my nuts-and-bolts museum experience," he explains.

I've been here [the Centersville Museum] a good long time. For three quarters of that time I have been a curator, but I've also had senior administrative responsibilities. ... So, basically what I can bring to a board is real know-how about how a museum operates and runs.

This connoisseur sees himself as occupying an implicitly cultural seat on the board. In his view, he was asked to join the board because of his expertise about how museums work. Other connoisseurs also see themselves as being informally designated by staff and other trustees as the cultural experts on their boards. A collector of black historical artifacts comments that an invitation was extended to her to join her city's black museum board because of her "familiarity with local African American history."

While connoisseurs often describe how cultural interests and knowledge motivated them to become patrons of black museums, it is also not uncommon for them to note how individuals in their cultural network of colleagues, friends, and acquaintances first connected them with the museums that they support. For example, one trustee who has "always been interested in art" and "collects paintings of young artists who are up and coming" describes how he first became linked to his museum through a longstanding friendship. "The director of the museum was a classmate of mine [in college]. We graduated the same year," he says. "I visited the museum just because of my friendship with him. I was introduced to some of the collections ... and he would send me notices of exhibits that were coming to the museum." A collector who works in the field of history also recalls how he was asked to join a board because of a friendship with the museum's director. "Because of my work in African American history I have been very involved in museums," he explains. "I met Bethanne [the museum's director] and we had similar interests and became friends."

For one trustee who works as an artist outside of his job in management it was his interest in art, and ties to museum staffers, that put him on the path to black museum patronage. "I actually first got involved with the museum ... because I'm an artist on the side," he says.

I had some friends that ... worked at the Museum of African American Art, Ambertown. They told me about this [event] ... where they were bringing in a bunch of local artists. We ended up doing a live art competition. ... I thought it would be a good opportunity to give back... It was a really cool experience. I actually ended up winning the competition. ... It was a really deep dive into understanding the museum. 
In these instances, connoisseurs attribute their patronage as driven by cultural interests coupled with preexisting social ties to the museums. In a sense, it is as if they see culture as a necessary but insufficient factor to explain their patronage. Because of their cultural interests and knowledge, they have an alignment with African American museums. However, it is their relationship with a friend, acquaintance, or colleague that actually sparks their support. These ties act as cultural matchmakers, bringing together African American museums and connoisseurs who can offer them cultural resources. Without these relationships, it is possible that these connoisseurs would have never become matched with the particular museums that they now support. Relationships with staff, board members, or affiliates of other museums may have directed their philanthropy to those institutions. Or, if such a tie were absent, it is possible that some of these connoisseurs might not have added museum philanthropy to their repertoire of cultural activities at all.

\section{Aesthetic mobility}

Sensitivity to the cultural dimensions of black museums is evident not only in connoisseurs' narratives about how they first became patrons, but also in their concern with the legitimization of black history and culture. Connoisseurs are commonly sensitive to aesthetic hierarchies that organize cultural objects and producers along a scale of worthiness. As a result, they are often keenly aware of where cultural objects and producers associated with the African diaspora fall in these rankings. Of particular concern for some is what they see as the undervaluing of these objects and artists. A connoisseur describes how his original impetus to collect African American artifacts was related to failure in the cultural community to appreciate them. "I think I understood at the time how that history was undervalued and underrepresented. I wanted to somehow keep as many of those items alive as possible," he says. "I had no idea, in many cases, the real value. ... But, I just knew that they were valuable for my community." This sentiment is echoed by a supporter who says,

I think a lot of African American artists are overlooked and they meet, if not surpass, a lot of what is thought to be representative of other art canons. Once they get that exposure ... people are floored and wonder how did they miss the boat. It shows the disservice by the museum establishment and the art establishment in my opinion.

In the minds of some connoisseurs, what they view as the systematic devaluing of black cultural objects and black cultural producers is not due to the inherent quality of the former or the natural talent of the latter. Instead, it can be partly accounted for by the socially contingent process of valorization (Baumann 2007; Becker 1982; Benzecry 2014; Childress 2017; Dávila 2008, 2012; Fine 2004; Griswold and Wohl 2015; Lena 2012). Bourdieu 


\section{The connoisseur's eye}

(1993) contends that each field of cultural production, such as fine art, is organized as a system of positions. The positions of agents in each field are determined by their volumes of capital. Inherent to each field is not only a struggle among actors to accumulate capital and occupy dominant positions, but also a set of rules that determine the rules of competition. In the art world there is a struggle for symbolic capital or prestige. Certain "agents of consecration," such as museums, have the power to confer prestige upon artists and artworks.

In the minds of some connoisseurs, cultural producers and objects from the African diaspora are undervalued. However, given that cultural value is produced via proximity to legitimizing cultural institutions, these connoisseurs also often recognize that African American museums themselves can play a role in the production of symbolic capital for black culture (see Figure 4.1). A black connoisseur who recently gave two paintings to a black museum describes the donations within the frame of aesthetic mobility. "I remember early in our collecting we [he and his wife] were invited to this little dinner party," he shares.

It was maybe five couples and we had just started collecting. It was a dinner party that was celebrating John Lomar [a well-respected African

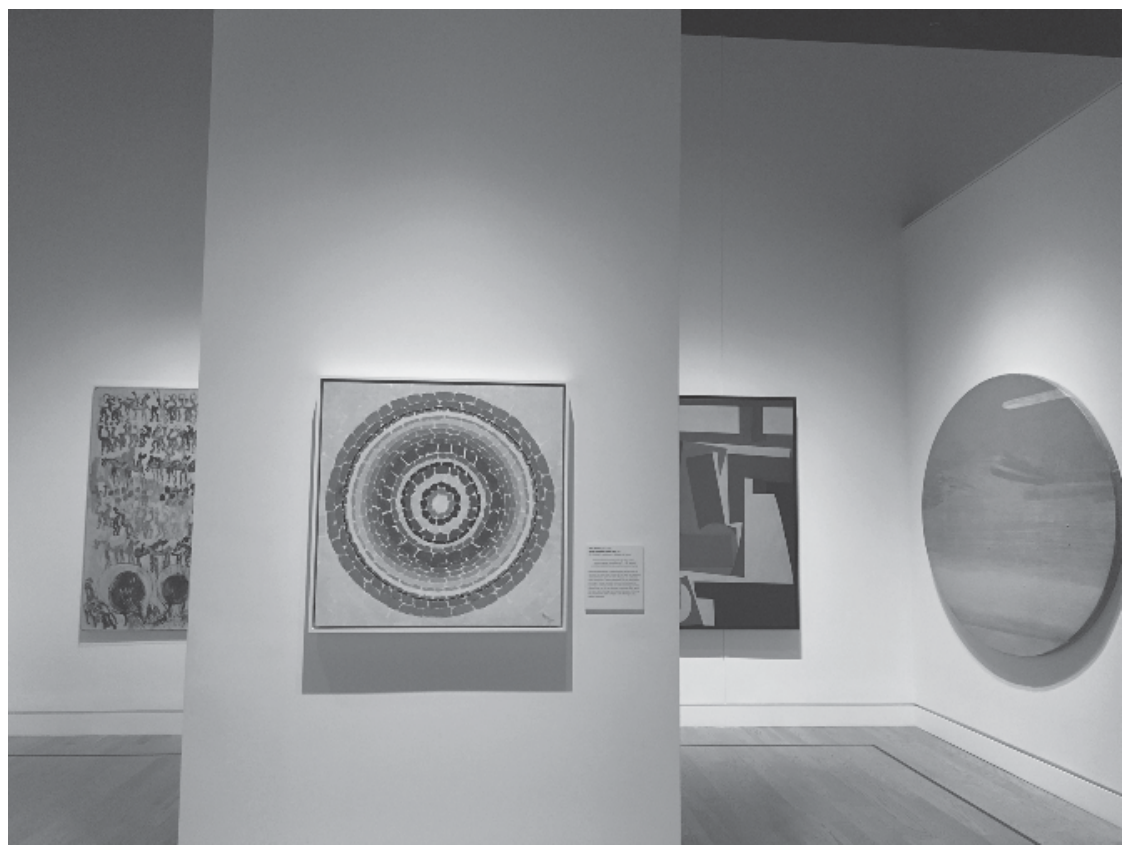

Figure 4.1 Culture galleries in the National Museum of African American History and Culture. 
American artist].... We sat down at the dinner party and had a great conversation. But, I'll never forget his statement saying, "If you're concerned about what's represented in museums, and you want to see work that represents you, then you should give to the museum." $\mathrm{He}$ made that statement in a very clear and kind of poetic and direct way. Museums in effect are made up of collections of collections. If you're not seeing the artists or the work represented there, then you as a collector ... have an opportunity to proactively do something about it. So I remembered that. [I realized], yes, there's a more active role that I can take. ... So, we've given work before. ... But, this gift to the Citrine Museum of Black History and Culture was a pretty big statement. We wanted to give relatively large pieces, and we felt that it was important that the artist have this platform. He wasn't in a lot of major museums, but we felt that he should be.

Connoisseurs are often sensitive to not only the role of African American museums in increasing the symbolic value of black cultural objects, but also their role in bringing up the pieces' economic value. As with the symbolic value of these objects, there is often a sense among connoisseurs that their economic value is underestimated. Or, it is not uncommon for connoisseurs to believe that the objects should command more money in the market. "Even as popular as black art has become, there is still a disparity between the prices of the best black artists and even some mediocre white artists," one collector comments. "There's still a gap. Mediocre might be strong, but just some so-so white artist-they are still commanding higher prices than the best black artists." ${ }^{4}$ While some connoisseurs see black cultural objects as short-changed in the market, they also recognize that just as cultural value is socially determined, so is economic value. They note that African American museums can influence the market for black cultural objects. "A museum show or being bought for a museum collection, all of the above help an artist's market," one collector explains. A work's exhibition or acquisition by an African American museum not only adds to its economic value, but also helps to enhance the general "bankability of an artist," another patron notes. His comments are consistent with theory positing that by driving up the symbolic value of cultural objects, intermediaries such as museums also play an important role in determining their prices (Banks 2018, 2019b; Khaire 2017; Velthuis 2005).

While some connoisseurs are concerned with increasing the worth of black culture, their interest in value augmentation does not extend to all objects and producers. They hold fast to a belief in cultural hierarchy. In their view, race-related barriers that contribute to the underrecognition of black culture should be eliminated. Yet, aesthetic standards that sort producers and objects into the worthy and unworthy should remain. Thus, while connoisseurs often recognize that reputation is shaped by social factors, they do not believe that it is entirely socially determined. Instead, many believe 


\section{The connoisseur's eye}

that fundamentally some works and artists are better than others and that African American museums should play a role in sorting the wheat from the chaff. Although terms such as "African American art" and "black culture" group together cultural objects that share a connection to the African diaspora, connoisseurs often believe that qualitative distinctions should be made within these categories. To them, not all black culture is of equal quality. As museum supporters with cultural expertise, they see themselves as in an ideal position to help clarify these distinctions. As one connoisseur insisted, African American museums should not be "a gathering place" for all black culture. Rather, they should be a place for "the best" of that culture. Just as majority museums have played a role in creating aesthetic hierarchies within "mainstream" culture, connoisseurs with this perspective believe that African American museums should reinforce aesthetic boundaries within black culture.

In his research on museums, DiMaggio (1982a, 1982b) argues that distinctions between "high" and "popular" culture in the United States were not solidified until "cultural capitalists" in the 19th century established museums and other cultural institutions. Before this era, popular culture and high culture often mingled within the same spaces, and the conceptual distinction between them was fluid. With the establishment of cultural institutions, such as museums, a structural boundary was created by placing only a select group of objects within their walls. Those left on the outside were then cast aside as objects that intrinsically lacked merit and were unworthy of serious attention or care. Some connoisseurs who sit on acquisitions committees see it is as their job to ensure that unworthy objects do not find their way into collections. "[Black] museums should not be the dumping ground for African American art," one comments. "All museums have standards. Why should we be any different?"

When I ask a supporter with expertise in cultural institutions what he contributes to the board, he describes his role in helping the museum to organize their approach to acquisitions in light of the opening of their new building. He offers his view about the most appropriate types of acquisitions for the museum. "Any organization that is a collecting organization needs a very sound policy," he says. "Otherwise, anything that gets offered to it becomes a dilemma, 'Oh, do we accept this, do we not?'”

Any museum has to understand that anything it accepts, even by gift, costs money, because there's space that's required to store it, and systems that are required to store it safely. There's staff time that's involved, and everything like that. So, collections are a very serious obligation and have to be thought through with great clarity. It will not be my role to establish the policy, but it will be my role to put together the sort of structure of how a plan can be organized, and then have the board and staff collaborate in saying, "This is what we want to be. These are the kinds of things we want to collect. Do we want to collect archival documents? Do 
we want to collect works of art? Do we want to collect artifacts of historic interest?" ... I think that's step one-to define collecting. ... Personally, I believe in the value of archival materials. If archival materials are available and are easy to store, and they may be pieces of paper, they may be photographs and things like that, I think those are very worth having. I think when you get into objects you get into a very different set of situations. Somebody may have something that's very small, an inch or two or three inches. Or, they may have a piano. Well, what are you going to do with a piano? Are you prepared? Do you have the staff to move it, the space to store it, the reason to show it?

A trustee who recently began a course of study in art history also describes how cultural knowledge allows her to offer insight on appropriate acquisitions for her museum. "I am studying art history so ... it means that I can help [with acquisitions]," she explains.

I can make more informed decisions and more informed recommendations to the acquisitions committee. I'm doing this [training in art history] for my own edification, but I think that there's a benefit to the [museum]. I hope Janet [the museum director] would say that [my art history background] helps her to have an acquisitions committee chair who knows a little bit about what she and her staff are talking about and what they're trying to do-[someone] who understands their purchase recommendations, for example, or exhibition recommendations. I come to it with just a little bit of knowledge, a little bit of understanding, which I think helps them. ... There was a work that the museum staff suggested that we consider. One of our committee members expressed the ultimate insult- "My six-year-old could do that." In fact, his six-year-old couldn't do it. The work ... was priced appropriately. It was done by someone who had a good reputation. I try to help people understand that maybe your six-year-old could have done it, but he didn't. This artist did. There is a meaning to this that might not be immediately evident. I try to help explain who the artist is. If she [the director] thinks it's important for us to have, I try to give that kind of support to her.

A collector of historical artifacts also describes his contributions to the board in relationship to identifying appropriate objects for acquisition. "Well, in many ways I am a historian, so I can talk about the history because a lot of people [other trustees] come from business. They like this or they like that, but they don't think in a historically correct way," he says. On the acquisitions committee he uses his knowledge about history, and collecting more broadly, to inform the decision-making process concerning which objects to acquire. "A lot of people have things that are very valuable to them, but if it doesn't fit our collections ... we can't really use it," he explains. 
Someone had a book about their travels to Ghana in the 1950s and "60s. I said, "It's a great book, but it's not relevant to what we deal with." ... Somebody wanted to give us a piano. We can't use a piano.... You can't, because once you take it then you have problems with space. ... If we take a painting I ask, "Can we preserve that? Can we maintain it?" ... So, there are things that we can use and can't use.

Some connoisseurs view the issue of black museums acquiring appropriate objects as so important that they recruit other patrons who have similar taste and knowledge as themselves. One connoisseur explained how her interest in having a particular collector join her museum board was to have him set a high bar for acquisitions. She commented that the aesthetic standards of board members can be quite varied and it is frustrating when some want the museum to acquire work by "their best friend's cousin" or others who do not make the cut for "museum quality."

\section{Collections care and display}

If, as connoisseurs believe, African American museums should house a subset of higher quality black cultural objects, then it follows that the objects should be treated in a way that befits their elevated status. Connoisseurs see black museums as stewards of black art and artifacts, and it is important that museums treat pieces with the special care that they deserve. In connoisseurs' eyes, part of the appropriate treatment of these objects is that they are seen. In his research on the production of culture, Howard Becker (1982) argues that appreciation is one step in the production of culture. Not until an audience has consumed the work is its creation complete. Some collectors bring up frequency of display as one factor that they take into consideration when deciding to loan or donate work. "What I wouldn't want to do is give [a] work to a place that couldn't accommodate it, couldn't share it," one collector says. A collector of contemporary art explains that he will not give to a museum where he suspects that the work will be banished to "backroom storage" and "not see the light of day." On the one hand, these connoisseurs believe that objects owned by museums should be seen. On the other hand, they emphasize that certain objects, such as works on paper, should not be seen too much. Excessive light may damage works in these more fragile media.

This last point is related to the broader issue of the conservation of works at African American museums. Before the beginning of the black museum movement in the 1960s, the primary repositories of African American art in the United States were Historically Black Colleges and Universities. Schools such as Howard University, Fisk University, and North Carolina Central University hold significant collections of this work. In 2000, a traveling exhibition, To Conserve a Legacy: American Art from Historically Black Colleges and Universities, highlighted a major cross-campus effort to 
preserve the collections of several schools. Some connoisseurs knew of this effort and specifically named it as a worthy undertaking.

More broadly, collectors often insist that they will donate or lend work only if they are confident that the receiving museums have excellent conservation and care practices. When I ask one connoisseur if he plans to make gifts from his collection to the museum where he is a trustee, he comments, "It will go, but our general guideline is, 'Can they use them? Do they want them? Can they take care of them?' " Preservation, along with other factors, will be considered when a patron who works in the cultural sector makes the final decision to donate art to the museum where she is a trustee. "I think I have to be very cognizant of whether they have the capacity to show it, preserve it, and maintain it," she says.

Because of the cost of caring for art, one connoisseur insists that when patrons donate art to black museums, they should also donate money for its upkeep. "Most people don't realize what the institution takes on [with donations]," he explains.

There's a liability that comes with it, because they have to be prepared to store it. They have to prepare it for ... displaying to the standard of the museum. They can't just take it in a frame like [the donor] has it. Maybe if they [the donor] had it properly framed, it might be fine. But, some works have to be cleaned. They [museums] have to put it into their inventory. These things have costs attached to them and most people are just not aware of that.

In a survey distributed to major collectors of African American art to assess potential loans and gifts to the NMAAHC, collections care was a central concern for respondents. In one question, respondents were asked what factors-including "collections management policy," "collections care/conservation policy," "security," and "exhibitions space/gallery conditions"would determine the availability of works in their collections for loan. Most respondents chose at least three of these considerations, and several chose all four. When asked to comment about loan policies, respondents also referred to collections care, making statements such as, "We loan to reputable museums and galleries whose professional histories show responsible exhibition policies and practices" (Completed Questionnaires 2003).

\section{Patronage}

Along with being attentive to the care and display of objects in museums, connoisseurs typically place significant value on the experience of viewing objects. It is often highly memorable and meaningful to them. When asked about their favorite exhibitions, connoisseurs often enthusiastically name specific shows and discuss particular artists, artworks, or artifacts. Any hesitation in talking about favorite exhibitions is typically linked to time spent 


\section{The connoisseur's eye}

thinking to shorten the list-for example, "There are so many, it's hard to narrow it down," or "How much time do we have?" In describing especially impactful exhibitions connoisseurs often comment in detail about the works. For example, one collector vividly describes his response to a photography exhibition. "There was black-and-white photography," he says.

It can be immensely revealing because your eye is looking at all of these different textures. When you see these different hues of gray, your eyes are focused in on different details, which can tell a different story and set a different mood simply because there is that lack of color.

With a keen interest in culture, connoisseurs are typically especially appreciative of the distinct opportunities for cultural exposure that are available to higher level patrons. In their research on museum patronage, Judith Huggins Balfe and Thomas A. Cassilly (1993) describe friends' programs at museums in the United States. These special patron programs emerged in the 1920s to help support acquisitions. For a moderate donation, members of friends' groups enjoy a special set of privileges at the museum. Friends groups are common at larger African American museums. These groups are part of tiered membership programs that offer more benefits for higher levels of membership. At the highest levels, which vary from museum to museum and from gifts that range from around $\$ 1,000$ to $\$ 25,000$, supporters are given special access to museum staff, artists, art and artifacts, and museum buildings themselves. Benefits such as meeting the director and artists, attending VIP events, and going on cultural tours with museum staff are not uncommon. For example, for a donation of $\$ 1,500$ patrons can join the Studio Society at the Studio Museum in Harlem. In recent years, the group has participated in events such as a preview of work by Lynette Yiadom-Boakye-the first woman of African descent to make the shortlist for the Turner Prize-at the Jack Shainman Gallery. Thelma Golden, the museum's director and chief curator, was present at the event, along with Yiadom-Boakye. The group has also met with noted artists such as Trenton Doyle Hancock, Stanley Whitney, and McArthur Binion.

A connoisseur fondly recalls experiences with her museum's friends' group. "We have something called the Friends of Art group," she says.

This is a group of people who pay $\$ 1,250$ every year to go on a nice art tour-a tour of, say, artist studios, museums and galleries.... [Recently], we went to the Contemporary Art Museum, we went to Jennifer Wilmer's studio, and we went to the Blue City Art Museum.... We saw an exhibit of African art and artifacts there.

In some cases, collectors' first encounters with artists whose work is in their collections is via African American museums. For example, Bernard Lumpkin and his partner Carmine Boccuzzi are patrons of the Studio 
Museum in Harlem. They collect contemporary art from the African diaspora and own works such as Clifford Owens' diptych "Anthology (Nsenga Knight)" (2011). Commenting on the work, Lumpkin notes how he first met the artist through the museum. "Collecting is about building relationships with curators, other collectors, and educators, but first and foremost with artists," he comments. "I met Cliff early on through the Studio Museum and through performances, primarily" (Rosenberg 2016).

Along with meeting artists via their ties to museums, connoisseurs often assign significant value to opportunities to get special access to see them at work. Studio visits allow patrons to meet artists and to view various works at different stages of production. "When we went to John Tim's studio, we saw works that he was just starting and others that were almost complete," one collector recalled. This collector had seen the artist's paintings in an institutional context but not actually met the artist or seen his work in an unfinished state.

It is not only nurturing ties with artists that connoisseurs often cite as a meaningful benefit of museum patronage, but also building ties with museum staff. Philanthropic activities such as trusteeship, membership in friends' groups, and lending objects bring supporters into close contact with museum staff. As many connoisseurs note, these relationships can yield personal benefits. Or, to put it in more formal terms, connoisseurs often view relationships with museum staff as a form of social capital. "Years ago, we actually donated a work to be in an exhibition at the Pine City Black Museum, and Susan [the director] was awesome," a collector recalls.

The exhibition was Jan Briggs, so the piece that we have in our living room was actually in the exhibition and in the catalog. We got a chance to fly in and spend the weekend when that show launched with Jan and Susan.

A collector of historical artifacts and fine art describes how his longstanding relationships with curators means that he is more likely than other collectors to be invited to lend works for exhibitions. "They know what I have," he explains. "One of the curator's biggest problems is knowing where stuff is." Other collectors explain how relationships with museum staff put them in a position to get advice that is helpful for further developing their collections. For example, a curator from the museum that one couple supports visited their home to see if any artifacts from their collection might be suitable for an upcoming exhibition. This was valuable to them because it meant that they had a professional expert assess their collection.

Connoisseurs also often laud the efforts of black museums to encourage collecting through special talks and programs. For example, for several decades the Studio Museum in Harlem has held programs on art collecting, like the 2011 panel "The Fine Art of Collecting" with the artist Dewit Petros 


\section{The connoisseur's eye}

and the collectors Kenneth Montague and Alvin Hall. Similarly, when the National Black Fine Arts Show (NBFAS) was still running, the Museum of Contemporary African Diasporan Arts partnered with the art fair on an education series. The series was designed to provide collectors with knowledge and insight about how the art world operates. One collector describes how he gained insight on the ins and outs of collecting at a similar event. "I participated in the Afro-Diasporan Cultural Center's collector's series," he says.

There were four classes once a month ... that kind of ran the gamut from how to care for your art to how to buy in the auction market.... There were printers there. There were estate planners. Every facet of the art market was represented and discussed.

Connoisseurs also value the role of museums in bringing together collectors. They meet one another in friends' groups and foster ties through activities such as visiting the homes of other collectors. Although it was common for connoisseurs to highlight meeting other collectors as a benefit of their patronage, black connoisseurs more often specifically described the opportunity to connect with African American collectors as an asset. There is a long history of African Americans collecting fine art (Banks 2017, 2019a). Yet, "you don't hear a lot about us [blacks] as art collectors," a patron notes. One black connoisseur talks fondly about how by getting involved with her local African American museum she has not only met other African Americans who collect, but also learned more about the tradition of art collecting art among African Americans. The camaraderie that she finds among other black museum patrons who are also collectors is particularly welcome given what she describes as a "lack of diversity" in the art world.

While on the one hand connoisseurs are attuned to the benefits that African American museums can provide for patrons, they are also sensitive to the benefits that patrons offer to museums. In their view, the cultural expertise that they offer to African American museums is critical. This is illustrated by the comments of one connoisseur when I asked her about the type of person whom she would like to succeed her on the board. "It should be someone with an appreciation and understanding of art. I will probably reach out to some of the collectors that I know," she says. The value that some connoisseurs attach to patrons with cultural expertise is also illustrated by the comments of a respondent to the NMAAHC collectors' survey. In a letter one collector attached to her completed survey, she not only provided more context about her collection and invited the study's research consultant to see it in person, but she also raised concerns about the direction that the museum could potentially take. "I was concerned that I did not immediately recognize any major collectors or art historians on your commission in conducting this study," she wrote. "I feel that their direct participation would be an invaluable resource. Far too often, collectors are not ask[ed] to 
participate until there is a need to use their collections!" From her vantage point, the success of the museum would depend on substantive involvement from experts in fine art (Completed Questionnaires 2003).

\section{Staff}

Connoisseurs also see staff as necessary for creating great cultural institutions. In his research on the role of museums in solidifying the boundary between high and popular culture, DiMaggio (1991) argues that central to this differentiation was a shift in the structure of authority in museums. When museums in the United States were first founded, curatorial decisions were often made by laymen who had not received specific or extensive training in the arts. While these amateurs might have had a passion for art and culture, professional expertise was lacking. However, over time a professionalized cadre of staff began to take up curatorial roles. This shift from "the preprofessional era" to the "professional era" was brought about as the field of art history codified knowledge and practices in the discipline (Zolberg 1981). With each passing decade, the position of curator commanded more museal authority and demanded upholding higher standards. As the position of curator gained legitimacy, so did the power of museums as legitimizing organizations for culture. Connoisseurs are often especially sensitive of the importance of staff for upholding the standards of African American museums as they shape canons of black culture.

Typically, the connoisseurs I interviewed expressed respect for staff making curatorial decisions. This is the case for one patron who commented, "The curators do an amazing job putting together wonderful exhibitions. I'm really proud of our exhibitions because ... they are very well thought out." It is a museum director's ties to highly respected artists that earn praise from another connoisseur, who says, "Pamela Jones [the director] is just fabulous. She studied under Johnson Wells [a well-respected African American artist] and was personal friends with him and manages his foundation." An artist also doles out praise for a museum director, emphasizing that the influential position of the museum that she leads is "largely because of the work that she has done." He notes that her efforts "have basically transformed it [the museum] into a ground to vet only the best and the brightest." Similarly, it is because of his respect for curatorial staff that one collector does not "interfere with the selection process" when he lends art and artifacts for exhibitions at the museum where he is a trustee. "I believe that the curators are artists and that [selecting content and deciding how it will be presented] is their job. Period," he says.

When I had [the show from my collection] I was guest curator. ... I had in mind how I expected it to be mounted. Thank God, I didn't [interfere] because what he [the curator] did ... was so totally different from what I had in mind. And, about 500 percent better. ... That's his magic. 
This collector is confident about his own curatorial instincts, but he respects the professional expertise of curators even more. While I rarely encountered connoisseurs who were highly critical of the specific decisions of particular curatorial staff, the fact that they have strong opinions about such matters offers evidence that they do monitor curators' work. Connoisseurs who strongly opposed certain curatorial decisions could curb their support. As one collector contemplated such a scenario, she paused and then remarked,

I don't like all of the shows that we have here, but that is probably a good thing. Art should provoke a strong reaction. At the same time, if I found myself constantly disappointed, then it wouldn't make sense to continue my support.

Architects are another category of cultural professionals that some connoisseurs make judgments about. In cases where museums are being established or remodeled, architects are selected. Some connoisseurs see this as an important hiring decision because not only does the esteem of the architectural team rub off onto the museum but also their designs are subject to cultural assessment. Certain museums, such as the Kentucky Center for African American Heritage, the Birmingham Civil Rights Institute, and the Harvey B. Gantt Center for African-American Arts and Culture, were designed by well-respected architects. Some of the buildings, such as the NMAAHC, have also been lauded for their innovative designs. Comments such as, "Let's not forget that the Black Museum of Greenston is also notable for its architect" and "The Citrine Museum of Black History and Culture building is a masterpiece itself" illustrate some connoisseurs' attention to architects.

\section{Museum field}

The sharp cultural lens through which connoisseurs view black museums is also evident in their attention to the positioning of black museums vis-à-vis one another and majority museums. Their field-level view of the position of African American museums is often understood in relationship to competition and collaboration. From the competitive perspective, it is useful to turn once again to Bourdieu's (1993) theory of cultural production. In this theory, it is not just cultural producers and cultural objects that compete for status, but also museums themselves. Museums that have accumulated the most symbolic capital, or are considered first-rate or great museums, are the winners in this competition (Pachucki 2012). It is this high status that gives museums the power to legitimize cultural producers and objects. This means that museums that have less legitimizing authority will be less effective in granting symbolic capital to cultural producers and objects. Connoisseurs are often sensitive to competition between African American museums to 
gain recognition within this particular field, as well as efforts of African American museums to gain status within the field of museums at large. They are aware that if African American museums have little respect, then their ability to confer status on black art and artifacts is limited. But connoisseurs do not only view museum fields as competitive in nature. They also envision the African American museum field, and broader museum field, as institutions that exist in a network of mutual interdependence. With this interdependence African American museums need to cooperate with one another as well as with majority museums to survive and thrive.

\section{African American museums}

Just as connoisseurs emphasize distinctions among black artists and objects, they are also sensitive to distinctions among black museums. Or, in the words of one connoisseur, they are attentive to the fact that "not all black museums are the same." When deciding where they will give their support, they sometimes place institutions in a hierarchy based on which institution will offer the most benefits. With the establishment of the NMAAHC, the issue of competition among African American museums reached a climax. The NMAAHC significantly outpaces other African American museums in areas such as public visibility and budget. Some staff at other African American museums have expressed apprehension about losing gifts to the NMAAHC. While Charmaine Jackson, executive director of the California African American Museum, is "thrilled" that the NMAAHC was established she notes that "there's apprehension and fear amongst many that people won't support all the other black museums that have existed for so long ..." (Trescott and Freedom du Lac 2012). Shirley Burke, who owned a violin passed down from an enslaved relative, decided to make her gift to the NMAAHC partly because of its behemoth status. "I wanted to put it in a place where more people would have access to it, and more people will go to D.C.," she explained (McGlone 2016). One collector I interviewed also noted that the NMAAHC will be attractive to donors like himself because "they will create national exposure."

In the eyes of some connoisseurs, the best strategy for African American museums to manage competition with one another is to develop specialties within black culture and history. According to one trustee, when his museum was founded, it distinguished itself from other black museums by focusing on history, rather than art, and on the local community. Today, he is confident that this "local focus" properly distinguishes it from "the new national museum" (NMAAHC). Other supporters emphasize how African American museums should collaborate with one another so that they all benefit from the particular strengths in the field as a whole. One connoisseur pointed to the NMAAHC's inaugural exhibition, Let Your Motto Be Resistance: African American Portraits, as a model for collaboration among black museums. After showing in Washington, DC, in the 
NMAAHC's temporary galleries, the exhibition traveled to several museums across the nation, including black museums such as the California African American Museum, the Birmingham Civil Rights Institute, the DuSable Museum of African American History, and the National Underground Railroad Freedom Center.

\section{Majority museums}

Just as connoisseurs are attentive to the position of African American museums vis-à-vis one another, they are also heedful of the museums' position relative to majority museums In particular, some connoisseurs are sensitive to the invisibility and lower status of African American museums relative to their majority counterparts. One trustee's comments about where she hopes to see her museum in ten years highlights how large majority museums in her city are at the top of the museum hierarchy. "I would love the Gallery of the African Diaspora to be considered a must-see museum in Azure City. I want people to think of the Gallery of the African Diaspora the same way they think of the Azure City Art Museum," she says. Similarly, a collector acknowledges that while tourists to his city view a visit to one of the big majority museums as obligatory, they do not see the black museum where he is a board member as a must-see stop.

I was in a meeting a couple weeks ago with the guy who's the director of the Violet City History Museum. ... I was trying to talk about how to get more people to come here [the black museum], and he says that a lot of people who come to his museum feel obligated to go there. They come to Violet City, and they feel that, "Well, we at least need to go through the Violet City History Museum." It's true for people who are educated and uneducated, it's "Wanna go to see the Violet City History Museum?”

Aware of the typically higher status of majority museums, some connoisseurs see an advantage to supporting black history and culture initiatives at them. Describing the criteria that she considers when supporting a museum, one connoisseur comments, "It doesn't necessarily have to be an African American museum, but I would want to know that the institution had an agenda to promote the works of African Americans or people of color.”

One of the things that was interesting at the American Art Museum was that they exhibited Patrick Johnson [an African American artist] during the grand opening of their big new space. It was a big deal for them to feature an African American artist who is not as well-known as like a Romare Bearden. His work is very highly respected, but there's not a lot of it out there. There hadn't been an exhibit with his work of 
that stature before, so for them to do something like that was pretty significant. The institution is saying, "We think this is important. ..." It was packed. There were tons of people there in part because it was the American Art Museum. Whatever they say, people are going to listen. So, I would like for whatever place [that I support] to be a place that is doing something along that same line, even if they haven't done it before-promoting people of color and the importance of their work. That would be really important to me.

Although this collector gives to both majority and black museums, she recognizes that one advantage of supporting the former is that their typically greater symbolic capital can confer an especially high level of status on, and exposure for, African American artists. Along with status variations, connoisseurs are often acutely aware of differences in the material resources between African American and majority museums. For example, a recent study by the DeVos Institute of Arts Management $(2015,2)$ showed that the 20 largest black and Latinx arts organizations had a median budget size that was significantly smaller than that of the biggest majority arts organizations. At the museum where one connoisseur is a trustee, fewer economic resources mean that its building is smaller than a nearby majority museum that is beginning to collect more work by black artists. "It [the majority museum] is a magnificent museum," she says. They have the space "to have a whole room dedicated to a single piece." In contrast, the museum where she is a trustee is "much smaller." "We are trying to display as much of it [the collection] as we possibly can, but there's only so much space," she laments. Also, unlike her museum that has a smaller collection and narrower focus, the majority museum can place work by black artists into a broader art historical narrative. "We don't have the breadth of work to do that," she says ruefully.

Like many connoisseurs, one collector reflects on how, because of the greater resources of the larger majority museums in his city and their growing interest in black artists, the museum where he is a board member faces growing competition:

It's tough competition for the little museums like the Black Museum of Leafston because they can't compete with the Museum of Fine Arts in terms of collecting - at least in terms of collecting art. It's not going to happen. And now the Contemporary Art Museum is collecting as well. Historically, they had not collected. They just started a few years ago, and that's going to be tough competition for any black art museum because they've got the resources that smaller black art museums do not.

Concern about limited resources at black museums can sometimes lead collectors to give more generously to majority museums than to black museums. Paul Jones, who passed away in 2010, was a major collector of African American art. Jones's biographers describe how his understanding 
of the resources available at black and majority museums factored into where he donated his collection (Andersen and Thomas 2009, 13).

His wish had been to house his collection at a historically Black Institution, but he found that these institutions did not have the resources to preserve and support it. Paul Jones's vision then-and now-was that his collection would be preserved as a whole, used as a teaching and research collection that would transform the understanding of American art to include African American art. He also wanted the collection project to be developed in collaboration with historically Black colleges and universities. Thus, in 2001 Paul Jones donated significant works from his collection to the University of Delaware, which established a collaborative arrangement with Spelman College.

A black history buff who plans to donate a significant portion of his collection observes that the general resource differential between African American and majority museums can affect the ability of the former to adequately care for artifacts. This is part of the calculus shaping his decision about where he will make his donation. He ticks off a list of black museums and notes, "For the most part, I probably won't give to [them] because they don't have the resources to use them and to maintain them," he says. Majority museums with more resources though are still in the running.

While connoisseurs who support both African American and majority museums may rationalize gifts to the latter based on their typically greater symbolic and material resources, some also rationalize supporting majority museums because black history and culture are less common at these institutions. One collector describes how it was the lack of African American artifacts at a majority history museum that compelled him to donate there. He reasoned that the objects would have greater visibility there:

PATRICIA: So why did you decide to give your collection to that institution? STEVEN: I had no intention of giving it [part of his collection] to that institution or any institution right now. I intended [to give] later, maybe ten years from now. ... But, I was approached by the person who was organizing the museum [the majority institution]. He was telling me ... that the museum would tell the story of blacks and it just resonated with me. ... Had the African American Museum [NMAAHC] project been farther along ... I would have sold it to that institution. But, I gave it to this institution because I thought it was the right time, the right place, and it had the right backing.

PATRICIA: Would you rather it be associated with the African American museum project?

STEVEN: I think as a result of it being the centerpiece of this museum it is going to have more visibility than had it been a piece of an African American museum. 
For another collector who has donated and loaned works to both African American and majority museums, it was partly the latter's lack of work by African American artists that spurred his gift. The works were deemed a good fit for the museum because they helped to diversify its collection. "Giving to the Simpson Art Gallery to fill in that gap was important," he explains. "They said, "We have a brilliant collection. But, we have these holes.' Knowing that I can actually help that has been something that is really important to me." In these cases, patrons selected majority museums as destinations for their gifts partly because of an awareness of the significance of racially integrating the collections. They see giving to majority museums that are still at the center of the cultural world as a vehicle to, as one supporter put it, "remake the mainstream."

With an acute sensitivity to the growing competition that black museums face from majority museums, some connoisseurs offer solutions for managing the competition. To them the path for black museums to gain recognition relative to majority museums is to accumulate status markers that designate legitimacy in the broader museum field. This includes forms of recognition such as Smithsonian affiliation and certification from the American Alliance of Museums. In this vein, one patron remarks,

I'm really proud to say that ... we are now officially an affiliate of the Smithsonian. So, that's fantastic. It puts us in line for a lot of grants and a lot of things that we wouldn't normally have been in line for without that affiliation.

Other connoisseurs offer partnerships between majority and African American museums as a strategy to manage competition. This approach views both types of institutions as having distinct strengths that can benefit one another.

One supporter praises the relationship that a black museum in his city has with the largest majority museum. "Do you know about the connection between the Black Museum of Leafston and the Museum of Fine Art, Leafston?" he asks me. "I think that that's an important connection. ... I think if mainstream museums can develop those kinds of relationships with black museums, it's a very good thing for both museums." A trustee who works in the museum field also celebrates the partnership between the largest majority and African American museums in his city:

The African American Museum of Centersville is partnered with the Centersville ... That opens up opportunities for free professional consultation, and it also warms up the relationship for collaboration. The Centersville thinks about the black history museum, and they think about the Centersville. ... There can be a symbiotic relationship in the best sense of the word. 


\section{The connoisseur's eye}

It was when a large majority museum was undergoing renovations and turned to its neighboring black museum for a collaboration that one trustee became especially enthusiastic about the potential for black museummajority museum partnerships in her city.

I would have to say that our relationship with the Azure City Art Museum is excellent. While they were going through renovations we did an exhibition that was in collaboration with [them]. We took some of their ... works by artists from the [African] Diaspora and we had an exhibition together. I'm proud to say that I truly believe that because of that exhibition we brought to light what they already had [by black artists]. [They] were excited to see how much response there was for that work and ... it gave them inspiration to have more of that work in their doors. ... So, I see it really as a partnership and perhaps we might be influencing them.

With growing attention to black history and culture by majority museums, some connoisseurs see collaboration as a solution to help ensure that black museums remain relevant. However, other connoisseurs underplay the threat of majority museums. While they may agree that African American museums generally fall short of majority museums in terms of material resources and general prestige, they stress that black museums rank higher when taking other criteria into consideration.

With the formation of the Association of African American Museums (AAAM) in 1978, the field of African American museums became even more professionalized. As with all forms of professionalization, this helped to legitimize the field. Some patrons point to the AAAM and their museum's affiliation with it as evidence that black museums are the standard bearers of black culture in their communities. As one patron insisted, the true experts on African American history in her city "are involved with AAAM" and work at the local black museum. Other connoisseurs describe how African American museums are a cut above majority museums for reasons such as their comprehensive focus on black art and history. "These other [majority] museums ... can also tell the story, but they may tell it in a different way. ... We're gonna tell it in a way that is multifaceted [and] global," a trustee reflects. She places weight on the fact that unlike the majority fine art and history museums in town that are increasingly mounting exhibitions related to African Americans, the black museum that she supports focuses on the totality of the black experience by highlighting "art, history, and culture" instead of just "one dimension of black life-meaning the art or history."

When taking into consideration self-determination, some black connoisseurs also rate African American museums more highly than their majority counterparts. These connoisseurs emphasize that a distinct value of African American museums is that blacks are often in leadership roles. While majority museums may increasingly focus on black culture, these 
connoisseurs note that the decisions made about what black culture is featured, and how it is interpreted, are often made by white curators, directors, and others in leadership positions. "The thing about an institution that is consistently and uniquely of, and for, the black community is that there's an opportunity for African Americans to own the story," a black connoisseur explains. Similarly, a black collector who has been purchasing work by black artists for the past six decades also highlights how black museums are exceptional because they are places where "we are telling own story."

[Black museums] were here in the 1960s. This is when the black museum movement got started. It partly start[ed] because mainstream museums ... weren't focusing on black art that much. ... [Black museums need to exist] because we need to define ourselves. Let me tell you, it's like everything else, if we don't define ourselves, then our history is not told. We have to tell our own story. They [whites] will find some things that are significant, but they will miss a lot. Only we can tell our story. ... Black museums are very, very necessary for telling our own story and being able to identify our own artists to look up to. We shouldn't wait for the New York Times to say, "This is a great artist." ... At black museums, we have to have the ability to choose our art, to exhibit our art, to determine what art we think is great art.... We need to have that ability to choose what is best for us and tell them [whites] what we think is best.

A younger black collector also describes the value of African Americans documenting "our story" at black museums:

Institutions in the black community have sustained us and will sustain us. If we don't tell our stories via museums, or we don't make sure that we educate one another via HBCUs ... then we leave other communities to document our story, and I don't think that we should do that. We should make sure that our story is told how we want it to be told, and I think the only way to do that is to invest in black institutions.... I think that you have to take some of your dollars and make sure that they are supporting people and issues that you are concerned about.

Some black connoisseurs specifically see black museums as in a unique position to interpret black history and culture because of black staff. "When I listen to Imani talk about black history, it comes from her perspective, a black woman's perspective, which I think is so important," a collector says about the director of the museum where he is a trustee.

I think that there are parts of that history that we might not get as fully in non-black museums. ... There's a curator of contemporary art at the Museum of Fine Art, Leafston. From time to time he's tried to be inclusive, 


\section{The connoisseur's eye}

but not all of the time. I think that he is not as quick to tell the story of certain artists or art traditions as someone like Imani in a museum of African American history ... because he comes at it from a different perspective.

These comments have parallels with the historian and curator Fath Ruffins' scholarship elaborating how rather than present purely objective accounts of the past, museums present subjective interpretations of what has been. "All interpretations contain some validity and some distortion," she writes. These interpretations can be distinguished by whether or not they are interior or exterior views: "Black Americans, like all ethnic groups, have developed various narrative versions of their past. These narratives can be called interior, in the sense that they were created by African Americans about their own experience" (Ruffins 1992, 510, 512). ${ }^{5}$ It is this interior view that some black connoisseurs feel that black staff at black museums exhibit in their work.

Along with black staff, some black connoisseurs also herald black museums for being more likely to employ black architects. The architectural field is overwhelmingly white: around 2 percent of American architects are black (Directory of African American Architects 2009; Syrkett 2017). For this reason, some black connoisseurs feel that it is particularly meaningful that black architects such as Phil Freelon and David Adjaye have been part of the architectural teams for black museums. As one black patron reflects, "I feel strongly that black architects need to have a role in the design of our black museums." Apprehension about black architects being excluded in the design of black museums is illustrated by the proposed legislation for the NMAAHC. Though it was not included in the final version, a statement addressing this concern read,

Due to the unique and historically sensitive nature of the project, the Architect of the Capitol and the Board of Trustees shall develop a program to ensure, to the maximum extent permitted by law, that African American architects and contractors have a central role in the design and construction of the Museum building and ground.

(National Museum of African American History and Culture Plan for Action Presidential Commission 2003, 119)

Along with viewing black museums as distinguished from their majority counterparts because of their higher proportions of black staff, some connoisseurs also see black museums as more successful in their support of black culture. They emphasize that while majority museums have become more racially inclusive, they continue to undervalue black history and culture. In these supporters' minds, black museums are necessary because they put a spotlight on black art and history that is still underrepresented at majority institutions. "People think, and so wrongly, that black art has made it," one supporter explains. 
A segment of black art has made it-a segment. Most of the black artists who have made it have been vetted by [majority] institutions that very few black artists can get into. If you look at the list of people who are at the top of the black art world today, they've gone to Yale, they've gone to Columbia. ... Those are not places that are open to everybody. It depends on access. Even knowing about ... that whole world depends on some sort of access that a lot of people don't know how to negotiate. Those places need recommendations from powerful people. All of this stuff depends on access and a lot of black people, poor black people, do not have that access. I think black museums mostly look at the work before they look at the credentials. That's been my experience. We look at the work. Does the work speak to our community? Does the work speak to the curator? I'm not like, "Where did you go to school?”

He goes on to describe how black museums have participated in the broader effort by the African American cultural community to recognize artists ignored by "mainstream" institutions:

There's a whole generation of African American artists who have not been embraced by the mainstream art world [but] have been embraced by the African American community... [These are] artists in their 60s and 70s and 80s who did not have opportunities to show at the Ambertown Museum, who did not have opportunities to show at mainstream galleries like the Spencer Telles Gallery. They showed at galleries within the black community. ... Recently, the Green Gallery [a black nonprofit gallery] in Amberton, which has been around since the ' 60 s, did a major retrospective of Bill David [an African American artist]. Bill David is an artist that's highly respected. But, he has not had a show at the Ambertown Museum. He has not had a show there, but thousands of people from the black community came out to see Bill David's work at the Green Gallery. ... [A] whole number of galleries and institutions that support black artists came together to celebrate this one man who would have never been celebrated in any of the mainstream galleries or institutions. His work is absolutely phenomenal.

In this connoisseur's eyes, it is black cultural institutions that have been, and are still, the vanguards in recognizing the value of black culture. Whereas some connoisseurs view majority museums as spaces where donations of black art and artifacts will be cherished because they are relatively rare, others have doubts that the works will be truly valued there. This latter view is illustrated by one collector when I asked him about photographs from his collection. Would he donate them to the black museum where he is a board member or the large majority museum a few miles away? 
There is no question it would be the African American museum. There is no doubt there at all. The only thing I will say about the Museum of Fine Arts which makes them a valuable or strong contender, not that I would, is their ability to restore objects or maintain them.... Certainly in this region, their conservation is the best.

"So for conservation you see them [the Museum of Fine Arts] as particularly admirable, but you didn't hesitate to say that it would be the Black Museum of Leafston. Why?” I ask.

Because I think it would be valued more by the African American museum than by the Museum of Fine Arts, Leafston. I don't know if the Museum of Fine Arts, Leafston, would even be interested. But, if they were, they [the photographs] would probably go in the basement somewhere. That might happen at the African American museum for a while [because] works on paper have to-they can't be exposed to light for long periods of time. But, I think that the African American museum would be more appreciative than the Museum of Fine Arts, Leafston.

In his assessment, the black museum's potential for greater appreciation of the photographs trumps the majority museum's potential for superior preservation of them. Along with being more inclusive of black artists, some connoisseurs, especially those who are black, also emphasize how black museums are still more welcoming for black audiences. "What I think African American museums do differently is find a different audience for art," one patron says.

People who visit the African American museum may not feel as comfortable or welcomed in a larger museum setting. ... African American museums tend to be more community-minded. ... People in the [black] community tend to feel that the Museum of African American Art, Ambertown, is theirs, as opposed to the Ambertown Museum, where they feel like, "Well, that's theirs." So, that's a big distinction. Especially for people with fewer resources. The feeling that there's something specifically for them, that they are being included, that this is about themthat matters.

As we have seen, connoisseurs are sensitive to a wide range of the cultural dimensions of black museums. This can be partly accounted for by their broader exposure to history and culture. Next, we will briefly explore how appreciators, who spend much less time engaged with art and history in their broader lives, are less sensitive to the cultural sides of African American museums. 


\section{Appreciators}

Whereas culture is at the center of how the typical connoisseur assesses the value of black museums, for most appreciators culture is more marginal. The distinct joining narratives of connoisseurs and appreciators cast in relief their varying concerns with culture. As we saw earlier, connoisseurs often give significant weight to cultural factors in explaining their initial participation in black museum philanthropy. In contrast, culture is less central in the first involvement narratives of appreciators. "I got involved with the museum about twelve to fourteen years ago," one appreciator explains.

A very good friend of mine was chair, and he was trying to recruit new board members. He asked me if I would join, and I couldn't say no to him. Other than that, I had visited the museum, but I had no particular burning interest in the museum. I'm not necessarily a museum guy. I ... got interested in it more so from the sense of it being a necessary institution for the community.

A trustee who lives in the historically black neighborhood where the museum she supports is located also notes that it was not a love of culture that motivated her to become a trustee. Instead, it was helping to ensure that the community has institutions that enhance the quality of life.

I would say that I'm not a big art collector. I like art, but I don't know artists like a lot of our board members do. But, I am passionate about having resources available to the people who live in our community. I think that we deserve access to high quality resources like museums and theaters and dining establishments, schools and all of those things, just as any other community. So often we're overlooked. The fact that we have the black museum is important to me and I want to make sure it stays available to us.

Culture per se is also not the main factor in how an executive explains her path to the board. "I've known Jaleesa [the director] ... for a long time. Just in the community and socially," she explains.

She called me up one day and asked if I would consider [joining the board]. I'm one of these people that gets asked to be involved in a lot of different things. So, there's kind of two criteria that I use in evaluating whether I'm going to get involved in something. One would be, "Is it a mission that I'm passionate about?" [The other is], "Can I make a difference?" Those are my two criteria. So I asked her. I went out to lunch and I said, "So, Jaleesa, why do you want me on the board?" At the time it kind of had 
a history of just being a big board [with] all the corporate companies in town. ... In talking it through with her, I felt there was an opportunity to do some things differently from a corporate governance perspective. ... So that's primarily why I've been involved. In terms of being passionate about it, what I'm passionate about is not so much the historical museum perspective of it. It's the fact that it serves as a venue for ongoing dialogue around race and really being a place in which divergent opinions can be put on the table, which I think is important. Particularly with everything going on these days, we need more venues like that.

For this trustee, bringing professional skills and knowledge to the board and supporting interracial dialogue were more central motivators for becoming a trustee than was an interest in history. The lesser weight that appreciators place on culture in defining what is important about black museums is evident in not only their joining narratives but also their limited focus on artists, objects, patrons, and curatorial staff. They typically pay less attention to them. And, when they do comment about them, they to tend to do so with less authority. For example, when I ask one appreciator about his opinion on the types of exhibitions that he would like to see his museum mount, he insists that he does not have the expertise to make such judgments. "Exhibitions? I'm probably not the right person to answer that. I'm really not," he comments. Similarly, an appreciator resisted answering specific questions about what artists should be presented in the museum where he is a trustee, saying, "I'm not a big art person. ... It's just not something I'm passionate about." One appreciator also questioned his fitness to participate in the study altogether, commenting, "I am not what you would consider a museum person. I don't know that this interview is really of value to you. ... I'm like a businessman workaholic type guy."

Along with giving less authoritative judgments related to cultural matters at black museums, appreciators are also typically less enthusiastic about their encounters with art and artifacts there. Or, while connoisseurs and appreciators share an appreciation of African American museums as institutions that facilitate audience encounters with culture, the latter often have a less passionate and nuanced appreciation of those encounters. When asked to describe their favorite exhibitions, appreciators often discussed them vaguely or talked about them without reference to their aesthetic dimensions. For example, an appreciator who enjoyed a solo exhibition described the show without reference to the name of the artist. "I can't remember the name of the artist," he admitted. "But, I liked the focus on the black family." Other appreciators made comments such as: "I can't think of a favorite [exhibition] off the top of my head. My interest is more on events than shows. A while back we had a health panel that was stellar" and "Last year, a dear friend was in town and I took her to the museum to see the show that was up then. We had a nice time catching up there." In instances when appreciators specifically name artists who are exhibited, it is generally more 
widely recognized artists. For example, appreciators are more likely to recall seeing the work of artists such as Romare Bearden and Elizabeth Catlett than that of more obscure artists.

Appreciators are also less concerned about opportunities to build their own cultural capital via their museum patronage. For example, when I asked a trustee if being on the board had shaped his interest in art he said, "To a degree, but I am not sure how much I've retained." This more neutral attitudes towards gaining cultural knowledge was also manifest in the comments of a trustee when I asked him if he sees any benefit to having a relationship with museum staff. "If I started a collection, Susan [the director] would be a big help," he says. "But, right now, I don't have the time or real interest in that." Appreciators are also less focused on the performance of curatorial staff. For example, one appreciator who is an executive made several comments about the management skills of staff but did not evaluate their curatorial choices.

Appreciators are also typically less focused on rankings within the field of African American museums. For example, in communities where there is more than one African American museum, appreciators are more likely to not be aware of the other museum or museums. Appreciators are mindful of large majority museums in their cities and often have a desire for African American museums to have a status that is more commensurate with them. In comparison to connoisseurs, however, they pay less attention to cultural differences in their rankings. For example, an appreciator who is a corporate executive envisions the museum where he is a trustee as a leading cultural institution in his city. However, unlike many connoisseurs, he focuses on improving management rather than cultural aspects of the institution. "It's incumbent upon us to raise our game and to be able to compete on the level [with mainstream museums]," he reflects.

If you are the only game in town, and people are coming to you, you can do things the way you've always done them. Now ... you have to earn their investment. ... So, we've got to raise our game in terms of how we do our business, having more of a business mentality that relates to our product. I'm not saying we should be a stone cold business. But, we should be an organization that exemplifies those kinds of business practices that will make it an exemplary arts institution. It's about leadership.... One of the worst things you can do as an art institution is to have an artist in charge.... It's the business side that supports the creative side, and that's where it has to be for strong advancement. There has to be strong fundraising. There has to be strong management. There has to be the kind of decision-making that does not bankrupt you, that provides an opportunity for us to grow, and to grow without letting the patient die.

Whereas connoisseurs more often emphasize how cultural improvements are necessary for raising status, this appreciator sees his museum as 
being able to manage its way to the top of the museum hierarchy. Other appreciators also emphasize noncultural dimensions of African American museums that they see as determinative of their organizational excellence, such as "fostering interracial understanding," "providing an outlet for neighborhood youth," and "being a place for the black community to come together." In the eyes of some appreciators, it is noncultural factors such as these that give black museums an edge compared to majority museums. How this view contrasts with connoisseurs is cast in relief by the comments of a collector who notes, "Programs for the community are needed, but we will never be seen as a great museum because of a health [or a] college fair. That's not what gets a good review by a critic. It's the art that counts."

To summarize, in contrast to connoisseurs, appreciators are less attentive to the cultural dimensions of black museums. Cultural considerations are less of a driving force in their initial decisions to become involved with black museums. Once they become supporters, appreciators are less concerned with the cultural facets of these institutions, such as the curatorial decisions of staff, and the cultural benefits of being a patron, such as deepening their personal knowledge of history and culture. In general, appreciators not only tend to be less sensitive to museum hierarchies, but they are also less likely to draw on cultural criteria to judge where black museums rank relative to majority museums. More broadly, they place less emphasis on noncultural criteria in determining whether or not black museums are "great organizations."

\section{Conclusion}

This chapter explores how supporters of African American museums think about their institutions' cultural value. I show how connoisseurs are highly attentive to the cultural dimensions of African American museums, whereas appreciators give less focus to their cultural side. I account for these differences by the greater exposure that connoisseurs have to art and culture.

This chapter deepens understanding of museum patronage. While the scholarship on museum patronage emphasizes how middle- and upper-class patrons share a love of culture (Bourdieu, Darbel, and Schnapper 1991), this chapter offers an alternative view. I find that upper-middle and upperclass patrons of black museums have varied lifestyles and only a subset are connoisseurs. This finding builds on Ostrower's (1999) research on majority cultural institutions: she shows that deep appreciation and knowledge about art is not shared by all board members. I extend Ostrower's scholarship not only by illuminating this finding within a new context-black museums-but also by elaborating how this lifestyle difference matters for how supporters evaluate museums. Fleshing out these differences offers a more in-depth understanding of museum values among the upper-middleand upper class. For example, Ostrower (2002) finds that trustees care deeply about organizational excellence. This chapter illustrates how patrons 
of black museums are also concerned with organizational excellence, but it is connoisseurs who place the most weight on cultural criteria for determining what is a great museum.

This chapter also offers important insight on museums and the aesthetic mobility of culture. Research on cultural valorization argues that one practice that spurs aesthetic mobility is the establishment of organizations that distinguish superior and inferior cultural producers and objects (Baumann 2007; DiMaggio 1992). For art and culture, museums are a central legitimizing organization (Braden 2009). This chapter deepens understanding of this process by exploring the role of cultural institutions in valorizing black art and artifacts. Just as the establishment of majority museums in the United States by cultural capitalists in the 19th century solidified distinctions between high and popular culture, upper-middle- and upper-class patronage of African American museums today is contributing to the hierarchization of black history and culture. It is connoisseurs who are most focused on African American museums playing this role. Their concern is not only that museums sort sacred and profane black culture, but also that the museums themselves enter into the realm of the worthy.

Finally, this chapter casts light on the role of African American museums in supporting the market for African American culture. While it has long been understood that museums are an important player in cultural markets because of their role in establishing taste and legitimizing cultural producers and objects (Khaire 2017), black museums have largely been excluded from this discourse. This chapter's explication of connoisseurs' appreciation of African American museums as supporting the market through legitimizing art and artists and socializing collectors spotlights the intersections of black museums with cultural markets. In the next chapter we turn our lens to generation to examine how patrons born in different age cohorts understand the value of the contemporary in black museums.

\section{Notes}

1 To protect confidentiality, this chapter uses pseudonyms not only for interviewees and cultural institutions but also in some cases for artists.

2 The analysis in this chapter centers on how connoisseurs and appreciators define the cultural value of black museums. Although there are fundamental differences in the cultural evaluations of connoisseurs and appreciators, it should be noted that there are subtle differences in cultural evaluation within these groups. Among connoisseurs, cultural values vary depending on degree and type of connoisseurship. For example, some patrons are new to collecting, whereas others have been collecting for decades. Both the new collector connoisseur and the longstanding collector connoisseur can be distinguished from noncollector appreciators by their greater emphasis on the cultural value of black museums, but it is typically long-standing collector connoisseurs who place the greatest emphasis on the cultural value of these institutions. Connoisseurs' areas of cultural interests also vary. For example, in comparison to connoisseurs who are deeply engaged in 


\section{The connoisseur's eye}

history, connoisseurs with high involvement in fine art appear more sensitive to certain issues such as specific artists who have gone unrecognized. There are also racial differences among connoisseurs, with black connoisseurs more sensitive to issues such as hiring black staff at black museums.

3 David Halle (1993) makes a similar argument concerning the appreciation of abstract art by the upper-middle and upper class. In his research examining art in the homes of New Yorkers, he finds that residents of upper-middle- and upperclass neighborhoods are more likely than those in working-class neighborhoods to display abstract art. However, while members of the upper-middle and upper class may be more likely to own abstract art, Halle (129-131) finds that a slight majority appreciate it for its merely decorative qualities.

4 In his research on race and art prices, the economist Richard Agnello (2010) compares prices for art by black and white painters from 1972 to 2004. Despite narrowing over time, a price gap favoring white artists existed throughout this entire period. There has also been underrepresentation of contemporary African art in the art market (Banks 2018).

5 Concerns about interior views have also surrounded museums associated with other racial and ethnic minority groups, such as Native Americans (Lonetree 2012; Simpson 1996).

\section{References}

Agnello, Richard. 2010. "Race and Art Prices for African American Painters and Their Contemporaries." Journal of Black Studies 41(1): 56-70.

Alexander, Victoria D. 1996. "From Philanthropy to Funding: The Effects of Corporate and Public Support on American Art Museums." Poetics 24(2-4): 87-129.

Andersen, Margaret L., and Neil F. Thomas. 2009. Living Art: The Life of Paul R. Jones, African American Art Collector. Newark, DE: University of Delaware Press.

Balfe, Judith Huggins, and Thomas A. Cassilly. 1993. “'Friends of ...': Individual Patronage Through Arts Institutions." In Paying the Piper: Causes and Consequences of Art Patronage, edited by Judith Huggins Balfe, 119-134. Urbana, IL: University of Illinois Press.

Banks, Patricia A. 2017. "Collecting African American Art: From the Harlem RenaissancetotheObamaEra."BlackPast.org,August 10,2017.AccessedAugust 15, 2018. www.blackpast.org/perspectives/collecting-african-american-art-harlemrenaissance-obama-era.

- 2018. "The Rise of Africa in the Contemporary Auction Market: Myth or Reality?” Poetics 71: 7-17. https://doi.org/10.1016/j.poetic.2018.05.004

—. 2019a. "Cultural Justice and Collecting: Challenging the Underrecognition of African American Artists." In Race in the Marketplace: Crossing Critical Boundaries, edited by Guillaume D. Johnson, Sonya A. Grier, Kevin Thomas, and Anthony Kwame Harrison. London: Palgrave.

—. 2019b. "Black Artists and Elite Taste Culture." Contexts.

Baumann, Shyon. 2007. Hollywood Highbrow: From Entertainment to Art. Princeton, NJ: Princeton University Press.

Becker, Howard S. 1982. Art Worlds. Berkeley, CA: University of California Press. 
Benzecry, Claudio E. 2014. "An Opera House for the "Paris of South America": Pathways to the Institutionalization of High Culture. Theory and Society. 43(2): 169-196.

Bourdieu, Pierre. 1993. The Field of Cultural Production. Cambridge, UK: Polity Press.

Bourdieu, Pierre, Alain Darbel, and Dominique Schnapper. 1991. The Love of Art: European Art Museums and Their Public. Cambridge, UK: Polity Press.

Braden, Laura E. 2009. "From the Armory to Academia: Careers and Reputations of Early Modern Artists in the United States." Poetics 37: 439-455.

Childress, Clayton. 2017. Under the Cover: The Creation, Production, and Reception of a Novel. Princeton, NJ: Princeton University Press.

Completed Questionnaires. 2003. Smithsonian Institution Archives, Accession 07-172. Washington, DC: National Museum of African American History and Culture, Planning Records.

Dávila, Arlene. 2008. "From Barrio to Mainstream: On the Politics of Latino/a Art Museums." In Latino Spin: Public Image and the Whitewashing of Race, Dávila, Arlene, 119-137. New York, NY: NYU Press.

- 2012. Culture Works: Space, Value, and Mobility Across the Neoliberal Americas. New York, NY: NYU Press.

DeVos Institute of Arts Management. 2015. Diversity in the Arts: The Past, Present, and Future of African American and Latino Museums, Dance Companies, and Theater Companies. Washington, DC: DeVos Institute of Arts Management.

DiMaggio, Paul. 1982a. "Cultural Entrepreneurship in Nineteenth-Century Boston, Part 2: The Classification and Framing of American Art." Media, Culture, and Society 4: 303-322.

—. 1982b. "Cultural Entrepreneurship in Nineteenth-Century Boston: The Creation of an Organizational Base for High Culture." Media, Culture, and Society 4: 33-50.

1991. "Constructing an Organizational Field as a Professional Project: U.S. Art Museums, 1920-1940." In The New Institutionalism in Organizational Analysis, edited by Paul J. Dimaggio and Walter W. Powell, 267-292. Chicago, IL: University of Chicago Press.

1992. "Cultural Boundaries and Structural Change: The Extension of the High Culture Model to Theater, Opera, and the Dance, 1900-1940.” In Cultivating Differences: Symbolic Boundaries and the Making of Inequality, edited by Michèle Lamont and Marcel Fournier, 21-57. Chicago, IL: University of Chicago Press.

Directory of African American Architects. 2009. "Percentage of African American Architects in Each of the Fifty States \& USVI." Directory of African American Architects. Accessed June 1, 2018. http://blackarch.uc.edu/publications/black_ architects_by_state.pdf.

Fine, Gary Alan. 2004. Everyday Genius: Self-Taught Art and the Culture of Authenticity. Chicago, IL: University of Chicago Press.

Gans, Herbert J. 1999. Popular Culture and High Culture: An Analysis and Evaluation of Taste. New York, NY: Basic Books.

Griswold, Wendy and Hannah Wohl. 2015. "Evangelists of Culture: One Book Programs and the Agents who Define Literature, Shape Tastes, and Reproduce Regionalism.” Poetics 50: 96-109.

Halle, David. 1993. Inside Culture: Art and Class in the American Home. Chicago, IL: University of Chicago Press. 


\section{The connoisseur's eye}

Khaire, Mukti. 2017. Culture and Commerce: The Value of Entrepreneurship in Creative Industries. Stanford, CA: Stanford University Press.

Lena, Jennifer C. 2012. Banding Together: How Communities Create Genres in Popular Music. Princeton, NJ. Princeton University Press.

Lonetree, Amy. 2012. Decolonizing Museums: Representing Native America in National and Tribal Museums. Chapel Hill, NC: University of North Carolina Press.

McGlone, Peggy. 2016. “Before Smithsonian's Opening, Smaller African American Museums Grapple with a Behemoth in D.C.” Washington Post, March 2, 2016. Accessed June 10, 2017. www.washingtonpost.com/entertainment/museums/ before-smithsonians-opens-smaller-african-american-museums-grapple-with-abehemoth-in-dc/2016/03/02/ed151ea8-d58d-11e5-be55-2cc3c1e4b76b_story. html?utm_term=.e5c84a6bd994.

National Museum of African American History and Culture Plan for Action Presidential Commission. 2003. The Time Has Come: Report to the President and to the Congress. Smithsonian Institution Archives, Accession 07-172. Washington, DC: National Museum of African American History and Culture, Planning Records.

Ostrower, Francie. 1999. “The Arts as Cultural Capital among Elites: Bourdieu's Theory Revisited.” Poetics 26: 43-53.

- 2002. Trustees of Culture: Power, Wealth, and Status on Elite Arts Boards. Chicago, IL: University of Chicago Press.

Pachucki, Mark C. 2012. "Classifying Quality: Cognition, Interaction, and Status Appraisal of Art Museums.” Poetics 40(1): 67-90.

Rosenberg, Karen. 2016. "Collecting with a Conscience: At Home with Tribeca's Bernard Lumpkin and Carmine Boccuzzi.” Artspace, February 26, 2016. Accessed February 10, 2017. www.artspace.com/magazine/interviews_features/how_i_ collect/collecting-with-a-conscience-at-home-with-tribecas-bernard-lumpkinand-carmine-boccuzzi-53536.

Ruffins, Fath Davis. 1992. "Mythos, Memory, and History: African American Preservation Efforts, 1820-1990.” In Museums and Communities: The Politics of Public Culture, edited by Ivan Karp, Christine Mullen Kreamer, and Steven D. Lavine, 506-611. Washington, DC: Smithsonian Institution Press.

Simpson, Moira G. 1996. "Native American Museums and Cultural Centres." In Making Representations: Museums in the Post-Colonial Era, edited by Moira G. Simpson. London, UK: Routledge.

Syrkett, Asad. 2017. "On Race and Architecture." Curbed, February 22, 2017. Accessed June 10, 2018. www.curbed.com/2017/2/22/14677844/ architecture-diversity-inclusion-race.

Trescott, Jacqueline, and J. Freedom du Lac. 2012. “African American Museum's Fundraising Models: King Memorial and Obama Campaign.” Washington Post, February 17, 2012. Accessed January 10, 2017. www.washingtonpost.com/ entertainment/museums/african-american-museums-fundraising-models-kingmemorial-and-obama-campaign/2012/02/09/gIQA5QW9JR_story.html?utm_ term $=.7 \mathrm{~b} 7 \mathrm{da} 774 \mathrm{a} 123$.

Velthuis, Olav. 2005. Talking Prices: Symbolic Meanings of Prices on the Market for Contemporary Art. Princeton, NJ: Princeton University Press.

Zolberg, Vera L. 1981. "Conflicting Visions in Art Museums.” Theory and Society 10(1): 103-125. 


\section{A new generation}

Gina Charles grabs her phone, tilts her head to the side, and takes a selfie. Susan James hands her phone to her husband, lays her hand softly on her hip, and smiles as he snaps a photo. Gina, who is in her late 20s, takes photos all night long at the Goldsville African American Museum Galagroup selfies, shots with friends, photos of the dance floor, and on. Susan, who is in her early 70s, opts for fewer photos, but she poses for a couple arm in arm with her girlfriends. The next day Gina posts the best selections from her gala photographs to her Instagram account. Within the next several hours, friends who are tagged in the photos begin writing comments on the posts. Several weeks later Susan's photos are still in the cloud. She has a Facebook page where she could presumably upload them, but she is an infrequent user of the social media site. This year's photos from the museum fundraiser will likely meet the same fate as Gina's photos from last year's event-forgotten in a private digital abyss.

The centrality of social media in Gina's gala experience, and its more marginal role in Susan's, illustrates the varying emphases that patrons from different generations place on new technology in the context of African American museums. This chapter explores this and other generational differences in how patrons think about African American museums as contemporary cultural spaces. More specifically, I examine their views about the ideal place of contemporary culture, technology, and politics in these museums. I find that supporters' emphasis on the contemporary is inversely related to their generational status. Younger supporters, or those born after 1965 , tend to place the greatest emphasis on technological, political, and cultural developments that emerged in the 1990s and beyond. ${ }^{1}$ Culturally, they often place more value on highlighting contemporary visual artists, such as Kehinde Wiley, in museum exhibitions, and featuring contemporary music, such as hip hop, at museum events. ${ }^{2}$ Politically, this group often underscores highlighting political issues of today, such as Black Lives Matter, in African American museums. And, technologically, younger supporters typically call more attention to integrating social media and other new technology, such as apps like Twitter, into black museums. Engaging the broader sociological literature on generations, I mainly account for these differences by the 
varying exposure that younger and older supporters have had to contemporary culture, politics, and technology.

By making this argument, this chapter not only casts fresh light on philanthropy at African American museums, but it also offers new insights for sociological research on museum patronage more broadly. Despite the fact that museums are increasingly recruiting younger philanthropists as a way to protect their long-term financial interests (Gelles 2014), scholarship on cultural patronage has largely neglected generational divisions in how supporters value museums. This chapter makes clear that this new younger class of patrons does not think the same way about museums as their older counterparts. Before delving into generational differences in patrons' values at African American museums, I provide more background on the recruitment of younger patrons at museums and sociological theory on generations.

\section{Generations and museum patronage}

Although we know very little about how generational status orders museum values, we do know that museum patronage has tended to be an avocation for those members of the upper-middle and upper class who are more advanced in age. One national study finds that just over one-third (35 percent) of arts boards in the United States have any trustees who are under 35 , and on average supporters in this demographic constitute 6 percent of board members (Ostrower 2013, 24). Another national study focusing specifically on museum boards in the United States finds that just 26 percent of board members are under 50 (BoardSource 2017, 8). Yet, while younger patrons are still atypical in the world of cultural philanthropy, they are being heavily recruited by cultural organizations. Partly in response to reports that arts audiences are "graying" and not being replaced by younger cohorts, museums across the nation have formed special young professional support groups for patrons in their 20s, 30s, and 40s (Gelles 2014). ${ }^{3,4}$ Their aim is to establish a support base for the future. In New York alone, a museuminclined 35-year-old can join groups such as the Young Professionals Program at the Weeksville Heritage Center (an African American museum), the MOCA Young Professionals at the Museum of Chinese in America, the Junior Associates at the Museum of Modern Art, the Apollo Circle at the Metropolitan Museum of Art, and the Young Collectors Council at the Guggenheim Museum. Exploring the case of African American museums, I show how the values of these younger patrons often depart from those of their older counterparts.

To help explain why generational differences exist, I turn to sociological theory on generations. The German scholar Karl Mannheim (1952) argues that each generation has a distinct worldview. People who are born during the same period of time and encounter history together develop a shared consciousness. This generational worldview is particularly shaped by events and experiences taking place from adolescence to young adulthood. 
Applying Bourdieu's concept of the habitus to generational theory, some scholars assert that distinct encounters with history among age cohorts produce a generational habitus that then structures perceptions and values (Eyerman and Turner 1998). Unlike worldviews associated with the life cycle that are expected to shift as people age, generational orientations stay with members of an age cohort throughout their lifetimes (Glenn 2003, 465-476).

Scholars of race theorize that generational status shapes political and cultural orientations related to African Americans. In her research on political activism among urban black youth and other youth of color, Andreana Clay (2012) argues that their political engagement is informed by a distinct generational logic-specifically, a post-civil rights generational logic. Clay distinguishes the worldview of the post-civil rights generation (typically defined as those born after 1965) with that of the civil rights generation. In contrast to the generation that came of age during legalized segregation, the post-civil rights generation spent its formative years in a decidedly different political and cultural environment. On the one hand, the passage of the 1964 Civil Rights Act and other civil rights legislation meant that the post-civil rights generation was born into a world where citizenship in the United States was presumably no longer restricted by race. Moreover, black popular culture rose in prominence to an unprecedented level as hiphop music became a global phenomenon. As the journalist Keli Goff (2008, 7) writes of this generational divide,

Not only has the post-civil rights generation grown up in an America in which segregation is a distant memory, but it has grown up in an America in which black people and black culture are the defining arbiters of America's cultural landscape.

However, as Clay reminds us, despite new freedoms and the worldwide spread of black culture, the post-civil rights generation encounters continuing inequalities, such as the prison industrial complex and police brutality.

Applying these perspectives to the context of black museum patronage, we can see that younger supporters' emphasis on new culture, new politics, and new technology may be at least partly a product of coming of age in the contemporary era, when cultural forms such as hip hop emerged and rose in prominence, inequalities such as police shootings became more visible, and technological innovations such as social media were developed. Younger patrons were not only exposed to these political issues and cultural and technological forms in their formative years, but they also continue to be more engaged with them now relative to older supporters. ${ }^{5}$

Alongside greater exposure to these new forms of culture, politics, and technology, other factors, such as various patron roles linked to different stages of the life cycle, may also influence younger supporters' focus on 
the new. Trusteeship is a philanthropic role that is typically taken on in the more advanced stages of adulthood (Ostrower 2013). I suggest that younger patrons' less traditional outlook concerning contemporary political issues being engaged at black museums may be related to their lower likelihood of serving as trustees. More specifically, being less likely to serve as trustees who assume responsibility for museum governance may make younger trustees less traditional in their outlook. Below, I discuss generational differences in more detail. I begin with technology.

\section{Technology}

Ben opens the front door of his 19th-century brick home and welcomes me in for our interview. He is dressed in jeans, a red-and-white-striped buttondown shirt, and a baseball hat. We walk down to his first-floor office, where I sit on a couch and he sits at his desk. Ben's smart phone is perched on the side of his desk. Though he is attentive as he talks, at times he picks up the phone and looks down to check the screen. A couple of days later, I talk with Erica, another Millennial patron, in the atrium of the museum that she supports. This interview also features a cell phone as part of the backdrop. This time, the phone stands alert on the table where we sit, supported by a small stand. As we talk, she occasionally picks up the phone and presses a button or two. In stark contrast to their younger counterparts, the cell phones of the older supporters whom I interview are more often put away during interviews or, if out, are not toggled or glanced at.

The higher degree of interaction that younger supporters have with their cell phones during interviews is indicative of their views about the appropriate role of technology at black museums. While both younger and older patrons typically believe that new technology is generally important for African American museums, the former more often emphasize how it is valuable for their personal engagement, and they have more specific recommendations about how it should be utilized in a museum environment. Sociological theory on generations and technology asserts that generational differences in technological orientations emerge from distinct technological habituses (Sackmann and Winkler 2013). Because technological revolutions emerge in different time periods, each generation is exposed to different types of technology during their formative years. Younger members of Generation $\mathrm{X}$ spent late adolescence and early adulthood in the dawn of the internet revolution, and Millennials have come of age during the rise of social media. For these groups, especially "digitally native" Millennials, new technology regulates the rhythms of their daily lives. Smartphones with apps, such as Facebook, Instagram, and Twitter, are kept at hand from morning until night. While all age cohorts have become more engaged with the internet across time, there is still a higher percentage of use among each successively younger cohort. For example, Millennials are more likely than GenXers to listen to music online, play online games, and use social networking 
sites, just as Gen-Xers are more likely to engage in these activities than baby boomers and so on (Zickuhr 2010, 1).

Megan is typical of Millennial black museum patrons. In her view, social media at the museum she supports is "very, very, very important." "Just because I feel like the majority of my generation ... consumes everything on social media," she explains.

People are consuming everything on Facebook. I don't know what the stats are off the top of my head, but I feel like about 60 percent of people get their news from social media. So, if you have an event [at the museum], and you share [it] on social media, it's the best way to plug in and stay in touch with family [the museum community]. I think it's very, very important for institutions to be leveraging social media to reach out to people. And, it's free.

Megan herself is engaged with the museum via social media. When I ask if she follows the museum on various channels, she replies, "Yes, I am connected. I follow [the museum] on Facebook and Twitter and Instagram. ... It is a really good way to just keep up with what's going on. ... It pops right up in my newsfeed." She also uses social media to connect her social network with the museum. "A lot of events kind of come up more word of mouth and you can invite people via Facebook," she says. As part of her patronage, Megan helps to organize events at the museum for younger supporters. Digital platforms are used to enhance their engagement during and after events. "When we go through the event planning process, we'll hire a photographer to come," she explains.

And, then a good way to get people to post on their own is to have a hashtag associated with the event. That way you can encourage people to post their own photos. You use the hashtag and so it's kind of like a multiplier effect. Of course you want your own photographer, but it's great if you have [attendees] sharing and posting photos online. Another thing that we did for a [recent fundraiser] was we had ... a photo-booth so people could have the funny glasses or hats or mustaches. That is also linked to a digital platform where all the photos are uploaded and people can search the photos. So again, there is a multiplier effect where everything is searchable online and on social media. ... I think we got some good videos too that we are sharing on social media.

Megan's emphasis on social media at the museum is Millennialist for its emphasis on using social media not only to build museum engagement but also to track online engagement.

It's free [tracking], and there are tons of online tools that you can use to track impact too-how many clicks you're getting, how many people 
commented on a post. Or, people can even message you directly to say, "Okay, I want to partner with you on this event." We've had a ton of that happen from our [young professional group's] Facebook page, so there are just tons of opportunities.

Megan's familiarity and facility with digital tools to enhance museum engagement is typical of other younger supporters, such as Jane. When I ask Jane, also a Millennial patron, about her level of involvement with social media, she rapidly ticks off a list of her accounts. "I do it all, Facebook, Twitter, Instagram, Snapchat, LinkedIn," she says. Social media is so infused in her daily life that it is a part of her morning routine. "I was talking to a friend recently, and he kind of got on my case," she recounts.

He's like, "When you get up in the morning you should turn on the news." I am like, "No, when I get up in the morning, I go to Facebook because everything I want to see is right here on my phone." [After that] I will turn on the news.

Like Megan, Jane also feels that the museum she supports needs to be deeply engaged with social media:

Not only is it important to me in my personal life, but it's also important for my organization [the museum] to make sure that we are keeping people informed with information that is important to them. And, it doesn't have to be what's the latest news. It could even be, "Hey, we have this wonderful artist who was just awarded whatever," just throwing something out there. That is great news. Let's share it. Let's get it out there. Let people know that we are doing great things. ... It's important that we keep our social media pages updated with interesting content and content that matters to our audience.

When there are museum events, Jane gets the word out through social media. She tries to connect with as many people in her social network as possible.

I feel like it's [reaching out to] everyone that I come in contact with, whether it is a friend that I've known my entire life, my mom, or my grandmother who lives in the South. I am even like, "Grandma, hey share this," just because, who knows, someone might [travel to the city] and now they know about this great museum. So, I share it with everyone once it's up on the museum's site. It is all about resharing, saying, "Hey, here is this great event. Come out."

Like Megan, when Jane is working on events for younger patrons she encourages them to pose for photos so that they can be posted online: "I'll 
say, 'Hey, stop and take a picture, so we can tag you.' " Jane also feels that the museum benefits from articles written about it for digital media, such as online sites for the local news. These articles, as well as social media sites like Facebook, offer direct insight into how people are responding to the museum. She contrasts publicity through these online channels to publicity in traditional print and television media. In her opinion the former are especially valuable, because "you are getting the online comments."

You are finding out what people are interested in, what they're passionate about, what is driving them, what their concerns are. And, then you can go back and do something about it. When we post on our page, I look at the number of likes or shares or visitors. I see this post received, just throwing out a number, two thousand views, and I see this one received only one hundred. What's the difference? I look at the content and say, "Oh, our audience is interested in this." So for me social media is crucial.

While Gen-X patrons are often fairly personally engaged with social media and staunch advocates of black museum online involvement, their emphasis is often not as great as Millennials. For example, one Gen-Xer shares that though he is Facebook friends with the black museum that he supports and he likes posts from the museum, he rarely takes the time to write comments on posts. Marcus, who is also in his early 40s, explains that though he is now an avid consumer of culture online, including but not limited to black museum engagement and buying art, his Millennial sibling became engaged before he did. He fondly recalls that when his younger brother introduced him to Facebook by posting a family photo on the site, he felt that it was a violation of privacy. "He had this innocent picture of me and my dad, and I was like, 'You are going to remove the link.' Right?" he says laughing.

While younger supporters are often highly personally engaged with the social media sites of the black museums that they support, older supporters are typically less individually engaged. This is certainly the case for Dan, a trustee who is a member of the Silent Generation. Like several other older patrons, Dan explains his lack of engagement by age. "I am not much of a social media guy to be honest with you. ... I'm too much of a dinosaur," he says with a chuckle. Allen, a fellow member of the Silent Generation, also uses the metaphor of a dinosaur from a pre-social media epoch to justify his lack of engagement with his museum's social media sites. "It's hard enough for me to keep up with my emails. I'm not involved in any form of social media at all. I guess that's sort of the dinosaur in me," he says. Joanna, a baby boomer, also relates her lack of online engagement with her museum's social media sites with age:

I'm not involved in the [museum's] social media. I'm too old to be involved in social media. But, our director has been blogging, and we've 
got a much bigger social media presence thanks to our media director. I think it took us kind of a while to come around to that. The board is the typical board. I am 55, and I am one of the youngsters. We've got a much greater social media presence then we used to have, and hopefully that will just increase. But, expecting our board to be posting on Twitter and stuff, I don't know about that. Maybe the next round of board members will be some younger people.

When I ask Janet, a Younger Boomer, if she is engaged with the museum's social media pages, she laughs and says, "I'm old, so no." But, Janet does believe that social media is valuable for the museum. "I think it's very important," she explains.

This younger generation, they pay attention to all that stuff. That's part of how they communicate. ... It's stuff that goes beyond me. ... I've got an au pair that lives in my house, and she refuses to e-mail me stuff. I say, "Why won't you e-mail?" [She says,] "Oh, I'm just going to WhatsApp it," and I'm like, "No, email it to me." Being in tune with all that, having a face in all those different areas is important. Museums have got to be. I think part of the challenge for any museum is that you have to remain relevant. That means that as the population changes, you've got to change too, right? You've got to be relevant, and for something like [our museum] that means that you've got a lot of different stakeholders because what's important to a 60 -year-old is going to be different than what's important to a 25 -year-old. So you've got to be able to span that whole spectrum if you're going to stay relevant, right?

Other older supporters also emphasize that even if they are not personally engaged with social media, they know that online engagement is an important tool for black museums to capture the attention of younger patrons. For example, John is an Older Boomer who says he is not "on any social media sites" and does not think his "generation has grasped it." But, in his opinion an online presence for the museum he supports "is very important for the group behind us." While some older supporters, such as John, have essentially zero social media engagement in general and with the museums that they support, others, like Jack, have minor involvement. When I ask Jack, a member of the Silent Generation, if he is connected to social media he simply answers, "No." "I'm not a young man. ... I just haven't found the space or the time in my head to follow that," he explains. Though not on social sharing sites, he is on the museum's e-mail list.

I'm on their mailing list, and when I get something that interests me, I immediately click on it, and I go and I follow up on what's available on the website. But I don't feel an obligation to go to a Twitter feed or keep it on my desktop so that I can stay aware of what's going on. 
Ada, a Younger Boomer, also has a minor level of involvement in social media. Although she has a Twitter account, she does not follow or tweet about the museum where she is a supporter. "I have a Twitter account, but I don't use it," she explains.

I am old school. ... I just don't want all of my life in the public like that. So, I've not done Facebook. I have a Twitter account, but mostly because at the time [when she joined] it was really hot. I was leading a class at my church with a group of young people. They all convinced me that that [Twitter] was the only way that I could ever communicate with them and make sure that they were going to be in class.... So I had it for that, and I don't do anything with it. I don't even know how to tweet. It's terrible. I don't have Instagram. I don't have any of that stuff. I don't even have a LinkedIn account, which is bad. I keep saying I'm going to get one of those because apparently that's the way you get jobs if you need them these days.

While Ada has light engagement with social media, partly because of concerns about privacy, she nonetheless sees a need for the museum where she is a trustee to "stay up to date with new technology." Indeed, across generations patrons typically concur that for African American museums to flourish they must be up to date with the newest technology. However, younger supporters more often emphasize how digital technology is important for their personal involvement with museums and more often offer concrete advice on how to best utilize it. In contrast, older supporters often do not view their personal engagement with black museums as being significantly dependent on their technological infrastructure, and they are less likely to offer specific recommendations on how it should be used. More typically, they offer broad recommendations, such as "the museum should be involved with social media" and "we need to be online," rather than endorsing specific social media channels and proposing how to optimize their use, such as monitoring comments. Next, we will see how older and younger patrons think about contemporary culture in black museums.

\section{Culture}

It is a Saturday night in June 2017, and Chance the Rapper is onstage at the DuSable Museum of African American History's fundraising gala, "A Night of 1000 Stars." Wearing a brown baseball cap and red suit accessorized with a Kente cloth pocket square, he grips the podium and then picks up the mic. “... I'm proud to announce that I will be donating my hip hop album of the year award, the first one to a black independent artist, to the DuSable museum in the coming weeks," he says (Chance the Rapper 2017). A few months earlier, it was announced that Chance, a longtime Chicago resident and 2017 Grammy winner for Best New Artist, was joining the board of the 


\section{A new generation}

DuSable. Born in 1993, Chance is an outlier among museum trustees. But, it is in fact his Millennial status that appealed to Perri Irmer, the museum's director. After becoming CEO and president of the museum in 2015, Irmer sought to broaden the museum's support base. "I'm not going to pretend I'm not super excited about Chance," Irmer said. "It brings us his generation, right? I've got three daughters, 21 to 34. They're like, 'Mom, ohmigod!'” (Johnson 2017).

Indeed, fans of rap music are more concentrated among younger arts audiences (Peterson et al. 1996, 114). In the case of black museum philanthropy, younger patrons often place a heightened emphasis on hip hop and other forms of contemporary culture being inside the walls of African American museums (see Figure 5.1). As sociologists like Andreana Clay (2012) theorize, the cultural touchstones of various generations differ. For example, whereas baby boomers came of age during the birth of the Motown Sound, Generation Xers and Millennials came into their musical maturity when hip hop ruled the national and global airwaves. While older supporters do not reject the notion of African American museums as contemporary cultural spaces, their concern and interest in the contemporary is typically not as great as with their younger counterparts. Similarly, while cultural forms that were at their height in earlier periods interest younger supporters, in balance they are typically less enamored with them than are older patrons. Generational gaps in experience and knowledge mean that

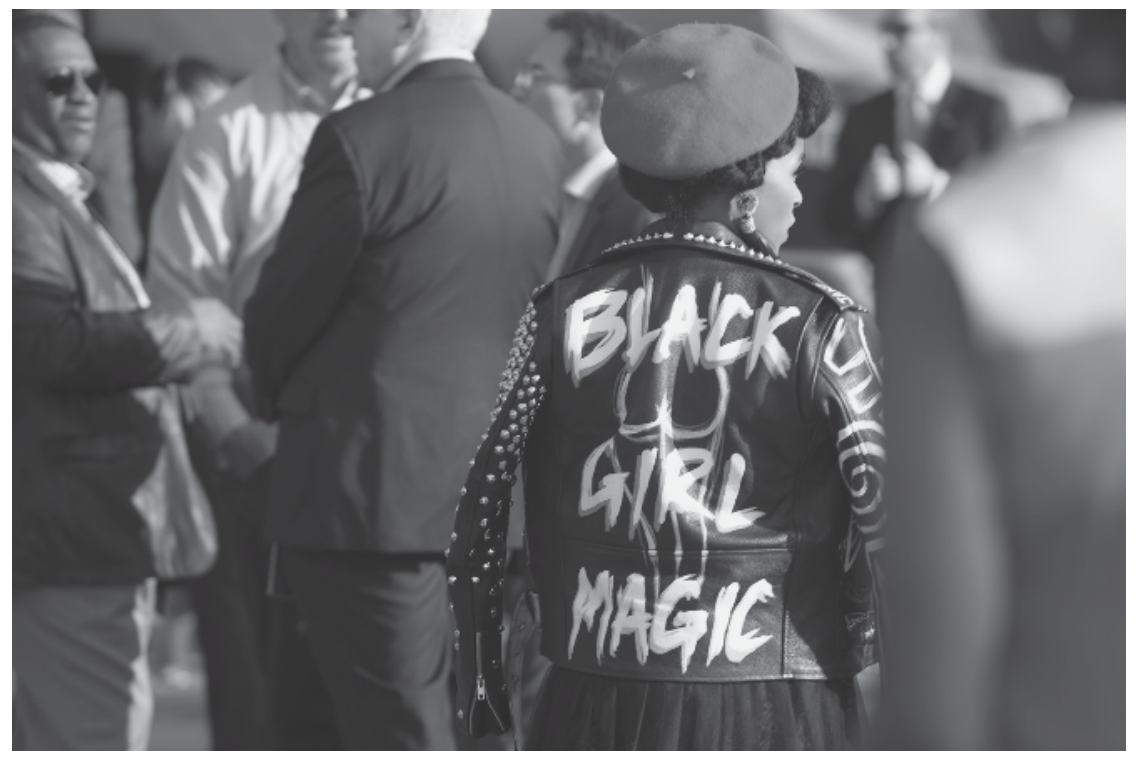

Figure 5.1 The Millennial singer, rapper, and actress Janelle Monáe in a Black Girl Magic jacket at the opening ceremony for the National Museum of African American History and Culture. Leah L. Jones for the NMAAAHC. 
cultural forms that are instantly recognizable and deeply significant to one age cohort of patrons can be foreign or less consequential to another.

Thomas, a supporter in his late $30 \mathrm{~s}$, describes the different cultural preferences of himself and his parents. "When it comes to music, our tastes depart some," he says.

I'm mainly into rap. My parents are into old school rhythm and bluesthe Supremes, Marvin Gaye, the Jackson Five, all of that. A while ago they went to Barry Gordy's old studio in Detroit-it's a museum [The Motown Museum] now. ... I think my dad might make a small donation [there].

Jake has no specific plans to visit or donate to this Detroit museum. But he is excited about two new hip hop museums-the Hip Hall of Fame Museum and the Universal Hip Hop Museum-that are in the works.

The greater orientation towards hip hop among some younger patrons is reflected not only in their interest in museum collections, but also in the music that is featured at museum events. As one Millennial supporter says, he favors a "hip hop vibe" at museum fundraisers and other events. Younger supporters' interest in a hip-hop vibe was evident at Public Enemy's concert at the NMAAHC opening. That evening the rap group took the stage as part of the "Freedom Sounds: A Community Celebration" festival. On the lawn overlooking the museum and the Lincoln Monument, a central stage was set up. Farther back large television screens projected the main stage amidst large stadium lights that illuminated the dark field. "All the real hip hop heads, stand to your feet right now," a voice from the stage shouts out. The crowd cheers. "Put your fist in the air to salute living legends of hip hop, Puuubliiiiic Enemy." Across the lawn a mostly black but racially mixed crowd of people who appear to be mainly in their 20s, 30s, and 40s raise their right arms and hold their hands in tight fists mimicking a gesture that has come to define the group's brand. As the evening wears on, some concert-goers dance enthusiastically and others coolly sway to the beat. To be sure, the absence of a large contingent of older supporters, such as members of the Silent and G.I. Generations, at the late-night concert is due partly to lifestyle patterns that accompany older age. Attending an evening concert with booming music on a grass field may also not be to the taste of younger supporters as they age. But distinct generational musical tastes also likely play a role. Or, it is the type of music that was being played that also shaped who ended up going to the concert. Earlier that morning, as I sat on the same grass waiting for the museum's opening ceremony to start, I overheard an intergenerational family group organizing their schedule for the day. "I think PE [Public Enemy] is playing tonight," a woman who looked to be about to be in her late 30s said to her mother, as she glanced through her phone. Her mother responded "PE?" with a quizzical look, suggesting that she was unfamiliar with the group. 
Along with contemporary music, generational distinctions also map onto supporters' interest in contemporary visual culture. Younger generational supporters often have a heightened interest in younger artists. When one Gen-X patron names the artists in his personal collection and those he most likes to see in black museums, the majority—such as Sanford Biggers and Kara Walker-were born in the post-civil rights era. A fellow Gen-X patron and collector notes how he and his partner "spend a lot time with contemporary, younger artists." As personal champions of this post-civil rights generation of African American artists, these are the artists whose work they are especially excited to see in black museums.

Samanatha, also a member of Generation X, does not collect expensive works of art. "But, when I see a piece that jumps out, if it's fifty dollars or less I'll take it," she explains. When I ask if she has a favorite artist, she recalls an exhibition by Kehinde Wiley at a museum that neighbors the black museum that she supports: "Do I have his pieces? No. But, I was over the moon and out of myself when he had that show." She laments the fact that the black museum where she is a member of a friends group did not get the show. "We didn't get him, but it was a beautiful exhibit. I took a picture with him. He's the best. I loved the colors."

Wiley first became recognized for his brightly colored large-scale paintings of urban black men reimagined in classical European portraits and became a household name when his portrait of President Obama was unveiled at the National Portrait Gallery. He is also a favorite of other younger supporters like Susan. Susan is a member of a support group at one of her city's black museums. "In the last few years Kehinde Wiley's pieces have been really, like wow, right?" she says. "Why, because it's the same style as some of these classics, right? ... The classics are not for me, but his pieces are. As long as it feels like it's real, I think that's socially relevant to my generation."

Shawn, a Gen-Xer, expresses disappointment about what he sees as a lack of faith in young emerging artists at his museum. "Our museums need to collect and preserve art from earlier eras, but I worry that we do that at the expense of the art of today. There's always this emphasis on not losing our heritage, but if we don't protect the heritage of today, that will be lost to tomorrow," he says with frustration.

[A few years ago] I tried to get the museum to purchase a painting by Michael Bradley [an African American artist born after 1965]. He was a real up and comer then. But, we didn't buy, and so we missed out on that opportunity. We're generally priced out now.

Myron, an aspiring Millennial collector and black museum patron, is inspired by collectors who have what he calls "a more contemporary flavor." He named the music executive and hip-hop artist Kasseem Dean (Swizz Beatz), who was born in 1978, as a model patron. Dean, who recently became a trustee at the Brooklyn Museum, collects privately and engages 
in public patronage through the No Commission Art Fair. ${ }^{6}$ Although the event focuses on global contemporary art, African American artists such as Derrick Adams, Rashaad Newsome, Ebony Patterson, and Kehinde Wiley have participated in the Bronx edition of the fair. It is younger artists like these that Myron especially enjoys seeing featured at his local African American museum, though he admits that some of the work may turn off older patrons. "For people like my grandmother, some of the newer art doesn't connect. The topics, and even the media, can be a turnoff. Like for her, painting is quote unquote 'real art.' Digital art, that's a no," he comments.

Elena, a Millennial patron, thinks that it is important for the museum she supports to emphasize contemporary art, as well as contemporary programming more broadly, to appeal to younger supporters. "You see all of these museums around the country ... incorporating DJs and having more of a nightlife feel. I think that that's one strategy that people have been using [to get younger supporters]," she says.

So we [she and other younger supporters at her museum] envision a gallery space as a multi-use space. Bringing in cultural producers and curators of our generation to organize programming has been the most effective way, whether that's an exhibition featuring contemporary artists of our generation, and then hosting a VIP reception, or having some sort of roundtable discussion about issues affecting our community hosted by the institution.

I ask what she thinks about featuring work by older African American artists, such as Jacob Lawrence, Romare Bearden, and Elizabeth Catlett, at the museum. "I think there's, of course, respect and admiration for those artists," she replies.

And certainly, the contemporary artists who are working today are deeply inspired and influenced by those artists. I just think that, not to say that time moves linearly at all, but we're in a different social [context]. ... So, the art is just different. ... So, that's why I say that having the focus on contemporary artists matters. I think young people are looking for safe spaces. And I know that word, that phrase, is sort of contrived and used a lot. But, I think it's true, and I think ... black institutions in particular ... serve as a space where community can be celebrated, and artists who are thinking through issues, can have a platform.... So, that's why I say we need contemporary artists and to create programming and events around [them].

A Millennial patron who lives close to the museum where he is a member of a support group also emphasizes how exhibitions, as well as events, should focus on contemporary culture. A museum event that featured a Millennial hip-hop artist was especially meaningful to him because it was "socially 
relevant." "I'd say that as long as the art or the artist is relatable somehow, then it's a draw," he explains.

Whereas some younger supporters question the relatability of artists who emerged in earlier periods, it is these artists who appeal most to Cheryl, an older supporter. It is her contemporaries, artists who like her were young adults in the 1960s and 1970s, whom she takes a special interest in. These are the artists, some of whom she began friendships with decades ago, whose work she collects. "None of them are famous," she says. It is for precisely this reason that she believes that they deserve the attention of African American museums. "I have [artist] friends who have been working for years and years-no museums have bought or shown their work." "Maybe one day," she muses. "Everything old is new again, right?"

A supporter in her 60s also observes that older African American artists have been especially neglected in the art world. "If you look at who is making it, who is hot, it is Basquiat, it is Kara Walker, Lorna Simpson, Glenn Ligon." These artists, she points out, were born in the 1960s. "I want to see shows of artists, especially black women artists, who never got their big break," she says. This is the work that is displayed throughout her own home. Articulating an uplift ideology that combines elements of race, age, and generation, she comments, "I like to look out for black women artists from my era."

Older supporters are not only more typically enamored with art produced in earlier periods, but they are also more likely to want "oldies, but goodies" songs played at museum events. "There's a level of sophistication as you get older," a baby boomer explains.

I went to a [museum] function and there were all older people there. I thought I'd see some young people, but Funkadelic was playing. ... You've got to be [older] to know Funkadelic. ... Unless you're going to have P-Diddy, it's hard to ... bring young people in.

In her view, generational differences in the music patrons want to listen to at museum events are partly a function of life cycle-she feels that as one gets older, one's tastes become more "sophisticated." However, she also notes that taste differences are a function of generational exposure. The band Funkadelic was popular in the 1970s, before Millennials and some Gen-Xers were even born. Their music is part of the soundtrack of her generation, not of those who came later.

Jennifer, an Older Boomer patron, describes how her tastes differ from those of her daughter Emily, a younger member of Gen X. When a DJ spins music like the funk band Parliament's 1977 hit "Flashlight," Jennifer is one of the first to hit the dance floor at events like her local black museum's fundraising gala. She sways to the beat and mouths the words. Emily has a similar reaction when she hears the opening beat to songs like "Juicy," the 1994 hit by the Notorious B.I.G. "It was all a dream," she'll sing along to 
the first verse. The ideal playlist at a museum gala varies somewhat for this mother and daughter duo. Both would prefer a journey through time that features African American music from different eras, but where they would pause varies. Gina would prefer an extended moment in the 1960s and 1970s. Emily would be happier with a bit more time spent featuring music from her college and graduate school days in the 1990s. Eric, a Millennial and family friend, would concur with the general principle of featuring black music from across the eras. However, for him the perfect pause would be in the early 2000s when groups like Jagged Edge and B2K were popular. It is in 2013 that Black Lives Matter, a social movement that will arguably define his generation, emerged. Next, we will see how patrons from different generations think about the place of this social movement and other contemporary political issues in African American museums.

\section{Politics}

On August 10, 2014, a black teen named Michael Brown was fatally shot by a white police officer in Ferguson, Missouri, a suburb outside of Saint Louis. On the one-year anniversary of his death, a group of activists stood arm in arm on the steps of the Saint Louis federal courthouse. With one arm linked to the Reverend Starsky Wilson and the other raised to the sky, Rahiel Tesfamariam, a Millennial writer, theologian, and activist, prepared to march downtown. This protest stands within a long tradition of black civil rights activism. But, the white words emblazoned on Tesfamariam's black sleeveless t-shirt signal a break from the past: "This Ain't Yo Mama's Civil Rights Movement" (see Figure 5.2). When the National Museum of African American History and Culture opened in the following year, the t-shirt was among a small group of artifacts, such as protest banners and placards, linked to activism around Brown's killing. Tesfamariam donated the t-shirt to help ensure that this new phase of black resistance was documented in the museum (McGlone 2016)(see Figure 5.3).

Tesfamariam's black museum patronage is illustrative of the distinct political orientation of younger generation supporters. In comparison to older supporters, Millennials and Gen-Xers typically place more emphasis on African American museums as spaces to commemorate and engage in civic dialogue around contemporary political struggles. In contrast, older supporters tend to lay more stress on black museums as institutions to preserve and engage political movements and issues from decades long past. As the sociologist Andreana Clay (2012) theorizes, the political struggles facing the post-civil rights generations vary from those of their parents and grandparents. Whereas the latter spent all or a good part of their formative years in a nation marked by state-sanctioned racial segregation and discrimination, the former were born into a nation gripped by racial inequality of a new kind. With the passage of civil rights laws banning racial discrimination, African Americans born in the mid-1960s and later were ostensibly 


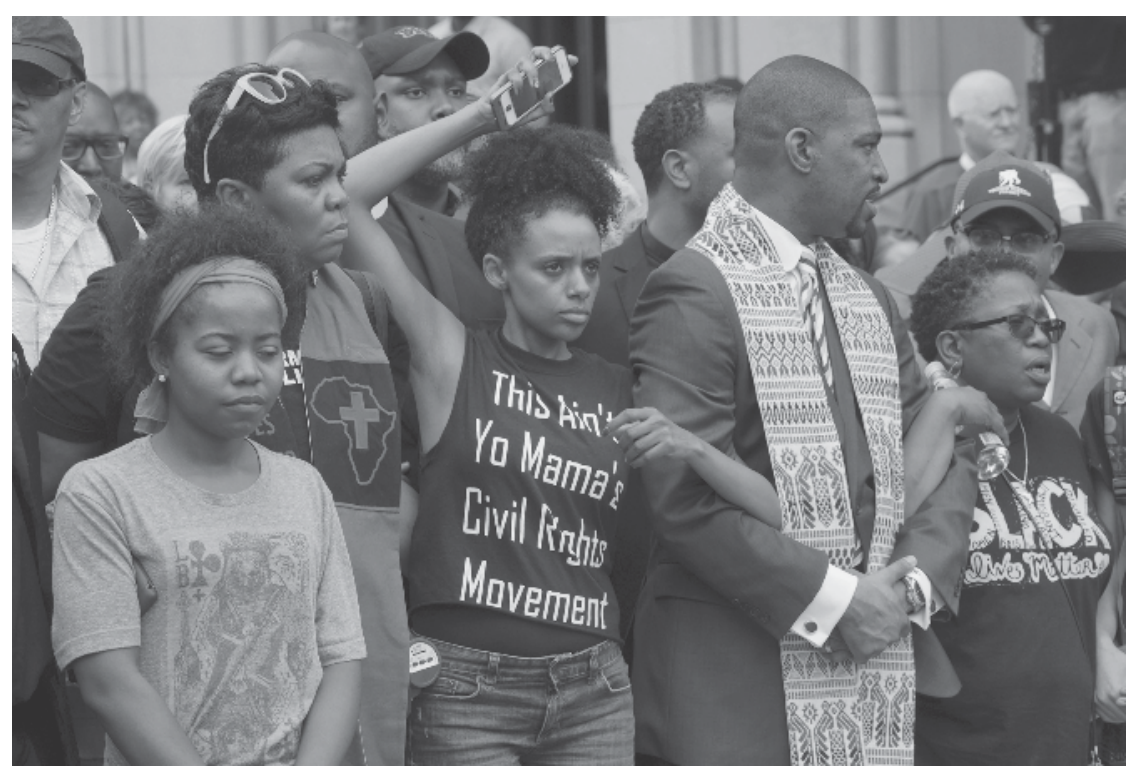

Figure 5.2 Protesters prepare to march in downtown St. Louis (Rahiel Tesfamariam, center, wearing a "This Ain't Yo Mama's Civil Rights Movement” t-shirt later donated to the National Museum of African American History and Culture). Rick Wilking.

born free. But, as Clay argues, racial inequality took on a new shape in this post-civil rights era. Unequal schooling, racial profiling, mass incarceration, and other forms of inequality thrive in this age. The sociologists Lawrence Bobo, James R. Kluegel, and Ryan A. Smith (1997) contend that racism in the post-civil rights era has shifted from Jim Crow to laissez-faire. Systematic racial inequality still exists, but it is justified on the grounds of cultural rather than biological inferiority. Or, "blacks are still stereotyped and blamed as the architects of their own disadvantaged status." The sociologist Eduardo Bonilla-Silva (2010) coined the term "color-blind racism" to describe the new ideology that justifies stark racial inequalities in the post-civil rights era.

Thus, while both older and younger supporters born in the United States came of age in a nation where race influenced opportunities, how race shaped life chances shifted. These variant generational experiences of inequality inform how supporters think about which political struggles should be highlighted in African American museums. For the older generation, who directly experienced de jure segregation and other legal forms of racial inequality on either side of the color line, artifacts and narratives from those eras often take on heightened significance. Similarly, members of a generation that personally fought for or at least observed in real time the 


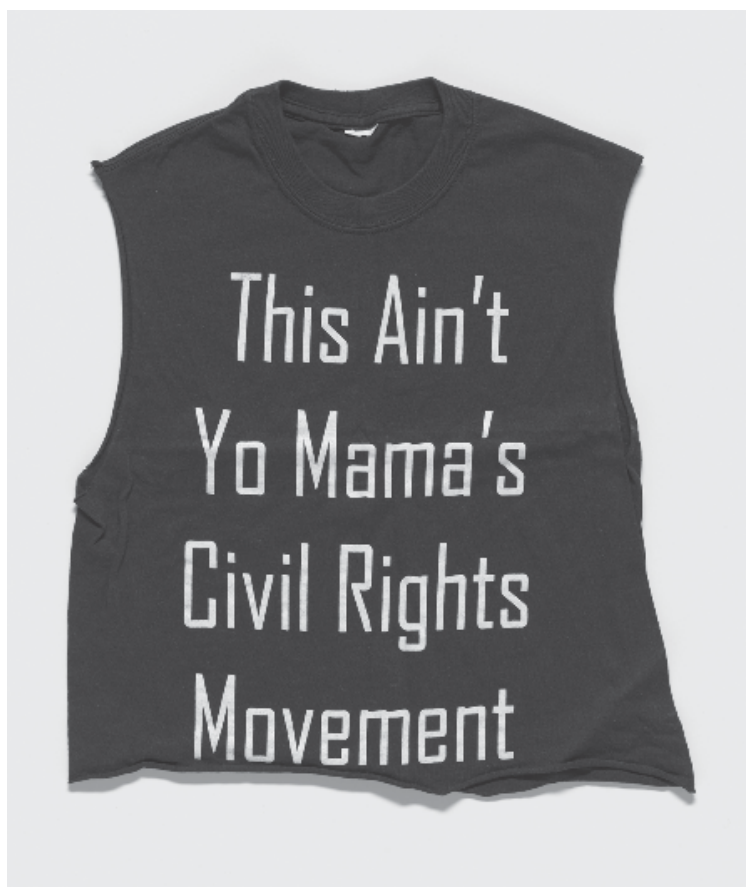

Figure 5.3 “This Ain't Yo Mama's Civil Rights Movement” t-shirt worn by Rahiel Tesfamariam at a protest commemorating Michael Brown. Collection of the Smithsonian National Museum of African American History and Culture, Gift of Rahiel Tesfamariam.

struggle to end state-sanctioned racism believe that commemorating the civil rights movement in African American museums is particularly meaningful (see Figure 5.4). To be sure, it is not that older supporters are indifferent to African American museums as spaces to address contemporary inequality, or that younger generational supporters see little relevance in commemorating past inequalities in these institutions. Rather, it is not uncommon for there to be generational differences in the degree to which past or present political struggles capture the hearts and minds of supporters form different age cohorts.

Artifacts telling the story of Brown's death are not the only evidence of the new civil rights struggles at the NMAAHC. On September 16, 2016, when historical images were projected onto the façade of the building, an image from a Black Lives Matter rally wrapped around its four sides. In the image, protestors march along a city street holding a black-and-white BLM banner. Other African American museums are also engaged with the racial activism of today. For example, the theme of the 2017 Association of African American Museums conference was Presence-Power-Persistence: Advancing 


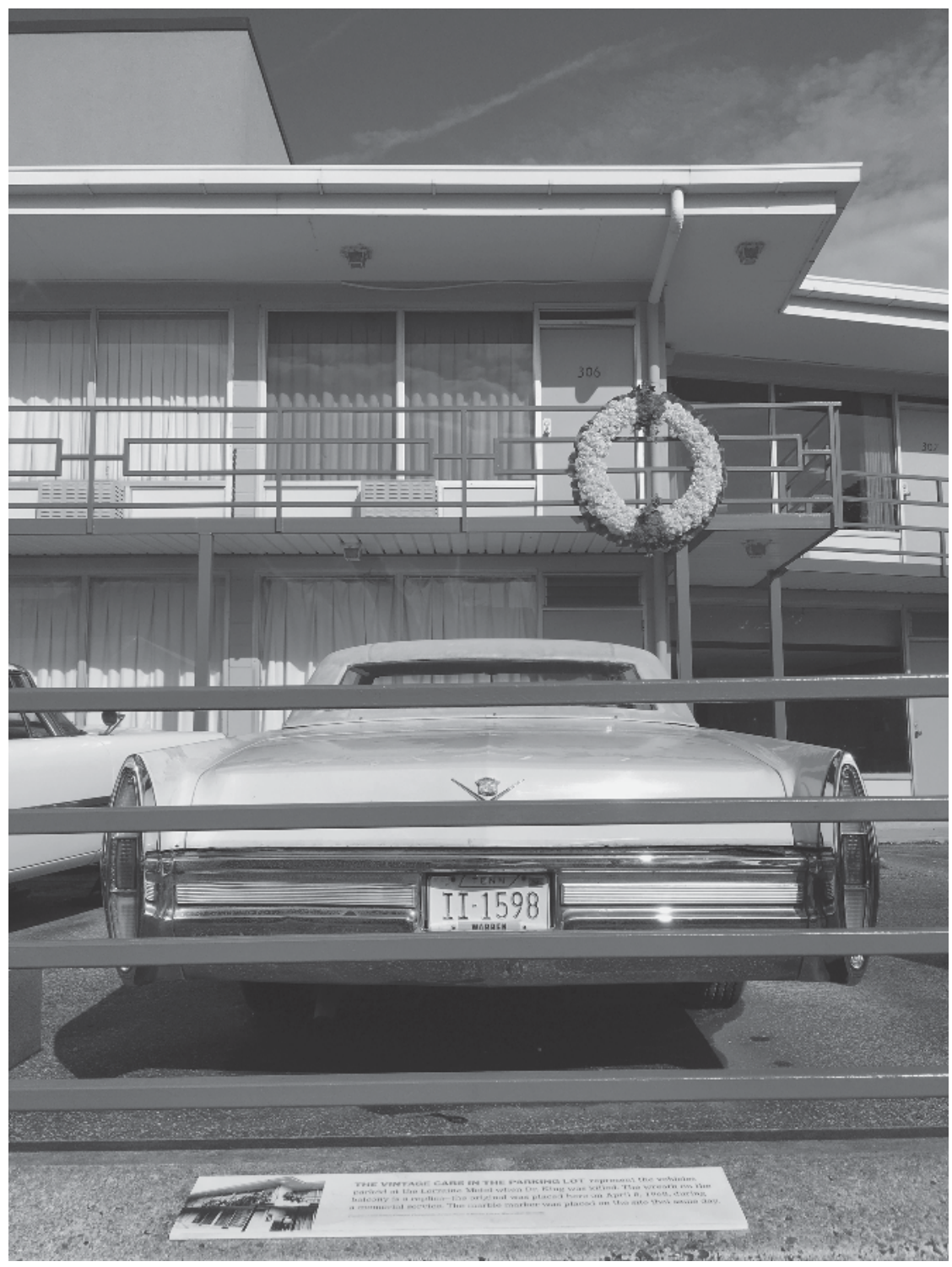

Figure 5.4 Site of the assassination of Martin Luther King Jr., Lorraine Motel, National Civil Rights Museum, Memphis, Tennessee.

the History and Possibility of Museum Activism. Conference-goers attended sessions such as "Who Will Survive America? A Conversation on Black Museums and Social Activism in the 21st Century" and "MLK50-Where Do We Go From Here? A Roundtable Discussion on Commemorating Dr. King's Legacy and Inspiring Social Activism.” 
In the words of one black Millennial patron, engagement with contemporary racial activism is critical for appealing to the "woke" crowd of young adults for whom awareness and critique of today's racial inequalities is a central part of their identity. She notes that the prototypical woke Millennial uses social media to share and comment about the latest police shootings and other racial incidents. For such woke museum patrons, there can be an expectation that African American museums are part of the broader online and offline information network that distributes information and comments about these incidents. One Millennial supporter is disappointed in the absence of such direct involvement by her museum. As the wave of BLM protests has swept the nation and her local community, the museum's social media accounts have been "almost radio silent" about the marches. From her perspective the museum "should be at the center" of the contemporary movement to end racial inequality. "The least of that is participating in the social media conversation," she argues. She believes that African American museums should serve as what Duncan F. Cameron (1972), a former director of the Brooklyn Museum, describes as a "forum." Cameron contrasts the museum as "temple," where objects and ideas representing the status quo are presented for patrons to passively accept, to the museum as "forum," a space of civic and aesthetic debate. Although this patron does not view her museum as actively supporting the racial status quo, she views its silence on social media about contemporary racial incidents as a lost chance to fulfill its role as a forum.

Other younger patrons are also directly involved in racial activism in their cities. One supporter who has participated in recent racial justice rallies sees this period as the most important historical moment in the movement for racial equality since the 1960s and 1970s. "This is the new civil rights movement," she says. The day after I arrived in one city, a BLM march shut down some major thoroughfares. Though the protest was ultimately peaceful, there were tense moments when it appeared that a violent confrontation might take place between the police and activists. The night before, I was sitting in a city park listening to a local singer perform in a free concert, when a black woman in her late 20 s struck up a conversation with me. She was a home nursing aide and was planning to participate in the march the following day. In her view, the march was necessary on account of continuing racism in the city. She was frustrated by a recent run-in between her boyfriend and local police, as well as what she saw as disrespectful treatment from some of her white patients.

While a class divide exists between this woman and the Millennial black museum supporters whom I interviewed, several shared her view that racial discrimination and stigmatization continue to be defining social problems that BLM can help to remedy. For example, when I ask one Millennial if he has been to any BLM marches, he says, "Oh yeah, plenty."

I've been to protests. I have friends who have been to protests and organized protests. I was having a conversation with a friend who is an 


\section{A new generation}

educator, and she was just like, "Should I go to this protest?" She kind of felt bad because she wasn't able to go for whatever reason. I told her, "You're an administrator [in education]. You can protest there too. You can protest anywhere." I feel like that's the next step of the movementpeople finding ways to incorporate protesting in what they are doing specifically. If you work in health care, you are going to protest there. If you work in education, you protest there. If you're an organizer and you actually want to be in the street protesting, that's fine. But, I don't feel like everybody has to be in that space.

He agrees that black museums can be a good venue for engagement with BLM, but that their engagement can take both direct and indirect forms (see Figure 5.5). "Black Lives Matter is not monolithic, so I feel like the fundamental work that the museum does is a part of the movement for Black Lives," he says.

Just creating spaces for black people where they are safe is a crucial component to Black Lives Matter. I don't think that we all have to protest police brutality in order to be effective and work towards preservation of black lives.

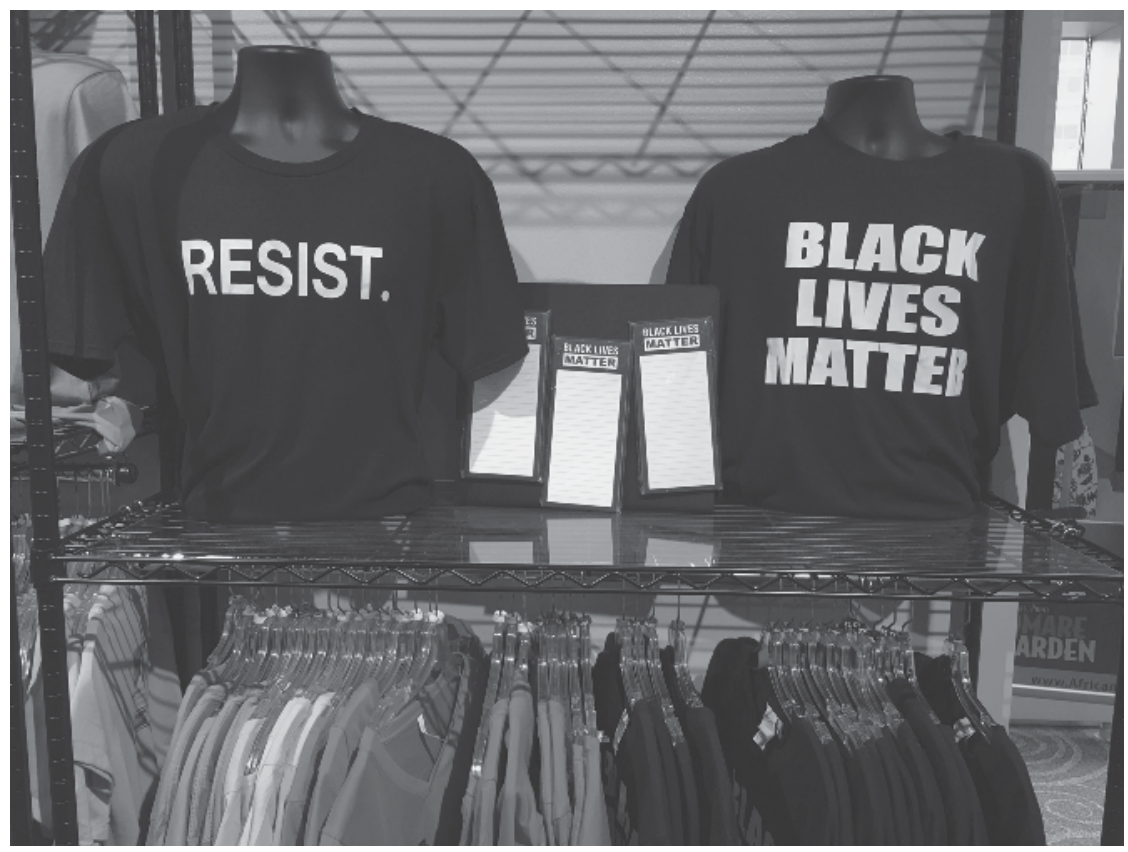

Figure 5.5 Black Lives Matter t-shirts for sale at the Reginald F. Lewis Museum of Maryland African American History and Culture, Baltimore, Maryland. 
Angie, also a Millennial, is similarly committed to BLM. "I stand for equal rights, especially for blacks. I stand for the concept behind Black Lives Matter. I stand for justice. I stand for economic stability, security, and education and healthcare," she explains. To keep her social network informed about current political events, Angie posts about them on social media. "If I see something is going on, I post on my page because there may be someone else out there who hasn't seen it yet and they're just as passionate about that particular subject as I am," she reflects. "So let's keep that information circling. Let's keep it going. Let's stay informed. Let's educate our own.” Just like churches in the 1960s were ground zero for the civil rights movement, she sees black museums as important institutions for contemporary movements for racial equality. In her view, they can be consciousness-raising sites for younger members of the community. While she believes that museum events for Millennials need to "still keep that party aspect," having fun is not enough to keep them engaged. "A lot of us are just at that point where it [partying] is not all we want to do anymore. It's still very important that we have that educational piece," she explains. At the museum that she supports she has helped to organize events for younger supporters that fulfill their desire for education and dialogue around current events.

Throughout the year we have conversations, discussions, and events to keep people informed. Last term we had three Black Lives Matter events. [The last] was well attended, a packed house. People were standing and did not care that they were standing for over an hour because the topic was that important.

Rosa, a Millennial, is also involved in BLM. "I go to the marches," she says.

I've been involved [in BLM], and I'm actually taking this year to change the ways that I am involved with local level leadership and community organizing work. It's something that I want to be realistic with. How much can I offer? Which pieces of the movement matter most for me?

She notes that though the museum she supports has not been directly involved in BLM, she does feel that is an appropriate venue to address the movement. "We haven't done anything explicitly, but I feel like we're one entity who is capable of being able to have that conversation," she says.

Younger supporters, particularly Millennials, are more likely to be directly involved with or have close friends who are tied to current political movements such as Black Lives Matter. It is not uncommon for them to support the prospect of black museums serving as a space to directly engage the movement via collecting and exhibiting objects or facilitating public discussions. As we will see, to a degree, this is a contrast to some older supporters' attitudes. Older supporters are less likely to be personally involved with movements 
like BLM and to have friends and acquaintances who are linked to it. They are also more likely to express hesitancy about direct involvement of black museums in the movement. It is also more common for them to see the appropriate place for BLM in black museums as one where it is contextualized within the earlier, and often idealized, civil rights movement.

Tim, an older white supporter, lives in the same city as the black home nursing aide I talked with at the outdoor concert. But, while she was born in the post-civil rights era, he came of age during the Jim Crow era. He has not walked in any local BLM marches or traded comments and photos about them on social media. He saw clips about the most recent protest on the local evening news. "I was relieved that there was no violence," he recounts. "Can the museum [the black museum where is a trustee] help end the tension in the city?" I ask. "I hope so," he replies. During our interview, Tim talks with passion and great detail about racial injustice in the city. Yet, unlike the home nursing aide, his narrative about race in the city covers legalized segregation and civil rights marches years before. For him, BLM is one development in a decades-long march to freedom in the community. Indeed, his vision of black museums helping to address contemporary racial inequality is to educate the public about "progress that's been made over the years."

An older black supporter who lives in a different community also takes a long view of racism in his city. When I ask him about recent civil unrest, he replies, "Unfortunately, it isn't new." He gives a decade by decade run-through of political unrest in the city, including activism in response to police violence years earlier. In his view, the museum should highlight racial inequality of the past to provide a benchmark for progress made and promises unfulfilled. Learning the history of the civil rights movement can provide "teachable moments" for younger activists. He admits to having concerns about the level of organization of some of today's protests. "If you study the civil rights movement," he says, "you'll see that it was run with military discipline. Does that exist today? I'm not always so sure."

$\mathrm{He}$ is not the only member of the civil rights generation to offer a critique of social activism among the inheritors of the movement. Before the 2016 Peach Bowl in Atlanta, Georgia, football players sat in Ebenezer Baptist Church, the former church home of Martin Luther King Jr., to listen to Andrew Young, Xernona Clayton, and C.T. Vivian recount their experiences in the movement. Young contrasted what he sees as the even-tempered attitude and long-term planning of earlier activists with the shorter view and emotionally charged activists of today. Responding to incidents where BLM activists impeded traffic Young comments, "These young people got angry and not thoughtful, and that's dangerous. It's not being militant, it's being stupid" (Solomon 2016).

More typical of older patrons, Joanna, a white trustee, has not been directly involved in BLM. But she lauds the coverage of the civil rights movement at the museum she supports. In talking about it, she suggests that newer movements do not have the same level of organization as the older movement. 
I thought that I was a well-educated person, and I knew the basic outlines of the civil rights movements. But, I've acquired a much more detailed and nuanced understanding of the movement. It [being involved with the museum] has really increased my appreciation of how much thought and planning and patience went into it. ... It's very inspiring. Today's young people seem to like talking more than planning and doingOccupy Wall Street, Black Lives Matter-this sort of leaderless, spontaneous thing. When I compare it to all the great planning that went in [the civil rights movement] it just seems like it [BLM] could accomplish so much more if they would decide what their goal is and work on it. Do you know what I mean? And the same with Occupy Wall Street. That was just like an exercise in nothing. It's gone. Zero.

Despite these views, she does want the museum "involved in newer movements like Black Lives Matter." The civil rights movement can offer lessons for how to successfully move forward a progressive racial agenda. But, in her view, care has to be taken not to appear that the museum is too far on one side or the other. "I think as we move into the present, we have to be careful not to take too extreme a point of view, because I think that will completely detract from our purpose, which is to have people come together," she says. "But, I do think we want to try to educate people that ... it [racial inequality] is not past, that it's not even close to past, and that we've got a lot of work to do."

Jeff, a white boomer trustee, also emphasizes how learning about past racism can be a useful educational tool for addressing contemporary racial inequality. "I think in some respects it's hard to fully appreciate some of the current issues without having a better understanding of what the past issues are. By the same token, being aware of past issues makes you more sensitive and aware too of what some of the current problems might become if they're not dealt with," he reflects. When I ask him if the museum that he supports should address BLM, he hesitates and says, "I don't know. I think that's kind of a difficult issue." He concludes that if the museum does address the movement, it has to be positioned in a way that says,

"Hey, let's bring some people together to talk about points of view, perspectives." That way we can act upon what needs to be acted upon in a way that's beneficial to everybody instead of having one group here doing something and another group over there doing something, and the two not really understanding each other but thinking they know each other and in the process maybe marginalizing or demonizing one another.

If not addressed with care, he warns, forums on BLM could "become adversarial instead of collaborative, and instead of maybe dealing with issues, you make new issues that maybe are worse than some of the ones 
you're trying to deal with." Emily, a white trustee in her early 60 s, also has mixed feelings about BLM and the museum that she supports becoming directly involved with it. She's pleased that a recent march did not end in violence, but says, "I sit on pins and needles every day thinking that can change in a second."

So I'm very torn, because I get that maybe you can't be totally orderly. A lot of people don't get this. When I think back to the [civil rights] movement, you have to bring some sort of recognition to people, and sometimes it takes a jolt. But on the other hand, I just don't want it to erupt. I think this city's racial relations are fragile at best.

An older trustee who is black is also hesitant for the museum that he supports to get involved in newer political movements. However, consistent with many supporters in his age cohort, he is very supportive of its focus on the civil rights movement. "What do you think about ... what's going on now with Black Lives Matter?" I ask him. "Do you see the museum playing a role in that, or do you think it should play a role at all?" "Well, right now our museum is in a little bit of a transition," he replies.

I think we have enough business to concern ourselves with on an institutional basis, with looking after the well-being of the assets that we are trying to husband and make available. As a board, we are more concentrated on what we're going to do [about the expansion], and how we're going to [raise funds] than we are on taking advocacy positions. And I think, literally, we are not an advocacy organization. We are a history organization. We are not the ACLU. We are not the NAACP. We're not a group that says, "We're here to let you know that there's a problem and that you need to do something about it." Not that we are not willing to shed light on a problem to make it possible for you to understand the implications of some activities. Clearly, if you were to look at the programming that the museum makes available, the speakers that come and the exhibits that are on view, they do address the issues of the day. They don't address them 24/7. ... Exhibits and the like, and even a speaker series, are in the nature of long-term investments. You don't just have somebody speak on Black Lives because it came up last week.

The reticence of some older patrons to highlight contemporary movements like BLM at black museums may be not only a function of the fact that they are less connected to the movement in their personal lives-less likely to attend or to have friends or acquaintances who attend marches, less likely to be engaged with the movement via social media, etc. - but also related to the role that they play at their museums. In contrast to younger patrons who are more often members of support groups, older supporters are more likely to serve as board members. Trustees and support group members play different 
roles in museums. The role of a member of a young professionals support group is typically to give money and attend or help plan events. Trustees are also expected to give money (though more often larger amounts), but their role also entails governance. Trustees oversee a museum's strategic planning, operations, and fundraising. The now respectable civil rights movement may be more palatable to older patrons than the controversial BLM movement because of this role. With direct responsibility for governance and protecting the long-term financial interests of black museums, older supporters may be especially sensitive to the possibility that too much direct involvement in BLM could put their museums at greater risk of alienating funders and generating bad publicity and a backlash.

\section{Conclusion}

This chapter investigates how older and younger supporters value African American museums. I find that supporters born after 1965 tend to place more importance on African American museums being engaged with social media and other new technologies; showcasing hip hop culture and contemporary visual culture from more recent decades; and being engaged with political issues emergent in the contemporary era such as BLM. I attribute these variances to the greater exposure that younger supporters have had to culture, politics, and technologies that became prominent in the $1990 \mathrm{~s}$ and 2000s. Other factors, such as the variant patron roles that supporters in different stages of the life course typically take on-such as older patrons' greater likelihood of serving as trustees-may also contribute to these differences.

These findings have important implications for our understanding of museums and the contemporary. Historically, there has been tension about whether or not contemporary artifacts and art should be collected and exhibited by museums. If museums are to be places that present and interpret cultural objects that have withstood the long test of time, then the most recent art and artifacts should not find a home in them. However, museums are increasingly rejecting this orthodoxy and presenting art and artifacts that came into being in the contemporary moment (Altshuler 2005; Rhys and Baveystock 2014). This chapter illustrates how this tension between the old and the new manifests itself in African American museums. The degree to which patrons envision African American museums as institutions that should legitimize the past or turn attention to the present is partly related to their age cohort. It is the members of the youngest generations who are most taken with the idea of African American museums as contemporary spaces. Today, the youngest supporters are Millennials and Gen-Xers, but tomorrow they will be from Generation $\mathrm{Z}$ and the cohorts born after them. We might expect that Millennials and Gen-Xers will continue to place relatively high value on the cultural forms, politics, and technologies that define their generation. Yet, 25 years from now, those will no longer be new. 
Instead, featuring ' 90 s rap and BLM in museums might be rather traditional propositions. $^{7}$

By illustrating how the post-1965 generations' orientation towards hip hop culture extends into the world of high culture, this chapter also contributes to debates about urban culture and cultural capital. While hiphop culture is often rendered as at odds with high culture, here we see how younger supporters view the two as compatible. Their approach to cultural philanthropy blurs the boundaries between black popular and black high culture. Some cultural explanations of inequality argue that it is the norms and behaviors of poor people—or, a "culture of poverty" - that make and keep them poor (Lewis 1966). Hip hop, in particular, is cast as one element of the "urban" culture that is blamed for the blocked mobility of the black "underclass." Listening to hip-hop music, and emulating the hip hop lifestyle, is why, according to some, black urban youth are caught in an unending cycle of poverty (Quinn 2010). ${ }^{8}$ This chapter complicates the view that engagement with hip-hop culture fuels marginalization. Instead, we see how hip-hop culture is being integrated into the "high" culture world of younger members of the upper-middle and upper class.

Given that the broader sociological research on museum patronage rarely explores generational differences in museum values, this chapter offers a blueprint for more generally thinking about how younger supporters think about the worth of museums. As I discuss more fully in the final chapter, the distinct value orientation of younger supporters has important implications for museums, and diversity more broadly.

\section{Notes}

1 I define older supporters as those born before 1965, which includes members of the following groups: G.I. Generation (-1936), Silent Generation (1937-1945), Older Boomers (1946-1954), and Younger Boomers (1955-1964). Younger supporters are those born 1965 and after. This includes members of Generation X (19651976) and Millennials (1977-1992). While being born before or after 1965 is a common cutoff to denote different generations with respect to the changing racial structure in the United States, the specific cutoffs for generational groups such as Generation X and Millennials vary slightly from study to study (e.g., see Zickuhr 2010 and Fry 2018).

2 On occasion this chapter uses pseudonyms for artists.

3 In "Building Youth Participation," Betty Farrell (2008) explores generational distinctions in cultural participation through another lens-programs that encourage engagement with cultural institutions among teenagers.

4 While recent newspaper articles and other media report that cultural organizations are pursuing younger patrons because of a concern that audiences are aging (Gelles 2014), survey research offers mixed findings concerning the greying audience hypothesis. For example, in their research using Survey of Public Participation in the Arts (SPPA) data from 1982, 1992, and 2002, Paul DiMaggio and Toqir Mukhtar $(2004,177)$ find that since 1982 younger cohorts have had lower attendance rates 
at classical music concerts. Yet, participation in other cultural activities shows a different pattern. For example, museum-going rose among people aged 18 to 49 from 1982 to 1992, but then fell between 1992 and 2002. In another paper using SPPA Data, Richard Peterson and Gabriel Rossman (2008, 308) evaluate the greying audience hypothesis by exploring the median age of arts attendees at different periods of time. They find that the median age of opera, classical music, theater, musical, ballet, museum and jazz attendees has risen across time.

5 While the main generational division that I find is between those born before and after 1965, it is important to note that museum values also vary within these groups. When it comes to culture-specifically an emphasis on hip hop-Younger Boomers are often more similar to patrons born after 1965. Given that hip hop emerged during their formative years in the 1970s and 1980s, this is not surprising. Similarly, the focus on new technology and BLM is greater among Millennials than Gen X'ers. This is also not a surprise, given that the digital revolution was in full swing by the time that the former reached adolescence, whereas it was still emergent during the formative years of even the youngest Gen X'ers. Similarly, BLM did not emerge until 2013, when Gen X'ers were well into adulthood.

6 The art fair, which is sponsored by Bacardi, allows artists to sell their work and keep all of the profits for themselves. This is a contrast to typical art fairs, where gallerists take a percentage of sales. The fair debuted in Dean's hometown of the Bronx, New York, but since then has traveled to other cities across the world.

7 While I propose that the tendency of supporters born after 1965 to focus on the new is partly a function of a distinct set of generational values that should remain with them after they age, I also posit that it is related to other factors, such as their patron roles. As this cohort advances in the life cycle and more members take on the role of trustee, we might also expect them to become more sensitive to the costs of embracing contemporary political issues that have not yet become legitimized.

8 See Lacy (2007, 173-174) and Pattillo-McKoy (1999, 117-145) for discussions about the vulnerability of black middle-class youth who adopt a lifestyle associated with poor, black urban communities.

\section{References}

Altshuler, Bruce, ed. 2005. Collecting the New: Museums and Contemporary Art. Princeton, NJ: Princeton University Press.

BoardSource. 2017. Museum Board Leadership 2017: A National Report. Washington, DC: BoardSource.

Bobo, Lawrence, James R. Kluegel, and Ryan A. Smith. 1997. "Laissez-Faire Racism: The Crystallization of a Kinder, Gentler, Antiblack Ideology.” In Racial Attitudes in the 1990s, edited by Steven A. Tuch and Jack K. Martin, 15-42. Westport, CT: Praeger.

Bonilla-Silva, Eduardo. 2010. Racism Without Racists: Color-Blind Racism and the Persistence of Racial Inequality in the United States. Lanham, MD: Rowman and Littlefield.

Cameron, Duncan. 1972. “The Museum, a Temple or the Forum?” Journal of World History 14: 189-202. 
"Chance the Rapper at DuSable Museum." YouTube video, 1:29 min. Posted by Chicago Sun-Times, June 28, 2017. www.youtube.com/watch?v=n423Es0zPFU.

Clay, Andreana. 2012. The Hip-Hop Generation Fights Back: Youth, Activism and Post-Civil Rights Politics. New York, NY: New York University Press.

DiMaggio, Paul, and Toqir Mukhtar. 2004. "Arts Participation as Cultural Capital in the United States, 1982-2002, Signs of Decline?” Poetics 32: 169-194.

Eyerman, Ron, and Bryan S. Turner. 1998. "Outline of a Theory of Generations." European Journal of Social Theory 1(1): 91-106.

Farrell, Betty. 2008. "Building Youth Participation." In Entering Cultural Communities: Diversity and Change in the Nonprofit Arts, edited by Diane Grams and Betty Farrell, 114-142. New Brunswick, NJ: Rutgers University Press.

Fry, Richard. 2018. "Millennials Are the Largest Generation in the U.S. Labor Force." Pew Research Center, April 11, 2018. www.pewresearch.org/fact-tank/2018/04/ 11/millennials-largest-generation-us-labor-force/.

Gelles, David. 2014. "Wooing a New Generation of Museum Patrons.” New York Times, March 19, 2014. Accessed April 10, 2017. www.nytimes.com/2014/03/20/ arts/artsspecial/wooing-a-new-generation-of-museum-patrons.html.

Glenn, Norval D. 2003. "Distinguishing Age, Period, and Cohort Effects." In Handbook of the Life Course, edited by Jeylan T. Mortimer and Michael J. Shanahan, 465-476. Handbooks of Sociology and Social Research, Boston, MA: Springer.

Goff, Keli. 2008. Party Crashing: How the Hip-Hop Generation Declared Political Independence. New York, NY: Basic Books.

Johnson, Steve. 2017. "Chance the Rapper Joins DuSable Museum Board.” Chicago Tribune, January 6, 2017. Accessed June 10, 2017. www.chicagotribune.com/ entertainment/ct-chance-the-rapper-dusable-museum-board-20170106-column. html.

Lacy, Karyn R. 2007. Blue-Chip Black: Race, Class, and Status in the New Black Middle Class. Berkeley: University of California Press.

Lewis, Oscar. 1966. La Vida: A Puerto Rican Family in the Culture of Poverty-San Juan and New York. New York, NY: Random House.

Mannheim, Karl. 1952. “The Problem of Generations.” In Essays in the Sociology of Knowledge, edited by Karl Mannheim, 276-322. London, UK: Routledge and Kegan Paul.

McGlone, Peggy. 2016. “Before Smithsonian's Opening, Smaller African American Museums Grapple with a Behemoth in D.C." Washington Post, March 2, 2016. Accessed June 10, 2017. www.washingtonpost.com/entertainment/museums/ before-smithsonians-opens-smaller-african-american-museums-grapple-with-abehemoth-in-dc/2016/03/02/ed151ea8-d58d-11e5-be55-2cc3c1e4b76b_story. html?utm_term=.e5c84a6bd994.

Ostrower, Francie. 2013. "Diversity on Cultural Boards: Implications for Organizational Value and Impact.” Working Paper, National Endowment for the Arts, Washington, DC.

Pattillo-McCoy, Mary. 1999. Black Picket Fences: Privilege and Peril among the Black Middle Class. Chicago, IL: University of Chicago Press.

Peterson, Richard A., and Gabriel Rossman. 2008. "Classifying Quality: Cognition, Interaction, and Status Appraisal of Art Museums." In Engaging Art: The Next Great Transformation of America's Cultural Life, edited by Steven J. Tepper and Bill Ivey, 307-342. New York, NY: Routledge. 
Peterson, Richard A., Darren E. Sherkat, Judith Huggins Balfe, and Rolf Meyersohn. 1996. Age and Arts Participation, with a Focus on the Baby Boom Cohort. Washington, DC: National Endowment for the Arts.

Quinn, Eithne. 2010. Nuthin' but a “G” Thang: The Culture and Commerce of Gangsta Rap. New York, NY: Columbia University Press.

Rhys, Owain, and Zelda Baveystock. 2014. Collecting the Contemporary: A Handbook for Social History Museums. Edinburgh, UK: MuseumsEtc.

Sackmann, Reinhold, and Oliver Winkler. 2013. "Technology Generations Revisited: The Internet Generation.” Gerontechnology 11(4): 493-503.

Solomon, Jon. 2016. "Civil Rights Leader to Alabama, Washington Players: Black Lives Matter Is Too Angry.” CBS Sports, December 28, 2016. Accessed April 10, 2017. www.cbssports.com/college-football/news/civil-rights-leader-to-alabamawashington-players-black-lives-matter-is-too-angry/.

Zickuhr, Kathryn. 2010. Generations 2010. Washington, DC: Pew Research Center. 


\section{Rethinking cultural patronage in a diverse age}

In August 2017, almost a year after the NMAAHC was founded, the Association of African American Museums (AAAM) held its 39th annual conference at the new museum (see Figure 6.1). When AAAM was established in 1978, the black museum movement was in its infancy. In the ensuing decades, the field has flourished: the NMAAHC stands among a few hundred black museums and related institutions across the nation. Neither the NMAAHC nor most other African American museums would exist without private philanthropy. Money, time, expertise, and other resources from private citizens are critical for these institutions' survival and sustenance. Yet, we know very little about why patrons give to this class of museums. By systematically analyzing how patrons define the value of African American museums, Diversity and Philanthropy at African American Museum offers insight into this question. To conclude, I summarize findings and discuss the book's major contributions to scholarship on museum patronage and cultural patronage more broadly. I also offer directions for future research and sketch the practical insights that it offers for understanding museum patronage in an era where issues of diversity are increasingly prominent.

\section{Summary of findings}

Chapters 2 through 5 illustrate the multidimensionality of African American museum values; show how definitions of worth vary among different types of supporters; and consider the structural and cultural conditions that enable and constrain various values. In Chapter 2, I show how black supporters tend to pay particular attention to the significance of African American museums for blacks, while white supporters are especially sensitive to the museums' roles in the lives of whites. I also elaborate how first- and secondgeneration immigrants from Africa and the West Indies have a heightened awareness of how black museums fit into these communities. I suggest that these distinctions are enabled by cultural factors, such as patrons' varying racial and ethnic identities, and structural factors, such as their different encounters with discrimination and racial isolation. 


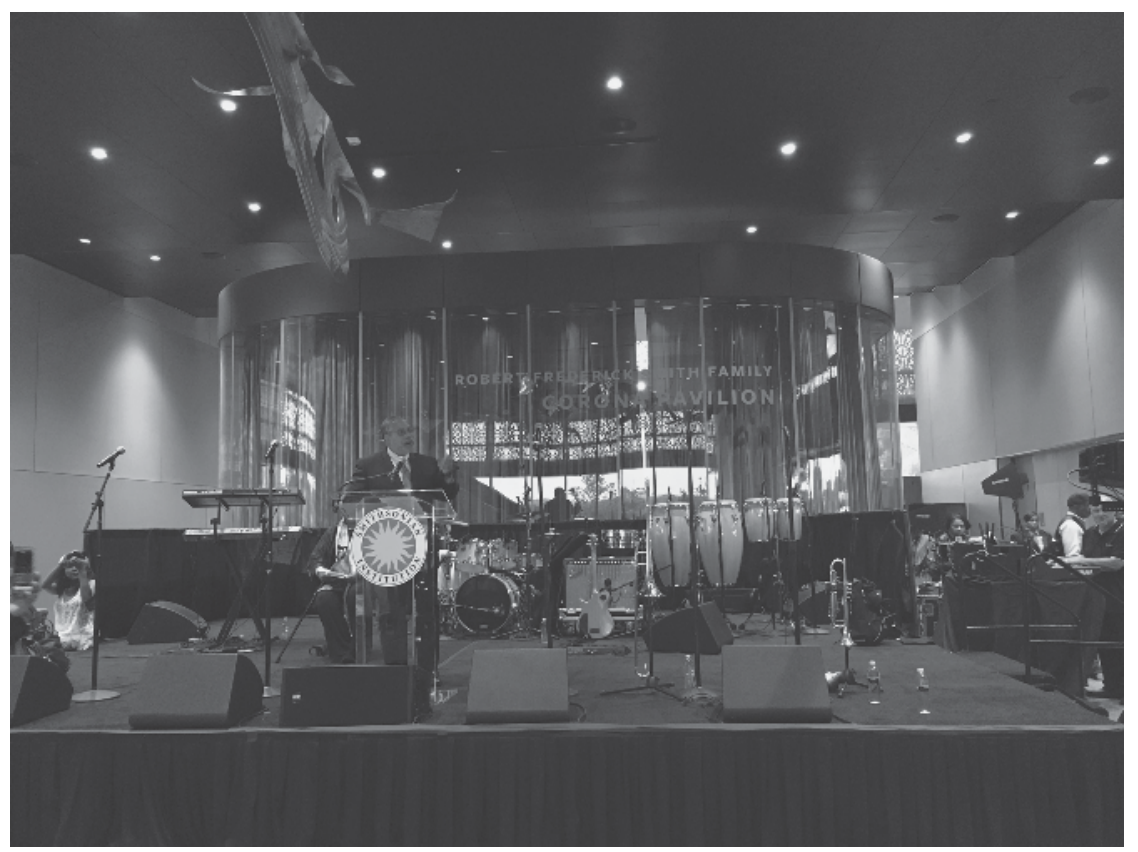

Figure 6.1 Lonnie Bunch, director of the National Museum of African American History and Culture, speaking at the Association of African American Museums annual meeting, 2017.

In Chapter 3, I elaborate how patrons' museum values vary based on profession. I show how supporters who work in the private sector, especially entrepreneurs, executives, and lawyers, more commonly value black museums as institutions that are tightly linked to their careers. For members of this group, supporting black museums is often valued as a practice that provides them with the opportunity not only to use the resources of their profession to give back, but also to advance their careers by building and nurturing professional ties. I propose that the higher emphasis placed on the career value of giving to black museums among patrons who work in the private sector is partly due to structural factors, such as the higher level of embeddedness of their workplaces in museum philanthropy and their exposure to business ideologies like the ethos of corporate social responsibility.

Chapter 4 examines the differences in how cultural connoisseurs and cultural appreciators define the value of black museums. The former, who are more involved in cultural activities, are more likely to judge black museums according to cultural criteria. In evaluating black museums, connoisseurs are highly sensitive to factors such as museums' role in valorizing black culture 
and where they stand in museum hierarchies. I suggest that connoisseurs' higher emphasis on cultural standards of evaluation is due to their greater exposure to culture in their broader lives. Chapter 5 explores how museum values vary among patrons from different age cohorts. I describe how younger patrons tend to place higher value on black museums being engaged with contemporary technology such as social media, contemporary culture like hip hop music, and contemporary political issues such as police brutality. I consider how younger patrons' higher attentiveness to whether black museums are engaged with these aspects of contemporary society is a function of their higher levels of exposure to these dimensions of life and lesser likelihood of being museum trustees.

\section{Scholarly contributions}

By examining African American museums and intraclass differences in museum values among the upper-middle and upper class, this analysis advances scholarship on cultural patronage. In particular, it offers new insights into the ways that museum patronage shapes, and is shaped by, social divisions, as well how museum patronage influences cultural boundaries. A main contribution is the complication of the conventional classcentric approach to museum patronage. Although there are a range of theories that explain museum patronage, what they typically share is a focus on class. Class theories emphasize a distinction in cultural values that falls along class lines. The middle and upper class are typically cast as appreciating museums, and the working class and poor are seen as rejecting them (Bourdieu, Darbel, and Schnapper 1991). However, here I build on the sparse scholarship demonstrating that there is not a homogeneous set of patronage values among the upper-middle and upper class.

While a fundamental contribution of the findings is the elaboration of how social boundaries other than class are implicated in museum patronage, this book also offers a more in-depth account of how class is intertwined in the practice. A common argument is that museum patronage derives its worth to the upper-middle and upper class from its capacity to nurture members' class position. For example, activities such as serving on a museum board signal membership in the elite and establish and nurture relationships within this group (DiMaggio 1982a, 1982b; Ostrower 2002). I complicate this approach by elaborating how the class value of museums to patrons depends on their other identities. For example, Chapter 2 sheds light on how some black patrons are especially sensitive to the significance of giving to black museums for strengthening cohesiveness among the black middle and upper class, and Chapter 4 illustrates how some private-sector supporters place special emphasis on the value of giving to black museums for career outcomes. Similarly, while I find evidence that some patrons have a desire for other members of their class to become involved in the black museums that they support, I also find that the specific segments of their class that they 
want to recruit vary. To return to the examples above, some black patrons are especially keen on ensuring that other members of the black middle and upper class participate in the leadership of African American museums, and some corporate patrons see other members of their firms as ideal prospects to succeed them on boards.

By elaborating the different ways that patrons understand the class value of museums, this book also offers more nuance of the argument that the upper-middle and upper class use cultural patronage to protect their class interests. Patrons' views about how museums should be governed and the directions that they need to move in are not uniform. For example, all patrons do not place the same value on black leadership and social media engagement at black museums. Instead, it is black patrons and younger patrons, respectively, who are typically most concerned about these issues. By highlighting the heterogeneous, and sometimes competing values of patrons, findings complicate the view that a unified set of upper-middle- and upper-class interests are pursued by trustees and others involved in museum governance.

In a related vein, the analysis presented here complicates the view that the upper-middle and upper class use patronage to protect their class interests by offering insight on how they value policies and practices that are actually inclusive in nature. In her research on cultural patronage, Ostrower (1999) argues that while trustees support limiting board seats to the extremely wealthy, they also favor some policies that are democratizing. My findings further elaborate some of the inclusive values of museum patrons. Here, in the context of black museums, we see how some patrons are concerned with issues such as museums hiring black staff and addressing current social problems.

Another common, and related, argument in research on museum patronage is that the middle and upper class find worth in museums for cultural reasons (Bourdieu, Darbel, and Schnapper 1991). This approach assumes that members of the middle and upper class have a deep appreciation for, and understanding of, culture, which compels them to become engaged with museums. In her research on trusteeship at majority museums and opera houses Ostrower $(1999,2003)$ critiques the love of art thesis. This book empirically extends the critique by elaborating it within the context of patronage at black cultural institutions. Here, we see that a focus on the cultural value of black museums is not shared equally among uppermiddle and upper-class patrons. Instead, it varies by lifestyle and is strongest among connoisseurs.

This book also advances the scholarship on race and museum engagement. There is a growing body of findings showing differences in rates of museumgoing across racial and ethnic groups and differences in the meanings that visitors from various racial and ethnic groups attach to museums (DiMaggio and Ostrower 1987, 1990; Scott 2008). ${ }^{1}$ However, we still know very little about how philanthropists from various racial and ethnic groups think 
about the value of museums. Ostrower's (2002, 48-52) finding that some black trustees on majority museum boards think about their patronage in relationship to their racial identity is among the important exceptions. This line of inquiry is furthered here not only by analyzing black museums but also by elaborating how, relative to whites, black supporters place particular emphasis on the significance of these institutions for the black community. Our understanding of race, ethnicity, and cultural patronage is also advanced here by examining intragroup differences in museum values among black patrons. Most explicitly, this is addressed in Chapter 2, which compares how first- and second-generation black supporters from Africa and the West Indies place more emphasis on the value of black museums for these communities. For example, we see how bilingualism in black museums is a special concern for some black patrons with these backgrounds. Given that between 1980 and 2017 there was a 71 percent rise in the number of black immigrants living in the United States, understanding how their museum values vary from native blacks is especially important (Anderson and López 2018).

By elaborating how race and ethnicity organize the museum values of white patrons, we also gain a more in-depth understanding of racial and ethnic boundaries and cultural institutions. Though there is a long-standing literature on museum patronage among middle- and upper-class whites, it is their class not race that is given prominence in understanding their support. I depart from this conventional approach by addressing how the race of white museum patrons figures into their support. In the context of black museums, we see how white patrons are often self-conscious about their race and place special emphasis on the value of black museums for bridging racial communities. We also see instances where their ethnicity is salient. For example, in Chapter 2 we see ethnicity come into play in the narratives that white patrons emphasize in black museums.

My findings also advance the study of museum patronage by addressing generational differences in patronage. Although the scholarship on museum patronage notes the disproportionate involvement of older individuals among supporters (Ostrower 2013), it has largely neglected generational differences in museum values. Bringing together the sociological scholarship on generations with the scholarship on cultural patronage, I elaborate how younger patrons place more emphasis on the contemporary. We see that generational tensions around technology, politics, and culture are manifest within the context of museum patronage. Given that at least some of these cohort differences may be related to generational value orientations that are relatively static across age, it is possible that as cohort replacement takes place museum boards will be governed in new ways. Insights about generational differences in museum values also contribute to knowledge about culture and urban poverty. Engagement with urban minority culture, including hip hop, is cast as contributing to blocked class mobility (Quinn 2010). However, younger patrons' advocacy for hip-hop culture in 
African American museums complicates the portrait of black urban culture as incompatible with upper-middle- and upper-class life.

Finally, my findings also advance the scholarship on museum patronage by offering new perspective on the role of museums in the aesthetic mobility of culture. In his research on the history of cultural patronage, Paul DiMaggio (1982a, 1982b) argues that through their efforts to found museums and other cultural organizations in the mid-19th century, Bostonian elites provided the institutional foundations to draw a distinction between high and popular culture. By supporting the structural and symbolic separation of some forms of culture in venerated cultural institutions, patrons nurtured a distinction between fine art and popular culture. Through analyzing black museums, we gain new insight into the links between patronage, museums, and cultural legitimization. In Chapter 3 , we see that connoisseurs place special importance on black museums taking on the task of sorting black history and culture by identifying that which is "the best."

\section{Research agenda}

While findings shed new light on important dimensions of diversity and museum patronage, they also open up new questions. Here, I offer an overview of directions for future research. First, the racial and ethnic profiles of the middle and upper class are changing. For example, since the 1950s racial and ethnic diversity among the "power elite," such as Fortune 500 CEOs and corporate board members, has increased (Zweigenhaft and Domhoff 2011, 2018). Also, by some measures, the class status of Asians in the United States surpasses whites. ${ }^{2}$ Although as a whole, class outcomes for Latinxs, such as those that are related to education and income, are below those of non-Latinx whites by a moderate to large gap, there is wide variation among Latinxs. ${ }^{3}$ The shifting racial and ethnic profiles of the middle and upper classes, along with the finding in this study that museum values vary across different racial and ethnic groups, mean that it is increasingly imperative to undertake research on the museum patronage of racial and ethnic minorities such as Latinxs and Asian Americans.

It is not only growing numbers of prosperous racial and ethnic minorities that make further study of diversity and museum patronage important, but also the growth of ethnic museums. Just as the black museum movement began in the 1960s and 1970s, there has also been growth in ethnic museums more broadly since this time (Abrams 2004; Ardali 1989; Council of American Jewish Museums n.d.; Loukaitou-Sideris and Grodach 2004; Matlon, Van Haastrecht, and Mengüç 2014; National Endowment for the Arts 1992). ${ }^{4}$ In the 1960s, ethnic museums such as El Museo del Barrio in New York City and the Wing Luke Museum of the Asian Pacific American Experience in Seattle, Washington, were founded. The tribal museum movement centered around Native American culture and history was also born in the 1970s. By 2003, depending on how they are defined, there were between 110 and 236 
tribal museums in the United States (Abrams 2004, 3; Cooper and Sandoval 2006, 8). Similarly, when the Council of Jewish Museums was established in 1970 , there were seven members. Since that time the number has swelled to 80 (Council of American Jewish Museums n.d.).

The late 20th and early 21st centuries marked an especially notable period for ethnic museums in Washington, DC. Not only was the legislation for the NMAAHC signed, but the Arthur M. Sackler Gallery, an Asian art museum, the Asian Pacific American Center, and the National Museum of the American Indian opened between 1987 and 2004 at the Smithsonian. The United States Holocaust Museum, which is adjacent to the National Mall, opened in 1993. In 1987, the Smithsonian Latino Center opened, and in 2003 legislation was passed to create the Commission to Study the Potential Creation of the National Museum of the American Latino (Dávila 2012). Although there is still no federal legislative commitment to build such a museum, if it is established there will be a major fundraising campaign. The commission's final report projected that $\$ 300$ million would need to be raised from the private sector over the course of a decade to build the museum (National Museum of the American Latino Commission 2011). In 2017, congressional legislation was introduced to establish not only the National Museum of the American Latino (H.R. 29112017 and S. 1364 2017), but also the National Museum of Asian Pacific American History and Culture (H.R. 868 2017). Growth in museums associated with racial and ethnic minorities means that it is critical to examine how members of the upper-middle and upper class from across the racial and ethnic spectrum define their value. For example, we need to know more about how not only Latinxs but also whites and African Americans understand the value of Latinx museums.

The issues raised in Diversity and Philanthropy at African American Museums have relevance not only for museums in the United States but also for those in other parts of the world. In recent decades, notable museums focused on the culture and history of people from the African diaspora have opened across the globe. For example, in England the International Slavery Museum opened in Liverpool in 2007, and the Black Cultural Archives in London, originally founded in 1981, reopened in a new building in 2014. In recent years, Africa has seen the establishment of museums such as the Mohammed VI Museum of Modern and Contemporary Art, which opened in Rabat, Morocco, in 2014 and the Zeitz Museum of Contemporary Art Africa (Zeitz MoCAA), which opened in Cape Town, South Africa, in 2016. After apartheid ended, other museums such as the Robben Island Museum, Mandela House, the Apartheid Museum, and the Hector Pieterson Memorial and Museum also opened in South Africa. In Giza, the Grand Egyptian Museum is scheduled to open in 2019, and there are plans to open two museums dedicated to the slave trade in Benin. ${ }^{5}$ Since the 1970s in Canada, museums focused on black Canadians, such as the Amherstburg Freedom Museum, Black Cultural Centre for Nova Scotia, and Buxton National Historic Site and Museum, have opened (see Figures 6.2-6.4). ${ }^{6}$ 


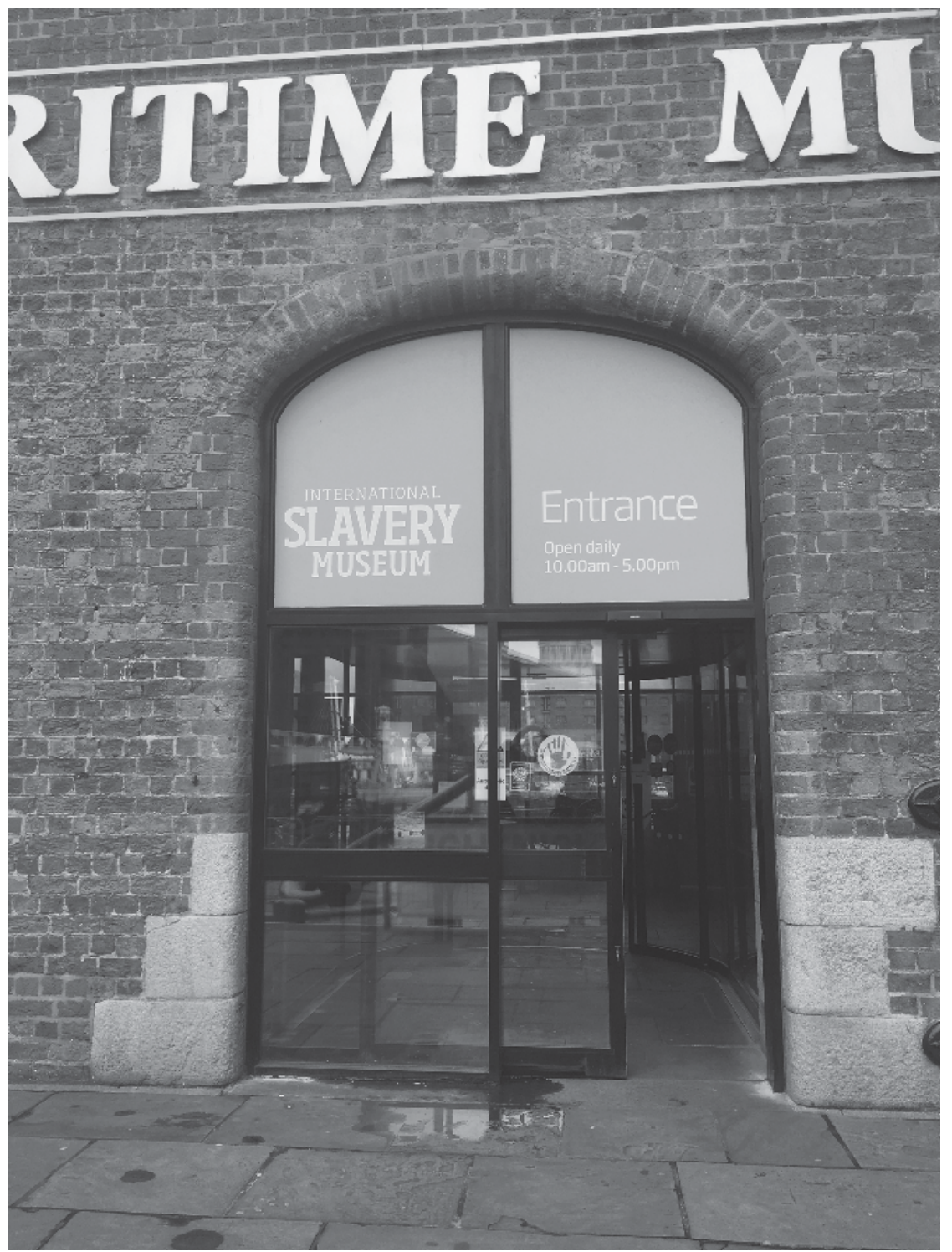

Figure 6.2 Entrance to the International Slavery Museum, London, England.

Given that there are museums across the globe focused on the history and culture of people from the African diaspora, cross-national research of museum values is an important area for future inquiry. The rich comparative scholarship examining values across different national contexts suggests that museums values would also not be static across the globe. This broader 


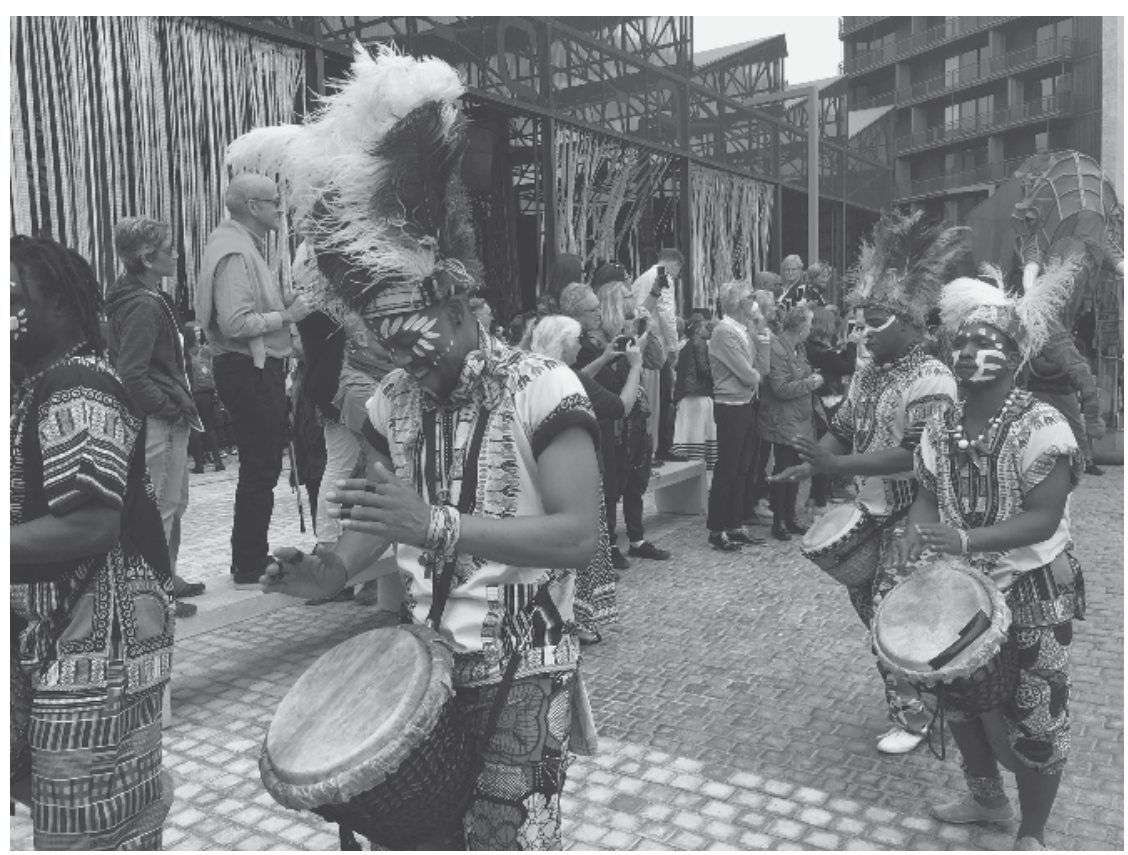

Figure 6.3 Opening of the Zeitz Museum of Contemporary Art Africa, Cape Town, South Africa.

cross-national literature on values shows how structural factors, such as the degree of racial and ethnic diversity in a country, and cultural factors, such as national ideologies about equality, shape how residents assess worth (Lamont and Thévenot 2000; Lamont 2000). Given the distinct structural and cultural conditions of the nations in which various African diasporafocused museums are located, future research should compare how local patrons define the value of museums in their respective countries. ${ }^{7}$ For example, we need to know more about how patrons in the United States and South Africa understand the worth of history museums in their home countries.

Another important area for future research related to global boundaries is how residence is associated with museum values among patrons supporting the same museums. In recent years there have been growing claims that a transnational business class has developed (Kentor and Jang 2004). ${ }^{8}$ Distinct from a national elite that dictates decisions on a national level, this transnational capitalist class is believed to dictate decisions across the globe. Although more research needs to be done on cross-national patronage at museums that focus on the history and culture of racial and ethnic minorities, there is evidence that it exists. For example, individuals based in the 


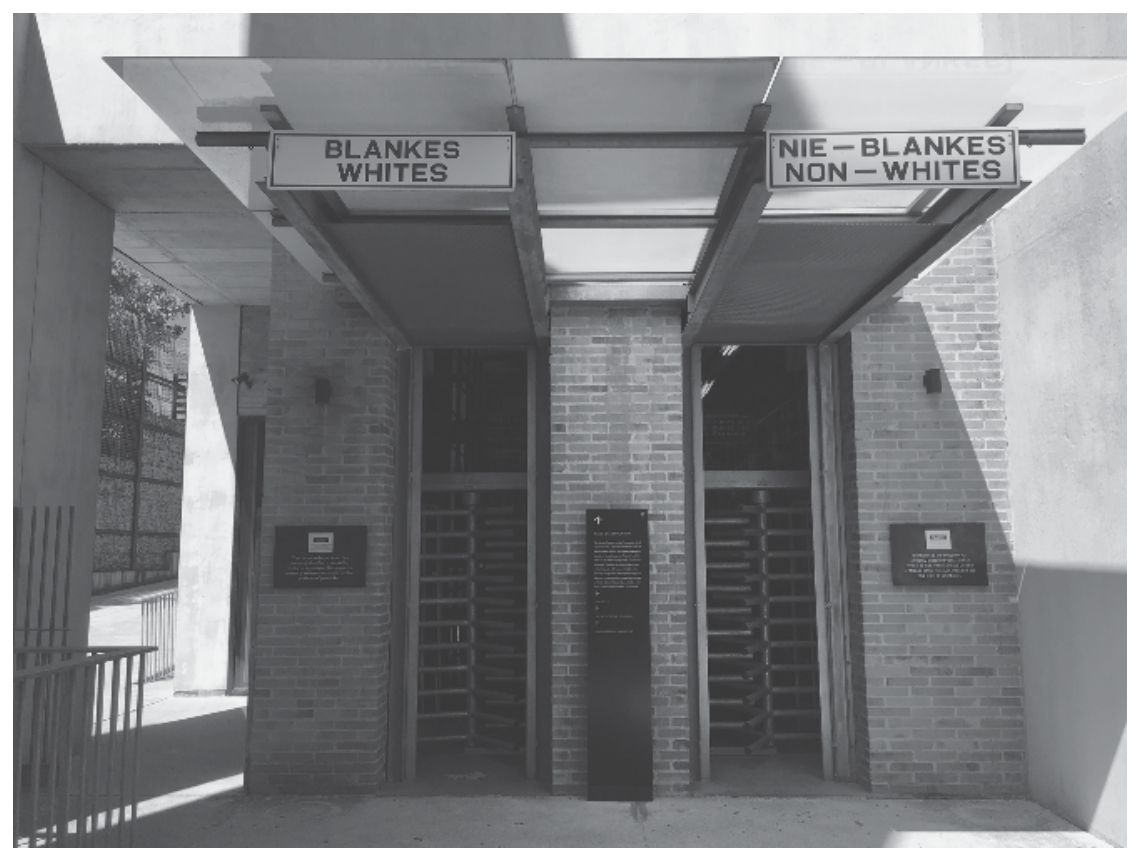

Figure 6.4 Entrance to the Apartheid Museum in Johannesburg, South Africa.

United States, Europe, and other parts of Africa are patrons of the new Zeitz MoCAA, and billionaire families based in Nigeria and London have given to the recent campaign by the Africa Center (formerly the Museum for African Art) (The Africa Center 2017). ${ }^{9}$ We need to know more about how the museum values of patrons who are local residents of a nation differ from those of patrons whose primary residence is outside of the country or those who have multiple residences. Also, given the finding in this study that, relative to native-born blacks, immigrant blacks place more emphasis on African American museums having an international focus, it is particularly important to undertake comparative research on how native-born and immigrant blacks in African and Caribbean countries, as well as blacks who reside within and outside of those nations, define the value of museums there. Comparing how African Americans and black Africans think about the place of African American art and artifacts in the collections of African museums could offer important insight on this issue. ${ }^{10}$

Other important questions raised by this study concern corporate giving as well as giving by connoisseurs and younger patrons. Chapter 3 offers insight into how individuals who work in the business sector understand the value of black museums in relation to their personal work lives. Future research needs to examine the motivations underlying black museum 
patronage by businesses as a whole. For instance, we need to know more about how supporting these and other ethnic museums shapes the public images of corporations. Insights from Chapter 4 concerning the emphasis that connoisseurs place on black museums for legitimizing black history and culture and building its economic value suggest that similar issues should be explored in more depth within the context of other ethnic museums. For example, we need to know more about how collectors of indigenous art and artifacts see the role of tribal museums in reinforcing the symbolic and economic value of these objects. This line of research will build on the work of scholars such as Arlene Dávila, $(2008,2012)$ who investigate the intersections between Latinx museums and value. Finally, Chapter 5 raises the issue of what younger patrons think about the place of contemporary political issues in other types of ethnic museums. For example, given the involvement of racial and ethnic minority youth in political movements, such as protesting the Dakota Access Pipeline (DAPL) and supporting Deferred Action for Childhood Arrivals (DACA) legislation (Blakemore 2018; Robles and Gomberg-Muñoz 2016), it is important to gain insight into the values of younger patrons at ethnic museums, such as tribal and Latinx museums.

Overall, the analysis shows the importance of examining intragroup differences in upper-middle- and upper-class museum patronage. In that vein, it will be important for future researchers to engage in comparative study of other social boundaries in more depth. While gender differences are touched on to a degree here, more research is needed on how patrons who identify across the gender spectrum, such as transgender men and women, value ethnic and other museums. Other background factors that merit indepth examination in research on museum patronage include, but are not limited to, sexual orientation, disability, and religion. To conclude, I briefly discuss the implications of this study for understanding important policy issues related to museum patronage.

\section{Practical implications}

In recent years there has been a growing mandate for museums of all types to diversify their ranks of patrons (Bernstein 2016; Grams and Farrell 2008; Loos 2016; Ostrower 2002, 39-62; Pogrebin 2017a, 2017b). One justification for pursuing a more diverse patron base is to help museums gain access to new sources of money. A narrow range of supporters limits a museum's access to capital. Increasing the diversity of patrons is also cast as important under the premise that art and culture are public goods that all people have a right to access (DiMaggio and Useem 1978a, 1978b; Zolberg 1981). In this view, having a narrow range of supporters allows the monopolization of a public good by a small subsection of a society. By adding perspective on the potential consequences of an increasingly heterogeneous base of patrons, the findings here offer insight into calls to diversify museum patronage. To be sure, increasing patron diversity may give museums access to more economic 
resources and bring them more in line with ideals of cultural democracy. But, given the finding that museum values vary according to the backgrounds of supporters, it is possible that by increasing the demographic diversity of patrons, museum leadership will also become more value-diverse. On the one hand, an infusion of new perspectives to museums may contribute to organizational growth and innovation. On the other hand, new views may also contribute to conflict. ${ }^{11}$ Given this potential, it is important that those who call for changes to the demographic base of supporters also consider the potential for a reduction of cohesion and exacerbation of conflict among patrons.

Another concern is that there will be what I term "patron flight," or movement of supporters away from one type of cultural institution to another, in this case from local black museums to the NMAAHC and majority museums. Although my findings suggest that increasing competition in the museum field might produce patron flight away from local African American museums, they also suggest that some patrons will continue to find local black museums appealing. First, I address whether or not the NMAAHC will compromise patronage at local black museums.

Although the NMAAHC opened in September 2016, the effort to found a national black museum started a hundred years earlier (Taft and Burnette 2003, 7-9). One obstacle in more recent decades was concern that a national black museum would diminish the resources of local black museums (Brown 1991). Some feared there would be patron flight from local black museums to the national black museum because of factors such as the latter's higher level of prestige, better capacity to care for and display objects, and more robust fundraising infrastructure.

My findings suggest that there is reason for such concern. Collectors who care a great deal about object care may prefer to give to the NMAAHC, which has more resources than most smaller local museums. Similarly, donors who are concerned with legitimization may choose the NMAAHC over some smaller local museums because of its greater power to validate black artifacts and art. However, there is also reason to believe that local African American museums will continue to attract and retain supporters precisely because they are local. As we saw in the chapter on racial value, some supporters consider black museums an important part of the institutional fabric of black communities. For them, to give to their local black museum is to fortify African American neighborhoods. Some patrons also see black museums as an important part of local black middle- and upperclass social life. Similarly, for connoisseurs who personally want regular exposure to black art and artifacts, local African American museums are convenient to visit.

The continuing significance of local black museums to some patrons is illustrated by the experience of Eric Whitaker, a new trustee at the DuSable Museum of African American History in Chicago. Whitaker was inspired to join the board after visiting the NMAAHC. When the museum's director 
first reached out to him to join the board, he had intended to decline the offer. But, after a visit to the NMAAHC, his decision changed. "I came back inspired and changed my mind," he recounts. "We need a museum in Chicago that will tell the African American narrative and our contributions to this country" (Johnson 2017).

Questions have also been raised about patron flight from African American museums to majority museums. This concern emerges from the growing commitment by majority museums to increase holdings and exhibitions related to African American history and culture and to grow their base of black supporters. ${ }^{12}$ Across the United States, majority museums, such as the Museum of Modern Art in New York and the Detroit Institute of Art, have specific initiatives to collect work by African American artists. ${ }^{13}$ With a desire to capture some of the new black wealth, and in response to internal critique as well as admonishment from the public, foundations, and government that their patron bases lack diversity, majority museums are also moving to increase their numbers of black supporters (Bernstein 2016; Grams and Farrell 2008; Loos 2016; Ostrower 2013, 1-32, 39-62; Pogrebin 2017b). For example, in the next five years the Museum of the City of New York aims to increase trustees of color by 25 percent (Pogrebin 2017b). One black museum staffer I interviewed noted this increasingly competitive environment. "By 2000, I realized that African Americans institutions were competing with white institutions for black money, because white institutions were now very interested in diversifying boards," she explained.

Amid these shifts there are concerns that the philanthropic base of African American museums will be eroded as black donors and other donors with an interest in black history and culture are lured to majority museums (Pogrebin 2017b). The evidence presented here suggests that patron flight is a legitimate concern because majority museums typically excel in some areas that some subgroups of black museum patrons especially value. For example, among connoisseurs who are concerned with cultural prestige and object care, large majority museums that are considered the best museums in their cities and that have the latest technology and facilities to preserve objects may appeal more than smaller African American museums. However, it is important to note that unique facets of African American museums and their contexts may continue to make black museums appealing to patrons in the face of majority museums launching diversity initiatives. Although majority museums are indeed becoming more black in terms of collections and exhibitions, it is still not their core focus, in contrast to African American museums. Similarly, although there are efforts at majority museums to increase black patrons, black museums typically have a relatively larger base of black supporters (Banks 2017b; Pogrebin 2004). To be sure, the fact that majority museums are behind in these areas can be a motivation for some diversity-minded donors to give to them-for example, as we saw in Chapter 4, some patrons described how they also give to majority museums precisely because their collections and exhibitions lack diversity. However, 
for supporters who place high value on black collections and exhibitions, a black museum that is dedicated to them may continue to be attractive. Similarly, for black patrons who value not being the only black patron, or not being one of just a few, giving to black museums where there is still a higher concentration of black supporters may continue to appeal to them until majority museums significantly change in this respect.

Through an examination of African American museums, this book offers a foundation for understanding fundamental issues related to diversity and cultural philanthropy. With shifting racial and ethnic demographics and growing pressure to diversify the ranks of cultural supporters, it is now more important than ever to gain insight into how different types of patrons value cultural organizations. This is critical not only for gaining theoretical and conceptual insights that illuminate the relationship between social and cultural boundaries, but also for building a more equitable cultural landscape.

\section{Notes}

1 As John H. Falk $(2013,110)$ notes in his research on museum engagement, "thousands of visitor studies have been conducted" by museums to gain insight into the demographic characteristics of visitors. While much of this research remains unpublished, race and ethnicity are among the background factors that are analyzed.

2 For example, although in 2009 close to half of Asian Americans had at least a Bachelor's degree, around one-third of whites had a similar level of education. The same year, the median family income for Asian Americans was \$78,529 and $\$ 65,319$ for whites ("Selected Characteristics of Racial Groups" 2012, 41). The proportion of Asian and Pacific Islanders making \$100,000 and over in 2009 also surpassed whites at 37.7 percent versus 27 percent, respectively (Money Income 2012, 455).

3 In 2009 only 12.6 percent of Latinxs had a BA or higher degree, compared to 31.1 percent of non-Hispanic whites. However, among Latinxs that year, 27.9 percent of Cuban Americans had a college degree, while only 9.5 percent of Mexican Americans had one. Despite lower socioeconomic outcomes among some Latinx ethnic groups, such as Mexican Americans, there is some evidence that these groups will experience upward mobility over time and join the middle class (Agius Vallejo 2012; Jiménez 2009).

4 It is estimated that there are more than 2,000 ethnocultural arts organizations in the United States. This does not include cultural organizations that do not focus specifically on the arts. For example, some black history museums are not included in this count (Matlon et al. 2014, 4, 24).

5 In Uganda there are plans to build a museum focused on the regime of former president Idi Amin that will also focus on the nation's pre- and postcolonial history ("Uganda to Build" 2018). There are also plans to build the Benin Royal Museum, which will house, among other objects, bronze sculptures taken from Benin City by British troops in 1897 (Hickley 2018).

6 There are approximately 255 ethnocultural arts organizations in Canada (Matlon et al. 2014, 4). 
7 While not focused on patronage per se, Robin Autry's (2017a) Desegregating the Past: The Public Life of Memory in the United States and South Africa offers a comparative analysis of how museums in the United States and South Africa narrate violent racial pasts. Also, in her research on museum-going at natural history museums in London, Nairobi, and New York, Monique Scott finds that national residence is associated with how visitors interpret exhibitions (Scott 2008, 145-47). Specifically, Kenyan residents are more attentive to linkages between museums and colonialism.

8 Other scholars assert that claims of a transnational elite are overstated (Korsnes et al. 2018).

9 While no longer exclusively focused on art, the center still promotes art from Africa as part of its mission (The Africa Center 2017).

10 Research of this nature could be undertaken at African museums that center on African culture or history but also include art and artifacts from other parts of the African diaspora. For example, the Zeitz MoCAA collection includes work by African American artists such as Glenn Ligon, Kehinde Wiley, and Hank Willis Thomas.

11 Scholarship focused on the effects of leadership diversity on organizational outcomes in the corporate sector also suggests that it could either enhance or compromise performance (Cook and Glass 2015).

12 See, for example, the Friends of African and African American Art programs at museums across the United States, such as at the Cleveland Museum of Art, the Detroit Institute of Arts, and the Saint Louis Art Museum. Internationally, museums such as the Tate in London are devising patron programs directed at the African diaspora, such as the Africa Acquisitions Committee focused on collecting contemporary art from the continent.

13 In 2014, Darby English was hired as a consulting curator at MoMA to enrich holdings of art by African Americans, and in 2016 the Detroit Institute of Arts launched a multimillion-dollar initiative to acquire work by African American artists (Solomon 2014; Stryker 2016).

\section{References}

Abrams, George H. J. 2004. Tribal Museums in America. Nashville, TN: American Association for State and Local History.

The Africa Center. 2017. The Campaign to Build the Africa Center. New York, NY: The Africa Center.

Agius Vallejo, Jody. 2012. Barrios to Burbs: The Making of the Mexican American Middle Class. Stanford, CA: Stanford University Press.

Anderson, Monica, and Gustavo López. 2018. "Key Facts about Black Immigrants in the U.S.” Pew Research Center, January 24, 2018. Accessed February 10, 2018. www.pewresearch.org/fact-tank/2018/01/24/key-facts-about-black-immigrantsin-the-u-s/.

Ardali, Azade. 1989. Black and Hispanic Art Museums. New York, NY: Ford Foundation.

Autry, Robyn K. 2017. Desegregating the Past: The Public Life of Memory in the United States and South Africa. New York, NY: Columbia University Press.

Banks, Patricia A. 2017. "Ethnicity, Class, and Trusteeship at African American and Mainstream Museums.” Cultural Sociology 11(1): 97-112. 
Bernstein, Jacob. 2016. “The Disrupters: Making New York’s Cultural Boards More Diverse." New York Times, July 30, 2016. Accessed August 10, 2016. www. nytimes.com/2016/07/31/style/diversity-cultural-boards-trustees-new-york.html.

Blakemore, Erin. 2018. "Youth in Revolt: Five Powerful Movements Fueled by Young Activists.” National Geographic, March 23, 2018. Accessed June 19, 2018. https://news.nationalgeographic.com/2018/03/youth-activism-young-protestershistoric-movements/.

Bourdieu, Pierre, Alain Darbel, and Dominique Schnapper. 1991. The Love of Art: European Art Museums and Their Public. Cambridge, UK: Polity Press.

Brown, Claudine. 1991. Final Report of the African American Institutional Study. Smithsonian Institution Archives, Accession 07-172. Washington, DC: National Museum of African American History and Culture, Planning Records.

Cook, Alison, and Christy Glass. 2015. "Diversity Begets Diversity? The Effects of Board Composition on the Appointment and Success of Women CEOs." Social Science Research 53: 137-147.

Cooper, Karen Coody and Nicolasa I. Sandoval, eds. 2006. Living Homes for Cultural Expression: North American Native Perspectives on Creating Community Museums. Washington, DC and New York: National Museum of the American Indian, Smithsonian Institution.

Council of American Jewish Museums (CAJM). n.d. "About." Council of American Jewish Museums. Accessed January 12, 2018. www.cajm.net/about-us/.

Dávila, Arlene. 2008. "From Barrio to Mainstream: On the Politics of Latino/a Art Museums." In Latino Spin: Public Image and the Whitewashing of Race, edited by Arlene Dávila, 119-137. New York, NY: NYU Press.

- 2012. "The Trials of Building a National Museum of the American Latino." In Culture Works: Space, Value, and Mobility Across the Neoliberal Americas, 94-111. New York, NY: NYU Press.

DiMaggio, Paul. 1982a. "Cultural Entrepreneurship in Nineteenth-Century Boston, Part 2: The Classification and Framing of American Art." Media, Culture, and Society 4: 303-322.

- 1982b. "Cultural Entrepreneurship in Nineteenth-Century Boston: The Creation of an Organizational Base for High Culture." Media, Culture, and Society 4: 33-50.

DiMaggio, Paul, and Francie Ostrower. 1987. Race, Ethnicity, and Participation in the Arts: Patterns of Participation by Black, Hispanic, and White Americans in Selected Activities from the 1982 and 1985 Surveys of Public Participation in the Arts. Washington, DC: National Endowment for the Arts.

- 1990. "Participation in the Arts by Black and White Americans." Social Forces 68(3): 753-778.

DiMaggio, Paul, and Michael Useem. 1978a. "Cultural Democracy in a Period of Cultural Expansion: The Social Composition of Arts Audiences in the United States." Social Problems 26(2): 179-197.

- 1978b. "Cultural Property and Public Policy: Emerging Tensions in Government Support for the Arts.” Social Research 45(2): 356-389.

Falk, John H. 2013. "Understanding Museum Visitors' Motivations and Learning." In Museums: Social Learning Spaces and Knowledge Producing Processes, edited by Ida Brændholt Lundgaard and Jacob Thorek Jensen, 106-133. Copenhagen, Denmark: Kulturstyrelsen.

Grams, Diane, and Betty Farrell. 2008. Entering Cultural Communities: Diversity and Change in the Nonprofit Arts. New Brunswick, NJ: Rutgers University Press. 
Hickley, Catherine. 2018. "Benin Dialogue Group Announces Three-Year Schedule for New Royal Museum to Display Looted Objects Now in European Collections." The Art Newspaper, October 22, 2018. Accessed October 22, 2018. www. theartnewspaper.com/news/nigeria-plans-museum-for-art-looted-from-benin

H.R. 868. 2017. National Museum of Asian Pacific American History and Culture Act, 115th Congress (2017).

H.R. 2911. 2017. National Museum of the American Latino Act, 115th Congress (2017).

Jiménez, Tomás. 2009. Replenished Ethnicity: Mexican Americans, Immigration, and Identity. Berkeley, CA: University of California Press.

Johnson, Steve. 2017. "Chance the Rapper Joins DuSable Museum Board.” Chicago Tribune, January 6, 2017. Accessed June 10, 2017. www.chicagotribune.com/ entertainment/ct-chance-the-rapper-dusable-museum-board-20170106-column. html.

Kentor, Jeffrey, and Yong Suk Jang. 2004. "Yes, There Is a (Growing) Transnational Business Community: A Study of Global Interlocking Directorates 1983-98.” International Sociology 19(3): 355-368.

Korsnes, Olav, Johan Heilbron, Johs. Hjellbrekke, Felix Bühlmann, and Mike Savage, eds. 2018. New Directions in Elite Studies. New York, NY: Routledge.

Lamont, Michèle. 2000. The Dignity of Working Men: Morality and the Boundaries of Race, Class, and Immigration. Cambridge, MA: Harvard University Press.

Lamont, Michèle, and Laurent Thévenot. 2000. Rethinking Comparative Cultural Sociology: Repertoires of Evaluation in France and the United States. Cambridge, UK: Cambridge University Press.

Loos, Ted. 2016. "Speed Museum Turns to a Spreadsheet to Increase Diversity." New York Times, March 15, 2016. Accessed April 10, 2017. http://nyti.ms/ 1U4OtOf.

Loukaitou-Sideris, Anastasia, and Carl Grodach. 2004. "Displaying and Celebrating the 'Other': A Study of the Mission, Scope, and Roles of Ethnic Museums in Los Angeles.” Public Historian 26(4): 49-71.

Matlon, Mina Para, Ingrid Van Haastrecht, and Kaitlyn Wittig Mengüç. 2014. Figuring the Plural: Needs and Supports of Canadian and US Ethnocultural Arts Organizations. Chicago, IL: School of the Art Institute of Chicago/Art Institute of Chicago.

"Money Income of Families-Percent Distribution by Income Level in Constant (2009) Dollars: 1980 to 2009," no. 696. 2012. In Statistical Abstract of the United States: 2012, 455. Washington, DC: Government Printing Office.

National Endowment for the Arts. 1992. Cultural Centers of Color. Washington, DC: National Endowment for the Arts.

National Museum of the American Latino Commission. 2011. National Museum of the American Latino Commission Final Report. Washington, DC: National Museum of the American Latino Commission.

Ostrower, Francie. 1999. "The Arts as Cultural Capital among Elites: Bourdieu's Theory Revisited.” Poetics 26: 43-53.

- 2002. Trustees of Culture: Power, Wealth, and Status on Elite Arts Boards. Chicago, IL: University of Chicago Press.

—. 2013. "Diversity on Cultural Boards: Implications for Organizational Value and Impact.” Working Paper, National Endowment for the Arts, Washington, DC. 
Pogrebin, Robin. 2004. "Many Arts Groups in City Lag in Naming Blacks as Trustees." New York Times, May 2, 2004. Accessed August 25, 2016. www. nytimes.com/2004/05/25/nyregion/many-arts-groups-in-city-lag-in-namingblacks-as-trustees.html.

—. 2017a. "De Blasio, with 'Cultural Plan,' Proposes Linking Money to Diversity.” New York Times, July 19, 2017. Accessed August 10, 2017. www. nytimes.com/2017/07/19/arts/design/new-york-cultural-plan-museums.html.

— 2017b. "It's a Diverse City, but Most Big Museum Boards Are Strikingly White.” New York Times, August 22, 2017. Accessed August 25, 2017. https:// nyti.ms/2vlbVw8.

Quinn, Eithne. 2010. Nuthin' but a “G” Thang: The Culture and Commerce of Gangsta Rap. New York, NY: Columbia University Press.

Robles, Jorge Mena, and Ruth Gomberg-Muñoz. 2016. "Activism after DACA: Lessons from Chicago's Immigrant Youth Justice League.” North America Dialogue 19(1): 46-54.

Scott, Monique. 2008. Rethinking Evolution in the Museum: Envisioning African Origins. London, UK: Routledge.

Selected Characteristics of Racial Groups. 2012. "Selected Characteristics of Racial Groups and Hispanic Or Latino Population: 2009, no. 36.” In Statistical Abstract of the United States: 2012, 40-41. Washington, DC: Government Printing Office.

Solomon, Deborah. 2014. "Student of History Is Making Some: Darby English Joins MoMA as Consulting Curator.” New York Times, April 2, 2014. Accessed June 13, 2017. www.nytimes.com/2014/04/06/arts/design/darby-english-joins-momaas-consulting-curator.html.

Stryker, Mark. 2016. "DIA Launches Multimillion-Dollar Effort to Acquire AfricanAmerican Art.” Detroit Free Press, July 20, 2016. Accessed August 10, 2017. www.freep.com/story/entertainment/arts/2016/07/20/dia-african-american-artdavid-hammons/87291024/.

S. 1364. 2017. National Museum of the American Latino Act, 115th Congress (2017).

Taft, J. Richard, and Alice Green Burnette. 2003. Final Report: Planning and Organization for a Private Sector Fundraising Campaign in Behalf of the National Museum of African American History and Culture. Smithsonian Institution Archives, Accession 07-172. Washington, DC: National Museum of African American History and Culture, Planning Records.

Zolberg, Vera L. 1981. "Conflicting Visions in Art Museums." Theory and Society 10(1): 103-125.

Zweigenhaft, L., and Domhoff, GW. 2011. The New CEOs: Women, African American, Latino and Asian American Leaders of Fortune 500 Companies. Lanham, MD: Rowman and Littlefield.

- 2018. Diversity in the Power Elite: Ironies and Unfulfilled Promises. Lanham, MD: Rowman and Littlefield. 


\section{Appendix 1 \\ African American museums: Basic characteristics $^{1}$}

\section{What is an African American museum?}

The various definitions of "museum" are notoriously fuzzy. For example, some definitions are narrow and exclude broad swaths of institutions such as those that are noncollecting or without a physical location, while others are more inclusive, including organizations as diverse as zoos, planetariums, and historic sites. The flexibility of the concept is perhaps best captured by a statement in the 2008 National Standards and Best Practices for U.S. Museums guide: "We may have to live with the fact that 'museum' as a concept is the intersection of many complex categories, resulting in an organization that people can identify intuitively but that cannot be neatly packaged in a definition" (American Association of Museums 2008, 3).

The fact that "African American museums" are also distinguished in reference to race and ethnicity further complicates their definition. The racial dimension of African American museums not only has to consider questions of who is African American, but also what about the museums is African American, and how much African Americanness is sufficient to warrant inclusion. For example, although "African American" could presumably refer strictly to history and culture related to people of African descent within the context of the United States, the 2003 National Survey of African American Museums (Austin 2003) includes organizations that are African focused, such as the National Museum of African Art and the former Museum for African Art.

Questions concerning what about a museum should be African American in order to garner this designation are brought to the fore in the 1988 Association of African American Museums (AAAM) report Profile of Black Museums. Noting that it was challenging "to define those characteristics that made a museum distinctively a 'Black' museum," the authors settled on not only a mission-focused definition, but also one that referenced black leadership. "Your museum must have significant representation in both its operations and governance by Black persons (i.e., person(s) of continental African descent)," the report explains (African American Museums Association 1988, 15). However, a decade later, the 2008 AAAM/IMLS 
(Institute of Museum and Library Services) cosponsored survey on African American cultural institutions refers to mission only in defining what about a museum makes it black. Yet, even with mission there can be questions about the degree of focus that is required to merit inclusion.

The 1988 AAAM survey and the IMLS grant criteria designate African American museums (or black museums in the case of the AAAM report) as those having a "primary" focus on African Americans. The 2008 AAAM/ IMLS survey report further clarifies the issue of quantity by establishing a specific percentage necessary for inclusion. The report notes that "an organization's mission needed to be at least $50 \%$ focused on African American history or culture to qualify" (Hayward and Werner 2008, 1).

This discussion highlights the complexity of labeling a subset of cultural organizations as "African American." I take a broad view of this designation. A broad scope allows researchers and others interested in this type of institution to explore the full range of organizations that can fall within this category. Ultimately, the cultural institutions included in this study are linked by having missions with a significant focus on the history and culture of people from the African diaspora. I should also note that I use "African American museum" and "black museum" interchangeably. This usage is common in the broader field. ${ }^{2}$

\section{How does the National Museum of African American History and Culture fit into the broader field of African American museums?}

Given that the NMAAHC is now arguably the world's best-known African American museum, it is instructive to consider how it compares to others in the field. ${ }^{3}$ While the NMAAHC is now the most widely recognized African American museum, it is part of a broader field of more than 300 cultural organizations in the United States focused on black history and culture. ${ }^{4}$ Here, I contextualize the NMAAHC within the broader field of African American museums and related institutions.

Perhaps the most significant departure of the NMAAHC from other African American museums is size. As measured by budget, most African American museums are significantly smaller in budget. The 2017 budget for the NMAAHC is $\$ 41.3$ million (Newsdesk: Press Room of the Smithsonian Institution 2017). The NMAAHC stands out because it is the only museum in the field of African American museums that has a budget of this vast size. ${ }^{5}$

Although the NMAAHC departs from other African American museums with its especially large budget, its southern roots are common. States such as Georgia and Florida have more than two dozen museums apiece. In sharp contrast, evidence points to there being fewer black museums in the West, particularly in states outside of California. These regional patterns appear to map onto broader geographic patterns of African American residence and experience. For example, cultural institutions focused on slavery, such 
as the Old Slave Mart Museum and the Slave Haven Underground Railroad Museum, appear to be more common in the South.

The NMAAHC's concern with history, as well as its designation as a "history and culture" institution, are also typical. Most African American museums have history as a primary or significant focus. Museums that focus on fine art, such as the Studio Museum in Harlem, are less common. On the one hand, the common focus on black history is in keeping with the long-standing concern with black history in African American public life. On the other hand, the popularity of African American history museums is also consistent with a broader pattern in the museum field where historical organizations dominate.

\section{Notes}

1 This appendix is adapted from blog posts on www.patriciaannbanks.com.

2 For example, in the History section of the Association of African American Museums website, both terms are used. Similarly, the name of the organization uses "African American" in the title, but its website uses "black museum" (www. blackmuseums.org/).

3 In preparing the African American Museums Database (AAMD), I researched a range of factors about each museum, such as their location, founding date, and budget. To determine this information, I relied on sources such as IRS Form 990 filings and museum websites. My discussion of the field of black museums is based on data from the AAMD as well as findings from AAAM surveys.

4 This estimate of the number of black museums in the United States is based on research that I undertook in 2016. At that time, I used multiple sources to identify cultural institutions that fit my working definition of black museums-cultural institutions with a significant focus on the history and culture of people from the African diaspora. To begin the list, I added all museums included in the National Survey of African American Museums (Austin 2003). I also searched for black museums in various news databases and search engines using search strings such as "museum [and] black" and "museum [and] African American." This was a time-consuming process that required reviewing many websites and articles that were not in fact related to black museums. For example, my search brought up articles related to African Americans at majority museums. However, I did add dozens of museums that were not included in the initial list. I also added museums that I came across through my broader ethnographic and archival research on black museums. Once I had this initial list, I checked to see whether each museum was currently open to the public by seeing if it had what appeared to be an active website or by calling. Several museums were eliminated because they seemed to no longer exist or have ever been fully established. Through this process, I came up with a list of 345 museums. I made the list available to the public as part of a searchable online database, the African American Museums Database (AAMD), in September 2016. As I was preparing this list, AAAM was undertaking a needs assessment that involved identifying the population of African American museums. At their annual meeting in August 2017, they presented findings from their study. Their count of black museums is 215 (Association of African American Museums 
2017, 4). Given the variable definitions of terms such as "African American" and "museum," it is not surprising that there are different estimates of the number of black museums. Indeed, the counts of other ethnic museums, such as tribal museums, also vary significantly (Abrams 2004, 3). It is also likely that varying methods for identifying black museums may also contribute to different estimates. The process of using search strings related to black museums to find them in search engines and databases may have contributed to identifying a larger number.

5 Partly to mitigate the effects of one dominant institution in the field, the legislation for establishing the NMAAHC included a grant program to support other African American museums. The IMLS Museum Grants for African American History and Culture established in 2006 are part of the broader support at the federal level for these organizations.

\section{References}

Abrams, George H. J. 2004. Tribal Museums in America. Nashville, TN: American Association for State and Local History.

African American Museums Association. 1988. Profile of Black Museums. American Association for State and Local History Book Series. Washington, DC: African American Museums Association.

American Association of Museums. 2008. National Standards and Best Practices for U.S. Museums, edited by Elizabeth E. Merritt. Washington, DC: American Association of Museums.

Association of African American Museums. 2017. 2017 National Needs Assessment for the Association of African American Museums. Washington, DC: Association of African American Museums.

Austin, Joy Ford. 2003. National Survey of African American Museums: Prepared for the National Museum of African American History and Culture Plan for Action Presidential Commission. Washington, DC: National Museum of African American History and Culture Plan for Action Presidential Commission.

Hayward, Jeff, and Brian Werner. 2008. Assessment of the Field: African American Cultural Organizations. Northampton, MA: Association of African American Museums.

Newsdesk: Press Room of the Smithsonian Institution. 2017. Fact Sheets-National Museum of African American History and Culture. Washington, DC: Smithsonian Institution. 


\section{Appendix 2 Methods}

I became curious about why individuals support African American museums during the course of researching my book Represent: Art and Identity Among the Black Upper-Middle Class (Banks 2010). Several of the collectors I interviewed for that study were also supporters of African American museums. My interest in the topic was further piqued by the multimilliondollar fundraising campaign for the NMAAHC that was underway at the time.

To understand how supporters define the value of African American museums, I draw on in-depth interviews, ethnographic observations, and archival research. Data collection took place over the course of around a decade, with much of the work concentrated in 2008, 2012, and 2016. Over this period, I interviewed a diverse group of eighty-four supporters at seventeen museums in eleven cities. ${ }^{1}$ As noted in Appendix 1, there is tremendous variation in the field of black museums along dimensions such as focus, size, and location. Supporters were typically sampled from large and mid-sized black museums with a range of focuses. ${ }^{2}$ For example, some participants are patrons of black museums with a historical focus, while others support museums that center on fine art. The study includes supporters of museums from each of the four major regions in the United States. I traveled to various cities to conduct the interviews, and I continued until I reached saturation. ${ }^{3}$ Each interview took place at a time and location of the participant's choosing. This was typically during the morning or afternoon at a place of work, but I also met some participants in the evening, and talked with them in other places such as homes, restaurants, and cafes. Interviews were taped and typically lasted around 90 minutes.

I asked participants a range of questions designed to elicit information about their involvement with, and views about, black museums. I typically began by asking how and why they first became involved with supporting black museums, and I would often end by asking where they would like to see the black museum(s) that they support in ten years. Although I used an interview guide, I typically varied the order of questions to encourage a conversational tone. The interviews focused on participants' experiences and perspectives related to supporting black museums. However, I also probed 
their broader cultural patronage, philanthropic involvement, and personal backgrounds. Information about their backgrounds, such as the types of people in their networks and communities, was generated in the course of answering these broader questions, in addition to the more central responses about black museum patronage. At the end of interviews, participants filled out an extensive demographic questionnaire, including questions related to their racial and ethnic identity, socioeconomic status, age, and political views. After each interview, I also spent time writing field notes.

To analyze the in-depth interviews, I examined a subset of transcripts and then developed a coding key centering on museum values. I subsequently applied the coding scheme to the whole set of transcripts using NVivo, which is a qualitative data analysis program. Through this process, I categorized participants' museum values inductively and compared across subgroups.

Along with the formal interviews with supporters, I also conducted a small number of formal interviews with museum staff. In addition to these formal interviews, I also had dozens of informal discussions with supporters, staff, and other constituents in the world of African American museum philanthropy over the course of my research. ${ }^{4} \mathrm{My}$ understanding of philanthropy at these museums also draws on participant observation at museum events such as fundraising galas. For a time, I was also a member of a friend's groups for young professionals at one museum. ${ }^{5}$ To understand the broader context of museum patronage in each city, I visited majority museums and, when possible, other ethnic museums during my trips. I also attended two conferences for the Association of African American Museums. In addition to reading dozens of newspaper and magazine articles on African American museums, I visited archives for museums such as the National Museum of African American History and Culture. I also collected online data from museums, such as information from enewsletters. Finally, I draw on a database that I compiled that includes more than 2,000 donations of $\$ 25,000$ or more to African American museums and a database that I created that includes more than 500 trustees at large black museums. ${ }^{6} \mathrm{I}$ also collected data on million-dollar gifts to all Smithsonian museums from 2005 to 2016 to gain insight into the broader context of philanthropy at the NMAAHC.

Supporters in this study mostly include trustees, committee members, and members of friends' groups. Because more than three-quarters of the interviewees are trustees, I gained a rich understanding of views about governance. I identified participants mainly through publicly available lists of supporters, such as trustee lists in annual reports and on museum websites. I selected a smaller number of participants through snowball sampling or existing networks. I typically called patrons' offices to recruit for the study, though in some cases I emailed or called their homes. Given their socioeconomic status, most participants are best described as upper-middle or upper class. They typically have graduate degrees, earn six-figure salaries or more, and work in professional and managerial jobs. Generationally, around one-third are members of Generation X or Millennials, while the 
rest are baby boomers and members of the Silent and G.I. Generations. Racially, the sample is around 70 percent black and 27 percent white. The remaining describe themselves as Afro-Latinxs. Around 13 percent of participants are first- or second-generation Americans. About 65 percent of participants work in the private sector. Of private-sector workers, most are executives or managers, entrepreneurs, or lawyers. The remaining are employed in jobs such as public-sector attorneys and judges, professors and school administrators, and nonprofit managers. ${ }^{7}$ There is a slightly smaller proportion of appreciators than connoisseurs. The latter have a higher level of involvement in cultural activities outside of black museum patronage.

My access to supporters and their interactions with me during interviews were likely shaped by my own background. My racial status as an African American and as a graduate of Spelman College, a Historically Black College and University, and my background as a professor at Mount Holyoke College, a Seven Sisters College, with a PhD and AM from Harvard University, an Ivy League school, may have contributed to some patrons' willingness to participate in the study and fostered a degree of familiarity during the interviews. Sharing the same race with some participants, and not sharing the same race with others, has strengths and limitations. Qualitative researchers note that when interviewers and interviewees share the same race, the latter can be more immediately comfortable and forthcoming (Lacy 2007; Lamont et al. 2016). However, as noted in other methodological reflections on "studying up"-or, engaging in research with members of the upper-middle and upper class-my educational overlap with white patrons might have mitigated some of the unease that can accompany interracial interactions that involve crossing racial and class boundaries (Lacy 2007). Moreover, given that there is a high concentration of blacks in the world of philanthropy at black museums, white participants in this study have regular interactions with blacks through their museum patronage. While sharing the same race with interviewees can foster a sense of intimacy, it can also pose challenges. Interviewees sometimes gloss over details that they assume interviewers already know about by virtue of being a member of the same racial in-group. I was conscious of this during interviews and made an effort to probe further when it appeared that this was taking place.

\section{Notes}

1 Although individuals were recruited based on their support of one black museum, in the course of interviews, I discovered that some are also supporters of other black museums.

2 See Appendix 1 for a discussion about black museums and size. It is likely that findings are shaped by the fact that supporters in this study generally give to large and mid-sized black museums.

3 In a few cases, I was not able to arrange interviews with patrons while I was visiting their cities, so I conducted phone interviews with them. 
4 At some points, I also draw on ethnographic and archival data from my earlier study on art collecting.

5 In the course of collecting data for my first book, I was also a member of a young professionals group at a black museum in another city.

6 The donations database was compiled from publicly available information on annual gifts and campaign gifts from 16 mainly large black museums. The trustee database includes board members from the largest black museums, along with trustees from museums that patrons in this study support.

7 A few participants were retired. Given that they often discussed patronage in relationship to work-for example, former managers discussing the job skills and knowledge that they bring to trusteeship-retired participants' work classification is designated as the last job that they held for which they were paid a salary.

\section{References}

Banks, Patricia A. 2010. Represent: Art and Identity Among the Black Upper-Middle Class. New York, NY: Routledge.

Lacy, Karyn R. 2007. Blue-Chip Black: Race, Class, and Status in the New Black Middle Class. Berkeley, CA: University of California Press.

Lamont, Michèle, Graziella Moraes Silva, Jessica S. Welburn, Joshua A. Guetzkow, Nissim Mizrachi, Hanna Herzog, and Elisa Reis. 2016. Getting Respect: Responding to Stigma and Discrimination in the United States, Brazil, and Israel. Princeton, NJ: Princeton University Press. 


\section{Index}

acquisitions 118-120

activism 159-169

aesthetic mobility 115-120

agents of consecration 115-118

architects 134

art market 117, 123-124, 141

audiences 136

Bill Gates 2, 42

Black Lives Matters 159-169

black middle and upper-class 34-44

black museum movement 3-9

black-owned businesses 88

children 61-63

civil rights generation 147-148

Civil Rights Movement 166-169

class interests 177

class reproduction 106

clients 99-102

collecting 116-117, 122-124

collections care 120-121, 129-130, 136

contemporary culture 153-158

contribution setting 91

corporate boards 89

corporate social responsibility 83-85

cultural capital 106, 139, 170, 176-178

cultural capitalists $14,111,118$

cultural legitimation 115-120

culture of poverty 170

curators 123-126

democratization 177

diversity and museums 14-17

earned income 94-95

enlightened self-interest 83-85

ethnic museums 179-184 ethnicity 70-73, 178

exterior views 134

family history 58-61

friends groups 121-123

fundraising 12, 90-92

generational habitus 147

generations 146-148

gentrification $51-58$

gift giving 100-101

global elite 182-183

globalization 180-183

high culture 118

hip hop 153-155

Historically Black Colleges and

Universities (HBCUs) 3, 36, 88, 120, 130, 198

immigrants 70-73, 178

interior views 134

mainstream museums 126-136, 185-187

mentorship 98-99, 102-103

Michael Jordan 1, 61

museum as forum 163

museum fields 126-136, 139-140, 185-187

museum partnerships 131-132

museum values $16-17$

narratives $58-70$

National Museum of African American

History and Culture (NMAAHC) 1, 33, 43-44, 155, 174, 193-194

neighborhoods $48-58$

networking 96-102 
Oprah Winfrey 1-2, 4, 42, 61

parenting 61-63

patron flight 185-187

post-civil rights generation 147-148

prejudice 69

public forums 165-167

racial and ethnic minority middle- and upper class 179

racial uplift 40-44

reception 17

redevelopment 51

Shonda Rhimes 1, 3

skills and knowledge 92-96

social bundaries 14-16 social capital $89,96-102$

social media $148-153$

social organizations 36

social status 38-39

staff 125-126, 133-134

stigmatization 49-50, 52-54

The Talented Tenth 40

technological habitus 148

technology 148-153

trustee 167-169

upper-middle and upper class 176-177

wealth inequality $41-43$

young professionals $58,146,157$ 


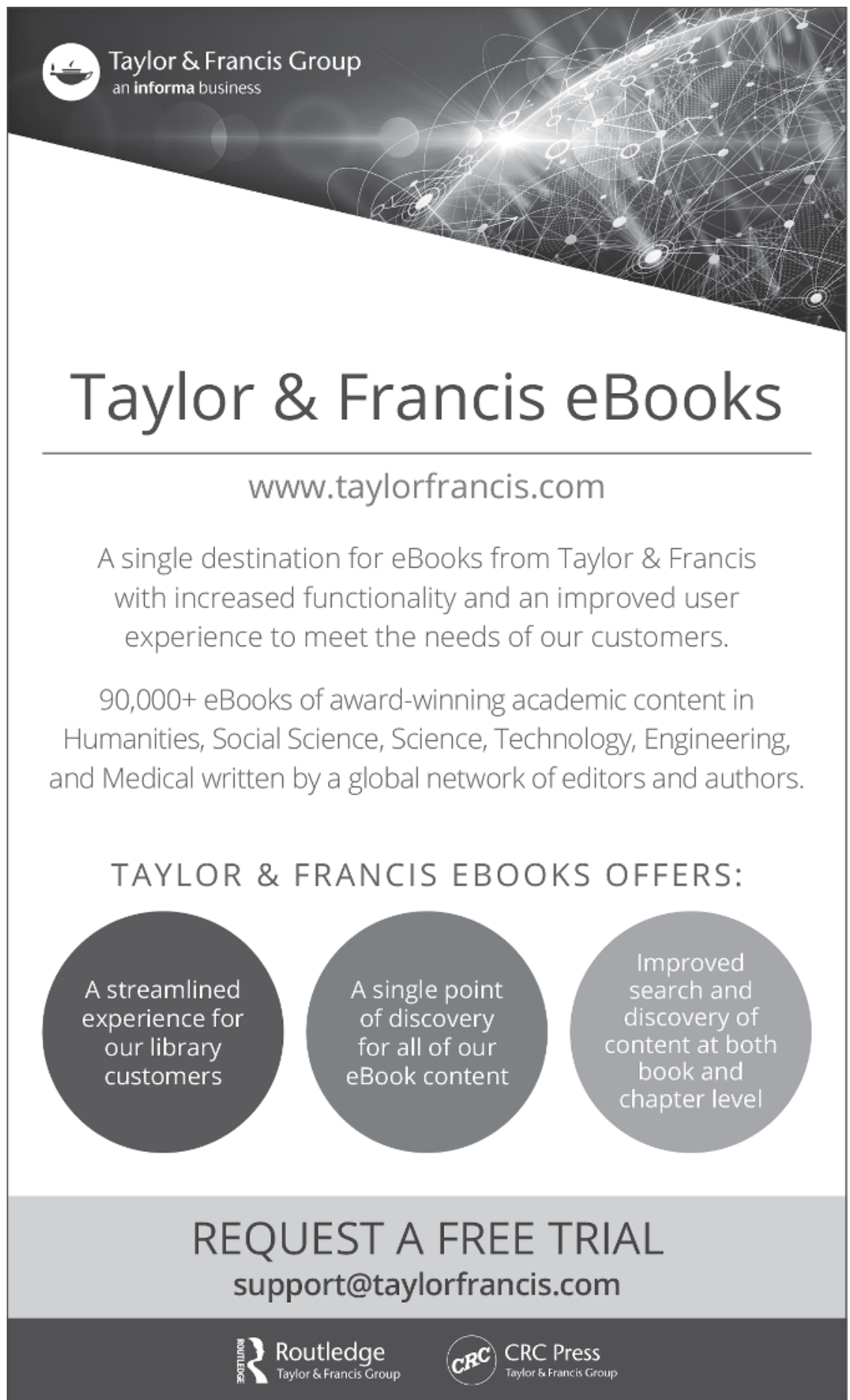

